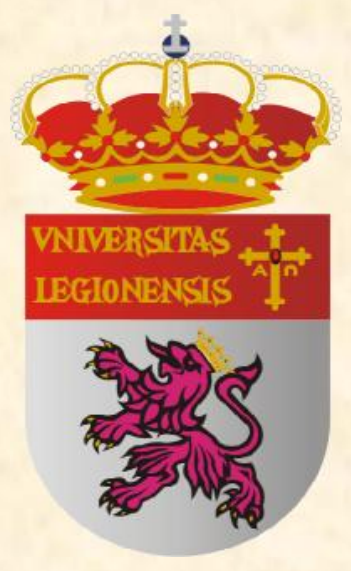

\title{
UNVERSIDADE DE LÉON
}

Departamento de Ciências Biomédicas

Tese de Doutoramento

Perceção e Risco de Exposição Ocupacional ao Xileno e ao Tolueno pelos Trabalhadores da Indústria de Mobiliário

Percepción y Riesgo de Exposición Ocupacional de Xilenos y de Tolueno por los trabajadores de la industria de muebles

Manuel António Lopes da Fonseca Pedroso

\section{León 2015}




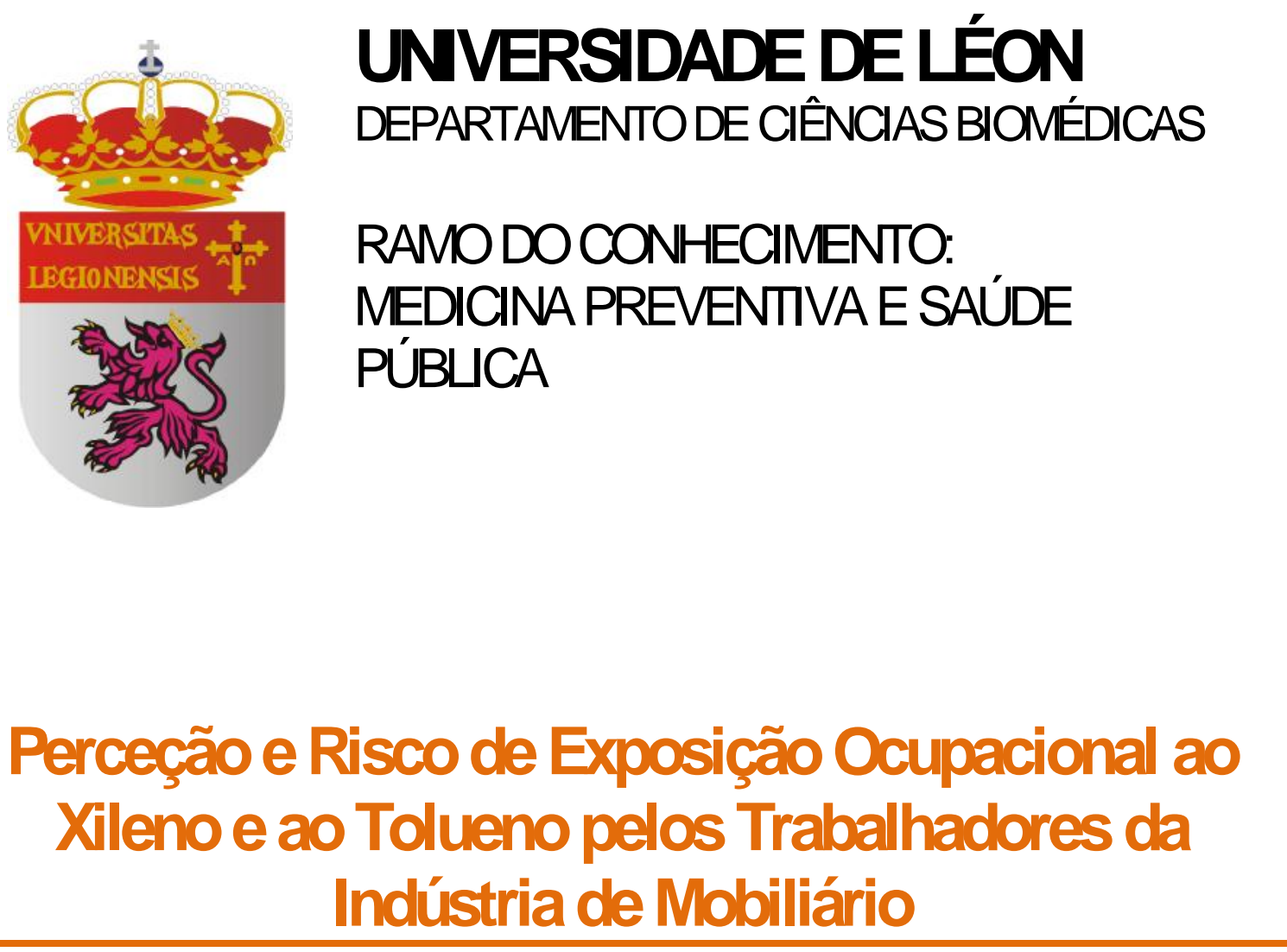

Orientação: Professor Doutor Serafín de Abajo Olea Coorientação: Professora Doutora Mónica Alexandra de Oiveira Dias Teixeira

\section{Manuel António Lopes da Fonseca Pedroso}

León 2015 
Aos meus pais que sempre me deram a educação imprescindível para que pudesse crescer com os valores fundamentais. Pelo apoio incondicional que sempre me disponibilizaram nesta etapa tão exigente da minha vida.

Aos meus avós que sempre se orgulharam dos seus netos.

Aos meus filhos Manuel e Martim que se privaram da minha companhia mas que são a alegria da minha vida.

Esta dedicatória é especialmente para a pessoa que sempre acreditou em mim, nos meus sucessos e sempre orgulhosamente. E que a tragédia da vida me tirou a oportunidade de algum dia poder vir a agradecer, mas, onde quer que esteja ele sabe que os momentos que partilhamos sempre foram de união, amor e partilha. O meu irmão Maurício. 
Compor uma tese de doutoramento é uma combinação de esforços e sentimentos, que só é possível com o envolvimento de muitas pessoas e durante meses, incentivando, orientando, auxiliando, construindo, sem as quais este trabalho eram impossível a sua realização.

A minha gratidão, os meus sentimentos, a minha admiração e o meu mais profundo respeito por todos os que me ajudaram nesta fase difícil mas aliciante da minha vida. Para, os que possibilitaram transformar este sonho numa realidade é com grande alegria, emoção e carinho que vos digo - Muito Obrigada!

Um agradecimento profundo e sincero aos orientadores deste projeto, Serafín de Abajo Olea - Universidade de Léon - e Mónica Alexandra de Oliveira Dias Teixeira - REQUIMTE - ISEP (GRAQ - Grupo de Reação de Análises Químicas) - que me orientaram neste percurso com um trabalho incansável e um apoio científico e humano inimaginável. Foram a minha inspiração e motivação.

Aos meus colegas de doutoramento especialmente ao Fernando Batista e à Marta Vasconcelos pelo apoio e esperança que me deram.

À empresa Hisesa - Higiene, Segurança E Saúde No Trabalho, Lda na pessoa do Eng.․ Carlos Ferreira pela disponibilidade incondicional no empréstimo da bomba de amostragem SKC.

À empresa Monitar, Lda - Engenharia do Ambiente principalmente ao Eng.․ Paulo Pinho, Eng.․ Joao Leite e Eng.‥ Jonnhy Reis por serem tão prestáveis e disponíveis no esclarecimento de todas as dúvidas e pelo empréstimo do calibrador automático de caudal da bomba de amostragem e do porta tubos colorimétricos. 
Agradeço a Cristina Delerue Matos, Coordenadora Científica do Grupo de Reação e Análises Químicas (GRAQ) do Instituto Superior de Engenharia do Porto (ISEP) e a Teresa Oliva Teles, Investigadora do Grupo de Reação de Análises Químicas (GRAQ) do Instituto Superior de Engenharia do Porto (ISEP) o apoio científico e institucional e a oportunidade, que me concederam, de crescimento profissional. Muito obrigada pela prontidão que sempre demonstraram em ajudar-me.

À Maria Ferreira por toda a ajuda, motivação, inspiração e apoio incondicional na realização deste trabalho. És uma força da natureza. Não há palavras que descrevam tanta gratidão.

À Ana Teixeira pela sua sabedoria e pela pronta disponibilidade em ajudar horas intermináveis. És fantástica.

Aos trabalhadores que colaboraram no estudo com sentido de responsabilidade e reconhecimento da importância deste trabalho na melhoria das condições de saúde do ambiente laboral.

À gestão e administração das empresas por abrirem suas portas, disponibilizarem seus trabalhadores, partilharem informação e reconhecerem a importância da melhoria das condições dos locais de trabalho.

À direção da minha entidade patronal, Autoridade para as Condições do Trabalho nas pessoas do Sr. Inspetor Geral Eng.․ Pedro Braz, dos Srs. Subinspetores Dr. António Santos e Dr. Manuel Roxo pelo reconhecimento do valor deste trabalho e assim terem dado parecer positivo à Secretaria de Estado do Ministério da Solidariedade, Emprego e Segurança Social com vista à obtenção da equiparação a bolseiro.

Ao Sr. Secretário de Estado do Emprego Dr. Octávio de Oliveira pelo reconhecimento e despacho da minha equiparação a bolseiro. 
Ao Dr. Pedro Martins e restante equipa de recursos humanos da Autoridade para as Condições do Trabalho pela forma prestável e célere como trataram de todo o processo de equiparação a bolseiro.

Ao meu chefe Dr. João Monteiro pela compreensão e flexibilidade das minhas ausências ao trabalho em regime de equiparação a bolseiro.

A todos os meus colegas de trabalho da Unidade Local de Viseu da Autoridade para as Condições do Trabalho pela compreensão, companheirismo, apoio, motivação e ajuda. O meu agradecimento especial à Emelda, Catarina, Albuquerque e Anabela por toda a ajuda que me deram.

À minha esposa pela minha ausência e muitas vezes foi mãe e pai na educação dos meninos.

À minha família presto-vos a minha sincera homenagem.

Agradeço também a todos aqueles que, não sendo aqui mencionados, contribuíram de forma mais indireta para a realização deste trabalho de investigação.

A todos, o meu pedido de desculpa, pela minha ausência mas principalmente pelo meu mau feitio que migra de dentro de mim até à superfície nos momentos mais difíceis, e foram alguns, muitos até, demasiados!!

A todos muito obrigado!

Penacova, novembro de 2015

Manuel Pedroso 
"Quando corro digo a mim mesmo para pensar num rio. E nuvens. Mas em essência não estou pensando numa coisa. Tudo que faço é continuar correndo no meu próprio vácuo aconchegante, caseiro, meu silêncio nostálgico.

E isso é uma coisa maravilhosa. Digam as pessoas o que disserem."

Haruki Murakami 


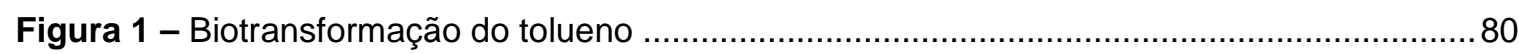

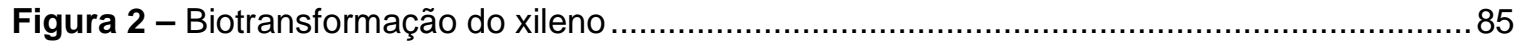

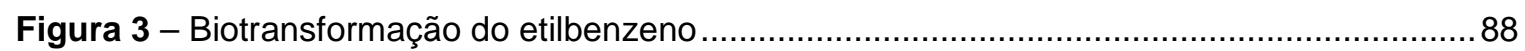

Figura 4 - Aplicação de verniz em cabine de filtros secos …....................................................... 96

Figura 5 - Aplicação de verniz em cabine de filtros secos ..........................................................96

Figura 6 - Aplicação de velatura em cabine de filtros secos ...................................................

Figura 7 - Aplicação de verniz em cabine de cortina de água.................................................97

Figura 8 - Aplicação de verniz em cabine de cortina de água..................................................... 98

Figura 9 - Aplicação de esmalte em cabine de cortina de água................................................98

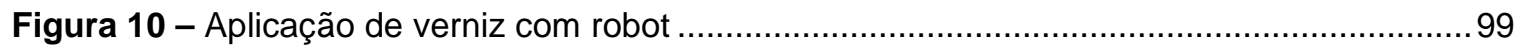

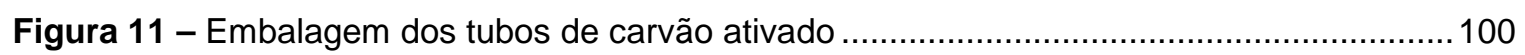

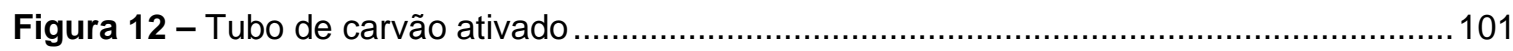

Figura 13 - Tubo de carvão ativado depois de utilizado ....................................................... 101

Figura 14 - Bomba de amostragem e respetivo calibrador digital ........................................... 102

Figura 15 - Número de trabalhadores segundo as habilitações literárias ..................................108

Figura 16 - Conhecimento do risco dos produtos químicos. ................................................111

Figura 17 - Conhecimento dos produtos químicos utilizados................................................. 114

Figura 18 - Comportamentos na manipulação de produtos químicos .......................................117

Figura 19 - Perceção do risco da exposição a tintas/velaturas, vernizes e tapa poros ..............123

Figura 20 - Utilização de equipamentos de proteção individual ............................................... 128

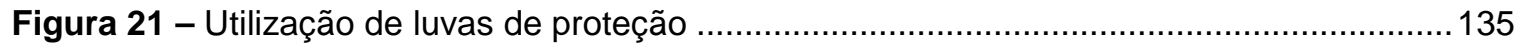

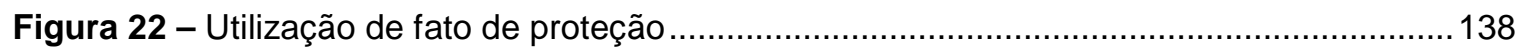

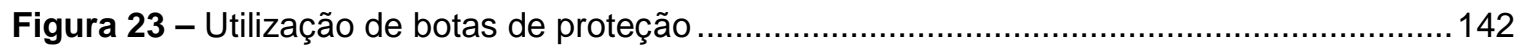

Figura 24 - Utilização de equipamentos de proteção coletiva ................................................. 146

Figura 25 - Efeitos fisiológicos subsequentes à exposição a tintas/velaturas, vernizes e tapa

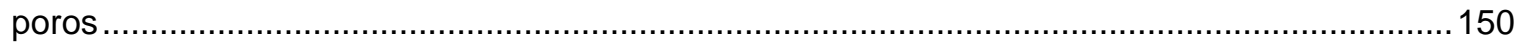

Figura 26 - Interferência do posto de trabalho na exposição ................................................ 158

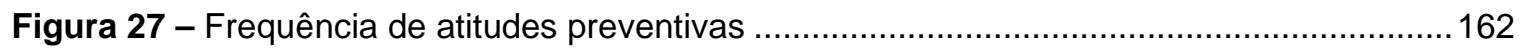

Figura 28 - Número de trabalhadores sobre a formação em combate a incêndios .................... 165 
Figura 29 - Número de trabalhadores sobre a formação dos riscos dos produtos químicos .... 166

Figura 30 - Número de trabalhadores sobre a formação no manuseamento correto dos riscos dos produtos químicos

Figura 31 - Número de trabalhadores sobre a formação em como proceder no caso de derrame dos produtos químicos 168

Figura 32 - Número de trabalhadores sobre a formação em saúde e segurança na aplicação dos produtos químicos. 169

Figura 33 - Antiguidade da formação sobre os riscos laborais no posto de trabalho 170

Figura 34 - Deslocação das concentrações médias ponderadas do tolueno versus valores de referência

Figura 35 - Deslocação das concentrações de curta duração do tolueno, segundo o DL 24/2012

Figura 36 - Deslocação das concentrações médias ponderadas do etilbenzeno versus valores de referência

Figura 37 - Deslocação das concentrações médias ponderadas de isómeros do xileno versus valores de referência

Figura 38 - Deslocação das concentrações de curta duração de isómeros do xileno versus valores de referência.

Figura 39 - Deslocação da média ponderada aplicando o efeito aditivo da exposição aos isómeros do xileno, tolueno e etilbenzeno. 180

Figura 40 - Relação linear entre o etilbenzeno no ar e a soma do ácido mandélico e do ácido fenilglioxílico na urina. 183

Figura 41 - Relação linear entre o xileno no ar e dos ácidos (o, m, p)-metilhipúricos na urina. 183

Figura 42 - Relação linear entre o tolueno no ar e do ácido hipúrico na urina 184

Figura 43 - Relação linear entre o tolueno no ar e o-cresol na urina. 184 


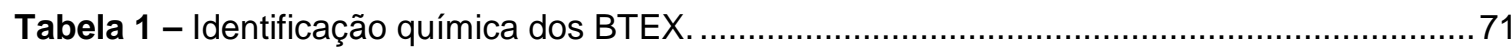

Tabela 2 - Distribuição por sexo dos trabalhadores inquiridos ............................................... 106

Tabela 3 - Distribuição por faixa etária dos trabalhadores inquiridos ...................................... 107

Tabela 4 - Distribuição por habilitações literárias dos trabalhadores inquiridos .........................107

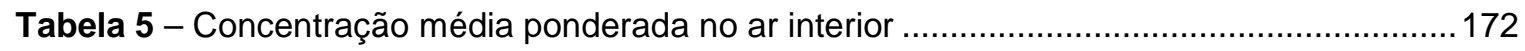

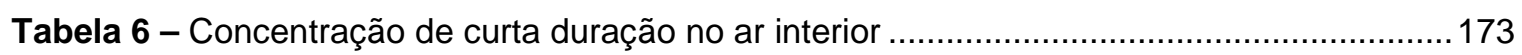

Tabela 7 - Níveis médios dos indicadores biológicos de exposição de Xileno (o-MHA, m-MHA e p-MHA), Etilbenzeno (AM e AFG) e Tolueno (AH e o-cresol) na urina, antes e após a exposição

Tabela 8 - Relação linear entre o xileno, o etilbenzeno e o tolueno no ar e os indicadores biológicos de exposição na urina 182

Tabela 9 - Níveis urinários dos ácidos mandélico, fenilglioxílico, hipúrico e metilhipúricos antes e após a exposição ao etilbenzeno, ao tolueno e ao xileno pelo teste t-Student, com um nível de significância de $5 \%$ 185

Tabela 10 - Níveis urinários de o-cresol antes e após a exposição ao tolueno pelo teste tStudent, com um nível de significância de 5\% 186

Tabela 11 - Respostas Sobre a Classificação do Risco associado às tintas/velaturas da madeira .227

Tabela 12 - Respostas Sobre a Classificação do Risco associado ao verniz ............................227

Tabela 13 - Respostas Sobre a Classificação do Risco associado ao tapa poros......................228

Tabela 14 - Respostas Sobre a Classificação do Risco associado ao xileno .............................228

Tabela 15 - Respostas Sobre a Classificação do Risco associado ao tolueno ...........................222

Tabela 16 - Respostas Sobre a Classificação do Risco associado ao diluente ..........................229

Tabela 17 - Respostas Sobre a Afirmação: "Sei distinguir as tintas/velaturas, vernizes e tapa poros".

Tabela 18 - Respostas Sobre a Afirmação: "Já li as fichas de dados de segurança dos produtos químicos que utilizo". 230

Tabela 19 - Respostas Sobre a Afirmação: "O xileno e o tolueno são substâncias químicas que compõem as tintas/velaturas, vernizes e tapa poros" 231

Tabela 20 - Respostas Sobre a Afirmação: "As tintas/velaturas, vernizes e tapa poros que utilizo são de base solvente"

Tabela 21 - Respostas Sobre a Afirmação: "As tintas/velaturas, vernizes e tapa poros que utilizo de base solvente têm os mesmos riscos se forem de base aquosa" 232 
Tabela 22 - Respostas Sobre a Classificação do Risco associado à exposição às tintas/velaturas 233

Tabela 23 - Respostas Sobre a Classificação do Risco associado à exposição ao tapa poros 233

Tabela 24 - Respostas Sobre a Classificação do Risco associado à exposição aos vernizes.. 234

Tabela 25 - Respostas Sobre a Classificação do Risco associado à exposição aos diluentes. 234

Tabela 26 - Respostas Sobre a Classificação do Risco associado à exposição a lubrificantes 235

Tabela 27 - Respostas Sobre a Classificação do Risco associado à aplicação das tintas/velaturas, tapa poros e vernizes 235

Tabela 28 - Respostas Sobre a Classificação do Risco associado à diluição das tintas/velaturas, tapa poros e vernizes.

Tabela 29 - Respostas Sobre a Classificação do Risco associado à aplicação das tintas/velaturas, tapa poros e vernizes com as cabines desligadas .......................................... 236

Tabela 30 - Respostas Sobre a Classificação do Risco associado à aplicação das tintas/velaturas, tapa poros e vernizes fora das cabines

Tabela 31 - Respostas Sobre a Classificação do Risco associado à proximidade da estufa de secagem

Tabela 32 - Respostas Sobre a Classificação do Risco associado ao manuseamento tintas/velaturas, tapa poros e vernizes sem luvas 238

Tabela 33 - Respostas Sobre a Classificação do Risco associado ao manuseamento tintas/velaturas, tapa poros e vernizes sem máscara. 238

Tabela 34 - Respostas Sobre a Classificação do Risco associado a não usar equipamentos de proteção individual (EPI's) na aplicação das tintas/velaturas, tapa poros e vernizes. 239

Tabela 35 - Respostas Sobre a Afirmação: "A exposição aos gases/vapores das tintas/velaturas pode ser perigosa"

Tabela 36 - Respostas Sobre a Afirmação: "A exposição aos gases/vapores dos vernizes pode ser perigosa"

Tabela 37 - Respostas Sobre a Afirmação: "A exposição aos gases/vapores do tapa poros pode ser perigosa"

Tabela 38 - Respostas Sobre a Afirmação: "A exposição aos gases/vapores das tintas/velaturas é perigosa"

Tabela 39 - Respostas Sobre a Afirmação: "A exposição aos gases/vapores dos vernizes é perigosa"

Tabela 40 - Respostas Sobre a Afirmação: "A exposição aos gases/vapores do tapa poros é perigosa".

Tabela 41 - Respostas Sobre a Afirmação: "Não existe risco se a exposição for por pouco tempo" 243 
Tabela 42 - Respostas Sobre a Afirmação: "A exposição a estes produtos pode provocar doenças".

Tabela 43 - Respostas Sobre a Afirmação: "A exposição a estes produtos não provoca danos para a saúde".

Tabela 44 - Respostas Sobre a Afirmação: "Os meus colegas acham que não é necessário usar máscara na manipulação de tintas/velaturas"

Tabela 45 - Respostas Sobre a Afirmação: "Os meus colegas acham que não é necessário usar máscara na manipulação do tapa poros".

Tabela 46 - Respostas Sobre a Afirmação: "Os meus colegas acham que não é necessário usar máscara na manipulação de vernizes". 246

Tabela 47 - Respostas Sobre a Afirmação: "Deram-me máscara de proteção respiratória para a manipulação de tintas/velaturas, vernizes e tapa poros"

Tabela 48 - Respostas Sobre a Afirmação: "Penso que as máscaras que me deram são as mais adequadas".

Tabela 49 - Respostas Sobre a Afirmação: "Sei utilizar a máscara corretamente". 248

Tabela 50 - Respostas Sobre a Afirmação: "As máscaras para gases e vapores são as mais adequadas para a manipulação das tintas/velaturas, vernizes e tapa poros".

Tabela 51 - Respostas Sobre a Afirmação: "Sei quando tenho de substituir os filtros da minha máscara".

Tabela 52 - Respostas Sobre a Afirmação: "Sei como fazer a manutenção/limpeza da minha máscara"..... 249

Tabela 53 - Respostas Sobre a Afirmação: "Por vezes a minha máscara fica estragada" 250

Tabela 54 - Respostas Sobre a Afirmação: "Quando a minha máscara está danificada substituoa imediatamente". 250

Tabela 55 - Respostas Sobre a Afirmação: "Preciso saber mais para utilizar corretamente a máscara" 251

Tabela 56 - Respostas Sobre a Afirmação: "Quando a minha máscara está estragada espero que termine o trabalho para a substituir".

Tabela 57 - Respostas Sobre a Afirmação: "Sei quantas vezes posso usar o filtro da minha máscara". 252

Tabela 58 - Respostas Sobre a Afirmação: "Utilizo a máscara que estiver disponível” 252

Tabela 59 - Respostas Sobre a Afirmação: "Sei distinguir os vários tipos de máscaras de proteção".

Tabela 60 - Respostas Sobre a Afirmação: "Preciso aprender mais para escolher a máscara de proteção mais eficaz"

Tabela 61 - Respostas Sobre a Afirmação: "Gosto do cheiro das tintas/velaturas" 254

Tabela 62 - Respostas Sobre a Afirmação: "Gosto do cheiro do tapa poros". .254 
Tabela 63 - Respostas Sobre a Afirmação: "Gosto do cheiro dos vernizes" 255

Tabela 64 - Respostas Sobre a Afirmação: "Deram-me luvas de proteção para a manipulação de tintas/velaturas, vernizes e tapa poros"

Tabela 65 - Respostas Sobre a Afirmação: "Uso as luvas para a manipulação de tintas/velaturas, vernizes e tapa poros"

Tabela 66 - Respostas Sobre a Afirmação: "O contato das tintas/velaturas, vernizes e tapa poros com a pele é perigoso".

Tabela 67 - Respostas Sobre a Afirmação: "Penso que as luvas que me deram são as mais adequadas"

Tabela 68 - Respostas Sobre a Afirmação: "Sei utilizar as luvas corretamente". 257

Tabela 69 - Respostas Sobre a Afirmação: "Quando as luvas estão danificadas substituo-as imediatamente"

Tabela 70 - Respostas Sobre a Afirmação: "Quando preciso tenho sempre disponível luvas de substituição".

Tabela 71 - Respostas Sobre a Afirmação: "Uso sempre as luvas". 259

Tabela 72 - Respostas Sobre a Afirmação: "Deram-me fato de proteção para a manipulação de tintas/velaturas, vernizes e tapa poros"

Tabela 73 - Respostas Sobre a Afirmação: "Penso que o fato que deram para a manipulação de tintas/velaturas, vernizes e tapa poros é o mais adequado"

Tabela 74 - Respostas Sobre a Afirmação: "O fato tem o tamanho adequado" 260

Tabela 75 - Respostas Sobre a Afirmação: "Sei utilizar o fato corretamente" 261

Tabela 76 - Respostas Sobre a Afirmação: "Quando o fato está estragado substituo-o imediatamente" 261

Tabela 77 - Respostas Sobre a Afirmação: "Quando preciso tenho sempre disponível um fato de substituição". 262

Tabela 78 - Respostas Sobre a Afirmação: "No verão não uso fato de proteção" 262

Tabela 79 - Respostas Sobre a Afirmação: "Deram-me botas para a manipulação de tintas/velaturas, vernizes e tapa poros" 263

Tabela 80 - Respostas Sobre a Afirmação: "Penso que as botas que deram para a manipulação de tintas/velaturas, vernizes e tapa poros são as mais adequadas"..... 263

Tabela 81 - Respostas Sobre a Afirmação: "As botas têm o tamanho adequado". 264

Tabela 82 - Respostas Sobre a Afirmação: "Quando as botas estão estragadas substituo-as imediatamente"

Tabela 83 - Respostas Sobre a Afirmação: "Quando preciso tenho sempre disponível umas botas de substituição" 265

Tabela 84 - Respostas Sobre a Afirmação: "Uso sempre botas" 265 
Tabela 85 - Respostas Sobre a Afirmação: "Não é necessário o funcionamento das cabines desde que utilize a máscara de proteção respiratória para gases" 266

Tabela 86 - Respostas Sobre a Afirmação: "Ligo sempre as cabines quando aplico as tintas/velaturas, vernizes e tapa poros". 266

Tabela 87 - Respostas Sobre a Afirmação: "Não é necessário o funcionamento dos equipamentos de extração desde que utilize a máscara de proteção respiratória para gases"..267

Tabela 88 - Respostas Sobre a Afirmação: "No inverno às vezes não ligo as cabines". 267

Tabela 89 - Respostas Sobre a Afirmação: "Quando está frio não ligo os equipamentos de extração". 268

Tabela 90 - Respostas Sobre a Afirmação: "A exposição às tintas/velaturas, vernizes e tapa poros provoca-me irritação no nariz e garganta"

Tabela 91 - Respostas Sobre a Afirmação: "A exposição às tintas/velaturas, vernizes e tapa poros provoca-me irritação dos olhos"

Tabela 92 - Respostas Sobre a Afirmação: "Durante o trabalho com as tintas/velaturas, vernizes e tapa poros já tive irritação nos olhos".

Tabela 93 - Respostas Sobre a Afirmação: "Durante o trabalho com as tintas/velaturas, vernizes e tapa poros já tive irritação no nariz e garganta".

Tabela 94 - Respostas Sobre a Afirmação: "A exposição às tintas/velaturas, vernizes e tapa poros provoca-me dores de cabeça".

Tabela 95 - Respostas Sobre a Afirmação: "Tenho frequentemente dores de cabeça" 272

Tabela 96 - Respostas Sobre a Afirmação: "Antes de trabalhar na empresa de mobiliário não tinha dores de cabeça"

Tabela 97 - Respostas Sobre a Afirmação: "Antes de trabalhar na empresa de mobiliário tinha menos dores de cabeça". 273

Tabela 98 - Respostas Sobre a Afirmação: "A exposição às tintas/velaturas, vernizes e tapa poros causa-me sonolência" 273

Tabela 99 - Respostas Sobre a Afirmação: "Quando estou exposto às tintas/velaturas, vernizes e tapa poros perco o apetite".

Tabela 100 - Respostas Sobre a Afirmação: "Desde que trabalho com as tintas/velaturas, vernizes e tapa poros tenho maior dificuldade em ouvir".

Tabela 101 - Respostas Sobre a Afirmação: "Há muito ruído no meu posto de trabalho"..... 275

Tabela 102 - Respostas Sobre a Afirmação: "Por vezes tenho vómitos no trabalho" 275

Tabela 103 - Respostas Sobre a Afirmação: "A exposição às tintas/velaturas, vernizes e tapa poros causa-me vómitos".

Tabela 104 - Respostas Sobre a Afirmação: "Já tive vertigens/tonturas no meu posto de trabalho". 
Tabela 105 - Respostas Sobre a Afirmação: "A exposição às tintas/velaturas, vernizes e tapa poros causa-me vertigens/tonturas"

Tabela 106 - Respostas Sobre a Afirmação: "Quando não utilizo luvas e estou a utilizar as tintas/velaturas, vernizes e tapa poros fico com a pele seca e irritada".

Tabela 107 - Respostas Sobre a Afirmação: "A minha perceção/sensibilidade aos cheiros diminuiu desde que fiquei exposto às tintas/velaturas, vernizes e tapa poros".

Tabela 108 - Respostas Sobre a Afirmação: "Ritmo de trabalho muito intenso" 279

Tabela 109 - Respostas Sobre a Afirmação: "Por vezes noto muito cheiro aos produtos químicos".

Tabela 110 - Respostas Sobre a Afirmação: "Às vezes os recipientes vazios das tintas/velaturas, vernizes e tapa poros não são retirados imediatamente dos postos de trabalho". 280

Tabela 111 - Respostas Sobre a Afirmação: "Estou satisfeito com o funcionamento das cabines de aspiração"

Tabela 112 - Respostas Sobre a Afirmação: "Acho que as cabines de aspiração têm a manutenção adequada"

Tabela 113 - Respostas Sobre a Afirmação: "É possível diminuir a exposição às tintas/velaturas, vernizes e tapa poros". 282

Tabela 114 - Respostas Sobre a Afirmação: "É possível diminuir a exposição aos cheiros das tintas/velaturas, vernizes e tapa poros"

Tabela 115 - Respostas Sobre a Afirmação: "Existe preocupação da empresa em diminuir a exposição às tintas/velaturas, vernizes e tapa poros". 283

Tabela 116 - Respostas Sobre a Afirmação: "Não cumprir as regras de segurança" 284

Tabela 117 - Respostas Sobre a Afirmação: "Executar as atividades de acordo com as instruções de trabalho". 285

Tabela 118 - Respostas Sobre a Afirmação: "Executar as atividades de acordo com o que a empresa me ensinou"

Tabela 119 - Respostas Sobre a Afirmação: "Usar sempre luvas na manipulação das tintas/velaturas, vernizes e tapa poros" 286

Tabela 120 - Respostas Sobre a Afirmação: "Usar sempre avental na manipulação das tintas/velaturas, vernizes e tapa poros" 286

Tabela 121 - Respostas Sobre a Afirmação: "Usar sempre fato de proteção na manipulação das tintas/velaturas, vernizes e tapa poros" 287

Tabela 122 - Respostas Sobre a Afirmação: "Usar sempre máscara de proteção na manipulação das tintas/velaturas, vernizes e tapa poros"

Tabela 123 - Respostas Sobre a Afirmação: "Já tive formação de combate a incêndios" 288

Tabela 124 - Respostas Sobre a Afirmação: "Já tive formação sobre os riscos dos produtos químicos". 
Índice de Tabelas

Tabela 125 - Respostas Sobre a Afirmação: “Já tive formação acerca do manuseamento correto

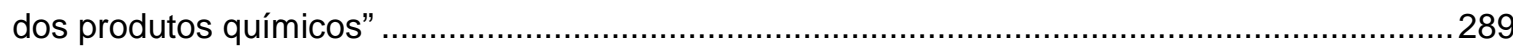

Tabela 126 - Respostas Sobre a Afirmação: "Já tive formação de como proceder no caso de derrame dos produtos químicos". 289

Tabela 127 - Respostas Sobre a Afirmação: “Já tive formação sobre saúde e segurança na aplicação dos produtos químicos". 290

Tabela 128 - Respostas Sobre a Afirmação: "A última vez que tive formação sobre riscos laborais no meu posto de trabalho" 290 


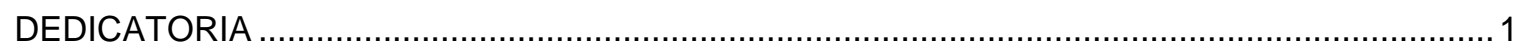

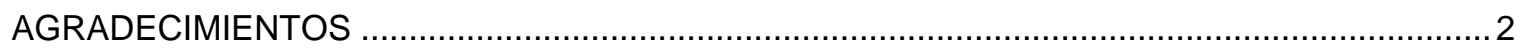

EPÍGRAFE

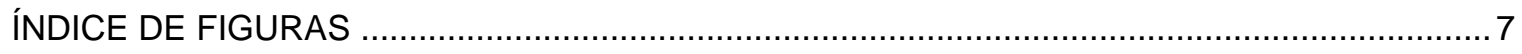

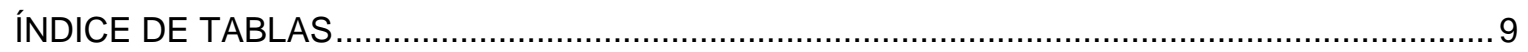

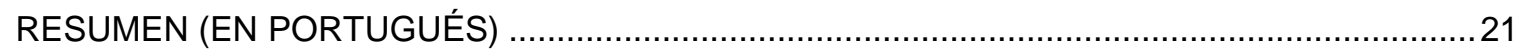

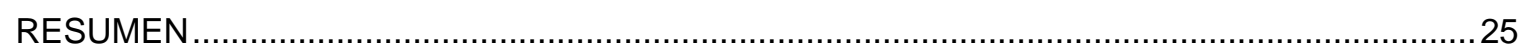

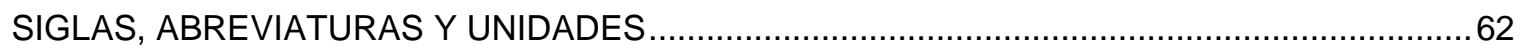

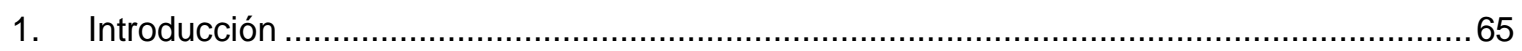

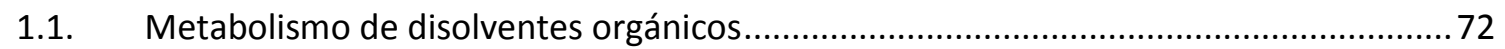

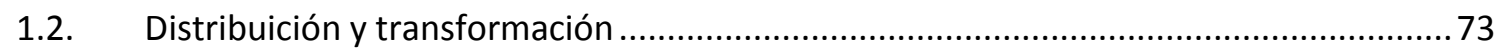

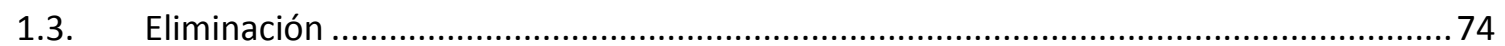

1.4. Neurotoxicidad, carcinogenicidad y las manifestaciones en la salud ...........................74

1.5. Características toxicocinéticas y dinámicas del tolueno ................................................ 76

1.6. Características toxicocinéticas y dinámicas del xileno .................................................... 81

1.7. Características toxicocinéticas y dinámicas del etilbenceno ...........................................86

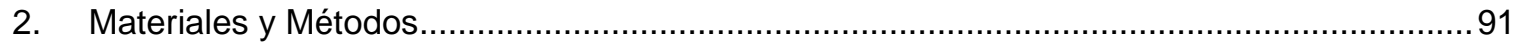

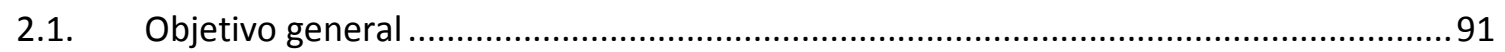

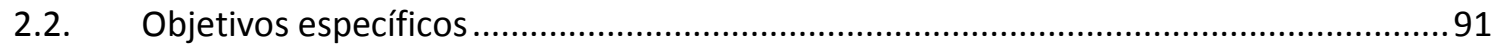

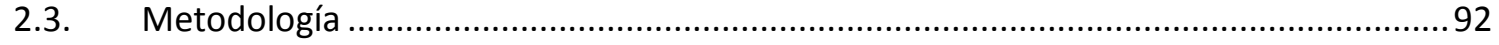

2.4. Recopilación de datos para la caracterización de la muestra .......................................92

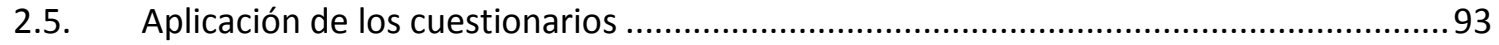

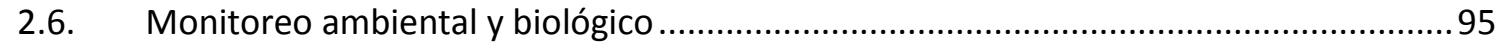

2.6.1. Muestreo y determinación analítica ...................................................................95

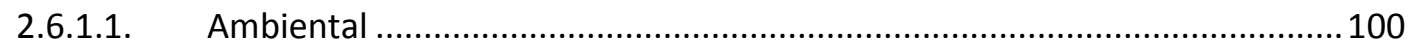

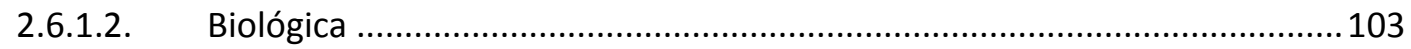

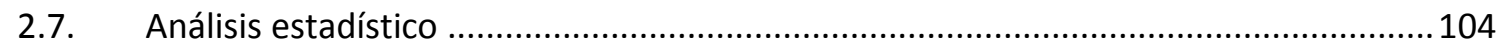

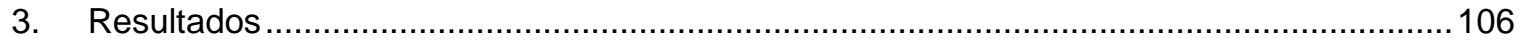

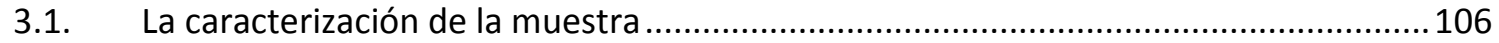

3.2. Resultados de los cuestionarios ............................................................................ 108 


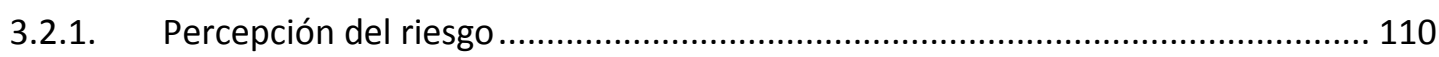

3.2.1.1. Conocimiento del riesgo de los productos químicos ................................ 110

3.2.1.2. Conocimiento del riesgo de los productos utilizados ................................ 113

3.2.1.3. Comportamientos en la manipulación de productos químicos.................... 116

3.2.1.4. Percepción del riesgo de la exposición a las tintas, barnices y tapaporos .. 122

3.2.1.5. Uso de equipos de protección personal ................................................. 127

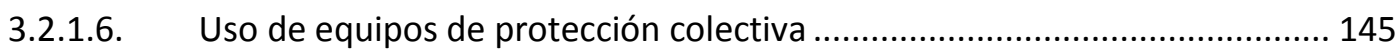

3.2.1.7. Efectos fisiológicos posteriores de la exposición a las tintas, barnices y

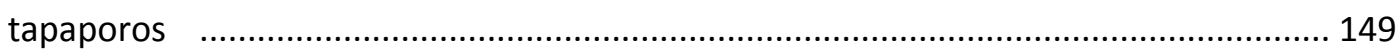

3.2.1.8. Interferencia del puesto de trabajo en la exposición .................................. 157

3.2.1.9. Frecuencia de las medidas preventivas .................................................... 161

3.2.1.10. Formación profesional proporcionada por las empresas ............................ 165

3.3. Monitoreo del aire interior en las áreas de aplicación de productos químicos ........... 171

3.3.1. Niveles ambientales de tolueno, etilbenceno y xileno ........................................ 171

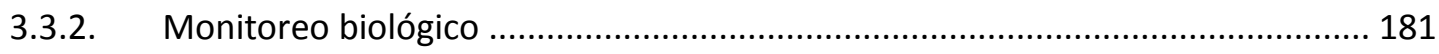

3.3.2.1. Niveles en la orina de ácidos metil-hipúricos (AMH), ácido mandélico (AM), ácido fenilglioxílico (AFG), ácido hipúrico (AH) e o-cresol ............................................. 181

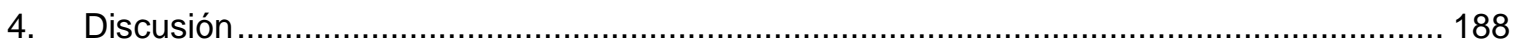

4.1. Análisis de la percepción y riesgo de exposición ........................................................ 188

4.2. Análisis de los monitoreos ambientales del aire en interiores ................................... 191

4.3. Análisis del monitoreo de los indicadores biológicos de exposición en la orina.......... 195

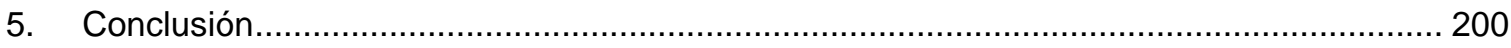

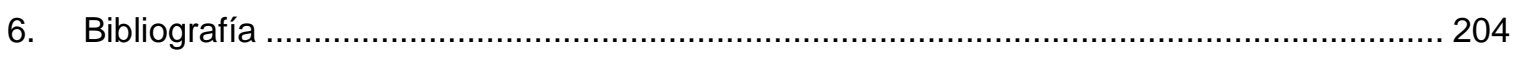

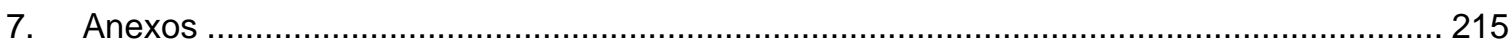

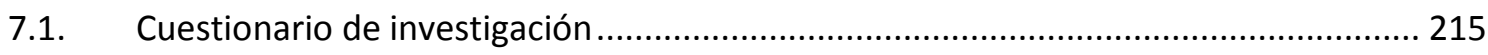

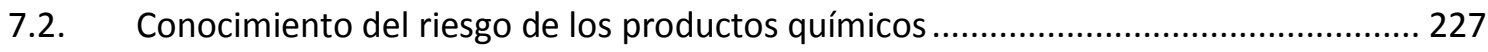

7.3. Conocimiento del riesgo de los productos utilizados ................................................ 230

7.4. Comportamientos en la manipulación de productos químicos .................................... 233

7.5. Percepción del riesgo de la exposición a las tintas, barnices y tapaporos ....................2 240

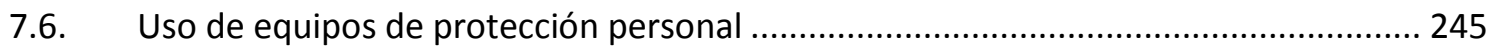

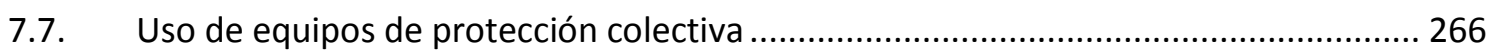


Índice General

7.8. Efectos fisiológicos posteriores de la exposición a las tintas, barnices y tapaporos.... 269

7.9. Interferencia del puesto de trabajo en la exposición.....................................................279

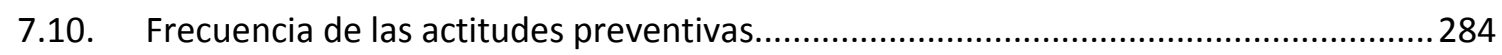

7.11. Formación en la materia de salud y seguridad en el trabajo .......................................28 
A saúde e a segurança no trabalho são bens alienáveis e que devemos preservar a todo o custo. Trabalha-se para viver não para morrer!

Se hoje em dia há alguma perceção dos riscos ocupacionais que podem colocar em causa a segurança, do ponto de vista dos riscos associados à saúde esta perceção ainda é bastante deficitária. O facto dos efeitos produzidos no organismo derivado da exposição às substâncias químicas, na sua esmagadora maioria, só surgirem após anos de exposição, traduz-se numa noção errada de ambiente salubre, por parte dos trabalhadores.

Para tentar contornar esta falta de consciência dos riscos é fundamental a realização de investigações em contexto real de trabalho, por forma, a ter resultados concretos e objetivos dos níveis de perceção ao risco e da exposição as substâncias químicas no dia-a-dia do ambiente laboral.

Após análise dos locais de trabalho e estudo das fichas de dados de segurança dos produtos químicos utilizados nas empresas de mobiliário, concluise que as tintas/velaturas, vernizes e tapa poros são constituídas essencialmente por xileno e tolueno.

O estudo da perceção e risco de exposição ocupacional ao xileno, tolueno e etilbenzeno pelos trabalhadores das fábricas de mobiliário dos distritos de Aveiro, Coimbra e Viseu, pretende avaliar separadamente o risco percebido e o risco real de exposição a estas substâncias químicas no ambiente laboral.

Apoiado numa revisão bibliográfica, desenvolveu-se um questionário para avaliação das variáveis de natureza essencialmente qualitativa, nomeadamente, a perceção individual do risco, a perceção do conhecimento dos produtos químicos, a cultura de segurança e o comportamento de risco, a utilização de equipamentos de proteção coletiva e individual, a perceção dos efeitos da exposição aos produtos químicos, e a formação em matérias de saúde e segurança no trabalho. O estudo descritivo transversal foi realizado em abril e 
maio de 2014 aos trabalhadores das fábricas de mobiliário, com uma amostragem de 142 inquiridos.

O risco real de exposição ocupacional ao xileno, tolueno e etilbenzeno foi estabelecido após a análise quantitativa dos dados obtidos pela avaliação da qualidade do ar (monitorização no ar interior de xileno (isómeros), tolueno e etilbenzeno, e análise dos índices biológicos de exposição ocupacional aos xilenos (ácidos o-, m- e p- metil-hipúricos), tolueno (ácido hipúrico/o - Cresol) etilbenzeno (ácido mandélico e ácido fenilglioxílico).

A análise estatística dos resultados obtidos aponta que a perceção individual do risco é uma componente crítica do comportamento dos trabalhadores.

Constatou-se que os trabalhadores desconhecem que as tintas/velaturas, vernizes e tapa poros são constituídos por xileno e tolueno e desconhecem também os riscos associados à exposição a estas substâncias.

As respostas aos questionários foram reveladoras de comportamentos inadequados, nomeadamente, a falta de manutenção das cabines de aspiração e a falta de utilização de equipamentos de proteção individual apropriados. Ao nível da sintomatologia esta também foi reveladora de uma exposição excessiva aos produtos químicos.

A caracterização da exposição pessoal diária às substâncias estudadas revelou-se de muito risco, uma vez que, a maioria dos valores obtidos, quer nos parâmetros ambientais monitorizados quer nos índices biológicos, foram superiores aos limites legais e normativos.

O conhecimento do risco deverá integrar o planeamento, 0 desenvolvimento e a implementação de programas de formação continua aos trabalhadores. A monitorização dos parâmetros ambientais e biológicos revelouse preciosa e fundamental, para que seja possível obter o conhecimento real da entrada no organismo das substâncias estudadas. Assim, as empresas ficam com todo o conhecimento necessário para estabelecerem as medidas de 
prevenção e/ou proteção coletivas e individuais específicas para o controlo deste tipo de risco. Estes enfoques servirão como paradigma no progresso da ciência na área da Saúde e Segurança no Trabalho.

Palavras-Chave: Risco, Xileno, Tolueno, Etilbenzeno, Tintas, Velaturas, Vernizes, Tapa Poros, Perceção, Saúde, Segurança, Sintomatologia, Cabines de Aspiração. 


\section{Introducción}

El Programa Internacional de Seguridad de las Sustancias Químicas establecido por la Organización Mundial de la Salud (OMS), la Organización de las Naciones Unidas (ONU) y la Organización Internacional de Trabajo (OIT), considera un alrededor de 100 mil el número de sustancias químicas puras existentes y un 4 millones de compuestos de uso comercial (IPCS - International Programme on Chemical Safety, 1999).

Las sustancias químicas existentes en el entorno laboral ocupan el más extendido factor de riesgo profesional entre muchos factores que afectan a la salud humana (Prista, J., Uva, A.S., 2002).

En los últimos anos, con el avance científico en el área de la genética se han abierto nuevos horizontes y eso ha posibilitado la utilización de estos estudios para evaluar los daños y la susceptibilidad de los trabajadores a los agentes químicos.

La atención a los efectos de los agentes químicos alergénicos, con interferencia endócrina, carcinógenos, mutagénicos y teratogénicos cuyas respuestas siguen diferentes patrones de la curva dosis-respuesta del tipo determinista ha aumentado.

En los lugares de trabajo de las empresas tecnológicamente avanzadas, por lo general los entornos ocupacionales y las exposiciones a los agentes químicos son controlados. Esta situación de modo global fue el resultado de la democratización de las informaciones sobre los riesgos químicos, de la sensibilidad de los empleadores, de la evolución tecnológica, de la información de trabajadores, de las acciones de los órganos de la fiscalización, de la evolución legislativa, de la exigencia del comercio y de la competencia, de la protección del medio ambiente, del desempeño responsable de los profesionales de la seguridad y de la sanidad y de la propia movilización de la sociedad.

Por otra parte, el incremento de la complexidad de los productos químicos, en gran parte debido a las exigencias y las preferencias comerciales, 
ha provocado un incremento del número de personas con exposiciones simultáneas a varios agentes químicos procedentes de diversas fuentes que, aisladas o en interacción, han creado nuevas y crecientes situaciones de riesgo. A estos factores se puede añadir una línea de desarrollo tecnológico que es la utilización de substancias a nivel de la nanotecnología.

Por eso, es fundamental que se conozcan todos los factores que de alguna manera puedan influir en la protección de la salud dos trabajadores. Entre ellos, se destacan los efectos adversos de las sustancias utilizadas, el resultado de la evaluación y las medidas de control adoptadas, el monitoreo biológico que reta estimar el riesgo ocupacional y la adopción de medidas efectivas para proteger la salud de las personas expuestas.

La mayoría de las personas pasa cerca del $90 \%$ de su tiempo en espacios interiores, donde innúmeros peligros pueden dar lugar a riesgos para la salud, reduciendo así su calidad de vida. El tema de la calidad del aire ha ganado expresión, ya que muchas de las quejas de los ocupantes se atribuyen a este hecho. Una buena calidad del aire interior es considerada como uno de los parámetros que más contribuye para la productividad, la comodidad, la salud y bienestar (Campos \& Santos, 2010).

Se puede definir la Higiene Industrial como una técnica de actuación en materia de contaminantes del medio ambiente, derivados del trabajo, con el objetivo de prevenir las enfermedades profesionales de los individuos expuestos a ellos (Miguel, AS., 2006). 
El aire puro está compuesto por 78,08\% de nitrógeno, 20,94\% de oxígeno, 0,93\% de argón, $0,03 \%$ de dióxido de carbono, 0,00005\% de hidrógeno y gases nobles. El aire está contaminado cuando contiene sustancias extrañas a su composición normal, o incluso cuando se presenta con cambios cuantitativos, por la presencia de uno o más componentes superiores o inferiores a las normales (Miguel, AS, 2006).

De acuerdo con la ASHRAE (American Society of Heating, Refrigerating, and Air-Conditioning Engineers) la calidad del aire puede ser aceptable si:

- en el aire interior no hay concentraciones peligrosas de contaminantes;

- más del $80 \%$ de las personas expuestas no tienen aversión a la condiciones de calidad del aire interior (Campos \& Santos, 2010).

Gioda y Aquino Neto (2003a) apuntan para algunas fuentes internas que emiten contaminantes del aire: máquinas de oficinas (fotocopiadoras), materiales de construcción (tintas y barnices) y de decoración (alfombras y adhesivos). Segundo Javier et al., (2003), esas fuentes pueden emitir hacia 900 compuestos diferentes para el aire del medio ambiente.

Entre estos compuestos están los derivados de petróleo, denominados de hidrocarburos. Estos son moléculas orgánicas compuestas de carbono e hidrógeno, que a través de derivaciones sencillas de su estructura molecular, forman una variedad de compuestos (Baird, 1995). Los hidrocarburos forman parte del grupo principal de compuestos orgánicos volátiles en la atmósfera (Kalabokas, et al., 2001), y sus concentraciones en entornos interiores son dos veces más altas que en entornos externos (Godish, 1991).

Las principales fuentes de hidrocarburos aromáticos son la destilación de hulla y un sin número de procesos petroquímicos, en particular la destilación catalítica, la destilación de petróleo crudo y la alquilación de los hidrocarburos aromáticos de las series inferiores (Stellman, et al., 2001).

En muchos países industrializados, la exposición a los hidrocarburos aromáticos fue identificada como un problema de salud pública debido a su amplia utilización en la industria, las formas inadecuadas de manipulación y 
disposición de estos productos, que generan contaminación del medio ambiente, del trabajo y efectos sobre la salud (Torres, et al., 2006).

La exposición a los hidrocarburos aromáticos utilizados en numerosos procesos industriales se considera un riesgo ocupacional para millones de trabajadores esparcidos alrededor del mundo (Rodríguez, 2003).

El término compuesto orgánico volátil (COV) se utiliza a menudo como sinónimo de disolvente orgánico y es definido por diferentes metodologías de acuerdo con el país o la organización (Dewulf, et al., 2002).

En muchos casos, las concentraciones de COV en ambientes interiores son más pequeñas que los límites ocupacionales permisibles, de acuerdo con Godish (1991). En los niveles de alrededor de 0,3 mg/m³ los COV combinados con condiciones inadecuadas de confort provocadas por temperatura y humedad elevadas pueden provocar irritación y malestar, (Carmo y Prado, 1999). Estos síntomas son causados por el desarrollo de sensibilidad provocada por las continuas exposiciones al COV (Becher, et al., 1996). El COV está asociado también a la presencia de olores (Belli, Fo․ y De Melo, 1998), donde los microorganismos son los principales responsables por la producción de sustancias aromáticas (Sunesson, et al., 1995). Además de la hipersensibilidad, los hidrocarburos insaturados y/o aromáticos poseen gran potencial mutagénico (Brickus y Aquino Neto, 1999).

La acción de tóxico en el cuerpo humano puede manifestarse como una enfermedad clínica, trastornos funcionales o cambios biológicos críticos, es decir, predictivas de una alteración de la salud si continúan o son recurrentes.

La evaluación de la eficacia de las medidas de prevención consiste en tres metodologías de vigilancia: 
- Determinar la concentración de productos químicos en el aire de los puestos de trabajo de los trabajadores expuestos (vigilancia 0 monitoreo del ambiente);

- Evaluar mediante análisis biológicas, (sangre, orina, aire espirado, etc.) hechas a los trabajadores expuestos, si la intensidad de la exposición (dosis interna) no es excesiva (vigilancia o monitoreo biológico de la exposición);

- Detectar lesiones bioquímicas o fisiológicas tempranas, si posible en un estado todavía reversible (vigilancia del estado de salud).

El análisis del riesgo de la exposición a agentes químicos asociada al desarrollo de actividades profesionales incluye la determinación de la concentración de aquellos agentes en el aire de los lugares de trabajo. Esta concentración, cuando representativa de la exposición profesional enfocada, se compara con los valores de referencia que representan umbrales de exposiciones correspondientes a niveles de riesgo aceptables.

Para entender mejor los conceptos subyacentes a las mediciones de la calidad del aire interior hechos, es importante tener en cuenta algunos conceptos tales como: valores límite de exposiciones y nivel de acción.

Estos valores de referencia, denominados de "valores límite de exposición", se establecen para cada agente químico identificado y constituyen criterios del riesgo, en el ámbito de la evaluación del riesgo de la exposición a los agentes químicos. Estos valores límite descritos en la normativa portuguesa, NP 1796:2014, se basan en las cifras propuestas por la American Conference of Governmental Industrial Hygienists (ACGIH) (Instituto Portugués de la Calidad (IPQ), 2014).

Los valores límite de exposición (VLE) corresponden a las concentraciones en el aire de las varias sustancias y representan condiciones para las cuales se admite que casi todos los operadores pueden estar expuestos, día tras día, sin efectos adversos para la salud. 
Sin embargo, a consecuencia de la amplia gama de susceptibilidad individual, es posible que un pequeño porcentaje de los operadores experimenten molestias para ciertas sustancias en concentraciones iguales o por debajo del valor permisible. Un porcentaje más pequeño puede ser afectado más seriamente por el agravamiento de una condición preexistente o por el desarrollo de una enfermedad profesional (Miguel, AS., 2006). Los empleadores deben tomar medidas para garantizar que la exposición de sus colaboradores no excede los VLE.

Se denominan hidrocarburos aromáticos, BTEX, a un conjunto de moléculas derivados básicos del benceno, formado por benceno, tolueno, etilbenceno e ortoxileno, metaxileno y paraxileno. A finales de los años 40 , se obtuvieron por primera vez hidrocarburos aromáticos procedentes del petróleo al inventarse el proceso catalítico de naftas. En la actualidad, la industria petroquímica basada en naftas de petróleo es la principal responsable por la producción mundial de BTEX (Lauwerys, R., 1994).

\section{Metabolismo de los disolventes orgánicos}

La inhalación y la absorción percutánea son las principales vías de absorción de los disolventes en la sangre periférica, que empieza unos pocos minutos después del inicio de la exposición (OMS, 1985; Engstrom, et al., 1978). La absorción por inhalación es la vía principal de entrada en el organismo y depende de la concentración de disolvente en el aire inhalado, el coeficiente de sangre/aire del disolvente (que se determina por la variabilidad individual en la permeabilidad de la membrana alvéolo-capilar y la solubilidad en la sangre), la tasa de ventilación alveolar, la perfusión pulmonar y la duración de la exposición (OMS, 1985; Astrand, 1975). Un incremento del ritmo de trabajo aumenta la ventilación pulmonar y la frecuencia cardíaca, lo que lleva al aumento de la 
absorción pulmonar del disolvente. Con el aumento del volumen por minuto del aire inhalado aumentan las concentraciones de contaminantes en las vías respiratorias. Otra forma importante de exposición ocupacional es el contacto dérmico, ya que los disolventes son fácilmente solubles en agua y en lípidos. La retención entre las ropas de trabajo y la a piel son también un factor que hace variar el grado de absorción del disolvente.

Se observó, por ejemplo, que la absorción percutánea después de la inmersión de ambas manos durante 15 minutos en xileno produjo concentraciones de xileno aproximadamente iguales a las obtenidas después de la inhalación de 100 ppm para igual período de tiempo (Engstrom et al., 1977). Esta absorción a través de la piel depende de:

a) duración del contacto;

b) grosor, perfusión y el grado de hidratación de la piel;

C) presencia de cortes, rozaduras y enfermedades de la piel (OIT, 2001; Xiao J.Q., 2000; Hartman DE., 2000; Millar JD., et al, 1987).

\section{Distribución y transformación}

Después de la absorción, los disolventes orgánicos pasan para la biotransformación (producida principalmente en el hígado), o se acumulan en los tejidos ricos en lípidos, tales como el sistema nervioso. El metabolismo hepático consiste, por lo general, en reacciones mistas oxidativas catalizadas por el sistema citocromo P-450, seguido por la conjugación con ácido glucurónico, ácido sulfúrico, glutatión, o glicina. El metabolismo generalmente resulta en la desintoxicación de disolventes orgánicos a través de la formación de los compuestos solubles en el agua que se excretan por la orina o la bilis. Sin embargo, el metabolismo también puede producir metabolitos intermediarios reactivos que son más tóxicos que el compuesto original. Estos metabolitos son capaces de unirse a través de enlaces covalentes a macromoléculas esenciales 
(por ejemplo, proteínas, DNA y RNA) y producir efectos tóxicos. La ingestión aguda de etanol en la sangre aumenta las concentraciones de tolueno y xileno, a través de la competición para el metabolismo, mientras que la ingestión crónica del etanol induce enzimas de disolventes y, por lo tanto, disminuye las concentraciones sanguíneas de disolvente. El lugar de trabajo, dónde hay exposición simultánea a varios disolventes o a su mezcla, puede conllevar a interacciones metabólicas similares (OIT, 2001; Xiao J.Q., 2000; Hartman DE., 2000; Millar JD., et al, 1987).

\section{Eliminación}

La eliminación de los disolventes ocurre por medio de la exhalación del compuesto en el aire expirado o por la excreción urinaria o biliar de los metabolitos solubles en agua (OIT, 2001; Xiao J.Q., 2000; Hartman DE., 2000; Millar JD., et al, 1987). 


\section{Neurotoxicidad, carcinogenicidad y las manifestaciones en la salud}

Se puede definir como neurotoxicidad a la capacidad de inducir efectos adversos en el sistema nervioso central (SNC), en el sistema nervioso periférico (SNP) y en los órganos de los sentidos y a los productos químicos neurotóxicos como aquellos que son capaces de inducir un modelo definido constante de disfunción nerviosa a través de su nocividad en la estructura química del SNC.

- pérdida de la visión;

- pérdida de la audición;

- pérdida del olfato;

- disminución de la capacidad para controlar los movimientos;

- disminución de la capacidad de almacenar e interpretar información;

- disturbios comportamentales o psicológicos.

Los cambios en el humor o personalidad son una ocurrencia común después de lesiones cerebrales (OIT, 2001; Xiao JQ., 2000).

Las lesiones del SNC causadas por sustancias neurotóxicas no se reconocen con facilidad por métodos convencionales de diagnóstico clínico, y sus manifestaciones son expresas de varias formas de trastornos de la función neuropsicológica (OIT, 2001).

Los métodos de estudio de los efectos neurotóxicos sobre el sistema nervioso central y periférico buscan superar las dificultades planteadas por manifestaciones leves y subclínicas, la falta de selectividad de afecciones de las substancias por un sistema o nivel neurológico y la correlación con un nivel de exposición específico, ante la utilización de mediciones sensibles de los efectos producidos (OIT, 2001). 
Los pintores están expuestos a una amplia gama de mezclas complejas que incluyen un número de productos químicos carcinógenos y mutagénicos incluyendo disolventes orgánicos y de colorantes. Los resultados de un estudio realizado en Nueva Zelanda son consistentes con estudios previos que muestran un aumento del riesgo de cánceres urológicos y hemáticos entre los pintores. EI estudio encontró un exceso de casos de múltiples mielomas entre los artistas (Bethwaite, P., 1990).

\section{Características toxicocinéticas y dinámicas del tolueno}

El tolueno es un líquido límpido, incoloro con un olor característico. Es un buen disolvente (una sustancia que puede disolver otras sustancias). El tolueno se usa en la fabricación de tintas, disolventes de tinta, esmalte de uñas, barnices, adhesivos y goma, limpieza solvente y, en algunos procesos de impresión y curtido del cuero. El olor puede notarse en el aire a partir de una concentración de 8 partes de tolueno por millón de partes de aire (ppm), y el sabor en el agua con una concentración de entre 0,04 y $1 \mathrm{ppm}$. Cuando se trabaja con materiales que lo contengan, éste se evapora y se mezcla en el aire que respiramos (Agency for Toxic Sustances and Disease Registry (ATSDR), 2007).

La exposición al tolueno puede ocurrir de varias maneras, incluyendo agua, alimentos, aire y productos de consumo. El lugar de trabajo puede ser la principal fuente de contaminación con tolueno cuando los trabajadores están expuestos a materiales que lo contienen en su composición, en particular si las medidas preventivas adoptadas no son las más adecuadas. El tolueno puede entrar en el organismo a través de la respiración de sus vapores, de los alimentos o del agua contaminada. Cuando hay exposición a productos que contienen tolueno en diversas formas de aplicación, éste también puede penetrar 
a través de la piel y entrar en el corriente sanguíneo. Después de la entrada en el cuerpo, más del $75 \%$ se retira en 72 horas. La mayoría del tolueno inhalado o ingerido se elimina en la orina dentro de las 12 horas después de la exposición. Una pequeña cantidad (hasta el 20\%) se excreta en el aire espirado como una solución libre de tolueno y menos del $2 \%$ de los metabolitos se excretan en la bilis (Tolueno ATSDR, 2000).

Después de una exposición única, la eliminación de tolueno y sus metabolitos es casi completa en 24 h (Stellman et al, 2001; Horowitz, 2001).

Por lo general, el organismo transforma el tolueno en productos químicos menos perjudiciales, tales como ácido hipúrico (Agency for Toxic Substances and Disease Registry (ATSDR), Toluene, 2000). Además del ácido hipúrico, otro metabolito resultante de la transformación del tolueno en el cuerpo son los isómeros de o-Cresol en la orina.

De acuerdo con las recomendaciones de la ACGIH - American Conference of Governmental Industrial Hygienists - y adaptadas a la normativa NP 1796 en 2014, los metabolitos del tolueno se convirtieron en: tolueno en la sangre con un valor límite biológico (VLB) de $0,02 \mathrm{mg} / \mathrm{L}$, tolueno en la orina con VLB $0,03 \mathrm{mg} / \mathrm{L}$ y o-Cresol en la orina VLB $0,3 \mathrm{mg} / \mathrm{g}$ de creatinina.

El tolueno puede causar dolores de cabeza y somnolencia y puede afectar la capacidad de razonamiento. Los efectos están dependientes de la cantidad que entra en el cuerpo, tiempo de exposición, la susceptibilidad genética y la edad. Una exposición baja o moderada en el trabajo, día tras día, puede causar cansancio, confusión, debilidad, efecto de embriaguez, pérdida de memoria, náuseas y pérdida de apetito. Estos síntomas generalmente desaparecen después del cese de la exposición. Después de la exposición crónica al tolueno, los efectos neurológicos más comunes se manifiestan en: 
- a) trastornos cognitivos tales como confusión, demencia y deterioro mental;

- b) trastornos neuropsiquiátricos, como labilidad emocional, psicosis, encefalopatías, insomnio y trastornos de la personalidad;

c) alteraciones en los nervios craneales, como anosmia, trastornos oculomotores, neurosensorial de la audición, alteraciones del nervio óptico y de la función vestibular;

- d) a nivel cerebeloso, ataxia, disartria, nistagmo y piramidales;

- e) disfunción del sistema nervioso periférico y autonómico: debilidad persistente (laxitud), alteración de la función neuromuscular, y la neurastenia (OMS, 1985; Horowitz, 2001; ATSDR Toluene, 2000).

Las alteraciones hepáticas pueden causar desde la disfunción hepática de subclínico hasta la necrosis hepática masiva. En los trabajadores con exposición prolongada pueden ser observadas alteraciones como:

- hepatomegalia;

- aumento del tiempo de protrombina;

- esteatosis hepática no alcohólica;

- insuficiencia hepática aguda;

- aumento del riesgo de tumores hepáticos primarios (Bosia, 2005).

El grado de daño hepático depende de la dosis, de la duración de la exposición, de la actividad y del metabolismo de las enzimas hepáticas y de la susceptibilidad individual (Farrell, 2002). 
Se han reportado efectos cardiovasculares como las arritmias cardíacas, incluyendo contracciones prematuras taquicardias supraventriculares y multifocales. Estos efectos pueden deberse a trastornos electrolíticos, hipoxia y acidosis causadas por la hipoventilación mediada por el sistema nervioso central o la toxicidad directa de las células cardíacas (Horowitz, 2001; ATSDR tolueno, 2000).

En cuanto al sistema músculo-esquelético, el tolueno puede causar efectos tóxicos directos sobre la membrana muscular. La hipocalemia y hipofosfatemia pueden causar debilidad muscular. Casos de rabdomiólisis también pueden ocurrir (Horowitz, 2001).

La naturaleza lipofílica del tolueno permite que pase fácilmente a través de la placenta. El retraso en el desarrollo y en el crecimiento intrauterino, parto prematuro, (Donald, 1991) anomalías congénitas, muerte perinatal y acidosis neonatal se han asociado con el abuso de tolueno durante el embarazo. Las embriopatologías como microcefalia, rasgos dismórficos craneofaciales y retraso en el desarrollo se han descrito por inhalación de tolueno durante el embarazo (Horowitz, 2001).

Se han encontrado datos compatibles con un ligero aumento en el riesgo de cáncer rectal asociado a la exposición tolueno, aunque se sugiera el ajuste a otros factores de riesgo en el trabajo que pueden interferir con los resultados (S. Dumas et al., 2000).

Una inhalación de una gran cantidad de tolueno en un corto período de tiempo puede causar mareos, somnolencia, y causar desmayos. Si continúa esta exposición puede causar la muerte. Si la exposición se interrumpe los mareos y la somnolencia desaparecen, sin embargo, si persiste, puede causar daños cerebrales permanentes. Además, problemas con el habla, la visión, la audición, la pérdida del control muscular, la pérdida de memoria, la falta de equilibrio, y la 
disminución de la capacidad mental pueden ser permanentes (ATSDR Tolueno, 2000; International Agency for Research on Cancer, IARC (1999a). El tolueno (en niveles altos) podrá dañar los riñones. La combinación de la exposición al tolueno conjugada con el consumo de bebidas alcohólicas puede afectar el hígado de una manera sinérgica, es decir, el deterioro es mayor que la suma de sus efectos separados (ATSDR, 2000).

La naturaleza lipofílica del tolueno puede resultar en lesiones con preferencia en el sistema de fibra mielinizadas, tejido rico en lípidos en el sistema nervioso central que son por sus características relativamente estables. Eso puede resultar en secuelas neurológicas prolongadas o permanentes (Horowitz, 2001).

La combinación de tolueno y algunos medicamentos comunes como la aspirina y el acetoaminofeno puede aumentar el efecto tolueno sobre la audición (ATSDR, 2000).

Los efectos del tolueno se adiestran más bien en el sistema nervioso central, el hígado, los riñones y los pulmones (ATSDR, 2000). 


\section{Características toxicocinéticas y dinámicas del xileno}

El xileno se puede presentar en tres formas, donde los grupos metilo varían en el anillo bencénico: metaxileno, ortoxileno, paraxileno ( $\mathrm{m}-$, o- y $\mathrm{p}$ xileno). Estas diferentes formas se denominan de isómeros.

Cuando la literatura indica xilenos totales se refiere a todos los isómeros (m-, o- y p-xileno). La mezcla de xilenos se compone de tres isómeros y por lo general también contiene $15,6 \%$ de etilbenceno (Agency for Toxic Substances and Disease Registry (ATSDR Xileno, 2007). El xileno también se conoce como xilol o dimetilbenceno.

El xileno es un líquido incoloro con un olor dulce que es fácilmente inflamable. Se puede encontrar de forma natural en el petróleo y el alquitrán. A un nivel industrial es producido a partir del petróleo.

Se utiliza principalmente como disolvente en las industrias de impresión, goma y cuero. Junto con otros disolventes, el xileno también se usa ampliamente como un agente de limpieza, disolvente de tinta y en barnices. El xileno se utiliza en menor medida, en la industria química, plásticos y fibras sintéticas. Isómeros de xileno se utilizan en la fabricación de ciertos polímeros para la fabricación de plásticos. El xileno se encuentra en pequeñas cantidades en el combustible de avión y en la gasolina (ATSDR Xileno, 2007). En algunos estudios se ha señalado la importancia de la exposición de estos compuestos orgánicos volátiles en los consumibles, sobre todo en un entorno doméstico (pegamento, tintas, esmaltes, barnices) que puede producir una concentración superior a $1.000 \mathrm{mg} / \mathrm{m} 3$ (Croute, et al. 2,002). Después de ser procesados, los productos químicos y petroquímicos resultan en envases, perfumes, muebles, materiales de construcción (cemento), prendas de vestir, calzado, componentes industriales (industria de la computación electrónica, automotora y aeronáutica), tintas, productos de limpieza, colorantes, medicinas, productos químicos y fertilizantes 
agrícolas, aceite de inmersión para microscopía, barnices, agentes clarificantes para los cortes histológicos, la materia prima para la producción del ácido benzoico, anhídrido ftálico, ácido isoftálico y éster de dimetilo (Beasley, 1992;. Riihimaki et al, 1982b). El xileno es un producto esencial para la realización de pruebas de anatomía patológica y citología (Dias-Teixeira, M., 2009). Su función es hacer los tejidos translúcidos, participando en la etapa de blanqueo o diafanización de éstos (Junqueira y Carneiro, 2004).

El vapor de xileno es absorbido rápidamente en los pulmones y en forma líquida es absorbido lentamente a través de la piel (Riihimaki y Pfäffli, 1978). La absorción pulmonar de vapores es similar para todos los isómeros de xileno. Aproximadamente el $60-65 \%$ de xileno inhalado es absorbido (Šedivec, 1976). La capacidad de retención no varía con la intensidad y la duración de la exposición sino con la capacidad de ventilación (Lauwerys, 1994; Šedivec, 1976). Las propiedades lipofílicas permiten el paso a través de la membrana celular y su acumulación en el sistema nervioso central (Horowitz, 2001). El xileno absorbido, 95\% se metaboliza en el hígado en ácidos metilbenzoicos (Langman, 1994). Estos ácidos se combinan con glicina para formar el ácido orto, meta o para-hipúrico metilo, que se excretan en la orina (Lauwerys, 1994; Ogata, 1970). Alrededor del $70-80 \%$ de los metabolitos se excretan en la orina dentro de las 24 horas (Langman, 1994). Sólo el 3 a 6\% se excreta sin cambios en el aire exhalado. El tiempo medio de eliminación es más de 20 a 30 horas (Lauwerys, 1994). 
La exposición aguda al xileno causa irritación en los ojos, las mucosas de las vías respiratorias y síntomas de depresión del sistema nervioso central incluyendo narcosis, anestesia, euforia, mareos, ataxia y cefalea. Otros efectos incluyen trastornos de la articulación de la palabra, confusión, pérdida de memoria temporal, desorientación, temblores e irritabilidad. Las depresiones del sistema nervioso central pueden resultar en letargo, insuficiencia respiratoria y muerte en muchos casos (Stellman et al., 2001; Horowitz, 2001).

Efectos gastrointestinales como náuseas, vómitos, moretones y dolor abdominal son las quejas más comunes en los pacientes sometidos a la exposición aguda por inhalación al xileno. También se han reportado valores altos transitorios de las pruebas de función hepática (Horowitz, 2001; Stellman et al., 2001).

Una exposición ocupacional crónica al xileno se ha asociado con la disfunción neuropsicológica, anemia, trombocitopenia, leucopenia, disnea y cianosis (Langman, 1994). En el sistema nervioso se manifiesta por debilidad general, mareos, dolor de cabeza, irritabilidad, insomnio, fatiga extrema, temblores, falta de concentración, pérdida de memoria a corto plazo y zumbido en los oídos. El contacto directo en los ojos causa irritación, conjuntivitis y daño de la córnea y en la piel puede causar alteraciones, en particular eczema (Stellman, et al., 2001), irritación y dermatitis (Beasley, 1992; Merck \& CO 1995; Trujillo et al., 2003).

Las mujeres pueden experimentar cambios en los ciclos menstruales que se manifiestan en menorragia o metrorragia. Durante el embarazo puede causar toxicosis, el riesgo de aborto involuntario y el sangrado durante el parto, además de poder causar esterilidad (Horowitz, 2001; Stellman et al., 2001).

La inhalación de tolueno o xileno puede inducir trastornos fonológicos, visuales, auditivos, motores y puede estar relacionado con la aparición de los 
tumores cerebrales y leucemias linfocíticas cuando se combina con benceno (Irwin et al 1997; Tiburtius et al., 2004).

Sigue habiendo una pequeña evidencia de que xileno en altas dosis se es carditóxico en los seres humanos. Un estudio realizado mostró que en cada 5 de 25 hombres hospitalizados, tras contacto con la tinta, se detectaron arritmias ventriculares prematuras y contracciones multifocales (Streicher et al., 1981).

En un estudio realizado en los Estados Unidos de América fue descubierto el aumento de la mortalidad debido a linfomas entre los trabajadores de los muebles de madera cuando expuestos al xileno y otros disolventes orgánicos (Miller, B.A. 1989). Un pequeño exceso de linfosarcoma fue relatado entre los trabajadores de goma expuestos a xileno (Wilkosky, TC et al., 1984) y la aparición de linfomas fue alta entre los trabajadores expuestos a disolventes orgánicos y clorofenoles (Harrell, L. et al. 1,981; Viana, N.J .et al, 1979).

El xileno no está clasificado como un agente carcinógeno en los humanos y pocos estudios epidemiológicos se han hecho con respecto a esta sustancia por sí sola. Según Rego (1999), los trabajadores que manipulan productos químicos están por lo general más expuestos a sustancias cancerígenas y esto ha sido considerado uno de los mayores riesgos para los seres humanos. La exposición ocupacional a disolventes orgánicos puede contribuir a la aparición de los Linfomas no-Hodgkin y el sinergismo con otros factores puede ser un aspecto importante del proceso de la linfomagénesis (Rego, 1999). 
El xileno en concentraciones de 200 ppm o superiores causa irritación de las membranas y mucosas, náuseas, vómitos, mareos y falta de coordinación. Las concentraciones de xileno en la sangre por encima de $3 \mathrm{mg} / \mathrm{L}$ son producidas por la exposición sedentaria de los individuos a los 300-400 ppm de xileno (Savolainen et al., 1979).

Las concentraciones en el aire superior a 10.000 ppm de xileno han causado inconsciencia en los trabajadores debido a la depresión del sistema nervioso central, hasta la muerte (Morley et al., 1970).

El xileno en estudios comparativos, afectó a los umbrales auditivos en frecuencias más bajas que el tolueno y se detectó una pérdida de la sensibilidad auditiva en las frecuencias medias en todos los estudios (Gagnaire F., Brigitte M, Langlais C., Pierre P., 2000). En Australia y Nueva Zelanda, el xileno es considerado por la ley como un agente ototóxico industrial (AS/NZS1269.0: 2005). En 2004, el gobierno australiano recomendó que la exposición diaria al ruido de los trabajadores expuestos a los disolventes fuese reducida a menos de $80 \mathrm{dBA}$, y que se realicen regularmente pruebas audiométricas.

\section{Características toxicocinéticas y dinámicas del etilbenceno}

El etilbenceno es un líquido incoloro inflamable y olor similar a la gasolina. Está presente en los productos naturales, tales como el carbón y el petróleo, así como en la fabricación de productos tales como tintas, barnices e insecticidas (ATSDR, Etilbenceno, 1999).

Su perfil toxicocinético es muy similar a los xilenos, es absorbido preferentemente por inhalación, sin embargo, por ingestión también causa una absorción rápida y eficiente. La absorción por la piel es más lenta. El etilbenceno tiene una baja toxicidad en los animales y en el hombre, sea en las exposiciones 
agudas sea en las crónicas. Los principales efectos tóxicos se producen en el sistema nervioso central que actúa como un depresor. También es un irritante para las mucosas, los ojos y las vías respiratorias (Moreno Gray, 2003)

La exposición al etilbenceno a una concentración de 1.000 ppm en el aire causa la irritación de los ojos y la nariz. A concentraciones de 2.000 ppm o más puede causar el lagrimeo, mareos y la depresión del sistema nervioso central (Lewis, R., 1998; Randall, C. y Creavey, R., 2002).

El etilbenceno se metaboliza en el cuerpo humano, por oxidación de la cadena alifática en el metilfenilcarbinol. La oxidación de este primer metabolito produce los ácidos mandélico y fenilglioxilico, que representan el 64 y el 25\%, respectivamente de una dosis inhalada de etilbenceno y posteriormente excretados en la orina. Sólo una pequeña parte de la dosis se excreta sin metabolizarse a través del aire espirado y la orina (Randall, C. y Creavey, R., 2002).

La excreción urinaria de ácido mandélico alcanza un máximo durante las últimas 2 horas de exposición de 8 horas, y luego decae con el tiempo de vida medio de 4-7 horas después del final de la exposición. La concentración de ácido mandélico determinado en la orina de los trabajadores expuestos a el etilbenceno, a una concentración de 92 ppm en la atmósfera durante ocho horas, fue de 900 ppm (Randall, C. \& Creavey, R., 2002). 
Se llevó a cabo un estudio en el que se detectó que el etilbenceno líquido, ya sea puro o disuelto se absorbe a través de la piel intacta de los voluntarios (Dutkiewicz, et al., 1967). La tasa media de absorción de etilbenceno líquido aplicado a una superficie de $17,3 \mathrm{~cm}^{2}$ del antebrazo de siete voluntarios durante 10-15 minutos fue de $38 \mathrm{mg} / \mathrm{cm}^{2} / \mathrm{h}$. Los investigadores concluyeron que el índice de absorción a través de la piel es superior a otras sustancias tales como anilina, benceno, nitrobenceno, sulfuro de carbono y estireno.

En un estudio sobre la exposición cutánea de los vapores de etilbenceno (1300 mg/m³ o 300 ppm), durante dos horas entre el $90 \%$ y el 95\% de su piel a vapor etilbenceno, no reveló un aumento del ácido mandélico, que es el principal metabolito de etilbenceno en la orina (Gromiec et al., 1984).

La absorción de etilbenceno a través de los pulmones de individuos expuestos a concentraciones de aproximadamente 100 a 200 ppm durante 8 horas fue investigada por Bardodej y Bardodejova (1970). Estos autores encontraron que para un estado de retención (equilibrio) entre el $45 \%$ y el 50\% del etilbenceno inhalado es retenido. Un segundo estudio fue un valor sencillamente más alto, el 65\% (Gromiec et al., 1984).

El etilbenceno tiene propiedades anestésicas en altos niveles de exposición, lo que sugiere que los efectos sobre el sistema nervioso central también serán importantes para los niveles inferiores (Yant et al., 1930). Se detectaron cambios en los niveles de norepinefrina y dopamina en el hipotálamo de ratones expuestos a $2.000 \mathrm{ppm}\left(8.840 \mathrm{mg} / \mathrm{m}^{3}\right)$ de etilbenceno durante 6 horas/día durante tres días (Anderson et al., 1981), aunque no se hayan observado cambios de comportamiento. 
Casi no hay información sobre los efectos tóxicos de etilbenceno puro en los seres humanos ya que la exposición se produce normalmente en combinación con otros disolventes. En cuanto a la composición de tintas, barnices y tapaporos para el sector del mueble los porcentajes normales son alrededor del 2 al $5 \%$.

Se relató que el nivel de exposición de 200 ppm es irritante (Ruth, 1986). Se estima que la concentración de etilbenceno inhalado requerida para deprimir la frecuencia respiratoria en el $50 \%$ es de aproximadamente 1.430 ppm durante un período de unos cinco minutos (Ceaurriz et al., 1981).

Ivanov (1964) presentó los resultados de un estudio de los trabajadores industriales expuestos solamente a etilbenceno en un nivel máximo de 14 ppm. La mayoría de los trabajadores se han quejado de dolores de cabeza, de irritabilidad y de cansancio rápido. Se detectaron alteraciones en el sistema nervioso funcional de los trabajadores que trabajaban hace más de siete años. Además, algunos trabajadores mostraron un aumento de tamaño del hígado.

Hay evidencia de daño coclear en modelos animales expuestos a diferentes concentraciones de etilbenceno (Vyskocil et al., 2008b). Se destacan los cambios en la respuesta a las frecuencias medias y bajas, con la pérdida de las células ciliadas externas en ratones, un efecto relacionado con la especie (Cappaert, Klis, Baretta, Muijser y Smoorenburg, 2000; Cappaert et al., 2002). 


\section{Objetivos}

\section{Objetivo General:}

Evaluar la percepción y los riesgos de los trabajadores de las fábricas de muebles de la exposición ocupacional al tolueno y xileno.

\section{Objetivos específicos}

- Determinar la percepción de los trabajadores de las fábricas de muebles el riesgo para la salud de la exposición al tolueno y xileno.

- Cuantificar los niveles ambientales de tolueno y xileno (isómeros y etilbenceno) en las fábricas de muebles.

- Medir los índices biológicos de exposición profesional de los trabajadores de las fábricas de muebles al tolueno y xileno. 


\section{Metodología}

Para el desarrollo de este trabajo, hemos aplicado dos enfoques metodológicos diferentes. Primero, la aplicación de un cuestionario (Anexo 7.1) después las evaluaciones de la calidad del aire y biomonitorizaciones. Las tareas se desarrollaran en el siguiente orden:

$1^{\circ}$ - Recopilación de datos para caracterizar la muestra y el consecuente estudio exploratorio;

$2^{\circ}$ - Aplicación de un cuestionario de la prueba y la aplicación del cuestionario final;

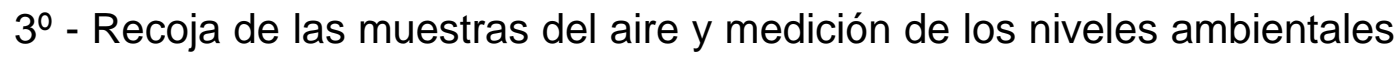
de tolueno, xileno y etilbenceno;

4ํ- - Cuantificación de los índices biológicos de exposición al tolueno, xileno (isómeros) y etilbenceno.

\section{Aplicación de los cuestionarios}

Los cuestionarios son un instrumento de investigación, compuesto por un número más o menos elevado de preguntas presentadas por escrito, teniendo como objetivo el conocimiento de las opiniones, creencias, sentimientos, intereses, expectativas y situaciones vividas. Es una herramienta de recopilación y validación de datos, de suma importancia, sobre todo cuando nos enfrentamos a variables de naturaleza subjetiva, es decir, la percepción de riesgo, la opinión sobre los aspectos de seguridad y equipos de protección personal. La 
construcción del cuestionario se llevó a cabo de una manera estructurada, teniendo en cuenta los elementos a estudiar, las escalas a adoptar y su facilidad de interpretación.

Inicialmente, se aplicó el cuestionario prueba, seguido de una nueva prueba, cuyo objetivo era mejorar la adaptación de las mismas. Tanto la prueba y la nueva prueba se llevaron a cabo en febrero y marzo de 2014, respectivamente. Para este propósito, se seleccionó una muestra sistemática del $40 \%$ del universo de 142 trabajadores.

El cuestionario final se distribuyó personalmente a la población objeto de estudio, en abril y mayo de 2014. Este procedimiento permitió transmitir a los trabajadores una garantía de confidencialidad de las respuestas, a través de la cual se tenía la intención de minimizar cualquier distorsión de los resultados. Éste tuvo una duración aproximada de 10 minutos y fue devuelto de inmediato.

La información recogida se refiere a:

- conocimiento de riesgos de los productos químicos;

- conocimiento de los productos químicos utilizados;

- comportamientos en el manejo de productos químicos;

- percepción de la exposición a tintas, barnices y tapaporos;

- uso de equipos de protección personal;

- uso de equipos de protección colectiva;

- efectos fisiológicos posteriores de la exposición a la tinta, barnices y tapaporos;

- interferencia del puesto de trabajo en la exposición;

- frecuencia de las medidas preventivas;

- formación en materia de seguridad y salud laboral. 
La escala opcional utilizada se basa en la metodología del tipo Likert (7 opciones), adaptada de acuerdo con la dimensión a evaluar, como se describe a continuación. Con relación a la codificación de las respuestas, se eligió un valor numérico, denominado de puntuación, utilizando una escala unipolar de 0 a 6.

\section{Monitoreo Ambiental y Biológico}

La determinación analítica de tolueno, xileno y etilbenceno, y los respectivos metabolitos urinarios, se hizo en el laboratorio del Grupo de Reacción y Análisis Químico (GRAQ) - Instituto Superior de Ingeniería de Oporto.

\section{Muestreo y determinación analítica}

Los muestreos se realizaron en puestos de trabajo existentes en las áreas de aplicación de tintas, barnices y tapaporos. Esta operación consiste en colocar una mezcla de aditivos (disolventes, secado, catalizador, etc.) en las tintas, barnices o tapaporos en una pistola neumática para proyección de los aerosoles sobre las piezas de madera. El operador hace esta mezcla, la coloca en el depósito de la pistola o en el contenedor de apoyo y aplica en las piezas. Las aplicaciones pueden ser hechas en una cabina de pintura con filtro a seco, en una cabina con cortina de agua o sistemas de cabina automáticos 0 semiautomáticos. Estas aplicaciones son las necesarias para dar el acabado superficial de las piezas de madera, así se logran producir piezas con diferentes colores, brillo y textura. 


\section{Muestreo ambiental}

Las muestras de aire ambiente se recogieron entre julio y noviembre de 2014. El procedimiento fue el de recoger tres muestras usando tubos de carbón activado (SKC - Anasorb® CSC: coconut charcoal, 20/40 mesh, 50/100 mg) activado (Figura 11, Figura 12 y la Figura 13) y una bomba independiente de muestreo (modelo estándar SKC - 224-44EX) (Figura 14). Se cortaron los dos extremos de los cartuchos. La tasa de flujo aplicada varió entre 0,13 y $0,19 \mathrm{~L}$ min-1 durante 15 minutos. El muestreador personal se colocó en la solapa del trabajador en el que se realizó el muestreo del aire en la zona de respiración.

El tiempo de muestreo (15 minutos) se controló con la ayuda de un cronómetro (Oregon Scientific).

Se llevaron a cabo 108 muestras de aire para la determinación de tolueno, xileno y etilbenceno. Para la determinación analítica de sustancias en las muestras del aire interior en las zonas de aplicación de tintas, barnices y tapaporos se realizó por cromatografía de gases con detector de ionización de llama (GC-FID) de acuerdo con el método NIOSH 1501 (Pendergrass MS, 2003).

Por cada 10 muestras analizadas se introdujo un control de calidad (blanco). 


\section{Muestreo biológico}

El muestreo se realizó de manera a garantizar que la muestra fuera representativa. Se hicieron recogidas de orina para un bote de polipropileno esterilizado de $100 \mathrm{ml}$ antes y al final del turno de 8 horas de jornada. Las muestras de orina se almacenaron bajo refrigeración a $-4{ }^{\circ} \mathrm{C}$ hasta su análisis.

La determinación urinaria de creatinina y xileno metabolitos, tolueno y etilbenceno se realizó por cromatografía líquida de alta precisión con detector Diode Array (HPLC-DAD) (Dias-Teixeira et al., 2010; Motock GT Perkins JB, \& Reynolds JM, 2003).

La determinación del indicador biológico de la exposición del tolueno, Ocresol se realizó por GC-FID (LC Amorim \& Alvarez-Leite, 1997).

Por cada 10 muestras analizadas se introdujo un control de calidad.

\section{Análisis estadístico}

Se realizó el análisis de los datos usando el software estadístico SPSS para el Windows (SPSS Inc., 2012). Para describir los resultados se utilizaron las herramientas de estadística descriptiva (media y desviación estándar) e inferencial ante la aplicación de la prueba de Qui-cuadrado y Mann Whitney para el análisis de la asociación entre las categorías. El nivel de significancia adoptado para las pruebas estadísticas fue de $5 \%$, es decir, $p<0.05$. Se 
comprobó la consistencia interna del instrumento (prueba, prueba-nueva y cuestionario final), para eso se calculó el coeficiente de Cronbach. Se consideró que para que el instrumento sea adecuado, los valores deben ser iguales o superiores a 0,50, ya que este índice ha sido utilizado por los investigadores en los estudios de validación de escalas.

\section{Resultados}

\section{La caracterización de la muestra}

En este estudio participaron 142 empleados de todas las empresas de más de 15 funcionarios de los distritos (provincias) de Aveiro, Coimbra y Viseu en la industria del mueble dentro de los códigos de actividad económica 31010 fabricación de muebles para oficina y tienda; 31020 - fabricación de muebles de cocina y 31091 - fabricación de muebles de madera para otros fines.

\section{Análisis de la percepción y riesgo de exposición}

Las tintas, barnices y tapaporos se componen de xileno, tolueno y etilbenceno, entre otras sustancias químicas peligrosas, y es preocupante el hecho de que los trabajadores clasifiquen entre bajo y medio el riesgo de exposición a estos productos químicos, lo que revela la falta del conocimiento de los riesgos a ellos asociados. 
Esta falta de conocimiento acerca de los productos químicos utilizados también se revela cuando no se ponen de acuerdo en que tintas, barnices y tapaporos son de xileno y tolueno.

A nivel de la exposición, de la aplicación y de la manipulación en un promedio también responden tener poco o medio riesgo.

El uso de medios de protección colectiva es esencial en la prevención de la exposición a las sustancias químicas, incluso, desde un punto de vista normativo, la medida prioritaria [artículo 15 apartado j) de la Ley 102/2009 de 10 de septiembre, que aprueba el régimen jurídico de la promoción de la salud y seguridad en el trabajo, y la segunda modificación del Decreto-ley № 116/97 de 12 de mayo, que transpone al derecho interno la Directiva № 93/103/CE, del Consejo de 23 de noviembre, relativa a los requisitos de seguridad y salud mínimos para trabajar a bordo de barcos pesqueros, con la redacción de la Ley № 3/2014 de 28 de enero]. Los trabajadores usan las cabinas de aspiración, sin embargo, el 25,2\% refiere que tienen "siempre" el mantenimiento adecuado y el $20,1 \%$ "la mayoría de las veces", es decir, menos de la mitad de los trabajadores consideran el mantenimiento suficiente. Pero el mantenimiento y la limpieza de cabinas es esencial para su buen funcionamiento. Esto demuestra que es una situación alarmante, dado que el empresario ha invertido en estos equipos, pero que los trabajadores no están beneficiando de su eficiencia, desperdiciándose energía en su funcionamiento, es decir, sin rentabilizar sus reales capacidades.

De acuerdo con la normativa EN 14387:2004+A1:2008 los filtros adecuados son los filtros de gases y vapores orgánicos de punto de ebullición superior a los $65^{\circ} \mathrm{C}$. Durante el manejo de estos productos, y de acuerdo con las fichas de datos de seguridad de los productos utilizados, deben ser usados guantes de nitrilo, cumpliendo con las normativas EN 14387:2005 (Packham C., 2006; Department of Energy Office of Science, 2005). La normativa EN 
14605:2005+A1:2009 establece las especificaciones de los equipos de protección, así que para la protección contra los productos químicos pulverizados se recomienda utilizar equipos de protección de tipo 4 y desechables (NTP 929 - Ropa de protección contra productos químicos).

El 50,7\% de los trabajadores indican que siempre usan una máscara de protección en el manejo de las tintas, barnices y tapaporos, es decir que son la mitad de los trabajadores. Se añade el hecho de que, en promedio, no saben cuándo reemplazar los filtros de la máscara. También el 44,7\% de ellos indicó que la exposición a estos productos les provoca irritación en la nariz y garganta. Además el $65,5 \%$ de los empleados mencionó que había un fuerte olor a productos químicos en sus puestos de trabajo.

En cuanto al uso de guantes de protección durante las mediciones de los contaminantes en el aire interior, se registró el tipo de equipos de protección personal que los trabajadores estaban utilizando, y se verificó que la gran mayoría no estaba usando los guantes de protección adecuados. Utilizaron, entre otros, guantes de látex y guantes de goma recubiertos con tela en el dorso de la mano. Aproximadamente el $57,7 \%$ de los trabajadores está de acuerdo y el $16,2 \%$ totalmente de acuerdo que el empleador les proporcionó guantes de protección. También revelan que usan los guantes de protección y que el contacto de estos productos con la piel es peligroso.

Asimismo el $52,2 \%$ indica quedarse con la piel seca e irritada cuando no utiliza guantes. Sin embargo, el 57,1\% de los empleados están de acuerdo y el $10,7 \%$ totalmente de acuerdo que los guantes de protección que les dieron eran los más apropiados, demostrando que los trabajadores revelan una falta total de conocimiento sobre el tipo de guantes de protección más adecuado al manejar estas sustancias químicas. 
En lo que respecta a la sintomatología, es de verdad preocupante cuando el $45 \%$ de los trabajadores afirma que ya ha tenido irritación de la nariz y garganta, lo que demuestra que inhalaron estas sustancias químicas. Otra situación preocupante es que el $25,9 \%$ de los empleados mencionó que la exposición les causa dolores de cabeza. Los trabajadores indican (el 49,2\%) que existe fuerte ruido en el puesto de trabajo, lo que hace esta combinación peligrosa debido a los efectos ototóxicos de estas sustancias.

Cerca del $15,7 \%$ de los trabajadores reconoce que a veces ignoran algunas de las reglas de seguridad, el 10,8\% siempre y el 5,7\% la mayor parte del tiempo. Eso significa un total de 32,2\%, lo que nos lleva a la conclusión de que existe un problema de comportamiento de los trabajadores a pesar de que conozcan las reglas de seguridad.

\section{Análisis de los Monitoreos ambientales del aire en interiores}

Los resultados de las mediciones de las concentraciones de COVs en diferentes empresas mostraron que la media aritmética de ciertas concentraciones fue de $51 \mathrm{ppm}$ para el tolueno, $23 \mathrm{ppm}$ para el etilbenceno y 57 ppm para los isómeros de xileno.

Los valores encontrados son bastante superiores a los identificados en un estudio realizado en el Municipio de Paços de Ferreira, en 2007, por la Autoridad para las Condiciones de Trabajo en empresas del mismo ámbito, donde se detectó una concentración media del tolueno de 18,7 ppm, del etilbenceno de 5,2 ppm y del xileno de 19,7 ppm (ACT, 2007). 
La concentración máxima determinada en este estudio fue de 168 ppm para el tolueno, 56 ppm para el etilbenceno y 119 ppm para el xileno.

En las empresas estudiadas, el xileno fue la sustancia detectada en mayor abundancia en el aire de los trabajos analizados.

En las mediciones realizadas, el $56 \%$ de las muestras analizadas están por encima del Valor Límite Ambiental-Exposición Diaria (VLA-ED) para los isómeros de xileno establecidos en el Decreto Ley № 24/2012 el 06 de febrero (50 ppm) y el 8\% se encuentra por encima del VLA-ED de la NP 1796:2014 que es de 100 ppm. Si tenemos en cuenta los niveles de acción establecidos en la Normativa Reguladora 09 - Riesgos Ambientales, aprobado por el Decreto $\mathrm{N}^{\circ}$ 3214 de MTB, de 8 de junio de 1978 y el modificado por el Decreto № 25 SSST, de 29 de diciembre de 1994 (legislación brasileña) que determina como nivel de acción la mitad del valor límite de exposición. Sencillamente el $86 \%$ de las concentraciones de la media ponderada se encuentra por encima del nivel de acción. A nivel de las exposiciones de corto plazo (CP), el $16 \%$ de las mediciones son superiores a $100 \mathrm{ppm}$, valor establecido en el Decreto-Ley $n^{\circ}$ 24/2012, de 06 de febrero para el Valor Límite Ambiental-Exposición de Corta Duración (VLA-EC), y sólo el 2 \% de las evaluaciones se encuentran por encima de los valores límite, es decir, 150 ppm según la NP 1796:2014.

En relación con el tolueno, el 39\% de las mediciones muestran valores de las concentraciones por encima de la VLA-ED, es decir, $50 \mathrm{ppm}$, de acuerdo con el Decreto-Ley №. 24/2012, de 06 de febrero y hay incluso más del $44 \%$ de los lugares de trabajo que tienen concentraciones superiores a 20 ppm para el VLAED establecido en la Norma portuguesa 1796:2014 (NP 1796:2014). Por lo tanto, el $83 \%$ de los lugares de trabajo tienen valores de concentración de tolueno por encima de lo establecido en la NP 1796:2014. En comparación con el nivel de 
acción teniendo como referencia los 50 ppm (Decreto-Ley ํㅡㄴ 24/2012, de 06 de febrero), resulta que el $72 \%$ de los valores están por encima del nivel de acción. Contrastando con el valor de la NP 1796: 2.014 se ve que el $97 \%$ de las concentraciones son más altas que el nivel de acción. En cuanto a las exposiciones de corto plazo (CP) se observa que el $12 \%$ de las mediciones de 15 minutos son superiores al VLA-EC, es decir, 100 ppm establecido en el Decreto-Ley $n^{\circ}$ 24/2012, de 06 febrero.

Con relación al etilbenceno, las concentraciones no plantean ningún valor superior al VLA-ED, establecido por el Decreto-Ley $n^{\circ}$ 24/2012, de 06 de febrero, el cual es de $100 \mathrm{ppm}$. Sin embargo, resulta que el $56 \%$ de los valores están por encima de 20 ppm que se recomienda en la NP 1796:2014. Sencillamente el $92 \%$ de las concentraciones están por encima del nivel de acción. Con respecto a las concentraciones determinadas, no hay valores más altos que el VLA-EC, es decir, 200 ppm establecido en el Decreto-Ley nํ․ 24/2012, de 06 de febrero.

Sabiendo de los efectos de la exposición al xileno y tolueno y etilbenceno en los órganos / sistemas fisiológicos humanos, referenciados en la norma NP 1796:2014, verificamos que xileno provoca afecciones auditivas, daño renal e irritación del tracto respiratorio superior; el tolueno afecta a la vista (ojos), provoca lesiones en el tracto reproductivo femenino y el aborto, y el etilbenceno causa afecciones auditivas, daño renal e irritación del tracto respiratorio superior. La literatura, sobre todo en DLEP 39 - Documentación Toxicológica para el Estabelecimiento del Límite de la Exposición Profesional del Tolueno (INSHT, 2007) indica que el tolueno tiene efectos en el tracto respiratorio superior y afecta el sistema nervioso central, entre otros. Por lo tanto, teniendo en cuenta este efecto aditivo entre los isómeros de xileno, tolueno y etilbenceno, presentes en el aire de los puestos de trabajo analizados, se verifica que el $92 \%$ de las exposiciones a la mezcla supera los valores límite $(>1)$ y sólo el $8 \%$ está por debajo del valor límite de exposición $(<1)$. El promedio de estos valores es de 
2,6, se encontró incluso puestos de trabajo donde la concentración máxima de la mezcla fue de 5,5, estos datos muestran que, muy probablemente, los trabajadores pueden sufrir trastornos funcionales NP 1796: 2014.

\section{Análisis del Monitoreo de los Indicadores Biológicos de exposición en la orina}

Los valores obtenidos de los ácidos metilhipúrico desvelan que no son constituyentes normales de la orina, lo que muestra que no hay diferencias significativas antes y después de ocho horas diarias de exposición al xileno como se indica en estudios previos (Inoue et al., 1993).

En las muestras de orina recogidas antes de la exposición no se encuentran indicadores biológicos de la exposición. Después de una semana de trabajo y con 8 horas de exposición diarias, se detectaron en promedio 1,6 g/g creatinina de ácido metilhipúrico; $0,3 \mathrm{~g} / \mathrm{g}$ de creatinina de la suma de ácido fenilglioxilico con ácido mandélico; $1,9 \mathrm{~g} / \mathrm{g}$ de creatinina de ácido hipúrico y 0,3 $\mathrm{mg} / \mathrm{g}$ de creatinina o-Cresol. 


\section{Conclusión}

Los trabajadores de las empresas de fabricación de muebles estudiadas muestran una baja percepción del riesgo de exposición frente al tolueno, al etilbenceno y al xileno.

Teniendo en cuenta las concentraciones de Compuesto Orgánico Volátil detectadas podemos inferir que:

- el $56 \%$ de los lugares de trabajo estudiados tienen concentraciones de xileno por encima del VLA-ED establecido en el Decreto-Ley n‥ 24/2012, de 06 de febrero (50 ppm) y el 8\% están por encima del VLA-ED en la NP 1796:2014 (100 ppm).

- el 39\% de los lugares de trabajo que se han estudiado presentan concentraciones de tolueno superiores al VLA-ED establecido en el Decreto-Ley no. 24/2012, de 06 de febrero (50 ppm) y el 44\% están por encima del VLA-ED planteado en la NP 1796:2014 (20 ppm)

En ningún puesto de trabajo las concentraciones de etilbenceno detectadas sobrepasan el VLA-ED, establecido en el Decreto-Ley nㅜ. 24/2012, de 06 de febrero (100 ppm). Sin embargo, resulta que el 56\% de los empleados muestran concentraciones que exceden el VLA-ED recomendado en la NP 1796:2014 (20 ppm).

Las concentraciones urinarias de los indicadores biológicos de exposición a los contaminantes químicos estudiados mostraron que después de una semana de la jornada de trabajo y 8 horas diarias de exposición, los niveles 
medios de ácido metilhipúrico y ácido hipúrico sobrepasan los límites estipulados en la NP1796:2014 y ACGIH, 2015 para el xileno y tolueno, respectivamente. No obstante, para el actual indicador biológico de exposición al tolueno, O-cresol, los niveles medios detectados se encuentran dentro de los límites definidos por la NP1796:2014 (0,3 mg/g de creatinina).

Con este estudio, podemos concluir que la exposición a las tintas, barnices y tapaporos, hechas de entre varias sustancias por Compuestos Orgánicos Volátiles, con gran destaque para estas dos sustancias - el tolueno y el xileno - constituyen factores de riesgo para la salud de los trabajadores de fabricación de muebles. 
SIGLA SIGNIFICADO

ACGIH American Conference of Governmental Industrial Hygienists

ACT Autoridade para as Condições do Trabalho

ATSDR Agency for Toxic Substances and Disease Registry

CEE Comunidade Económica Europeia

COV Composto Orgânico Volátil

CG Cromatografia Gasosa

CL Cromatografia Líquida

DL Decreto-Lei

EN European Norm

EPI Equipamento de Proteção Individual

EPC Equipamento de Proteção Coletivo

FID Flame lonization Detector

IARC International Agency for Research on Cancer

IBE Índice Biológico de Exposição

IPQ Instituto Português da Qualidade

$\mathrm{kg} \quad$ Kilograma

L L Litro

LOD Limit of Detection

LOQ Limit of Quantification

m Metro

mg Miligrama

MHA Ácido metil-hipúrico

$\mathrm{mL} \quad$ Mililitro 
$\mathrm{NIOSH} \quad$ National Institute for Occupational Safety and Health

NP Norma Portuguesa

OIT Organização Internacional do Trabalho

OMS Organização Mundial de Saúde

OSHA Occupational Safety and Health Administration

IPCS International Programme on Chemical Safety

ppm Partes por milhão

SNC Sistema nervoso central

TLV Threshold limit values

TWA Time weighted average

UN United Nations

VLE-CD Valor limite de exposição - curta duração

VLE-CM Valor limite de exposição - concentração máxima

VLE-MP Valor limite de exposição - média ponderada

WHO World Health Organization 
INTRODUÇÃO 


\section{Introdução}

O Programa Internacional de Segurança Química composto pela Organização Mundial de Saúde (OMS), Organização das Nações Unidas (ONU) e Organização Internacional de Trabalho (OIT), estima em cerca de 100 mil o número de substâncias químicas puras existentes e em 4 milhões de compostos com utilização comercial (IPCS - International Programme on Chemical Safety, 1999).

As substâncias químicas existentes no ambiente de trabalho ocupam o mais extenso fator de risco profissional entre muitos condicionantes que afetam a saúde humana (Prista, J., Uva, A.S., 2002).

Nos últimos anos, com o avanço científico na área da genética abriram-se novos horizontes e possibilitou a utilização destes estudos para avaliar os danos e a suscetibilidade de trabalhadores aos agentes químicos.

A atenção aos efeitos dos agentes químicos alergénicos, interferentes endócrinos, carcinogénicos, mutagénicos e teratogénicos tem aumentado, cujas respostas seguem padrões diferentes da curva dose-resposta do tipo determinístico.

Em locais de trabalho de empresas tecnologicamente avançadas, normalmente os ambientes ocupacionais e as exposições a agentes químicos são controlados. Esta situação de modo geral foi consequência da democratização das informações sobre perigos químicos, da sensibilidade dos empregadores, da evolução tecnológica, da informação de trabalhadores, das ações dos órgãos de fiscalização, da evolução legislativa, da exigência comercial e concorrencial, da proteção ambiental, da atuação responsável de profissionais de segurança e de saúde e da própria mobilização da sociedade.

Por outro lado, com o aumento da complexidade dos produtos químicos, muito devido às exigências e preferências comerciais provocou um aumento do número de pessoas com exposições simultâneas a vários agentes químicos, 
provenientes de diversas fontes que, isoladas ou interagindo, criam novas e crescentes situações de risco. A estes fatores podemos acrescentar uma linha de desenvolvimento tecnológico que são a utilização de substâncias ao nível da nanotecnologia.

É, portanto, fundamental que se conheçam todos os fatores que de algum modo possam influenciar a proteção da saúde dos trabalhadores. Entre esses, se destacam, os efeitos adversos das substâncias utilizadas, o resultado da avaliação e das medidas de controlo adotadas, a monitorização biológica visando estimar o risco ocupacional e a adoção de medidas de proteção efetivas à saúde das pessoas expostas.

A maioria das pessoas passa cerca de $90 \%$ do seu tempo em espaços interiores, onde inúmeros perigos podem originar riscos para a saúde, reduzindo assim a sua qualidade de vida. A problemática da qualidade do ar tem vindo a ganhar expressão, já que muitas das queixas dos ocupantes são atribuídas a este fator. Uma boa qualidade do ar interior é tida como um dos parâmetros que mais contribui para a produtividade, conforto, saúde e bem-estar (Campos \& Santos, 2010).

A Higiene Industrial pode definir-se como uma técnica de atuação sobre os contaminantes (ou poluentes) do ambiente, derivados do trabalho, com o objetivo de prevenir as doenças profissionais dos indivíduos a eles expostos (Miguel, AS., 2006).

O ar puro é composto por 78,08\% de azoto, 20,94\% de oxigénio, 0,93\% de árgon, $0.03 \%$ de dióxido de carbono, 0.00005\% de hidrogénio e gases raros. O ar está poluído ou contaminado quando contém substâncias estranhas à sua composição normal, ou mesmo quando apresenta alterações quantitativas, pela presença de uma ou várias substâncias componentes superiores ou inferiores às normais (Miguel, AS, 2006). 
Segunda a ASHRAE (American Society of Heating, Refrigerating, and AirConditioning Engineers) a qualidade do ar pode ser aceitável se:

- No ar interior não se verificam concentrações nocivas de contaminantes;

- Mais de $80 \%$ das pessoas expostas não apresentam desagrado em relação às condições de qualidade do ar interior (Campos \& Santos, 2010).

Gioda e Aquino Neto (2003a) apontam para algumas fontes emissoras internas de contaminantes do ar: máquinas de escritório (fotocopiadoras), materiais de construção (tintas e vernizes) e decoração (carpetes e adesivos). Segundo Javier et al., (2003), essas fontes podem emitir até 900 compostos diferentes para $\mathrm{o}$ ar ambiente.

Dentre estes compostos estão os derivados de petróleo, chamados de hidrocarbonetos. Estes são moléculas orgânicas compostas de carbono e hidrogénio, que através de simples derivações de sua estrutura molecular, formam uma variedade de compostos (Baird, 1995). Os hidrocarbonetos fazem parte do principal grupo de compostos orgânicos voláteis na atmosfera (Kalabokas, et al., 2001), sendo suas concentrações em ambientes internos duas vezes maior do que em ambientes externos (Godish, 1991).

As principais fontes de hidrocarbonetos aromáticos são a destilação de hulha e uma série de processos petroquímicos, em particular a destilação catalítica, a destilação de petróleo cru e a alquilação de hidrocarbonetos aromáticos das séries mais baixas (Stellman, et al., 2001).

Em muitos países industrializados, a exposição a hidrocarbonetos aromáticos foi identificada como um problema de saúde pública por causa da grande utilização na indústria, formas inadequadas de manipulação e disposição desses produtos, que geram contaminação ambiental, laboral e efeitos sobre a saúde (Torres, et al., 2006). 
A exposição a hidrocarbonetos aromáticos utilizados em numerosos processos industriais considera-se um risco ocupacional para milhões de trabalhadores espalhados pelo mundo (Rodríguez, 2003).

O termo composto orgânico volátil (COV) é muito utilizado como sinónimo de solvente orgânico, sendo definido por diferentes metodologias de acordo com o país ou organização (Dewulf, et al., 2002).

Em muitos casos, as concentrações dos COV em ambientes internos são menores que os padrões permissíveis ocupacionais, de acordo com Godish (1991). Em níveis de cerca de $0,3 \mathrm{mg} / \mathrm{m}^{3}$, os COV combinados com condições inadequadas de conforto provocados por temperatura e humidade elevadas podem provocar irritação e desconforto, (Carmo e Prado, 1999). Estes sintomas são provocados pelo desenvolvimento de sensibilidade provocada pela contínua exposição aos COV (Becher, et al., 1996). Os COV têm sido associados também à presença de odores (Belli, Fo . e De Melo, 1998), onde os microrganismos são os principais responsáveis pela produção de substâncias aromáticas (Sunesson, et al., 1995). Além da hipersensibilidade, os hidrocarbonetos insaturados e/ou aromáticos possuem grande potencial mutagénico (Brickus e Aquino Neto, 1999).

A ação do tóxico sobre o organismo pode manifestar-se como uma doença clínica, transtornos funcionais ou modificações biológicas críticas, isto é, preditivas de uma alteração da saúde se persistem ou se repetem. 
A avaliação da eficácia das medidas de prevenção compreende três metodologias de vigilância:

- Determinar a concentração das substâncias químicas no ar dos postos de trabalho dos trabalhadores expostos (vigilância ou monitorização do ambiente);

- Avaliar mediante análises biológicas, (sangue, urina, ar espirado, etc.) efetuadas aos trabalhadores expostos, se a intensidade da exposição (dose interna) não é excessiva (vigilância ou monitorização biológica da exposição);

- Detetar lesões bioquímicas ou fisiológicas precoces, se possível num estado ainda reversível (vigilância do estado de saúde).

A análise do risco da exposição a agentes químicos associada ao desenvolvimento de atividades profissionais inclui a determinação da concentração daqueles agentes no ar dos locais de trabalho. Esta concentração, quando representativa da exposição profissional em estudo, é comparada com valores de referência que representam limiares de exposição correspondentes a níveis de risco aceitáveis.

Para melhor compreender os conceitos subjacentes às medições da qualidade do ar interior efetuadas, é importante ter em conta alguns conceitos, tais como: valores-limite de exposição e nível de ação.

Estes valores de referência, designados por "valores-limite de exposição", são estabelecidos para cada agente químico identificado e constituem critérios do risco, no âmbito da avaliação do risco da exposição a agentes químicos. Estes valores limite descritos na norma portuguesa, NP 1796:2014, têm por base os valores propostos pela American Conference of Governmental Industrial Hygienists (ACGIH) (Instituto Português da Qualidade (IPQ), 2014). 
Os valores limite de exposição (VLE) correspondem às concentrações no ar das várias substâncias e representam condições para as quais se admite quase todos os operadores poderem estar expostos, dia após dia, sem efeitos adversos para a saúde.

Porém, em virtude da grande amplitude de suscetibilidade individual, é possível que uma pequena percentagem de operadores experimentem desconforto para certas substâncias em concentrações iguais ou inferiores ao valor admissível. Uma percentagem mais pequena pode ser afetada mais seriamente pelo agravamento de uma condição preexistente ou pelo desenvolvimento de uma doença ocupacional (Miguel, AS., 2006). Os empregadores devem tomar medidas para garantir que a exposição dos seus colaboradores não excede os VLE.

Denomina-se hidrocarbonetos aromáticos, BTEX, a um conjunto de moléculas derivados básicos do benzeno, formado por benzeno, tolueno, etilbenzeno e orto-xileno, meta-xileno e para-xileno. Nos finais dos anos 40, obtiveram-se pela primeira vez hidrocarbonetos aromáticos procedentes do petróleo ao inventar-se o processo catalítico de naftas. Atualmente, a indústria petroquímica baseada em naftas de petróleo é a principal responsável pela produção mundial de BTEX (Lauwerys, R., 1994). 
Tabela 1 - Identificação química dos BTEX.

(Adaptado de OIT, 2001)

\begin{tabular}{|c|c|c|c|}
\hline Substância química & $\begin{array}{c}\text { Sinónimos/Código } \\
\text { UN }\end{array}$ & Número CAS & $\begin{array}{l}\text { Fórmula } \\
\text { estrutural }\end{array}$ \\
\hline Benzeno & $\begin{array}{l}\text { Ciclo-hexatrieno, } \\
\text { benzol, pirobenzol } \\
\text { UN1114 }\end{array}$ & $71-43-2$ & \\
\hline Etilbenzeno & $\begin{array}{l}\text { Feniletano, } \\
\text { etilbenzol } \\
\text { UN1175 }\end{array}$ & $100-41-4$ & \\
\hline Tolueno & $\begin{array}{l}\text { Metilbenzeno; } \\
\text { metilbenzol; } \\
\text { fenilmetano } \\
\text { UN1294 }\end{array}$ & $108-88-3$ & \\
\hline m-Xileno & $\begin{array}{c}\text { m-Dimetilbenzeno; } \\
\text { 1,3-dimetilbenzeno; } \\
\text { 1,3-xileno } \\
\text { UN1307 }\end{array}$ & $108-38-3$ & \\
\hline o-Xileno & $\begin{array}{c}\text { o-Dimetilbenzeno; } \\
\text { 1,2-dimetilbenzeno; } \\
\text { o-metiltolueno; } \\
\text { 1,2-xileno } \\
\text { UN1307 }\end{array}$ & $95-47-6$ & \\
\hline p-Xileno & $\begin{array}{c}\text { p-Dimetilbenzeno; } \\
\text { 1,4-dimetilbenzeno; } \\
\text { p-metiltolueno; } \\
\text { 1,4-xileno } \\
\text { UN1307 }\end{array}$ & $106-42-3$ & \\
\hline
\end{tabular}




\subsection{Metabolismo dos solventes orgânicos}

A inalação e absorção percutânea são as principais vias de absorção dos solventes no sangue periférico, que começa poucos minutos após o início da exposição (OMS, 1985; Engstrom, et al., 1978). A absorção por inalação é a via principal de entrada no organismo e depende da concentração de solvente no ar inalado, o coeficiente de sangue/ar do solvente (que é determinada pela variabilidade individual na permeabilidade da membrana alvéolo-capilar e solubilidade no sangue), a taxa de ventilação alveolar, perfusão pulmonar e a duração da exposição (OMS, 1985; Astrand 1975). Um aumento do ritmo de trabalho aumenta a ventilação pulmonar e frequência cardíaca, levando ao aumento da absorção pulmonar do solvente. Com o aumento do volume por minuto de ar inalado aumentam as concentrações de contaminantes nas vias respiratórias. Uma outra forma importante de exposição ocupacional é o contato dérmico, porque os solventes são facilmente solúveis em água e em lípidos, a retenção entre as roupas de trabalho e a pele são também um fator que faz variar o grau de absorção de solvente.

Observou-se, por exemplo, que a absorção percutânea após imersão de ambas as mãos durante 15 minutos em xileno produziu concentrações de xileno no sangue aproximadamente iguais às obtidas após a inalação de 100 ppm para o mesmo período de tempo (Engstrom et al., 1977). Esta absorção através da pele depende de:

a) duração do contacto;

b) espessura, perfusão e o grau de hidratação da pele;

c) presença de cortes, abrasões e doenças da pele. (OIT, 2001; Xiao J.Q., 2000; Hartman DE., 2000; Millar JD., et al, 1987). 


\subsection{Distribuição e transformação}

Após absorção, os solventes orgânicos passam pela biotransformação (principalmente produzida no fígado), ou acumulam-se nos tecidos ricos em lípidos, tais como o sistema nervoso. O metabolismo hepático geralmente consiste em reações mistas oxidativas catalisadas pelo sistema citocromo $\mathrm{P}$ 450, seguido pela conjugação com ácido glucurónico, ácido sulfúrico, glutatião, ou glicina. Metabolismo geralmente resulta na desintoxicação de solventes orgânicos através da formação de compostos solúveis em água que são excretados através da urina ou bílis. No entanto, o metabolismo também pode produzir metabolitos intermediários reativos que são mais tóxicos do que 0 composto original. Estes metabolitos são capazes ligar-se através de ligações covalentes a macromoléculas essenciais (por exemplo, proteínas, DNA e RNA) e produzir efeitos tóxicos. A ingestão aguda de etanol no sangue aumenta as concentrações tolueno e xileno, através da competição para o metabolismo, enquanto a ingestão crónica de etanol induz enzimas de solventes e, por conseguinte, diminui as concentrações sanguíneas de solvente. Os locais de trabalho onde há exposição simultânea a vários solventes ou misturas deles, podem levar a interações metabólicas similares (OIT, 2001; Xiao J.Q., 2000; Hartman DE., 2000; Millar JD., et al, 1987). 


\subsection{Eliminação}

A eliminação dos solventes ocorre por meio da exalação do composto no ar expirado ou por meio da excreção urinária ou biliar dos metabolitos solúveis em água (OIT, 2001; Xiao J.Q., 2000; Hartman DE., 2000; Millar JD., et al, 1987).

\subsection{Neurotoxicidade, carcinogenicidade e as manifestações na saúde}

Pode definir-se como neurotoxicidade a capacidade de induzir efeitos adversos no sistema nervoso central (SNC), sistema nervoso periférico (SNP) e órgãos dos sentidos e aos produtos químicos neurotóxicos como aqueles que são capazes de induzir um modelo definido constante de disfunção nervosa através da sua nocividade na estrutura química do SNC.

A neurotoxicidade pode expressar-se através de efeitos agudos ou crónicos e os seus sintomas e consequências variam de acordo com o tempo de exposição, agressividade da substância, dose e a sensibilidade individual do trabalhador. Algumas manifestações de alteração ou mesmo lesões do sistema nervoso são:

- perda da visão;

- perda de audição;

- perda de olfato;

- diminuição da capacidade para controlar os movimentos;

- diminuição da capacidade de armazenar e interpretar informações;

- distúrbios comportamentais ou psicológicas. 
As alterações de humor ou de personalidade são uma ocorrência comum após lesões cerebrais (OIT, 2001; Xiao JQ., 2000).

Os danos do SNC causadas por substâncias neurotóxicas não são facilmente reconhecidas por meio de métodos convencionais de diagnóstico clínico, e as suas manifestações são expressas de forma variada de distúrbios da função neuropsicológica (OIT, 2001).

Os métodos de estudo dos efeitos neurotóxicos sobre o sistema nervoso central e periférico procuram superar as dificuldades colocadas por manifestações discretas e subclínicas, falta de seletividade de afeção das substâncias por um sistema ou nível neurológico e a correlação com um nível de exposição específico, mediante a utilização de medições sensíveis dos efeitos produzidos (OIT, 2001).

Os pintores são expostos a uma vasta gama de misturas complexas que incluem um certo número de produtos químicos carcinogénicos e mutagénicos incluindo solventes orgânicos e de corantes. Os resultados de um estudo realizado na Nova Zelândia são consistentes com trabalhos anteriores mostrando um aumento do risco de cancros urológicos e hemáticos entre pintores. O estudo constatou um excesso de casos de múltiplos mielomas entre os pintores (Bethwaite, P., 1990). 


\subsection{Caraterísticas toxicocinéticas e dinâmicas do tolueno}

O tolueno é um líquido límpido, incolor com um odor característico. É um bom solvente (uma substância que pode dissolver outras substâncias). O tolueno é utilizado na fabricação de tintas, diluentes de tintas, esmalte de unhas, vernizes, adesivos e borracha, solvente de limpeza e, em alguns processos de impressão e de curtimento de couro. Pode notar-se o cheiro no ar a partir duma concentração de 8 partes de tolueno por milhão de partes de ar (ppm), e gosto na água com uma concentração compreendida entre 0,04 e 1 ppm. Ao trabalhar com os materiais que o contem, este evapora-se e mistura-se no ar que se respira (Agency for Toxic Sustances and Disease Registry (ATSDR), 2007).

A exposição ao tolueno pode ocorrer de diversas formas, incluindo, água, alimentos, ar e produtos de consumo. O local de trabalho pode ser a principal fonte de contaminação com tolueno quando os trabalhadores estão expostos a materiais que o contem na sua composição, principalmente, se as medidas de prevenção adotadas não forem as mais adequadas. $O$ tolueno pode entrar no organismo através da respiração dos seus vapores, comer alimentos ou água contaminados. Quando há exposição a produtos que contem tolueno nas várias formas de aplicação, este, também pode penetrar através da pele e entrar na corrente sanguínea. Após a entrada no organismo, mais de $75 \%$ é removido em 72 horas. A maioria do tolueno inalado ou ingerido é eliminado na urina dentro de 12 horas após a exposição. Uma pequena quantidade (até 20\%) é excretada no ar expirado como uma solução de tolueno livre e menos de $2 \%$ do total de metabolitos são excretados na bílis (Tolueno ATSDR, 2000).

Depois de uma única exposição, a remoção de tolueno e os seus metabolitos é quase completa em 24 h (Stellman et al, 2001; Horowitz, 2001).

Geralmente, o organismo transforma o tolueno em produtos químicos menos nocivos, tais como ácido hipúrico (Agency for Toxic Substances and Disease Registry (ATSDR), Toluene, 2000). Além do ácido hipúrico, outro 
metabolito resultante da transformação do tolueno no organismo são os isómeros de o-Cresol na urina (Figura 1).

De acordo com as recomendações da ACGIH - American Conference of Governmental Industrial Hygienists e transpostas para a norma NP 1796 de 2014 os metabolitos do tolueno passaram a ser, tolueno no sangue com um valor limite biológico (VLB) de 0,02 mg/L, tolueno na urina com VLB de $0,03 \mathrm{mg} / \mathrm{L}$ e oCresol na urina com VLB de $0,3 \mathrm{mg} / \mathrm{g}$ de creatinina.

O Tolueno pode causar dores de cabeça e sonolência, e pode prejudicar a capacidade de raciocínio. Os efeitos estão dependentes da quantidade que entra no organismo, tempo de exposição, suscetibilidade genética e idade. Uma baixa ou moderada exposição no local de trabalho, dia após dia, pode provocar cansaço, confusão, fraqueza, efeito tipo embriaguez, perda de memória, náuseas e perda de apetite. Estes sintomas geralmente desaparecem após cessar a exposição. A após exposição crónica ao tolueno, os efeitos neurológicos mais frequentes são manifestados em:

- a) distúrbios cognitivos, tais como confusão, demência e disfunção mental;

- b) transtornos neuropsiquiátricos, tais como labilidade emocional, psicose, encefalopatias, insónia e alterações de personalidade;

- c) alterações dos nervos cranianos, como anosmia, distúrbios oculomotores, neurossensorial da audição, alterações do nervo ótico e da função vestibular;

- d) a nível cerebelar, ataxia, disartria, nistagmo e sinais piramidais;

- e) disfunção do sistema nervoso periférico e autónomo: debilidade persistente (laxitude), alteração da função neuromuscular, e neurastenia (OMS, 1985; Horowitz, 2001; ATSDR Tolune, 2000).

As alterações hepáticas podem provocar desde a disfunção hepática subclínica até necrose hepática maciça. Em trabalhadores com exposição prolongada podem ser observadas alterações como: 
- hepatomegalia;

- aumento do tempo de protrombina;

- esteatose hepática não alcoólica;

- insuficiência hepática aguda;

- aumento do risco de tumores hepáticos primários (Bosia, 2005).

A extensão dos danos no fígado depende da dose, duração da exposição, atividade e metabolismo das enzimas hepáticas e suscetibilidade individual (Farrell, 2002).

Efeitos cardiovasculares, tais como arritmias cardíacas incluindo contrações prematuras multifocais e taquicardias supraventriculares, foram relatados. Estes efeitos podem ser devidos a perturbações eletrolíticas, hipoxia e acidose causadas por hipoventilação mediada pelo sistema nervoso central ou pela toxicidade direta sobre as células cardíacas (Horowitz, 2001; ATSDR Tolueno, 2000).

Em relação ao sistema músculo-esquelético, o tolueno pode provocar efeitos tóxicos diretos sobre a membrana muscular. A hipocalemia e hipofosfatemia podem causar fraqueza muscular. Casos de rabdomiólise também podem ocorrer (Horowitz, 2001).

A natureza lipofílica do tolueno permite que passe facilmente através da placenta. $O$ atraso no desenvolvimento e crescimento intrauterino, parto prematuro, (Donald, 1991) anomalias congênitas, morte perinatal e neonatal acidose têm sido associados com o abuso de tolueno durante a gravidez. As embriopatologías como microcefalia, características dismórficas craniofaciais e atraso de desenvolvimento têm sido descritos por inalação de tolueno durante a gravidez (Horowitz, 2001).

Foram encontrados dados compatíveis com um ligeiro aumento no risco de cancro retal associado à exposição de tolueno, embora seja sugerido o ajuste 
a outros fatores de risco no trabalho que podem interferir nos resultados (Dumas S. et al., 2000).

Uma inalação de uma grande quantidade de tolueno num curto espaço de tempo pode provocar tonturas, sonolência e provocar desmaios. Se esta exposição continuar pode provocar a morte. Se a exposição for interrompida as tonturas e a sonolência desaparecem, no entanto, se persistir, pode provocar danos cerebrais permanentes. Além disso, os problemas com a fala, visão, audição, perda do controle muscular, perda de memória, falta de equilíbrio, e diminuição da capacidade mental podem ser permanentes (ATSDR Toluene, 2000; International Agency for Research on Cancer, IARC (1999a). O tolueno (em níveis elevados) pode danificar os rins. A conjugação da exposição ao tolueno com o facto de beber bebidas alcoólicas pode afetar o fígado de uma forma sinérgica, ou seja, a afeção é superior ao somatório dos seus efeitos isolados (ATSDR, 2000).

A natureza lipofílica do tolueno pode resultar em lesões com preferência no sistema de fibras mielinizadas, tecido rico em lípidos no sistema nervoso central, os quais são pelas suas características relativamente estáveis podem provocar sequelas neurológicas prolongadas ou permanentes (Horowitz, 2001).

A combinação de tolueno e alguns medicamentos comuns, como aspirina e paracetamol pode aumentar os efeitos de tolueno sobre a audição (ATSDR, 2000).

Os efeitos do tolueno exercem-se fundamentalmente no sistema nervoso central, fígado, rins e pulmões (ATSDR, 2000). 


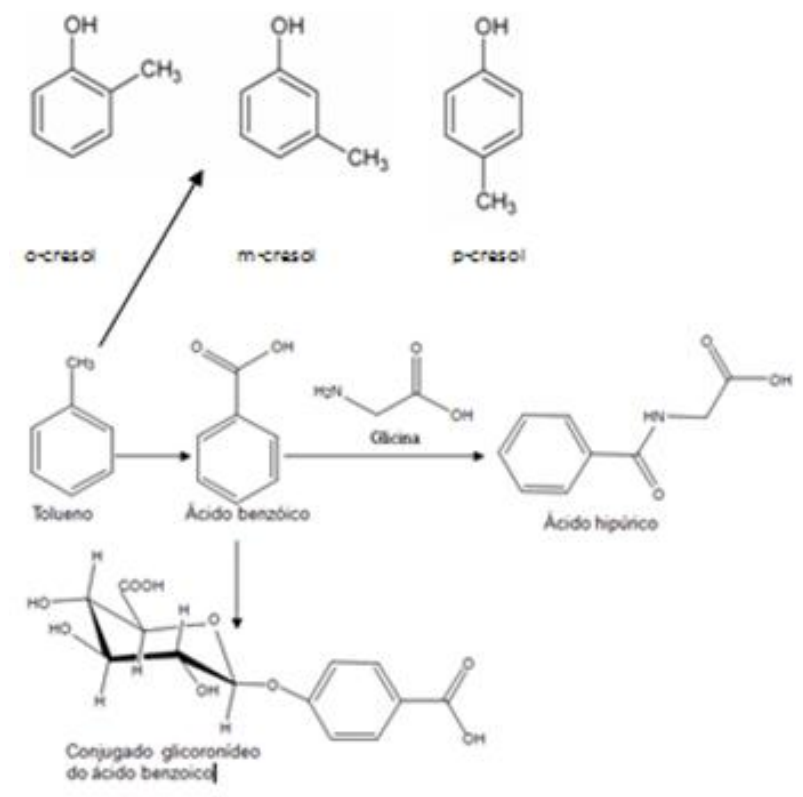

Figura 1 - Biotransformação do tolueno (Adaptado de Randal, Craig and Creavey, Robert. 2002) 


\subsection{Caraterísticas toxicocinéticas e dinâmicas do xileno}

O xileno pode apresentar-se em três formas, em que os grupos metilo variam no anel de benzeno: meta-xileno, orto-xileno, para-xileno ( $\mathrm{m}$-, o- e pxileno). Estas diferentes formas denominam-se por isómeros.

Quando a literatura indica xilenos totais refere-se a todos os isómeros ( $\mathrm{m}$-, o- e p-xileno). A mistura de xilenos é composta pelos três isómeros e geralmente também contém 6-15\% etilbenzeno (Agency for Toxic Substances and Disease Registry (ATSDR, Xylene, 2007). O xileno também é conhecido como xilol ou dimetilbenzeno.

O xileno é um líquido incolor com um odor doce que é facilmente inflamável. Pode ser encontrado naturalmente no petróleo e alcatrão. A nível industrial é produzido a partir do petróleo.

É utilizado principalmente como um solvente nas indústrias de impressão, borracha e couro. Junto com outros solventes, o xileno também é amplamente usado como um agente de limpeza, diluente de tinta e em vernizes. O xileno é usado, em menor extensão, na indústria química, plásticos e fibras sintéticas. Isómeros de xileno são utilizados no fabrico de alguns polímeros para o fabrico de plásticos. O xileno é encontrado em pequenas quantidades no combustível de avião e na gasolina (ATSDR, Xylene, 2007). Em alguns estudos, tem-se salientado a importância da exposição destes compostos orgânicos voláteis em consumíveis, principalmente em ambientes domiciliares (cola, tintas, esmaltes, vernizes) que podem produzir uma concentração maior que $1000 \mathrm{mg} / \mathrm{m}^{3}$ (Croute, et al., 2002). Após ser transformado, os produtos químicos e petroquímicos resultam em embalagens, perfumes, mobiliário, materiais de construção (cimento), vestuários, calçados, componentes industriais (indústria eletrónica de informática, automobilística e aeronáutica) tintas, produtos de limpeza, corantes, medicamentos, químicos agrícolas e fertilizantes, óleo de imersão para a microscopia, vernizes, agentes clarificadores para cortes histológicos, matériaprima para a produção do ácido benzóico, anidrido ftálico, ácido isoftálico e éster dimetil (Beasley 1992; Riihimaki et al., 1982b). O xileno é um produto 
imprescindível para a realização de exames de anatomia patológica e citologia (Dias-Teixeira, M., 2009). A função deste é de tornar os tecidos translúcidos, participando da etapa de clareamento ou diafanização destes (Junqueira \& Carneiro 2004).

O vapor de xileno é rapidamente absorvido nos pulmões e na forma líquida é lentamente absorvido através da pele (Riihimaki \& Pfaffli, 1978). A absorção pulmonar de vapores é semelhante para todos os isómeros de xileno. Sensivelmente $60-65 \%$ do xileno inalado é absorvido (Ŝedivec, 1976). A capacidade de retenção não varia com a intensidade e duração da exposição mas sim com a capacidade de ventilação (Lauwerys, 1994; Ŝedivec,1976). As propriedades lipofílicas possibilitam a passagem através da membrana alveolar e a sua acumulação no sistema nervoso central (Horowitz, 2001). O xileno absorvido, 95\% é metabolizado no fígado a ácidos metilbenzoicos (Langman, 1994). Estes ácidos conjugam-se com a glicina para formar o ácido orto, meta ou para-metilhipúricos (Figura 2), que são excretados através da urina (Lauwerys, 1994; Ogata, 1970). Cerca de $70-80 \%$ dos metabolitos são excretados na urina em $24 \mathrm{~h}$ (Langman, 1994). Apenas 3 a 6\% é excretado e inalterado no ar exalado. O tempo médio de eliminação é acima das 20 a 30 horas (Lauwerys, 1994).

A exposição aguda ao xileno causa irritação nos olhos, mucosas das vias respiratórias e sintomas de depressão do sistema nervoso central abrangendo narcose, anestesia, euforia, tonturas, ataxia e cefaleia. Outros efeitos incluem distúrbios da articulação para a palavra, confusão, perda de memória temporária, desorientação, tremores e irritabilidade. As depressões do sistema nervoso central podem resultar em letargia, insuficiência respiratória e morte em muitos casos (Stellman et al., 2001; Horowitz, 2001).

Efeitos gastrointestinais, como náuseas, vómitos, hematemese e dores abdominais são queixas comuns em pacientes submetidos à exposição aguda por inalação a xileno. Valores elevados transitórios dos testes da função hepática também foram relatados (Horowitz, 2001; Stellman et al., 2001). 
Uma exposição ocupacional crónica ao xileno tem sido associada a disfunção neuropsicológica, anemia, trombocitopenia, leucopenia, dispneia, e cianose (Langman, 1994). No sistema nervoso manifesta-se por fraqueza geral, tonturas, dor de cabeça, irritabilidade, insónia, fadiga extrema, tremores, incapacidade de concentração, perda de memória a curto prazo e zumbido nos ouvidos. O contato direto nos olhos causa irritações, conjuntivite e danos à córnea e na pele pode causar alterações, em particular o eczema (Stellman, et al., 2001), irritações e dermatites (Beasley, 1992; Merck \& CO 1995; Trujillo et al., 2003).

As mulheres podem sofrer alterações dos ciclos menstruais manifestando menorragia ou metrorragia. Durante a gravidez pode provocar toxicose, risco de aborto e hemorragias durante o parto além de poder causar esterilidade (Horowitz, 2001; Stellman et al., 2001).

A inalação do tolueno ou xileno podem induzir distúrbios fonológicos, visuais, auditivos, motores além de poder estar relacionado com o surgimento de tumores cerebrais e leucemias linfocíticas quando associado ao benzeno (Irwin et al. 1997; Tiburtius et al. 2004).

Subsiste uma pequena evidência que o xileno em altas doses é carditóxico em humanos. Um estudo efetuado mostrou que, em 5 dos 25 homens hospitalizados após terem o contato com tinta foram detetadas arritmias e contrações ventriculares prematuras multifocais (Streicher et al., 1981).

Num estudo efetuado nos Estados Unidos da América foi descoberto um aumento da mortalidade devido a linfomas entre os trabalhadores de mobiliário de madeira, quando expostos ao xileno e outros solventes orgânicos (Miller, B.A. 1989). Um pequeno excesso de linfossarcoma foi relatado entre os trabalhadores de borracha expostos ao xileno (Wilkosky, T.C. et al., 1984) e o aparecimento de linfomas foi elevado entre os trabalhadores expostos a solventes orgânicos e clorofenóis (Hardell, L. et al., 1981; Vianna, N.J. et al., 1979).

O xileno não está classificado como um agente carcinogéneo nos humanos e poucos estudos epidemiológicos tem sido feitos em relação a esta 
substância isoladamente. Segundo Rego (1999), os trabalhadores que manuseiam com produtos químicos em geral estão mais expostos a substâncias carcinogéneas e isso tem sido considerado um dos maiores riscos aos seres humanos. A exposição ocupacional a solventes orgânicos pode contribuir para o aparecimento dos Linfoma não-Hodgkin e que o sinergismo com outros fatores pode constituir um relevante aspeto do processo de linfomagenese (Rego, 1999).

O xileno em concentrações de 200 ppm ou superiores produz irritação nas membranas e mucosas, náuseas, vómitos, tonturas e falta de coordenação. As concentrações de xileno no sangue acima de $3 \mathrm{mg} / \mathrm{L}$ são produzidas pela exposição sedentária de indivíduos a 300-400 ppm de xileno (Savolainen et al., 1979).

Concentrações no ar superiores a 10.000 ppm de xileno têm causado inconsciência em trabalhadores devido à depressão do sistema nervoso central, até à morte (Morley, et al., 1970).

O xileno em estudos comparativos, afetou os limiares auditivos em frequências mais baixas que o tolueno e foi detetada uma perda de sensibilidade auditiva nas frequências médias em todos os estudos (Gagnaire F., Brigitte $M$, Langlais C., Pierre P., 2000). Na Austrália, e na Nova Zelândia o xileno é considerado na legislação como um agente ototóxico industrial (AS/NZS1269.0:2005). Em 2004, o governo australiano recomendou que a exposição diária ao ruído dos trabalhadores expostos a solventes fosse reduzida para valores inferiores a $80 \mathrm{dBA}$, e que fossem efetuados regularmente testes audiométricos. 


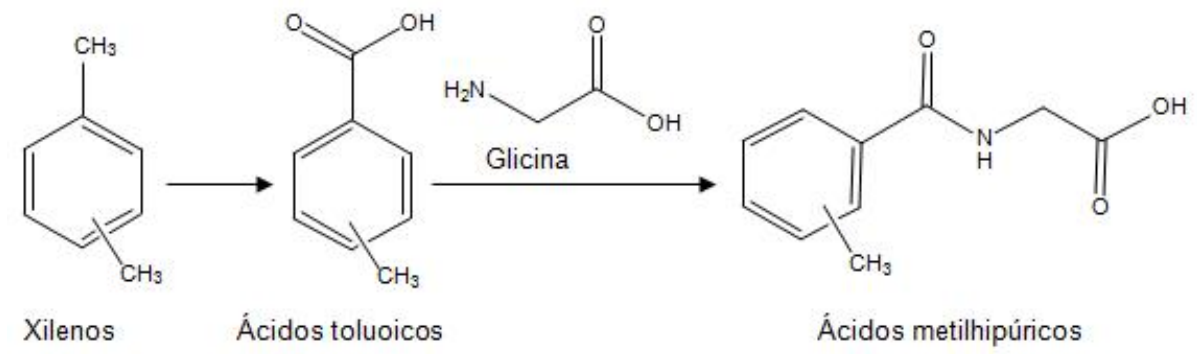

Figura 2 - Biotransformação do xileno. (Adaptado de Randal, Craig and Creavey, Robert. 2002) 


\subsection{Caraterísticas toxicocinéticas e dinâmicas do etilbenzeno}

O etilbenzeno é um líquido inflamável incolor e com odor semelhante à gasolina. Está presente em produtos naturais, tais como o carvão e petróleo, bem como na fabricação de produtos tais como tintas, inseticidas e vernizes (ATSDR, Etilbenceno, 1999).

O seu comportamento toxicocinético é muito semelhante ao xilenos, é preferencialmente absorvida por inalação, no entanto, por ingestão também provoca uma absorção rápida e eficiente. $\mathrm{A}$ absorção pela pele é mais lenta. $\mathrm{O}$ etilbenzeno tem uma baixa toxicidade em animais e no homem, tanto nas exposições agudas como crónicas. Os seus principais efeitos tóxicos ocorrem no sistema nervoso central, que funciona como um depressor. É também um irritante das mucosas, olhos e sistema respiratório (Moreno Gray, 2003).

A exposição ao etilbenzeno a uma concentração de 1000 ppm no ar, provoca irritação dos olhos e do nariz. Em concentrações de 2000 ppm ou superior pode causar lacrimejamento, tonturas e depressão do sistema nervoso central (Lewis, R., 1998; Randal, C. and Creavey, R., 2002).

O etilbenzeno é metabolizado dentro do corpo humano, por oxidação da cadeia alifática em metilfenilcarbinol. A oxidação deste primeiro metabolito produz ácidos mandélico e fenilglioxilico, as quais representam 64 e $25 \%$, respetivamente, de uma dose inalada de etilbenzeno e subsequentemente excretados na urina (Figura 3). Apenas uma pequena parte da dose é excretada sem ser metabolizada através do ar expirado e na urina (Randal, C. and Creavey, R., 2002).

A excreção urinária de ácido mandélico alcança um máximo durante as últimas 2 horas de uma exposição de 8 horas, e depois decai com o tempo de vida médio de 4-7 horas após o fim da exposição. A concentração de ácido mandélico determinado na urina dos trabalhadores expostos ao etilbenzeno, a uma concentração de 92 ppm na atmosfera durante oito horas, foi de 900 ppm (Randal, C. \& Creavey, R., 2002). 
Efetuou-se um estudo onde se detetou que o etilbenzeno líquido, tanto puro como dissolvido é absorvido pela pele intacta de voluntários (Dutkiewicz, et al., 1967). A taxa média de absorção de etilbenzeno líquido aplicado sobre uma superfície de $17,3 \mathrm{~cm}^{2}$ do antebraço de sete voluntários durante 10-15 minutos foi de $38 \mathrm{mg} / \mathrm{cm}^{2} / \mathrm{h}$. Os investigadores concluíram que o índice de absorção através da pele é superior a outras substâncias, tais como, anilina, benzeno, nitrobenzeno, sulfureto de carbono e estireno.

Num estudo relativo á exposição dérmica de vapores de etilbenzeno (1300 mg/m $/ \mathrm{m}^{3}$ ou $300 \mathrm{ppm}$ ) durante duas horas entre $90 \%$ a $95 \%$ da sua pele a vapores de etilbenzeno, não revelou um aumento do ácido mandélico, que é o principal metabolito do etilbenzeno na urina (Gromiec et al., 1984).

A absorção do etilbenzeno através dos pulmões de indivíduos expostos a concentrações de cerca de 100 a 200 ppm durante 8 horas foi investigada por Bardodej e por Bardodejova (1970). Esses autores descobriram que para um estado de retenção (equilíbrio), entre $45 \%$ e $50 \%$ do etilbenzeno inalado é retido. Um segundo estudo obteve um valor ligeiramente mais elevado, 65\% (Gromiec et al., 1984).

O etilbenzeno tem propriedades anestésicas em níveis elevados de exposição, sugerindo que os efeitos sobre o sistema nervoso central também serão importantes para níveis mais baixos (Yant et al., 1930). Foram detetadas alterações nos níveis de noradrenalina e dopamina no hipotálamo de ratos expostos a $2.000 \mathrm{ppm}(8.840 \mathrm{mg} / \mathrm{m} 3)$ de etilbenzeno durante 6 horas/dia em três dias (Anderson et al., 1981), embora não se tenham observado alterações comportamentais.

Não há praticamente nenhuma informação sobre os efeitos tóxicos de etilbenzeno puro em seres humanos, uma vez que a exposição ocorre normalmente em combinação com outros solventes. No tocante a composição de tintas, vernizes e tapa poros para o sector do mobiliário as percentagens normais rondam os 2 a $5 \%$.

Relatou-se que o nível de exposição de 200 ppm é irritante (Ruth, 1986). Estima-se que a concentração de etilbenzeno inalado necessária para deprimir 
em $50 \%$ a frequência respiratória é de aproximadamente 1430 ppm durante um período de cerca de cinco minutos (De Ceaurriz et al., 1981).

Ivanov (1964) apresentou os resultados de um estudo de trabalhadores industriais exposto unicamente a etilbenzeno num nível máximo de 14 ppm. A maioria dos trabalhadores queixaram-se de dores de cabeça, irritabilidade e cansaço rápido. Detetaram-se alterações no sistema nervoso funcional trabalhadores que trabalhavam há mais de sete anos. Além disso, alguns trabalhadores mostraram aumento do tamanho do fígado.

Há evidências de dano coclear em modelos animais expostos a diferentes concentrações de etilbenzeno (Vyskocil et al., 2008b). Destacam-se alterações na resposta a frequências média e baixa, com a perda de células ciliadas externas em ratos, um efeito relacionado com a espécie (Cappaert, Klis, Baretta, Muijser \& Smoorenburg, 2000; Cappaert et al., 2002).

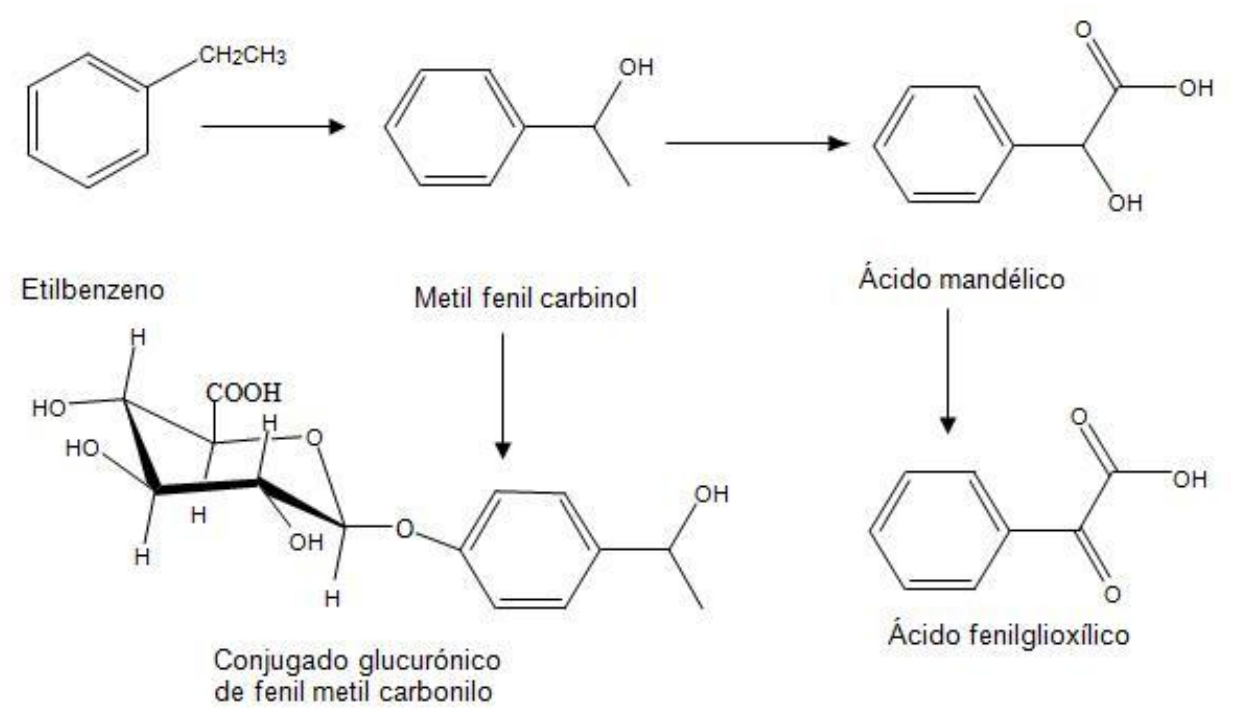

Figura 3 - Biotransformação do etilbenzeno (Adaptado de Cassaret, Luis and Doull, James, 2001 e de Randal, Craig and Creavey, Robert. 2002) 
MATERIAL E MÉTODOS 


\section{Material e Métodos}

O pressuposto que desencadeou a realização deste estudo foi construído a partir de uma preocupação e análise do risco de exposição a COV,s de trabalhadores no fabrico de mobiliário, pelo que se optou por utilizar uma metodologia baseada no estabelecimento de objetivos.

\subsection{Objetivo Geral}

Avaliar a perceção e o risco de exposição ao xileno, ao etilbenzeno e ao tolueno de trabalhadores das empresas de mobiliário.

\subsection{Objetivos Específicos}

Determinar a perceção do risco de exposição ocupacional ao xileno e ao tolueno dos trabalhadores do fabrico de imobiliário.

Quantificar os níveis ambientais de xileno (isómeros e etilbenzeno) e tolueno nas fábricas de mobiliário.

Analisar os indicadores biológicos de exposição ocupacional dos trabalhadores das fábricas de mobiliário ao xileno, tolueno e etilbenzeno. 


\subsection{Metodologia}

Para desenvolvimento deste trabalho, aplicaram-se duas abordagens metodológicas distintas. Inicialmente procedeu-se à aplicação de um questionário (Anexo 8.1) e posteriormente às avaliações da qualidade do ar e biomonitorizações. Obedeceu-se à seguinte ordem de tarefas:

1. Recolha de dados para caracterização da amostra e consequente delimitação do estudo.

2. Desenvolvimento e aplicação de um Questionário teste e aplicação do Questionário final.

3. Medição dos níveis ambientais de tolueno, xileno e etilbenzeno.

4. Quantificação dos indicadores biológicos de exposição ao tolueno, ao xileno, e ao etilbenzeno, e em simultâneo, recolheu-se informação sociodemográfica do trabalhador, caracterização da exposição pessoal ao xileno e ao tolueno, caracterização dos equipamentos de proteção individual.

\subsection{Recolha de dados para a caracterização da amostra}

Os dados sociodemográficos, das empresas, dos trabalhadores, tais como a idade e o género foram obtidos através da aplicação do questionário. 


\subsection{Aplicação dos questionários}

Os questionários são um instrumento de investigação, composto por um número mais ou menos elevado de questões apresentadas por escrito, tendo como objetivo o conhecimento de opiniões, crenças, sentimentos, interesses, expectativas e situações vivenciadas. Trata-se de uma ferramenta de recolha e validação de dados, de suma importância, principalmente quando se está perante variáveis de natureza subjetiva, nomeadamente a perceção do risco, opinião sobre os aspetos de segurança e equipamentos de proteção individual. A construção do questionário foi realizada de um modo estruturado, tendo-se em consideração os itens a estudar, as escalas a adotar e a facilidade de interpretação dos mesmos.

Numa fase inicial, aplicou-se o questionário teste, seguido de um reteste, cujo objetivo foi melhorar a adaptação dos mesmos. Tanto o teste como 0 reteste foram realizados nos meses de fevereiro e março de 2014, respetivamente. Para o efeito, foi selecionada uma amostra sistemática de $40 \%$ do universo de 142 trabalhadores.

O questionário final foi distribuído pessoalmente à população em estudo, nos meses de abril e maio de 2014. Este procedimento permitiu transmitir aos trabalhadores uma garantia de confidencialidade das respostas, através da qual se pretendia minimizar qualquer distorção dos resultados. Este teve uma duração aproximada de 10 minutos, tendo sido devolvidos de imediato.

As informações recolhidas prendem-se com:

- conhecimento do risco dos produtos químicos;

- conhecimento dos produtos químicos utilizados;

- comportamentos na manipulação de produtos químicos;

- perceção do risco da exposição a tintas/velaturas, vernizes e tapa poros;

- utilização de equipamentos de proteção individual; 
- utilização de equipamentos de proteção coletiva;

- efeitos fisiológicos subsequentes à exposição a tintas/velaturas, vernizes e tapa poros;

- interferência do posto de trabalho na exposição;

- frequência de atitudes preventivas;

- formação em matérias de saúde e segurança no trabalho.

A escala opcional adotada baseia-se na metodologia do tipo Likert ( 7 opções), tendo sido adaptada de acordo com a dimensão a avaliar, como se descreve a seguir. Relativamente à codificação das respostas, optou-se por um valor numérico, designado por pontuação, utilizando-se uma escala unipolar de 0 a 6 . 


\subsection{Monitorizações Ambiental e Biológica}

A determinação analítica do tolueno, xilenos, e etilbenzeno, e respetivos metabolitos urinários, foi efetuada no laboratório do Grupo de Reação e Análises Químicas (GRAQ) - Instituto Superior de Engenharia do Porto.

\subsubsection{Amostragem e determinação analítica}

As amostragens foram efetuadas nos postos de trabalho existentes nas zonas de aplicação de tintas/velaturas, vernizes e tapa poros. Esta operação consiste em colocar uma mistura de aditivos (diluentes, secantes, catalisador, etc...) às tintas, vernizes ou tapa poros numa pistola pneumática para projeção de aerossóis sobre as peças de madeira. O operador faz esta mistura, coloca-a no reservatório da pistola ou no contentor de apoio e aplica nas peças. As aplicações podem ser efetuadas em estufa com aspiração de filtros secos (Figura 4, Figura 5 e Figura 6), em cabine com cortina de água (Figura 7, Figura 8 e Figura 9) ou sistemas de aplicação automáticos ou semiautomáticos (Figura 10). Estas aplicações são as necessárias para se dar o acabamento superficial às peças de madeira, assim, conseguem-se produzir peças com diferentes cores, brilhos e texturas. 


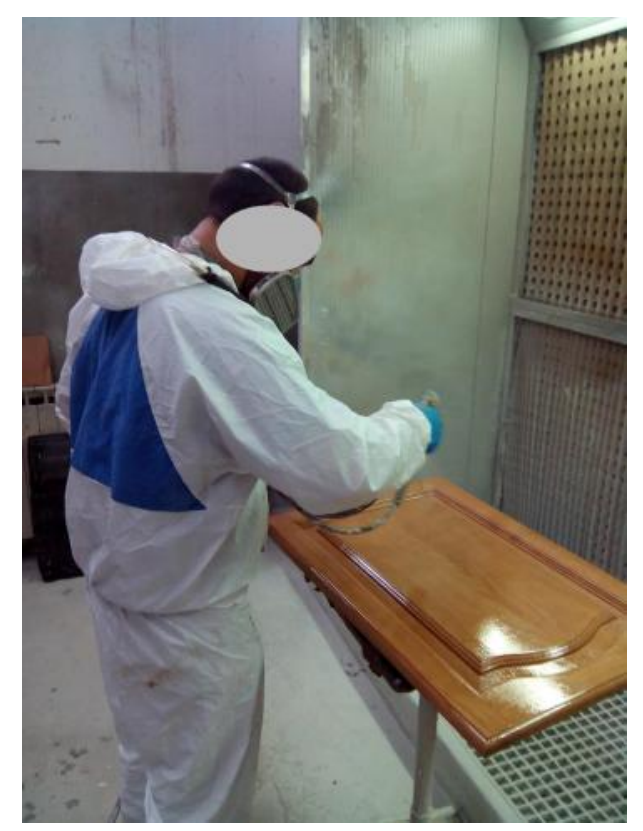

Figura 4 - Aplicação de verniz em cabine de filtros secos

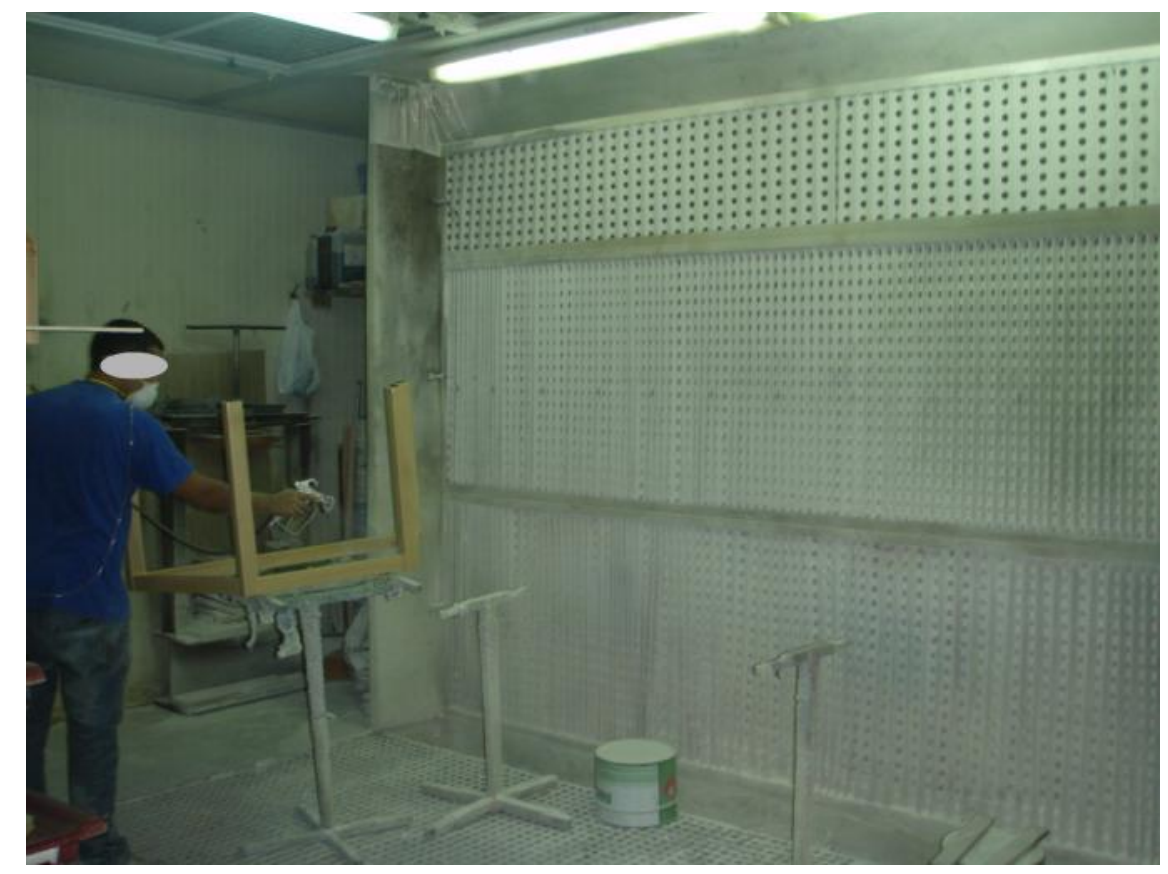

Figura 5 - Aplicação de verniz em cabine de filtros secos 


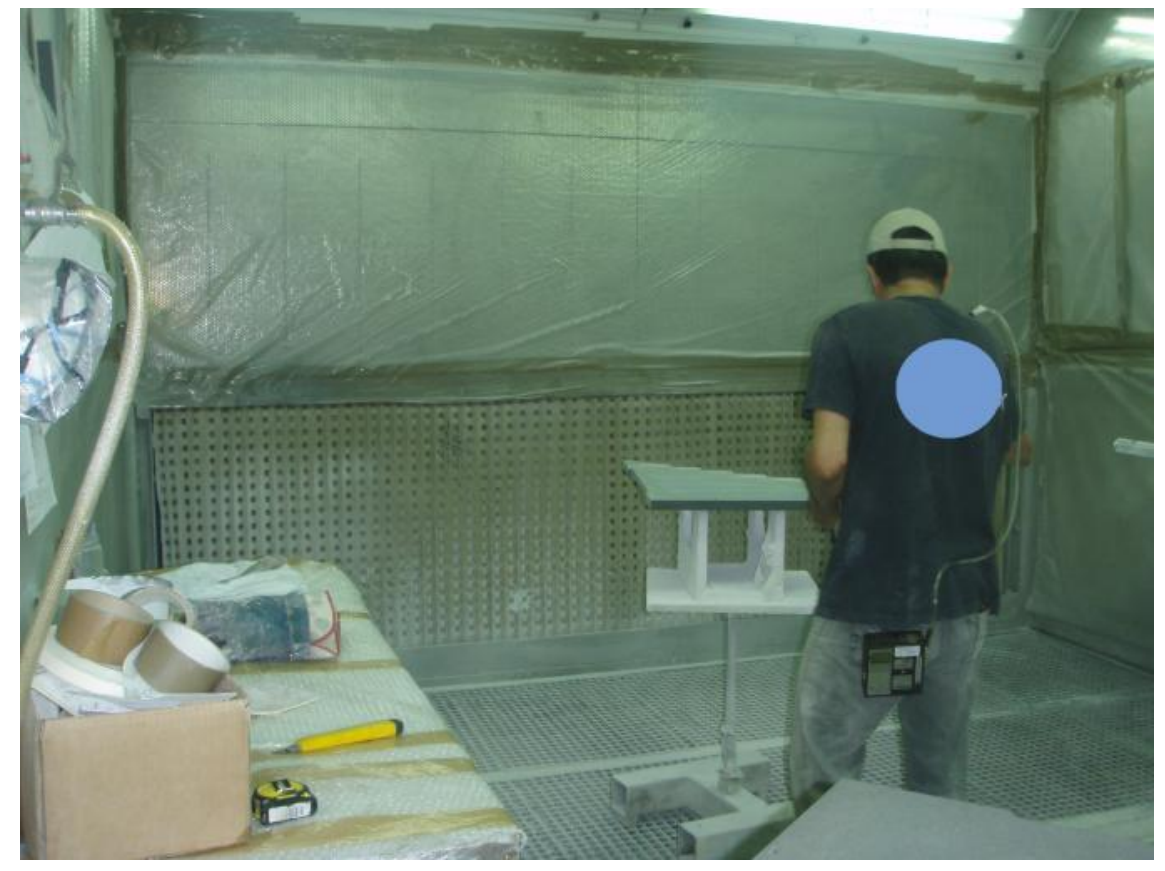

Figura 6 - Aplicação de velatura em cabine de filtros secos

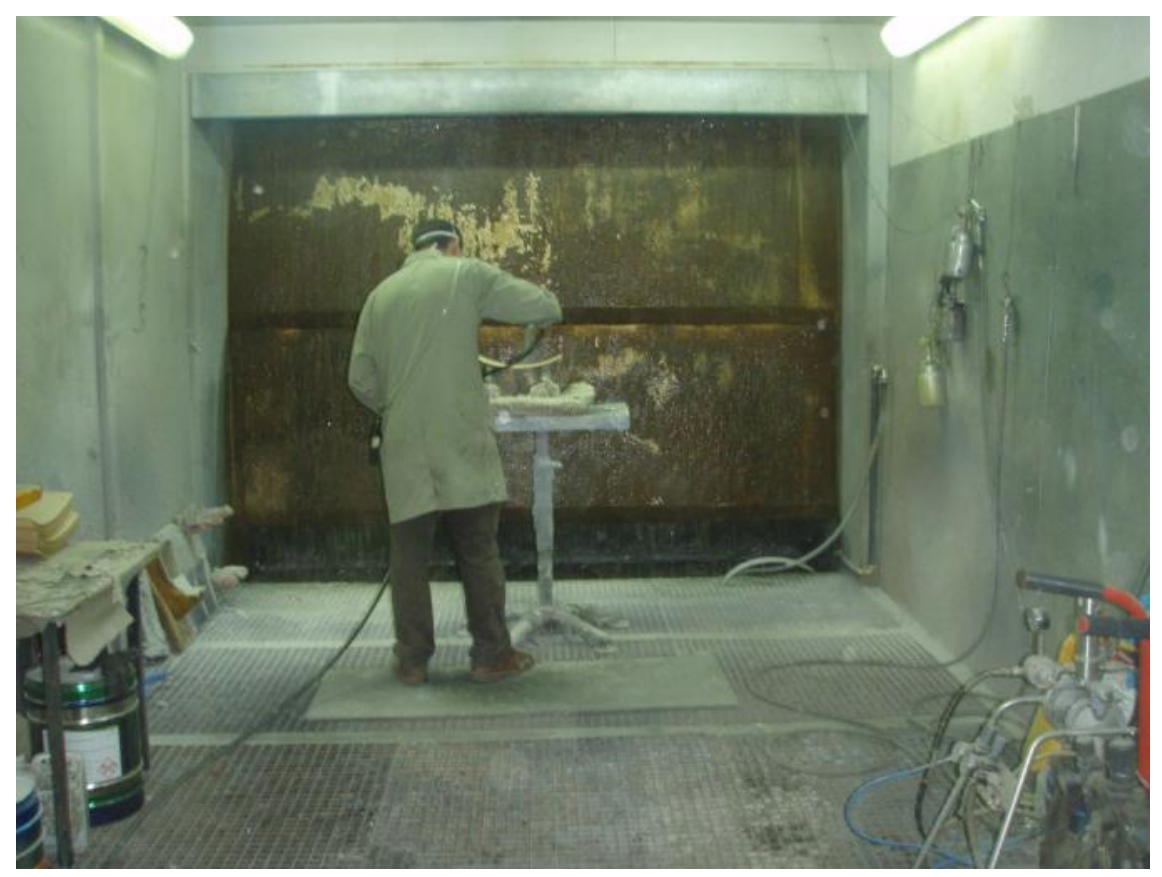

Figura 7 - Aplicação de verniz em cabine de cortina de água 


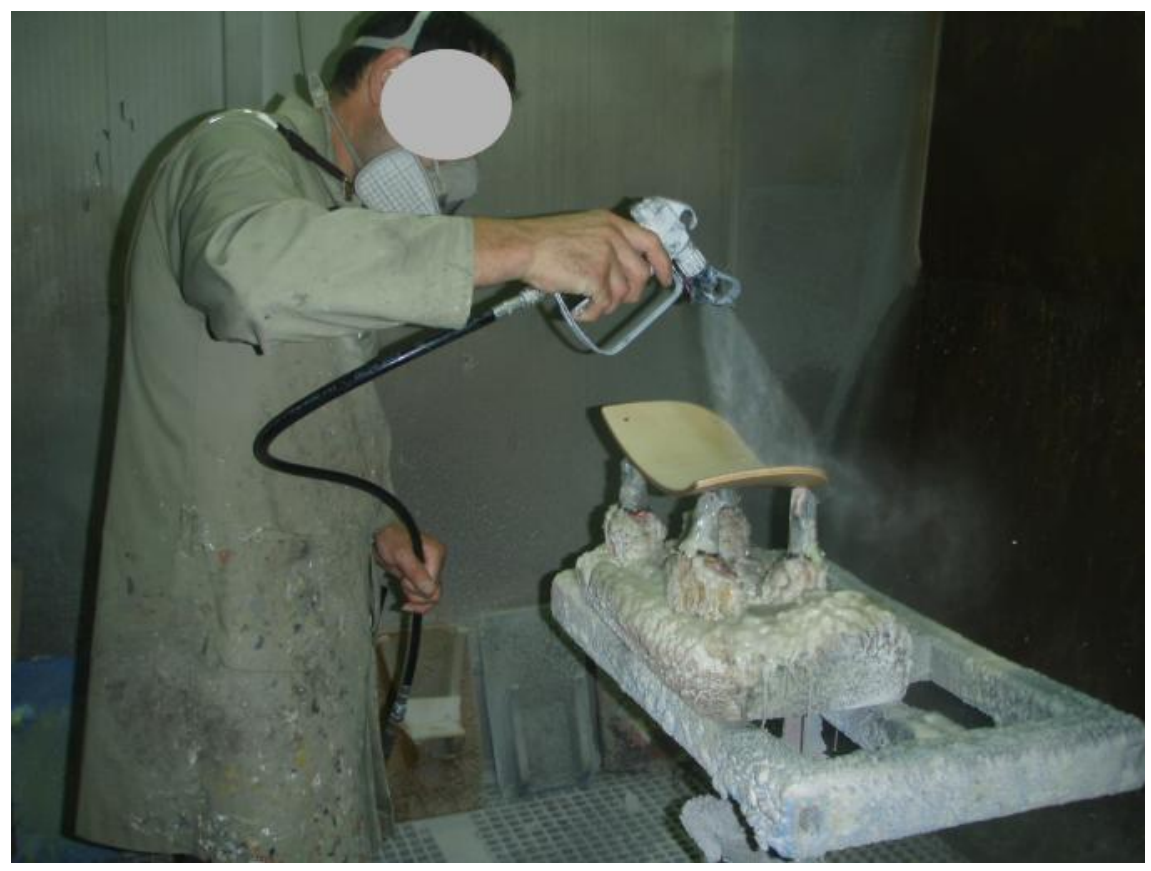

Figura 8 - Aplicação de verniz em cabine de cortina de água

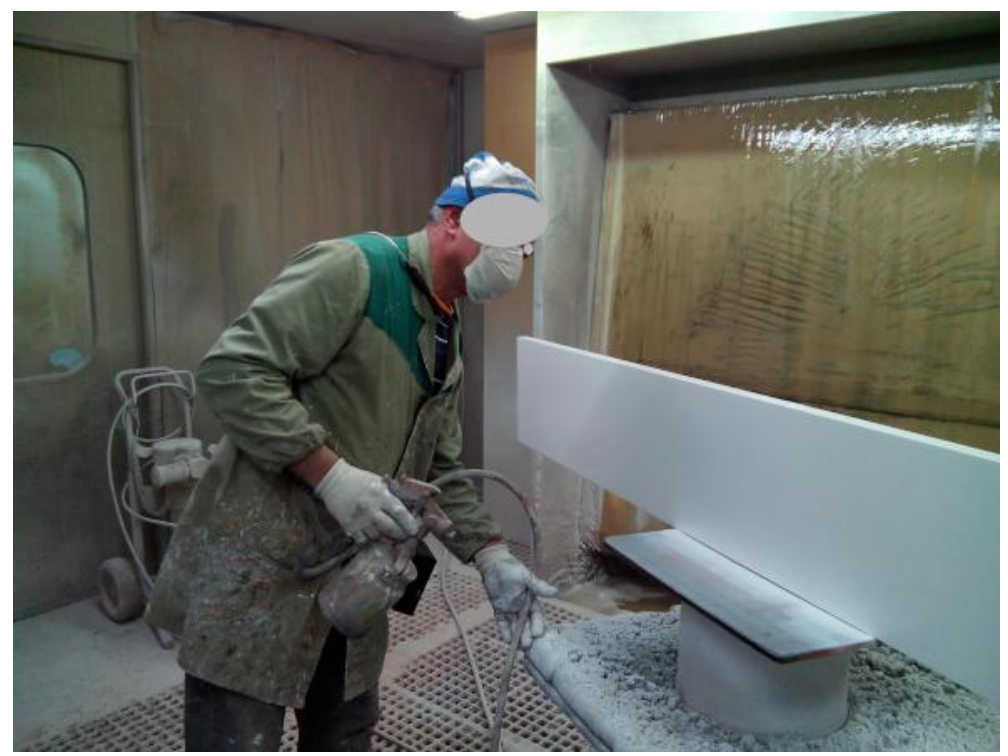

Figura 9 - Aplicação de esmalte em cabine de cortina de água 


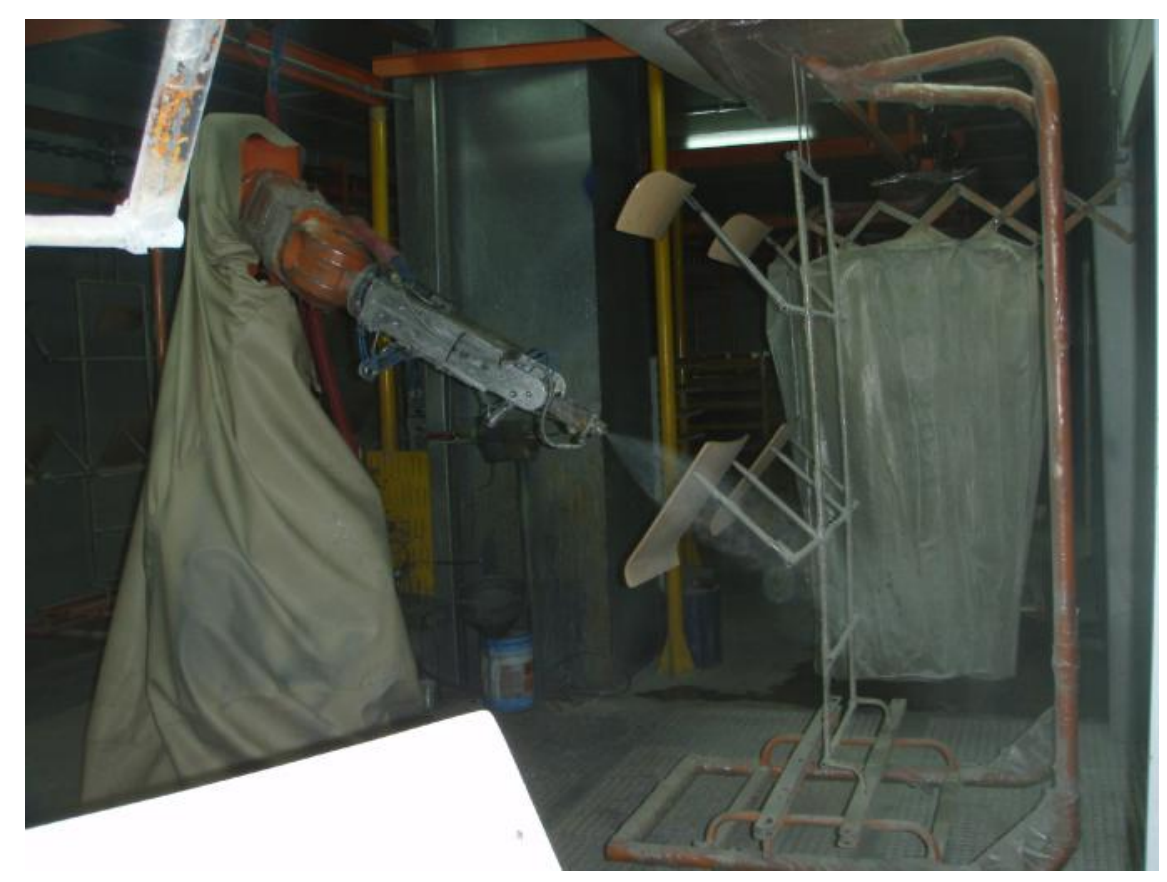

Figura 10 - Aplicação de verniz com robot 


\subsubsection{Ambiental}

As colheitas de ar ambiente foram realizadas entre os meses de Julho e Novembro de 2014. Procedeu-se à recolha de três amostras com recurso a tubos de carvão ativado (SKC - Anasorb® CSC: coconut charcoal, 20/40 mesh, 50/100 mg) ativado (Figura 11, Figura 12 e Figura 13) e a uma bomba de amostragem autónoma (SKC modelo standard - 224-44EX) (Figura 14). Ambas as pontas dos cartuchos foram seccionadas. A taxa de fluxo aplicada variou entre 0,13 e 0,19 L min-1 durante 15 minutos. $O$ amostrador pessoal foi colocado na lapela do trabalhador no qual foi realizada a amostragem de ar na zona de respiração.

O tempo de amostragem (15 minutos) foi controlado com auxílio de um cronómetro (Oregon Scientific).

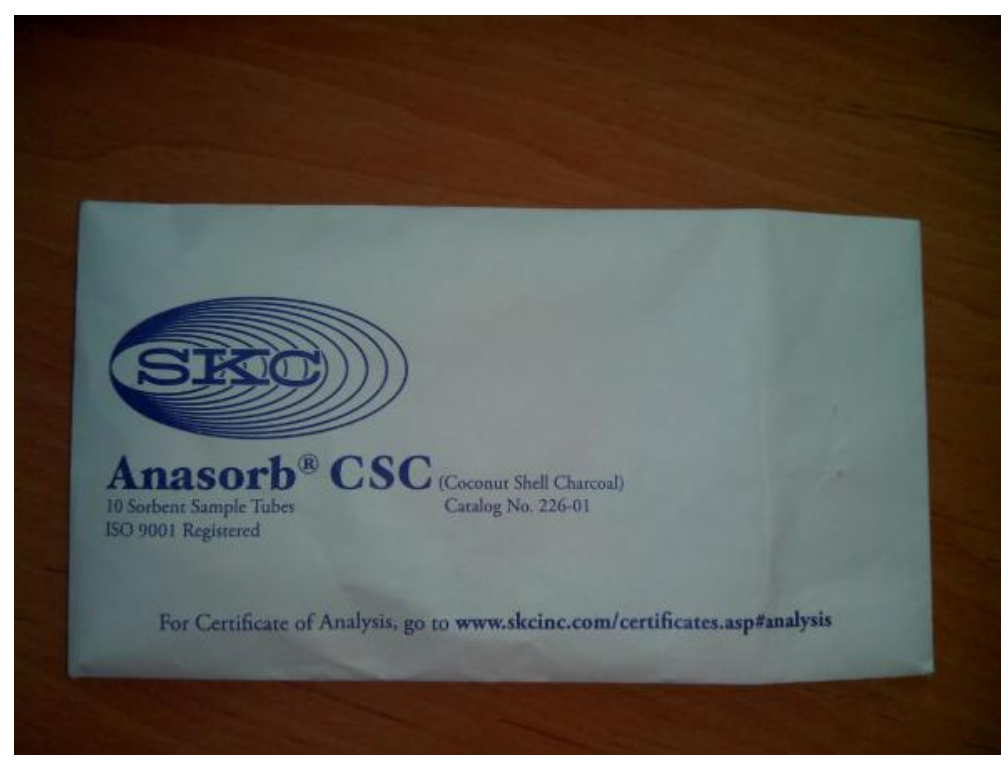

Figura 11 - Embalagem dos tubos de carvão ativado 


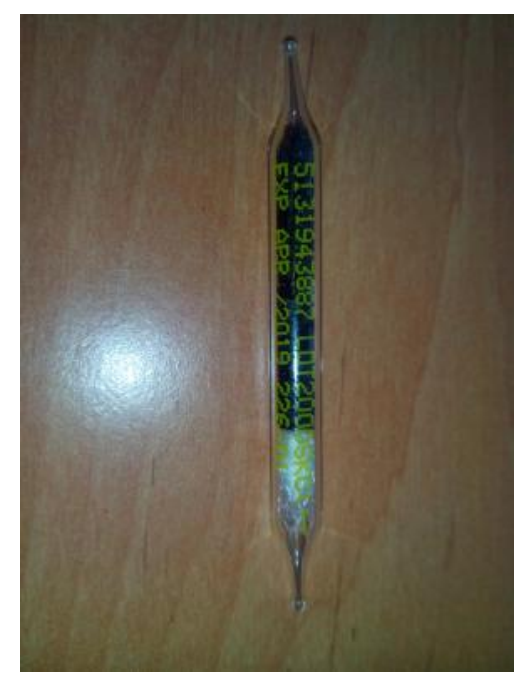

Figura 12 - Tubo de carvão ativado

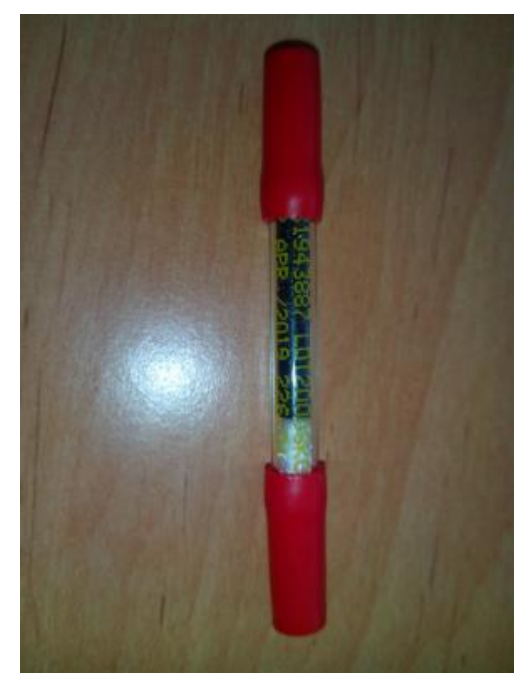

Figura 13 - Tubo de carvão ativado depois de utilizado 


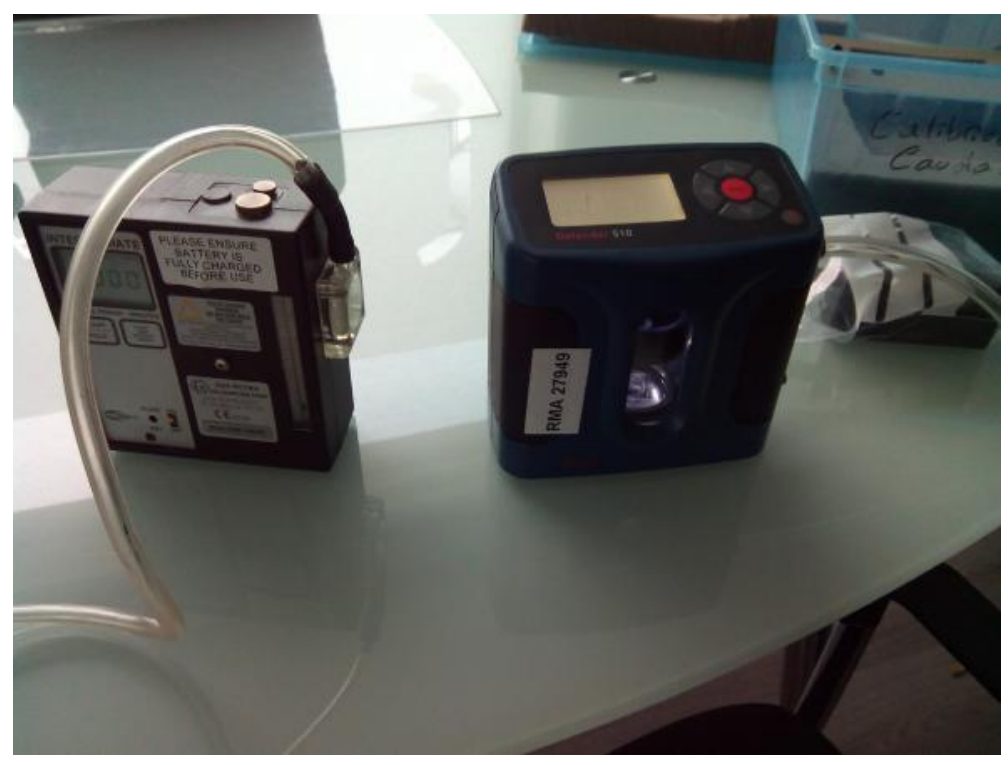

Figura 14 - Bomba de amostragem e respetivo calibrador digital

Realizaram-se 108 colheitas de ar para a determinação de tolueno, xileno e etilbenzeno. Para a determinação analítica das substâncias existentes nas amostras de ar interior nas zonas de aplicação de tintas/velaturas, vernizes e tapa poros, foi realizada por cromatografia gasosa com detetor de ionização de chama (GC-FID), segundo o método NIOSH 1501 (Pendergrass SM, 2003).

Por cada 10 amostras analisadas introduziu-se um branco (controlo de qualidade). 


\subsubsection{Biológica}

A amostragem foi realizada de forma a garantir a representatividade da amostra. As recolhas de urina foram efetuadas para um frasco polipropileno esterilizado de $100 \mathrm{~mL}$ antes e no final do turno de 8 horas diárias. As urinas foram acondicionadas sob refrigeração a $-^{\circ} \stackrel{\circ}{ } \mathrm{C}$ até serem analisadas.

A determinação urinária da creatinina e metabolitos do xileno, tolueno e etilbenzeno foi efetuada por cromatografia líquida de alta precisão com detetor Diode Array (HPLC-DAD) (Dias-Teixeira A et al., 2010; Motock GT, Perkins JB, \& Reynolds JM, 2003).

A determinação do indicador biológico de exposição do tolueno, o-cresol foi efetuada por GC-FID (Amorim LC \& Alvarez-Leite EM, 1997).

Por cada 10 amostras analisadas introduziu-se um branco (controlo de qualidade). 


\subsection{Análise Estatística}

A análise dos dados foi realizada utilizando o software estatístico SPSS para o windows (SPSS Inc, 2012). Para descrever os resultados recorreu-se a ferramentas de estatística descritiva (média e desvio padrão) e inferencial através da aplicação dos testes de Qui-quadrado e de Mann Whitney para análise de associação entre as categorias. O nível de significância adotado para os testes estatísticos foi de $5 \%$, ou seja, $p<0,05$. Foi verificada a consistência interna do instrumento (teste-reteste e questionário final), para isso foi calculado o coeficiente de Cronbach. Considerou-se que para 0 instrumento ser considerado adequado, os valores deveriam ser iguais ou superiores a 0,50, uma vez que este índice tem sido utilizado por investigadores em estudos de validação de escalas. 
RESULTADOS 


\section{Resultados}

Neste capítulo apresentam-se os resultados das monitorizações ambientais e biológicas.

\subsection{Caracterização da Amostra}

Neste estudo participaram 142 trabalhadores de todas as empresas com mais de 15 funcionários dos distritos de Aveiro, Coimbra e Viseu do setor do mobiliário dentro dos códigos de atividade económica 31010 - fabricação de mobiliário para escritório e comércio, 31020 - fabricação de mobiliário de cozinha e 31091 - fabricação de mobiliário de madeira para outros fins.

O universo dos trabalhadores e as respostas aos questionários quanto ao género, idade e habilitações literárias encontram-se na Tabela 2 - Distribuição por sexo dos trabalhadores inquiridos, Tabela 3 - Distribuição por faixa etária dos trabalhadores inquiridos, Tabela 4 - Distribuição por habilitações literárias dos trabalhadores inquiridos e Figura 15 - Número de Trabalhadores segundo as habilitações literárias.

Tabela 2 - Distribuição por sexo dos trabalhadores inquiridos

\begin{tabular}{cccc}
\hline Género & Frequência & Percentagem & $\begin{array}{c}\text { Percentagem } \\
\text { Cumulativa }\end{array}$ \\
\hline Feminino & 79 & 55,6 & 55,6 \\
Masculino & 63 & 44,4 & 100,0 \\
Total & 142 & 100,0 & \\
\hline
\end{tabular}

A taxa de participação no questionário foi de $99,3 \%$, sendo que a amostra global é constituída por $55,6 \%$ de mulheres e $44,4 \%$ de homens (Tabela 2). 
Tabela 3 - Distribuição por faixa etária dos trabalhadores inquiridos

\begin{tabular}{cccc}
\hline & Frequência & Percentagem & $\begin{array}{c}\text { Percentagem } \\
\text { Cumulativa }\end{array}$ \\
\hline $\mathbf{5 2 0}$ & 2 & 1,4 & 1,5 \\
{$[\mathbf{2 1 - 3 0}]$} & 13 & 9,2 & 11,0 \\
{$[\mathbf{3 1 - 4 0}]$} & 38 & 26,8 & 39,0 \\
{$[\mathbf{4 1 - 5 0}]$} & 53 & 37,3 & 77,9 \\
{$[\mathbf{5 1 - 6 0}]$} & 28 & 19,7 & 98,5 \\
$\mathbf{2 6 1}$ & 2 & 1,4 & 100,0 \\
Total & 136 & 95,8 & \\
\hline
\end{tabular}

Tabela 4 - Distribuição por habilitações literárias dos trabalhadores inquiridos

\begin{tabular}{cccc}
\hline & Frequência & Percentagem & $\begin{array}{c}\text { Percentagem } \\
\text { Cumulativa }\end{array}$ \\
$\mathbf{1}$ 을 Ciclo & 37 & 26,1 & 27,6 \\
$\mathbf{2}$ Ciclo & 52 & 36,6 & 66,4 \\
$\mathbf{3}^{\circ}$ Ciclo & 28 & 19,7 & 87,3 \\
Secundário & 17 & 12,0 & 100,0 \\
Total & 134 & 94,4 & \\
\hline
\end{tabular}




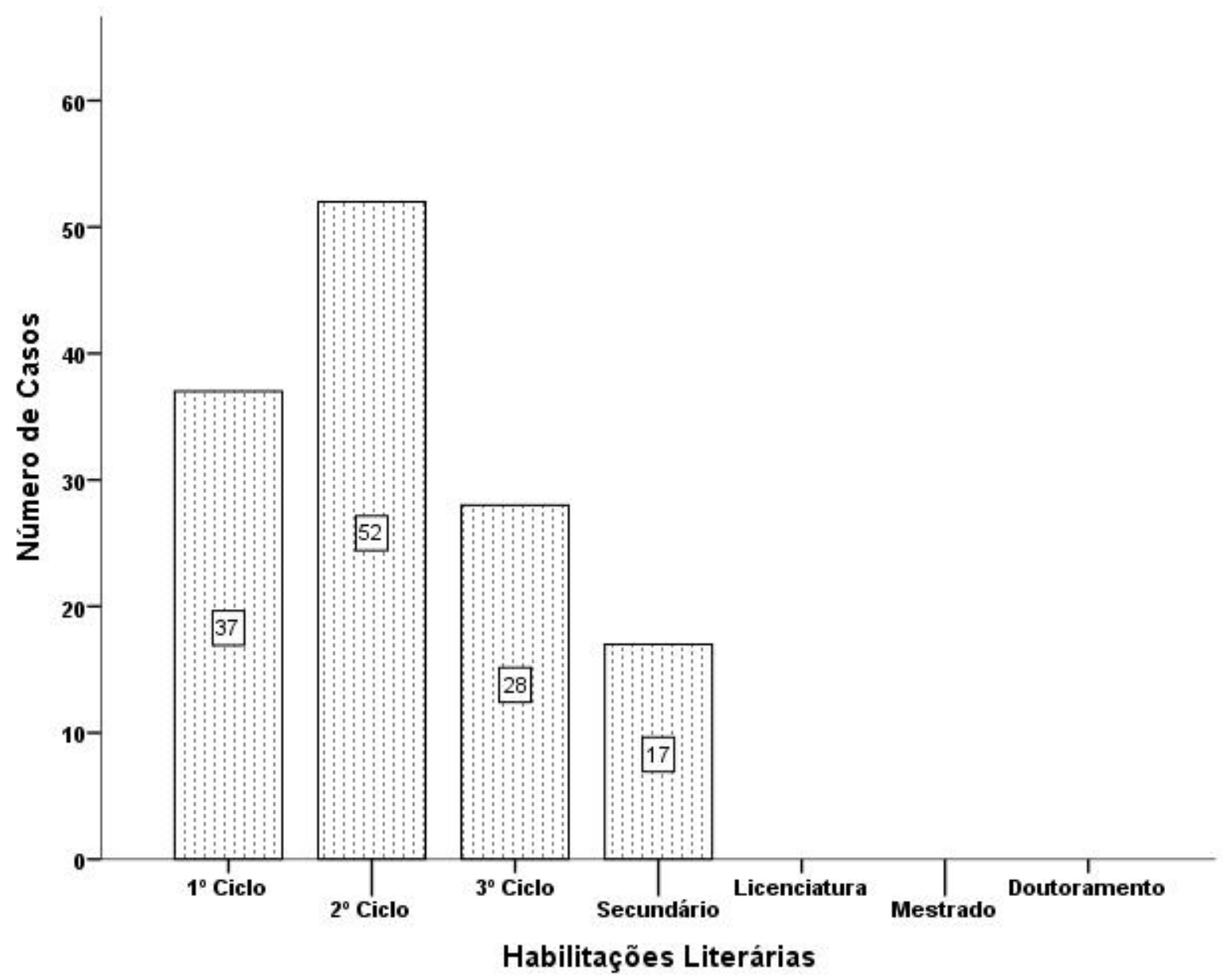

Figura 15 - Número de Trabalhadores segundo as habilitações literárias

\subsection{Resultados dos Questionários}

Antes da aplicação do questionário final, realizou-se um teste-reteste. Para a avaliação da consistência interna, usou-se o coeficiente Alpha de Cronbach (Doane DP., et al., 2008; Spector, PE., 1982). As variáveis apresentaram uma consistência interna de 0,93 no teste e no reteste.

Foi calculado o coeficiente de correlação para 18 questionários. Nota-se uma melhoria dos valores do alfa e dos coeficientes na maioria dos itens após as seguintes alterações: 
Após a análise do feedback por parte dos trabalhadores relativos a estes dois ensaios foi necessário introduzir as seguintes modificações:

- Acrescentar os anos escolares a que correspondem cada ciclo de estudos [exemplo: $1^{\circ}$ ciclo (4⿳亠丷厂 classe); $2^{\circ}$ ciclo (6ํano); $3^{\circ}$ ( $9^{\circ}$ ano); e secundário $\left(12^{\circ}\right.$ ano $\left.)\right]$.

- A questão no 2 estava formulada "Concorda com as seguintes afirmações relativas ao conhecimento dos produtos químicos utilizados?" e alterou-se para "Concorda com as seguintes afirmações relativas ao meu conhecimento dos produtos químicos utilizados?".

- $\mathrm{Na}$ afirmação I) da questão no 5 foi substituída a palavra "danificada" por "estragada", ou seja, em vez de "Quando a minha máscara está danificada espero que termine o trabalho para a substituir", ficando "Quando a minha máscara está estragada espero que termine o trabalho para a substituir".

- Na questão № 10, afirmação o), a frase "Já tive vertigens no meu posto de trabalho" foi substituída por "Já tive vertigens/tonturas no meu posto de trabalho". Foi introduzida a palavra "tonturas" por forma a permitir uma melhor perceção do significado de vertigens. Esta introdução também se efetuou na afirmação p) que ficou com a redação, "A exposição às tintas/velaturas, vernizes e tapa poros causa-me vertigens/tonturas". Na afirmação r) "A minha perceção aos cheiros diminuiu desde que fiquei exposto às tintas/velaturas, vernizes e tapa poros", acrescentou-se a palavra sensibilidade, ficando, "A minha perceção/sensibilidade aos cheiros diminuiu desde que fiquei exposto às tintas/velaturas, vernizes e tapa poros". 
- A afirmação c) da questão oㅜ 10, "Nem sempre os recipientes vazios das tintas/velaturas, vernizes e tapa poros são retirados imediatamente dos postos de trabalho" foi alterada para "Às vezes os recipientes vazios das tintas/velaturas, vernizes e tapa poros não são retirados imediatamente dos postos de trabalho".

- Relativamente à questão № 12 , a afirmação a) "Ignorar as regras de segurança" foi substituída por "Não cumprir as regras de segurança".

O cálculo do coeficiente de Alpha de Cronbach para o questionário foi de 0,97 , revelando que as alterações introduzidas foram benéficas.

\subsubsection{Perceção ao Risco}

\subsubsection{Conhecimento do Risco dos Produtos Químicos}

Neste grupo pretende-se saber o grau de conhecimento do risco de diferentes produtos e substâncias químicas.

Os trabalhadores classificam em média o risco das tintas/velaturas, vernizes, tapa poros e diluentes entre "pouco risco" e "médio risco". Em relação ao tolueno os trabalhadores ou não têm opinião ou consideram-no de nenhum risco (Figura 16). 


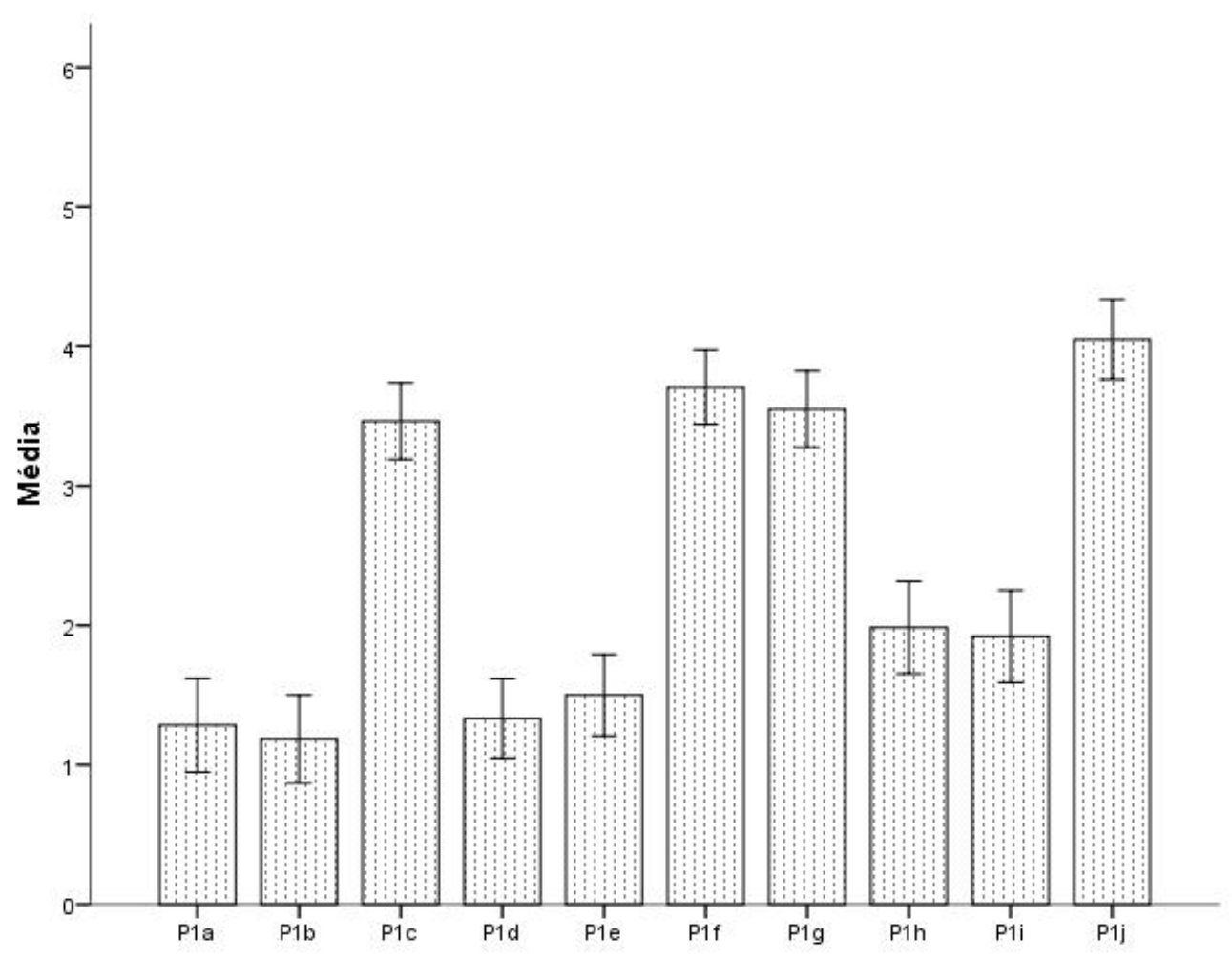

Figura 16 - Média das respostas (0 - não aplicável; 1 - sem opinião; 2 - nenhum risco; 3 pouco risco; 4 - médio risco; 5 - muito risco; 6 - elevadíssimo risco) sobre a classificação do risco associado: ao ácido clorídrico (1a); soda cáustica (1b); tintas/velaturas da madeira (1c); lubrificantes (1d); detergentes (1e); vernizes (1f); tapa poros (1g); xileno (1h); tolueno (1i) e diluente (1j).

No conhecimento do risco associado às tintas/velaturas da madeira (grupo 1 alínea c) do questionário), 32,9\% dos trabalhadores classifica-o de "médio risco", 27,1\% de "muito risco", 15,7 de "pouco risco", 9,3 \% "não aplicável", 9,3 \% "sem opinião", 2,9 \% de "nenhum risco" e 2,9 \% de "elevadíssimo risco". 0 teste Mann Whitney, revelou que não existem diferenças significativas entre as empresas ( $p=0,182 ; \alpha=0,05)$, entre as habilitações literárias $(p=0,178 ; \alpha=0,05)$ e entre as faixas etárias $(p=0,987 ; \alpha=0,05)$. No entanto, revelou que existem diferenças significativas entre os diferentes tipos de produção $(p \leq 0,05)$ e entre os sexos $(p \leq 0,05)$ (Anexo 7.2 -Tabela 11). 
Em relação ao verniz (grupo 1 alínea f) do questionário), 36,4 \% considera-o de "médio risco", 30,7 \% de "muito risco", 12,1\% de "pouco risco", 9,3 \% "não aplicável", 5,0 \% "sem opinião", 4,3 \% de "elevadíssimo risco" e 2,1 $\%$ de "nenhum risco". O teste Mann Whitney, revelou que não existem diferenças significativas entre as empresas $(p=0,305 ; \alpha=0,05)$, entre os sexos $(p=0,278$; $\alpha=0,05)$, entre as habilitações literárias $(p=0,223 ; \alpha=0,05)$ e entre as faixas etárias $(p=0,251 ; \alpha=0,05)$. No entanto, revelou que existem diferenças significativas entre os diferentes tipos de produção $(p \leq 0,05)$ (Anexo $7.2-$ Tabela 12).

No tapa poros (grupo 1 alínea g) do questionário), 35,2 \% dos trabalhadores classificam de "médio risco", $24,6 \%$ de "muito risco", $14,1 \%$ de "pouco risco", 9,2 \% "não aplicável", 7,7 \% "sem opinião", 5,6 \% de "elevadíssimo risco" e $3,5 \%$ de "nenhum risco". O teste Mann Whitney, revelou que não existem diferenças significativas entre as empresas $(p=0,271 ; \alpha=0,05)$, entre os diferentes tipos de produção ( $p=0,156 ; \alpha=0,05)$, entre as habilitações literárias $(p=0,394 ; \alpha=0,05)$ e entre as faixas etárias $(p=0,077 ; \alpha=0,05)$. No entanto, revelou que existem diferenças significativas entre os sexos $(p \leq 0,05)$ (Anexo 7.2 - Tabela 13).

Quanto ao xileno (grupo 1 alínea h) do questionário), 44,2 \% dos trabalhadores indicam "sem opinião", 21,7 \% "não aplicável", 12,3 \% "muito risco", 8,0 \% "médio risco", 7,2 \% "pouco risco" e 6,5 \% "elevadíssimo risco". O teste Mann Whitney, revelou que não existem diferenças significativas entre as empresas ( $p=0,271 ; \alpha=0,05)$, entre as habilitações literárias $(p=0,283 ; \alpha=0,05)$, entre os diferentes tipos de produção $(p=0,030 ; \alpha=0,05)$ e entre as faixas etárias $(p=0,525 ; \alpha=0,05)$. No entanto, revelou que existem diferenças significativas entre os sexos $(p \leq 0,05)$ (Anexo $7.2-$ Tabela 14).

Em relação ao tolueno (grupo 1 alínea i) do questionário), 48,2 \% dos trabalhadores indicam "sem opinião", 20,9 \% "não aplicável", 9,4 \% "muito risco", 8,6 \% "elevadíssimo risco", 6,5\% "pouco risco" e 6,5\% "médio risco". O teste Mann Whitney, revelou que não existem diferenças significativas entre as empresas ( $p=0,271 ; \alpha=0,05)$, entre os diferentes tipos de produção ( $p=0,615$; $\alpha=0,05)$, entre os sexos $(p=0,074 ; \alpha=0,05)$, entre as habilitações literárias 
$(p=0,097 ; \alpha=0,05)$ e entre as faixas etárias $(p=0,246 ; \alpha=0,05)$. No entanto, revelou que existem diferenças significativas entre as empresas $(p \leq 0,05)$ (Anexo 7.2 -Tabela 15).

No conhecimento do risco associado ao diluente (grupo 1 alínea j) do questionário), 30,0 \% dos inquiridos classificam de "muito risco", 27,1 \% "médio risco", 17,9 \% "elevadíssimo risco", 10,7 \% "pouco risco", 7,9 \% "não aplicável", $5,7 \%$ "sem opinião" e 0,7 \% de "nenhum risco". O teste Mann Whitney, revelou que não existem diferenças significativas, entre os sexos $(p=0,614 ; \alpha=0,05)$, entre as habilitações literárias $(p=0,397 ; \alpha=0,05)$ e entre as faixas etárias $(p=0,300 ; \alpha=0,05)$. No entanto, revelou que existem diferenças significativas entre as empresas $(p \leq 0,05)$ e entre os diferentes tipos de produção $(p \leq 0,05)$ (Anexo 7.2 - Tabela 16).

\subsubsection{Conhecimento dos Produtos Químicos Utilizados}

Com estas questões pretende-se aferir o grau de conhecimento dos inquiridos sobre os produtos químicos que utilizam.

A média das opiniões sobre o facto de saberem distinguir as tintas/velaturas, vernizes e tapa poros centra-se entre o "nem concordo, nem discordo" e o "concordo". Referem em média, entre o "discordo" e o "nem concordo, nem discordo" sobre se já leram as fichas de dados de segurança dos produtos químicos que utilizam, a mesma opinião é expressa pela maioria dos trabalhadores no que se refere ao conhecimento sobre se as tintas/velaturas, vernizes e tapa poros que utilizam são da base solvente. Quanto à afirmação se o xileno e o tolueno são substâncias químicas que compõem as tintas/velaturas, vernizes e tapa poros, a média dos inquiridos respondeu entre o "discordo totalmente" e o "discordo", têm a mesma opinião acerca da afirmação se as tintas/velaturas, vernizes e tapa poros que utilizo de base solvente têm os mesmos riscos se forem de base aquosa (Figura 17). 


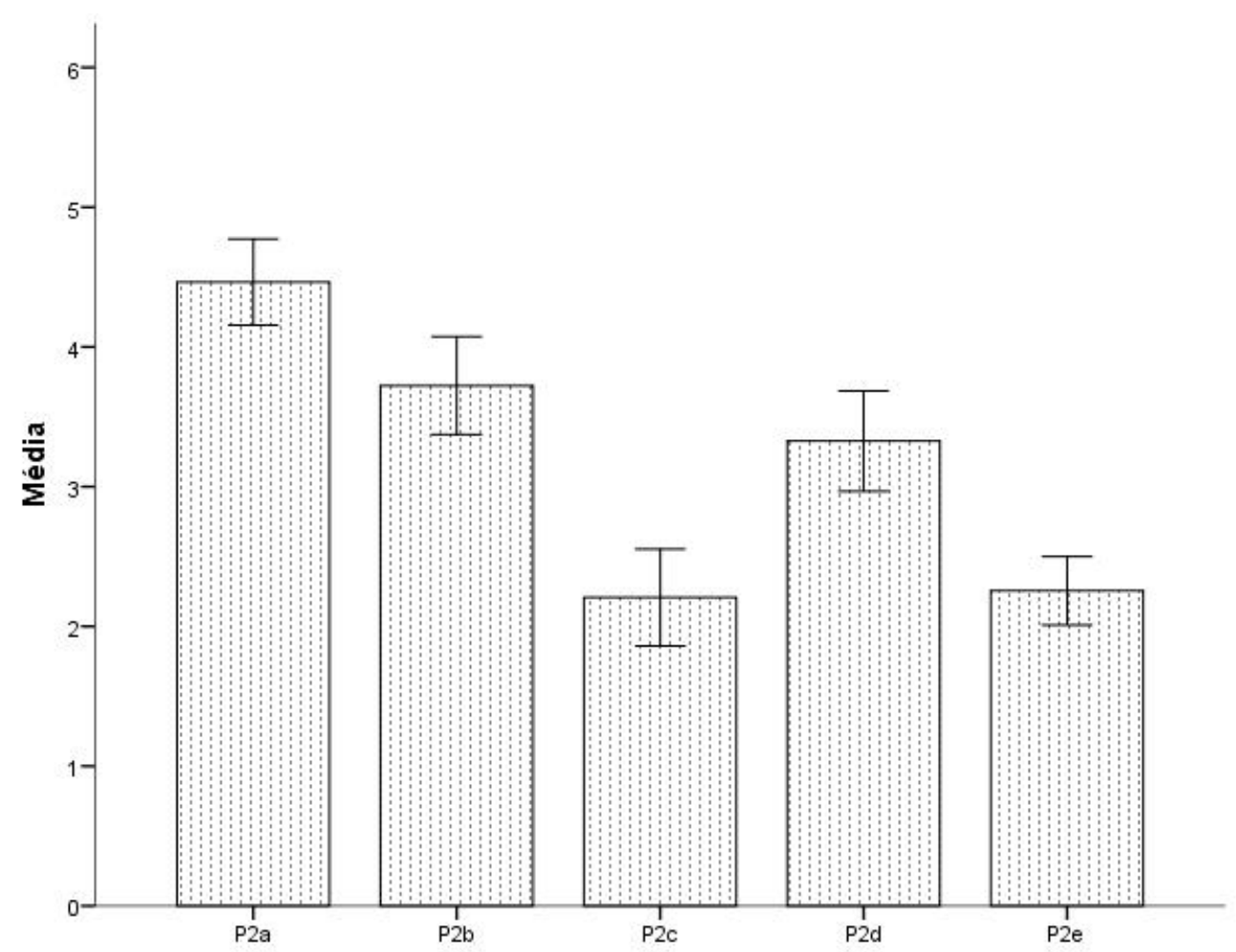

Figura 17 - Média das respostas (0 - não aplicável; 1 - sem opinião; 2 - discordo totalmente; 3 - discordo; 4 - nem concordo, nem discordo; 5 - concordo; 6 - concordo totalmente) sobre o conhecimento dos produtos químicos utilizados: sei distinguir as tintas/velaturas, vernizes e tapa poros (2a); já li as fichas de dados de segurança dos produtos químicos que utilizo (2b); o xileno e o tolueno são substâncias químicas que compõem as tintas/velaturas, vernizes e tapa poros

(2c); as tintas/velaturas, vernizes e tapa poros que utilizo são da base solvente (2d); as tintas/velaturas, vernizes e tapa poros que utilizo de base solvente têm os mesmos riscos se forem de base aquosa (2e).

No facto dos trabalhadores saberem distinguir as tintas/velaturas, vernizes e tapa poros (grupo 2 alínea a) do questionário), 45,1 \% "concordam", 30,3 \% "concordam totalmente", 8,5 \% "não têm opinião", 7 \% considera "não aplicável", $5,6 \%$ "nem concorda, nem discorda", 2,1 \% "discorda totalmente" e 1,4\% "discorda". O teste Mann Whitney, revelou que não existem diferenças significativas entre as faixas etárias $(p=0,599 ; \alpha=0,05)$ e entre as habilitações literárias $(p=0,227 ; \alpha=0,05)$. Contudo, revelou que existem diferenças significativas entre os diferentes tipos de produção $(p \leq 0,05)$, entre os sexos $(p \leq$ $0,05)$ e entre as empresas $(p \leq 0,05)$ (Anexo 7.3-Tabela 17). 
Dos inquiridos 43,3\% "concordam" já leram as fichas de dados de segurança dos produtos químicos que utilizam (grupo 2 alínea b) do questionário), 14,9\% "concordam totalmente", 14,9 \% consideram "não aplicável", 9,2 \% "não têm opinião", 8,5 \% "nem concorda, nem discorda", 5 \% "discorda" e 4,3 \% "discorda totalmente". O teste Mann Whitney, revelou que não existem diferenças significativas entre as faixas etárias $(p=0,987 ; \alpha=0,05)$ e entre as habilitações literárias $(p=0,328 ; \alpha=0,05)$. Revelou, no entanto, que existem diferenças significativas entre os diferentes tipos de produção $(p \leq 0,05)$, entre os sexos $(p \leq 0,05)$ e entre as empresas $(p \leq 0,05)$ (Anexo 7.3 - Tabela 18).

Quanto à afirmação se o xileno e o tolueno são substâncias químicas que compõem as tintas/velaturas, vernizes e tapa poros (grupo 2 alínea c) do questionário), 47,1 \% dos trabalhadores indicam "sem opinião", 16,4\% consideram "não aplicável", 14,3 \% "concorda", $10 \%$ "nem concorda, nem discorda", 9,3\% "concorda totalmente", 2,1\% "discorda totalmente" e 0,7 \% discorda. O teste Mann Whitney, revelou que não existem diferenças significativas entre, entre os diferentes tipos de produção ( $p=0,086 ; \alpha=0,05)$. Revelou, no entanto, que existem diferenças significativas entre os sexos ( $p \leq$ $0,05)$, entre as empresas $(p \leq 0,05)$, entre as faixas etárias $(p \leq 0,05)$ e entre as habilitações literárias $(p \leq 0,05)$ (Anexo 7.3 -Tabela 19).

Se os trabalhadores sabem se as tintas/velaturas, vernizes e tapa poros que utilizam são da base solvente (grupo 2 alínea d) do questionário), 41,8\% "concorda", 23,4 \% "sem opinião", 12,8 \% responde "não aplicável", 9,9 \% "concorda totalmente", 5,7 \% "nem concorda, nem discorda", 5 \% "discorda" e $1,4 \%$ "discorda totalmente". O teste Mann Whitney, revelou que não existem diferenças significativas entre as habilitações literárias $(p=0,263 ; \alpha=0,05)$. Existem diferenças significativas entre os diferentes tipos de produção $(p \leq 0,05)$, entre os sexos $(p \leq 0,05)$, entre as empresas $(p \leq 0,05)$ e entre as faixas etárias $(p \leq 0,05)$ (Anexo $7.3-$ Tabela 20).

Dos trabalhadores, 29,1\% "discorda" que as tintas/velaturas, vernizes e tapa poros que utilizam de base solvente têm os mesmos riscos se forem de base aquosa (grupo 2 alínea e) do questionário), 22,7 \% "sem opinião", 17,7 \% "discorda totalmente", 12,8 \% refere "não aplicável", 9,2\% "nem concorda, nem 
discorda", 7,8 \% "concorda" e 0,7 \% "concorda totalmente". O teste Mann Whitney, revelou que não existem diferenças significativas entre as faixas etárias $(p=0,320 ; \alpha=0,05)$. Existem diferenças significativas entre os diferentes tipos de produção $(p \leq 0,05)$, entre os sexos $(p \leq 0,05)$, entre as empresas $(p \leq 0,05)$ e entre as habilitações literárias $(p \leq 0,05)$ (Anexo 7.3 - Tabela 21).

\subsubsection{Comportamentos na Manipulação de Produtos Químicos}

Com as respostas a estas afirmações pretende-se saber quais são os comportamentos adotados pelos trabalhadores durante a utilização das tintas/velaturas, vernizes e tapa poros.

Os trabalhadores em média, não têm opinião ou consideram a exposição a lubrificantes de "nenhum risco", no entanto, classificam entre o "pouco risco" e o "médio risco" a exposição às tintas/velaturas, tapa poros, vernizes, diluentes, diluição de tintas/velaturas, tapa poros e vernizes, aplicação de tintas/velaturas, tapa poros e vernizes fora das cabines, proximidade da estufa de secagem e manusear tintas/velaturas, tapa poros e vernizes sem luvas. Em relação à aplicação de tintas/velaturas, tapa poros e vernizes com as cabines desligadas, manusear tintas/velaturas, tapa poros e vernizes sem máscara e não usar Equipamentos de Proteção Individual (EPI's) na aplicação das tintas/velaturas, tapa poros e vernizes, em média os trabalhadores consideram estes comportamentos entre o "médio risco" e o "muito risco" (Figura 18). 


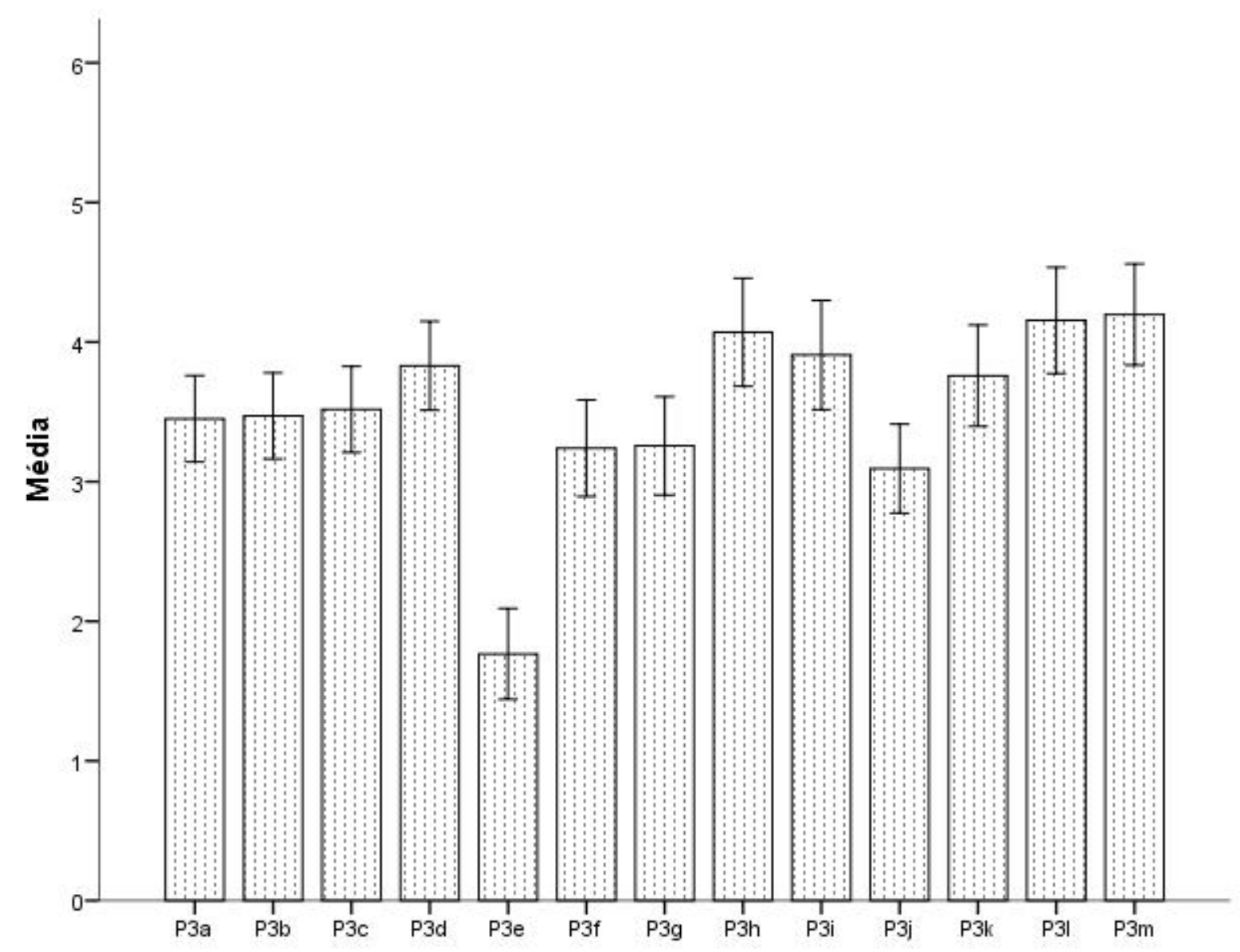

Figura 18 - Média das respostas (0 - não aplicável; 1 - sem opinião; 2 - nenhum risco; 3 pouco risco; 4 - médio risco; 5 - muito risco; 6 - elevadíssimo risco) sobre o comportamento na manipulação dos produtos químicos: exposição às tintas/velaturas (3a); exposição a tapa poros (3b); exposição aos vernizes (3c); exposição aos diluentes (3d); exposição a lubrificantes (3e); aplicação das tintas/velaturas, tapa poros e vernizes (3f); diluição das tintas/velaturas, tapa poros e vernizes ( $3 \mathrm{~g}$ ); aplicação das tintas/velaturas, tapa poros e vernizes com as cabines desligadas (3h); aplicação das tintas/velaturas, tapa poros e vernizes fora das cabines (3i); proximidade da

estufa de secagem (3j); manusear tintas/velaturas, tapa poros e vernizes sem luvas (3k); manusear tintas/velaturas, tapa poros e vernizes sem máscara (3l); não usar Equipamentos de

Proteção Individual (EPI's) na aplicação das tintas/velaturas, tapa poros e vernizes (3m)

Os trabalhadores, $28,9 \%$ classificam de "médio risco" e a mesma percentagem de "muito risco" a exposição às tintas/velaturas (grupo 3 alínea a) do questionário), 15,5\% consideram "não aplicável", 12,0 \% "pouco risco", 6,3\% de "elevadíssimo risco", 5,6 \% "não têm opinião" e 2,8 \% de "nenhum risco". O teste Mann Whitney, revelou que não existem diferenças significativas entre as empresas ( $p=0,099 ; \alpha=0,05)$, entre as habilitações literárias ( $p=0,282 ; \alpha=0,05)$, 
entre as faixas etárias $(p=0,085 ; \alpha=0,05)$ e entre os sexos $(p=0,098 ; \alpha=0,05)$. No entanto, revelou que existem diferenças significativas entre os diferentes tipos de produção ( $p \leq 0,05)$ (Anexo 7.4 -Tabela 22).

Relativamente à exposição ao tapa poros (grupo 3 alínea b) do questionário), 30,3\% classificam de "médio risco", 26,1\% de "muito risco" a exposição às tintas/velaturas (grupo 3 alínea a) do questionário), 15,5\% consideram "não aplicável", 13,4 \% "pouco risco", 7,7 \% de "elevadíssimo risco", 4,9 \% "não têm opinião" e 2,1 \% de "nenhum risco". O teste Mann Whitney, revelou que não existem diferenças significativas entre as habilitações literárias $(p=0,209 ; \alpha=0,05)$, entre as faixas etárias $(p=0,106 ; \alpha=0,05)$ e entre os sexos $(p=0,100 ; \alpha=0,05)$. No entanto, revelou que existem diferenças significativas entre os diferentes tipos de produção $(p \leq 0,05)$ e entre as empresas $(p \leq 0,05)$ (Anexo 7.4 - Tabela 23).

Aos vernizes (grupo 3 alínea c) do questionário), 31,2 \% dos trabalhadores indicam a exposição como "muito risco", 29,8\% de "médio risco", 15,6 \% "não aplicável", 12,1 \% "pouco risco", 5,7 \% de "elevadíssimo risco", 5,0 \% "sem opinião" e 0,7 \% de "nenhum risco". O teste Mann Whitney, revelou que não existem diferenças significativas entre as habilitações literárias $(p=0,521$; $\alpha=0,05$. No entanto, revelou que existem diferenças significativas entre os diferentes tipos de produção ( $p \leq 0,05)$, entre os sexos $(p \leq 0,05)$, entre as faixas etárias $(p \leq 0,05)$ e entre as empresas $(p \leq 0,05)$ (Anexo $7.4-$ Tabela 24).

Da exposição aos diluentes (grupo 3 alínea d) do questionário), 39,0 \% dos trabalhadores indicam com "muito risco", 21,3\% de "médio risco", 14,2 \% "não aplicável", 12,1 \% de "elevadíssimo risco", 7,8 \% "pouco risco", 4,3 \% "sem opinião" e 1,4 \% de "nenhum risco". O teste Mann Whitney, revelou que não existem diferenças significativas, entre os sexos $(p=0,258 ; \alpha=0,05)$, entre as faixas etárias $(p=0,256 ; \alpha=0,05)$. No entanto, revelou que existem diferenças significativas entre os diferentes tipos de produção $(p \leq 0,05)$, entre as empresas $(p \leq 0,05)$, entre as habilitações literárias $(p \leq 0,05)$ (Anexo $7.4-$ Tabela 25).

Em relação à exposição a lubrificantes (grupo 3 alínea e) do questionário), 40,9 \% dos inquiridos considera "não aplicável", 19,7\% de "médio risco", 19,7 \% 
"sem opinião", 7,3 \% "pouco risco", 6,6 \% com "muito risco", 2,9 \% de "nenhum risco" e 2,9 \% de "elevadíssimo risco". O teste Mann Whitney, revelou que não existem diferenças significativas, entre as empresas $(p=0,058 ; \alpha=0,05)$, entre os diferentes tipos de produção $(p=0,251 ; \alpha=0,05)$, entre os sexos $(p=0,376$; $\alpha=0,05)$, entre as habilitações literárias $(p=0,370 ; \alpha=0,05)$ e entre as faixas etárias $(p=0,098 ; \alpha=0,05)$ (Anexo 7.4 - Tabela 26).

$\mathrm{Na}$ aplicação de tintas/velaturas, tapa poros e vernizes (grupo 3 alínea f) do questionário), 28,9 \% dos trabalhadores referiram que existia "muito risco", $25,4 \%$ de "médio risco", 21,8\% considera "não aplicável", 7,7 \% de "elevadíssimo risco", 7,0 \% "sem opinião", 6,3 \% "pouco risco" e 2,8 \% de "nenhum risco". O teste Mann Whitney, revelou que não existem diferenças significativas, entre as habilitações literárias $(p=0,128 ; \alpha=0,05)$. No entanto, revelou que existem diferenças significativas entre os diferentes tipos de produção $(p \leq 0,05)$, entre as empresas $(p \leq 0,05)$, entre os sexos $(p \leq 0,05)$ e entre as faixas etárias $(p \leq 0,05)$ (Anexo $7.4-$ Tabela 27).

Quanto à diluição das tintas/velaturas, tapa poros e vernizes (grupo 3 alínea g) do questionário), 27,1 \% dos trabalhadores disseram que exista "muito risco", 23,6 \% de "médio risco", 20,7 \% considera "não aplicável”, 10,0 \% de "elevadíssimo risco", 9,3 \% "sem opinião", 7,9 \% "pouco risco" e 1,4 \% de "nenhum risco". O teste Mann Whitney, revelou que não existem diferenças significativas, entre as habilitações literárias $(p=0,458 ; \alpha=0,05)$ e entre as faixas etárias $(p=0,065 ; \alpha=0,05)$. No entanto, revelou que existem diferenças significativas entre os diferentes tipos de produção $(p \leq 0,05)$, entre as empresas $(p \leq 0,05)$ e entre os sexos $(p \leq 0,05)$ (Anexo 7.4-Tabela 28).

Sobre o facto de aplicarem as tintas/velaturas, tapa poros e vernizes com as cabines desligadas (grupo 3 alínea h) do questionário), 37,3\% considera esta atitude de "elevadíssimo risco", 29,6 \% de "muito risco", 19,0 \% considera "não aplicável", 5,6 \% "sem opinião", 4,9 \% de "médio risco", 2,8 \% "pouco risco" e 0,7 $\%$ de "nenhum risco". O teste Mann Whitney, revelou que não existem diferenças significativas, entre as habilitações literárias $(p=0,323 ; \alpha=0,05)$ e entre as faixas etárias $(p=0,622 ; \alpha=0,05)$. No entanto, revelou que existem diferenças 
significativas entre os diferentes tipos de produção $(p \leq 0,05)$, entre as empresas $(p \leq 0,05)$ e entre os sexos ( $p \leq 0,05)$ (Anexo 7.4-Tabela 29).

$\mathrm{Na}$ aplicação de tintas/velaturas, tapa poros e vernizes fora das cabines (grupo 3 alínea i) do questionário), 32,1 \% considera esta atitude de "elevadíssimo risco", 31,4 \% de "muito risco", 19,3 \% considera "não aplicável", 7,9 \% "sem opinião", 6,4 \% de "médio risco", 1,4 \% "pouco risco" e 1,4 \% de "nenhum risco". O teste Mann Whitney, revelou que não existem diferenças significativas, entre as habilitações literárias $(p=0,187 ; \alpha=0,05)$ e entre as faixas etárias $(p=0,561 ; \alpha=0,05)$. No entanto, revelou que existem diferenças significativas entre os diferentes tipos de produção $(p \leq 0,05)$, entre as empresas $(p \leq 0,05)$ e entre os sexos $(p=0,038 ; \alpha=0,05)$ (Anexo $7.4-$ Tabela 30$)$.

Em relação à proximidade da estufa de secagem (grupo 3 alínea j) do questionário), 29,5 \% refere que existe "médio risco", 19,4 \% "muito risco", 17,3 \% considera "não aplicável", 14,4 \% "pouco risco", 10,8 \% "sem opinião", 5,8 \% "elevadíssimo risco", e 2,9 \% de "nenhum risco". O teste Mann Whitney, revelou que não existem diferenças significativas, entre os sexos $(p=0,092 ; \alpha=0,05)$, entre as habilitações literárias $(p=0,123 ; \alpha=0,05)$ e entre as faixas etárias $(p=0,289 ; \alpha=0,05)$. No entanto, revelou que existem diferenças significativas entre os diferentes tipos de produção $(p \leq 0,05)$ e entre as empresas $(p \leq 0,05)$ e (Anexo 7.4 - Tabela 31).

Manusear as tintas/velaturas, tapa poros e vernizes sem luvas (grupo 3 alínea k) do questionário), 31,2 \% dos inquiridos classifica como "muito risco", 21,3 \% "elevadíssimo risco", 19,9 \% considera "não aplicável", 17,7 \% com "médio risco", 5,7 \% "pouco risco" e 4,3 \% "sem opinião". O teste Mann Whitney, revelou que não existem diferenças significativas, entre as habilitações literárias $(p=0,120 ; \alpha=0,05)$ e entre as faixas etárias $(p=0,170 ; \alpha=0,05)$. No entanto, revelou que existem diferenças significativas entre os diferentes tipos de produção $(p \leq 0,05)$, entre os sexos $(p \leq 0,05)$ e entre as empresas $(p \leq 0,05)$ e (Anexo 7.4 - Tabela 32).

Manusear as tintas/velaturas, tapa poros e vernizes sem máscara (grupo 3 alínea I) do questionário), 40,1 \% dos trabalhadores considera esta atitude de 
"elevadíssimo risco", 25,4 \% de "muito risco", 19,0 \% considera "não aplicável", 8,5 \% "médio risco", 3,5 \% "pouco risco" e 3,5 \% "sem opinião". O teste Mann Whitney, revelou que não existem diferenças significativas, entre as habilitações literárias $(p=0,412 ; \alpha=0,05)$ e entre as faixas etárias $(p=0,092 ; \alpha=0,05)$. No entanto, revelou que existem diferenças significativas entre os diferentes tipos de produção $(p \leq 0,05)$, entre os sexos $(p \leq 0,05)$ e entre as empresas $(p \leq 0,05)$ e (Anexo 7.4 - Tabela 33).

Quanto aos trabalhadores não usarem Equipamentos de Proteção Individual (EPI's) na aplicação das tintas/velaturas, tapa poros e vernizes (grupo 3 alínea $\mathrm{m}$ ) do questionário), 35,9\% dos trabalhadores considera esta atitude de "elevadíssimo risco", 31,7 \% de "muito risco", 14,8 \% considera "não aplicável", 7,0 \% "médio risco", 7,0 \% "sem opinião" e 3,5 \% "pouco risco". O teste Mann Whitney, revelou que não existem diferenças significativas, entre as faixas etárias $(p=0,185 ; \alpha=0,05)$. No entanto, revelou que existem diferenças significativas entre os diferentes tipos de produção $(p \leq 0,05)$, entre os sexos ( $p \leq$ $0,05)$, entre as habilitações literárias $(p \leq 0,05)$ e entre as empresas $(p \leq 0,05)$ e (Anexo 7.4 - Tabela 34). 


\subsubsection{Perceção do Risco da Exposição a tintas/velaturas, vernizes e tapa poros}

Nesta seção pretende-se conhecer qual é a real perceção por parte dos trabalhadores inquiridos sobre o risco da exposição a tintas/velaturas, vernizes e tapa poros.

Em média a resposta sobre se a exposição aos gases/vapores das tintas/velaturas, vernizes e tapa poros pode ser perigosa situa-se entre o "nem concordo, nem discordo" e o "concordo". O mesmo acontece com as respostas às questões se as exposições aos gases/vapores das tintas/velaturas e do tapa poros são perigosas e se a exposição a estes produtos pode provocar doenças. Em relação à média das respostas sobre a exposição aos gases/vapores dos vernizes ser perigosa, esta situa-se entre o "concordo" e o "concordo totalmente". Os trabalhadores já classificam entre o "discordo" e o "nem concordo, nem discordo" a média das respostas sobre se não existe risco se a exposição for por pouco tempo e se a exposição a estes produtos não provoca danos para a saúde (Figura 19). 


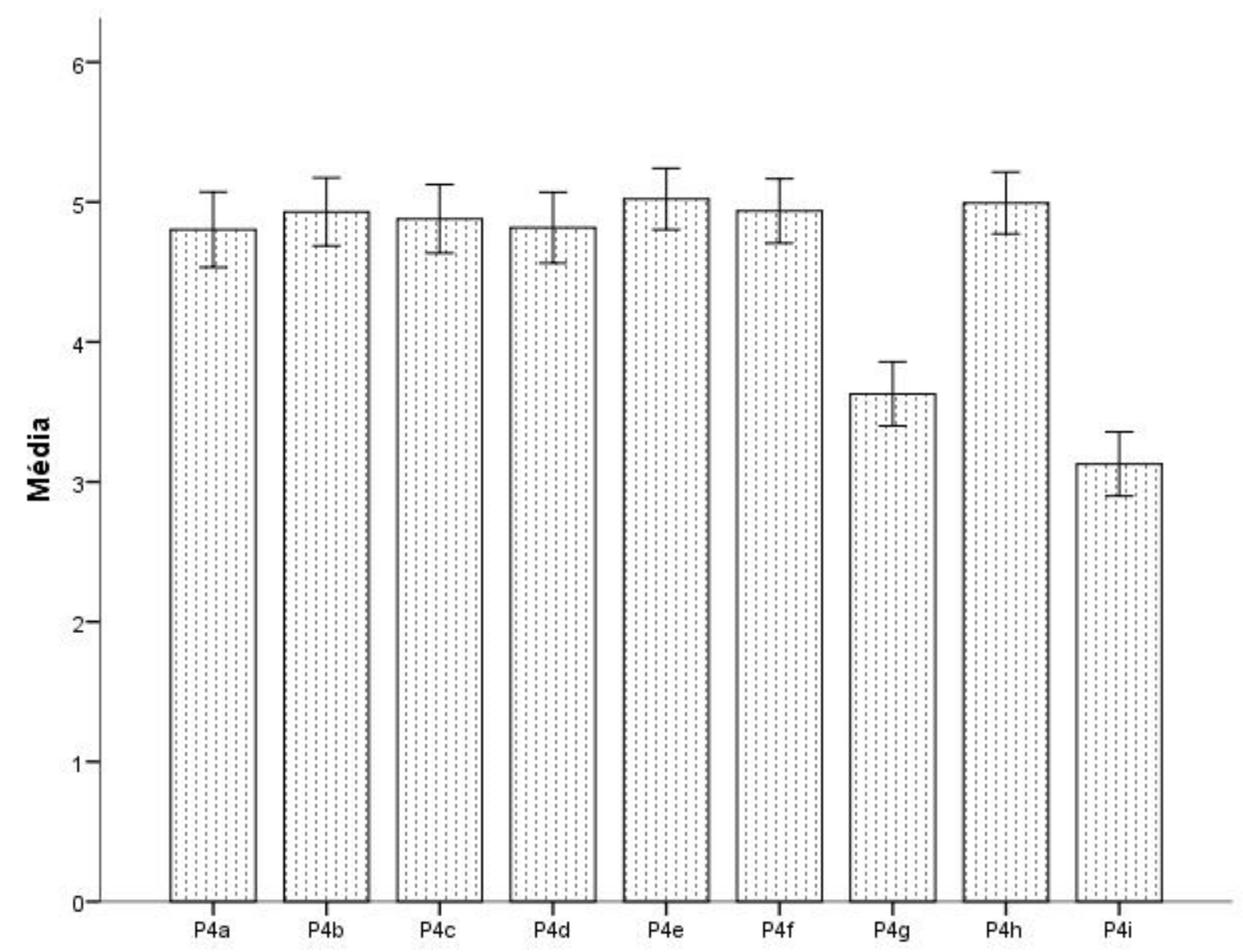

Figura 19 - Média das respostas ( 0 - não aplicável; 1 - sem opinião; 2 - discordo totalmente; 3

- discordo; 4 - nem concordo, nem discordo; 5 - concordo; 6 - concordo totalmente) sobre

Perceção do Risco da Exposição a tintas/velaturas, vernizes e tapa poros: a exposição aos gases/vapores das tintas/velaturas pode ser perigosa (4a); a exposição aos gases/vapores dos vernizes pode ser perigosa (4b); a exposição aos gases/vapores a tapa poros pode ser perigosa

(4c); a exposição aos gases/vapores das tintas/velaturas é perigosa (4d); a exposição aos gases/vapores dos vernizes é perigosa (4e); a exposição aos gases/vapores do tapa poros é perigosa (4f); não existe risco se a exposição for por pouco tempo (4g); a exposição a estes produtos pode provocar doenças (4h); a exposição a estes produtos não provoca danos para a saúde (4i)

Sobre a exposição aos gases/vapores das tintas/velaturas poder ser perigosa (grupo 4 alínea a) do questionário), 45,8 \% dos trabalhadores refere que "concorda", 37,3 \% "concorda totalmente", 6,3 \% "sem opinião", 4,2 \% considera "não aplicável", 1,4 \% "discorda" e a mesma percentagem "discorda totalmente". O teste Mann Whitney, revelou que não existem diferenças significativas, entre os diferentes tipos de produção $(p=0,213 ; \alpha=0,05)$, entre as 
habilitações literárias $(p=0,651 ; \alpha=0,05)$ e entre as faixas etárias $(p=0,071$; $\alpha=0,05)$. No entanto, revelou que existem diferenças significativas entre os sexos $(p \leq 0,05)$ e entre as empresas $(p \leq 0,05)$ (Anexo 7.5 - Tabela 35).

Em relação às respostas à questão se a exposição aos gases/vapores dos vernizes pode ser perigosa (grupo 4 alínea b) do questionário), 51,4 \% indica que "concorda", 36,6 \% "concorda totalmente", 5,6 \% indica "sem opinião", 2,8 \% "não aplicável", 1,4 \% "nem concorda, nem discorda", 1,4\% "discorda totalmente" e 0,7 \% "discorda". O teste Mann Whitney, revelou que não existem diferenças significativas, entre os diferentes tipos de produção $(p=0,564 ; \alpha=0,05)$ e entre as habilitações literárias $(p=0,412 ; \alpha=0,05)$. No entanto, revelou que existem diferenças significativas entre os sexos $(p \leq 0,05)$, entre as faixas etárias $(p \leq 0,05)$ e entre as empresas $(p \leq 0,05)$ (Anexo 7.5 - Tabela 36).

Nas respostas à questão se a exposição aos gases/vapores do tapa poros poder ser perigosa (grupo 4 alínea c) do questionário), 52,5\% indica que "concorda", 34,0 \% "concorda totalmente", 3,5 \% indica "sem opinião", 3,5 \% "não aplicável", 3,5 \% "discorda totalmente", 2,1 \% "nem concorda, nem discorda" e 0,7 \% "discorda". O teste Mann Whitney, revelou que não existem diferenças significativas, entre os diferentes tipos de produção $(p=0,629 ; \alpha=0,05)$ e entre as habilitações literárias $(p=0,232 ; \alpha=0,05)$. No entanto, revelou que existem diferenças significativas entre os sexos $(p \leq 0,05)$, entre as faixas etárias $(p \leq 0,05)$ e entre as empresas $(p \leq 0,05)$ (Anexo $7.5-$ Tabela 37).

Quanto às respostas mais diretas sobre se a exposição aos gases/vapores das tintas/velaturas é perigosa (grupo 4 alínea d) do questionário), 48,6 \% indica que "concorda", 34,5\% "concorda totalmente", 6,3 \% indica "sem opinião", 3,5 \% "nem concorda, nem discorda", 2,8 \% "discorda", 2,8 \% "não aplicável" e 1,4 \% "discorda totalmente". O teste Mann Whitney, revelou que não existem diferenças significativas, entre os diferentes tipos de produção $(p=0,834 ; \alpha=0,05)$ e entre as habilitações literárias ( $p=0,525 ; \alpha=0,05)$. No entanto, revelou que existem diferenças significativas entre os sexos ( $p \leq$ $0,05)$, entre as faixas etárias $(p \leq 0,05)$ e entre as empresas $(p \leq 0,05)$ (Anexo 7.5 - Tabela 38). 
Em relação às respostas sobre se a exposição aos gases/vapores dos vernizes ser perigosa (grupo 4 alínea e) do questionário), 53,9\% indica que "concorda", 36,2 \% "concorda totalmente", 4,3 \% indica "sem opinião", 2,1 \% "nem concorda, nem discorda", 2,1 \% "não aplicável" e 1,4\% "discorda totalmente". O teste Mann Whitney, revelou que não existem diferenças significativas, entre os diferentes tipos de produção $(p=0,364 ; \alpha=0,05)$, entre as faixas etárias $(p=0,277 ; \alpha=0,05)$ e entre as habilitações literárias $(p=0,745$; $\alpha=0,05)$. No entanto, revelou que existem diferenças significativas entre os sexos $(p \leq 0,05)$ e entre as empresas $(p \leq 0,05)$ (Anexo 7.5 - Tabela 39).

$\mathrm{Na}$ classificação sobre se a exposição aos gases/vapores do tapa poros ser perigosa (grupo 4 alínea f) do questionário), 52,5\% indica que "concorda", $34,0 \%$ "concorda totalmente", 5,0 \% "nem concorda, nem discorda", 4,3\% indica "sem opinião", 2,8 \% "não aplicável" e 1,4 \% "discorda totalmente". O teste Mann Whitney, revelou que não existem diferenças significativas, entre os diferentes tipos de produção $(p=0,828 ; \alpha=0,05)$, entre as faixas etárias $(p=0,258 ; \alpha=0,05)$ e entre as habilitações literárias $(p=0,865 ; \alpha=0,05)$. No entanto, revelou que existem diferenças significativas entre os sexos $(p \leq 0,05)$ e entre as empresas $(p \leq 0,05)$ (Anexo 7.5 - Tabela 40).

Se não existe risco se a exposição for por pouco tempo (grupo 4 alínea g) do questionário), 33,6 \% dos inquiridos "discorda", 27,1 \% indica que "concorda", $17,1 \%$ "nem concorda, nem discorda", 9,3\% "discorda totalmente", 5,7 \% "concorda totalmente", 5,0 \% indica "sem opinião" e 2,1 \% "não aplicável". O teste Mann Whitney, revelou que não existem diferenças significativas, entre os diferentes tipos de produção $(p=0,171 ; \alpha=0,05)$, entre os sexos $(p=0,303$; $\alpha=0,05)$, entre as faixas etárias $(p=0,073 ; \alpha=0,05)$ e entre as habilitações literárias $(p=0,131 ; \alpha=0,05)$. No entanto, revelou que existem diferenças significativas entre as empresas $(p \leq 0,05)$ (Anexo 7.5 - Tabela 41).

Se a exposição a estes produtos pode provocar doenças (grupo 4 alínea h) do questionário), 44,3 \% indica que "concorda", 39,3 \% "concorda totalmente", 7,1 \% "nem concorda, nem discorda", 2,9 \% indica "sem opinião", 2,1 \% dos inquiridos "discorda", 2,1 \% "discorda totalmente" e 2,1 \% "não aplicável". O teste Mann Whitney, revelou que não existem diferenças significativas, entre os 
diferentes tipos de produção $(p=0,752 ; \alpha=0,05)$, entre os sexos $(p=0,111$; $\alpha=0,05)$, entre as faixas etárias $(p=0,258 ; \alpha=0,05)$ e entre as habilitações literárias $(p=0,559 ; \alpha=0,05)$. No entanto, revelou que existem diferenças significativas entre as empresas $(p \leq 0,05)$ (Anexo 7.5 - Tabela 42).

$\mathrm{Na}$ classificação se a exposição a estes produtos não provoca danos para a saúde (grupo 4 alínea i) do questionário), 37,6 \% dos inquiridos "discorda", 27,7\% "discorda totalmente", 9,9\% "nem concorda, nem discorda", 9,9\% indica que "concorda", 8,5 \% "concorda totalmente", 4,3 \% indica "sem opinião" e 2,1 \% "não aplicável". O teste Mann Whitney, revelou que não existem diferenças significativas, entre os diferentes tipos de produção $(p=0,380 ; \alpha=0,05)$ e entre os sexos $(p=0,095 ; \alpha=0,05)$. No entanto, revelou que existem diferenças significativas entre as empresas $(p \leq 0,05)$, entre as faixas etárias $(p \leq 0,05)$ e entre as habilitações literárias $(p \leq 0,05)$ (Anexo 7.5 - Tabela 43). 


\subsubsection{Utilização de Equipamentos de Proteção Individual}

Relativamente à utilização de equipamentos de proteção individual (Figura 20), observa-se que a média das respostas situa-se entre o "discordo totalmente" e o "discordo" sobre o facto dos colegas de trabalho acharem que não é preciso usar máscara na manipulação de tintas/velaturas, tapa poros e vernizes. A mesma média se aplica às respostas acerca da substituição da máscara só depois de terminar o trabalho e quanto ao facto de utilizarem a máscara que estiver disponível. Situa-se também entre o "discordo totalmente" e o "discordo" sobre o conhecimento de quantas vezes podem usar o filtro da máscara. Em média os trabalhadores também respondem das entre o "discordo totalmente" e o "discordo" acerca do gosto pelo cheiro das tintas/velaturas, tapa poros e vernizes. Os trabalhadores em média "discordam" ou "nem concordam, nem discordam" que as máscaras que Ihes forneceram sejam as mais adequadas. Também "discordam" ou "nem concordam, nem discordam" que saibam quando substituir os filtros e fazer a manutenção à máscara, sobre a necessidade de saber mais para utilizar corretamente a máscara, sobre saber distinguir os vários filtros das máscaras e sobre a necessidade de aprender mais para escolher a máscara de proteção mais eficaz. A média das respostas centra-se entre o "nem concordo, nem discordo" e o "concordo" para as respostas sobre thes terem fornecido máscaras de proteção respiratória para a manipulação de tintas/velaturas, tapa poros e vernizes, saberem utilizar corretamente as máscaras de proteção, por vezes a máscara fica estragada e que quando a máscara fica danificada substituem-na imediatamente. 


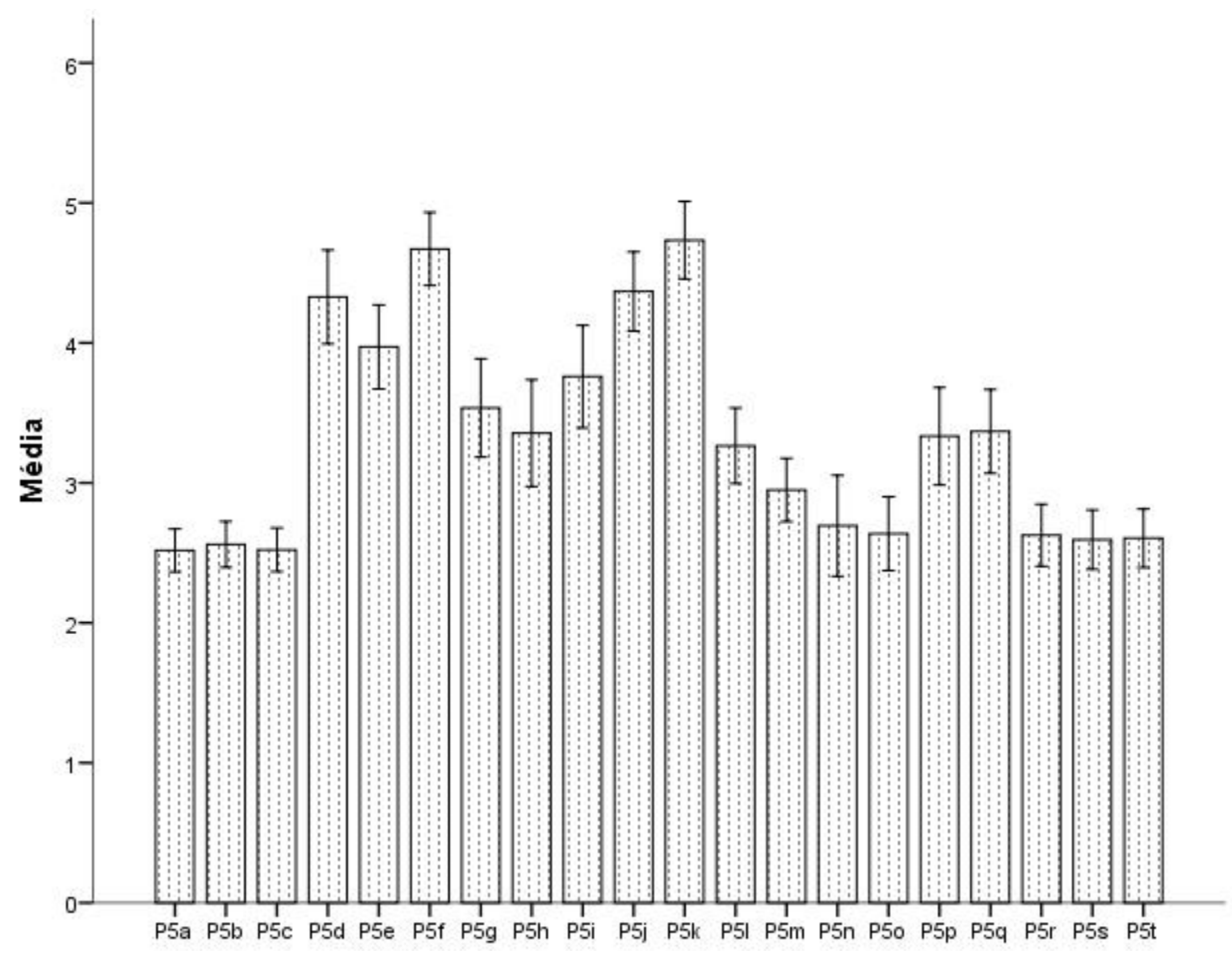

Figura 20 - Média das respostas ( 0 - não aplicável; 1 - sem opinião; 2 - discordo totalmente; 3 - discordo; 4 - nem concordo, nem discordo; 5 - concordo; 6 - concordo totalmente) sobre a Utilização de Máscara de Proteção: os meus colegas acham que não é necessário usar máscara na manipulação de tintas/velaturas (5a); os meus colegas acham que não é necessário usar máscara na manipulação do tapa poros (5b); os meus colegas acham que não é necessário usar máscara na manipulação de vernizes (5c); deram-me máscara de proteção respiratória para a manipulação de tintas/velaturas, vernizes e tapa poros (5d); penso que as máscaras que me deram são as mais adequadas (5e); sei utilizar a máscara corretamente (5f); as máscaras para gases e vapores são as mais adequadas para a manipulação de tintas/velaturas, vernizes e tapa poros (5g); sei quando tenho de substituir os filtros da minha máscara (5h); sei como fazer a manutenção/limpeza da minha máscara (5i); por vezes a minha máscara fica estragada (5j); quando a minha máscara está danificada substituo-a imediatamente (5k); preciso saber mais para utilizar corretamente a máscara (5I); quando a minha máscara está estragada espero que termine o trabalho para a substituir $(5 \mathrm{~m})$; sei quantas vezes posso usar o filtro da minha máscara (5n); utilizo a máscara que estiver disponível (5o); sei distinguir os vários tipos de máscaras de proteção (5p); preciso aprender mais para escolher a máscara de proteção mais eficaz (5q); gosto do cheiro das tintas/velatura (5r); gosto do cheiro a tapa poros (5s); gosto do cheiro dos vernizes $(5 t)$ 
$\mathrm{Na}$ classificação sobre se os colegas de trabalhado acham que não é necessário usar máscara na manipulação de tintas/velaturas (grupo 5 alínea a) do questionário), 50,4 \% "discorda", 34,0\% "discorda totalmente", 6,4 \% indica "sem opinião", 3,5 \% indica que "concorda", 3,5 \% "não aplicável" e 2,1 \% "nem concorda, nem discorda". O teste Mann Whitney, revelou que não existem diferenças significativas, entre os diferentes tipos de produção $(p=0,177$; $\alpha=0,05)$, entre os sexos $(p=0,132 ; \alpha=0,05)$, entre as faixas etárias $(p=0,923$; $\alpha=0,05)$ e entre as habilitações literárias $(p=0,732 ; \alpha=0,05)$. No entanto, revelou que existem diferenças significativas entre as empresas $(p \leq 0,05)$ (Anexo $7.6-$ Tabela 44).

$\mathrm{Na}$ classificação sobre se os colegas de trabalhado acham que não é necessário usar máscara na manipulação do tapa poros (grupo 5 alínea b) do questionário), 51,8\% "discorda", 29,8\% "discorda totalmente", 7,8 \% indica "sem opinião", 5,0 \% indica que "concorda", 3,5 \% "não aplicável" e 2,1 \% "nem concorda, nem discorda". O teste Mann Whitney, revelou que não existem diferenças significativas, entre as empresas $(p=0,358 ; \alpha=0,05)$, entre os sexos $(p=0,703 ; \alpha=0,05)$, entre as faixas etárias $(p=0,962 ; \alpha=0,05)$ e entre as habilitações literárias $(p=0,765 ; \alpha=0,05)$. No entanto, revelou que existem diferenças significativas entre os diferentes tipos de produção $(p \leq 0,05)$ (Anexo 7.6 - Tabela 45).

Quanto à classificação sobre se os colegas de trabalhado acham que não é necessário usar máscara na manipulação de vernizes (grupo 5 alínea c) do questionário), 55,0 \% "discorda", 29,3\% "discorda totalmente", 7,8 \% indica "sem opinião", 3,6 \% "não aplicável", 2,1 \% indica que "concorda", 1,4 \% "nem concorda, nem discorda" e 0,7 \% "concorda totalmente". O teste Mann Whitney, revelou que não existem diferenças significativas, entre as empresas $(p=0,07$; $\alpha=0,05)$, entre os sexos $(p=0,598 ; \alpha=0,05)$, entre as faixas etárias $(p=0,967$; $\alpha=0,05)$ e entre as habilitações literárias $(p=0,545 ; \alpha=0,05)$. No entanto, revelou que existem diferenças significativas entre os diferentes tipos de produção ( $p \leq$ 0,05) (Anexo 7.6 - Tabela 46). 
Sobre se a empresa lhes forneceu a máscara de proteção respiratória para a manipulação de tintas/velaturas, vernizes e tapa poros (grupo 5 alínea d) do questionário), 54,3 \% indica que "concorda", 23,6 \% "concorda totalmente", 14,3 \% "não aplicável", 3,6 \% indica "sem opinião", 3,6 \% "nem concorda, nem discorda" e 0,7 \% "discorda". O teste Mann Whitney, revelou que não existem diferenças significativas, entre as faixas etárias $(p=0,333 ; \alpha=0,05)$ e entre as habilitações literárias $(p=0,519 ; \alpha=0,05)$. No entanto, revelou que existem diferenças significativas entre as empresas $(p \leq 0,05)$, entre os diferentes tipos de produção $(p \leq 0,05)$ e entre os sexos $(p \leq 0,05)$ (Anexo 7.6 - Tabela 47).

Acerca do sentimento se as máscaras que lhes forneceram sejam as mais adequadas (grupo 5 alínea e) do questionário), 40,7 \% indica que "concorda", $17,9 \%$ "nem concorda, nem discorda", 14,3 \% "concorda totalmente", 12,9 \% indica "sem opinião", 6,4 \% "discorda", 5,7 \% "não aplicável" e 2,1% "discorda totalmente". O teste Mann Whitney, revelou que não existem diferenças significativas, entre os diferentes tipos de produção $(p=0,091 ; \alpha=0,05)$, entre as faixas etárias $(p=0,196 ; \alpha=0,05)$ e entre as habilitações literárias $(p=0,225$; $\alpha=0,05)$. No entanto, revelou que existem diferenças significativas entre as empresas $(p \leq 0,05)$ e entre os sexos $(p \leq 0,05)$ (Anexo 7.6 - Tabela 48).

Claramente 65,0 \% "concorda", que se sabe utilizar a máscara corretamente (grupo 5 alínea f) do questionário), 20,7 \% "concorda totalmente", 6,4 \% "não aplicável", 3,6 \% indica "sem opinião", 2,1 \% "nem concorda, nem discorda", 1,4 \% "discorda" e 0,7 \% "discorda totalmente". O teste Mann Whitney, revelou que não existem diferenças significativas, entre os diferentes tipos de produção $(p=0,375 ; \alpha=0,05)$, entre as faixas etárias $(p=0,978 ; \alpha=0,05)$ e entre as habilitações literárias $(p=0,676 ; \alpha=0,05)$. No entanto, revelou que existem diferenças significativas entre as empresas $(p \leq 0,05)$ e entre os sexos $(p \leq 0,05)$ (Anexo 7.6 - Tabela 49).

Quanto à afirmação se as máscaras para gases e vapores são as mais adequadas para a manipulação de tintas/velaturas, vernizes e tapa poros (grupo 5 alínea g) do questionário), 38,6 \% "concorda", 19,3 \% indica "sem opinião", 13,6 \% "concorda totalmente", 11,4 \% "não aplicável", 10,0 \% "nem concorda, nem discorda", 5,7 \% "discorda" e 1,4\% "discorda totalmente". O teste Mann 
Whitney, revelou que não existem diferenças significativas, entre as faixas etárias $(p=0,654 ; \alpha=0,05)$ e entre as habilitações literárias $(p=0,626 ; \alpha=0,05)$. No entanto, revelou que existem diferenças significativas entre as empresas $(p \leq$ $0,05)$, entre os diferentes tipos de produção $(p \leq 0,05)$ e entre os sexos $(p \leq 0,05)$ (Anexo 7.6 - Tabela 50).

Da amostra, 45,7 \% "concorda", que sabe quando tem de substituir os filtros da máscara, (grupo 5 alínea h) do questionário), 21,7 \% "não aplicável", 13,0 \% "sem opinião", 9,4 \% "concorda totalmente", 7,2 \% "nem concorda, nem discorda" e 2,9 \% "discorda". O teste Mann Whitney, revelou que não existem diferenças significativas, entre os diferentes tipos de produção $(p=0,052$; $\alpha=0,05)$, entre as faixas etárias $(p=0,539 ; \alpha=0,05)$ e entre as habilitações literárias $(p=0,430 ; \alpha=0,05)$. No entanto, revelou que existem diferenças significativas entre as empresas $(p \leq 0,05)$ e entre os sexos $(p \leq 0,05)$ (Anexo 7.6 - Tabela 51).

Em relação à manutenção das máscaras (grupo 5 alínea i) do questionário), 47,4 \% "concorda", que sabe fazê-lo, 15,3\% "concorda totalmente", 15,3 \% "não aplicável", 12,4 \% "sem opinião", 6,6 \% "nem concorda, nem discorda", 2,2 \% "discorda" e 0,7 \% "discorda totalmente". O teste Mann Whitney, revelou que não existem diferenças significativas, entre as empresas $(p=0,228 ; \alpha=0,05)$, entre os diferentes tipos de produção $(p=0,622 ; \alpha=0,05)$, entre as faixas etárias $(p=0,774 ; \alpha=0,05)$ e entre as habilitações literárias $(p=0,560 ; \alpha=0,05)$. No entanto, revelou que existem diferenças significativas entre os sexos $(p \leq 0,05)$ (Anexo 7.6 - Tabela 52).

Quanto ao facto de por vezes a máscara ficar danificada (grupo 5 alínea j) do questionário), 64,0 \% "concorda", 12,5 \% "concorda totalmente", 7,4 \% "não aplicável", 5,9 \% "sem opinião", 5,1\% "nem concorda, nem discorda" e 5,1\% "discorda". O teste Mann Whitney, revelou que não existem diferenças significativas, entre os diferentes tipos de produção $(p=0,628 ; \alpha=0,05)$, entre os sexos $(p=0,130 ; \alpha=0,05)$, entre as faixas etárias $(p=0,615 ; \alpha=0,05)$ e entre as habilitações literárias $(p=0,313 ; \alpha=0,05)$. No entanto, revelou que existem diferenças significativas entre as empresas $(p \leq 0,05)$ (Anexo 7.6 - Tabela 53). 
Se a substituem imediatamente (grupo 5 alínea k) do questionário), 52,5 \% "concorda", 30,9 \% "concorda totalmente", 7,9 \% "não aplicável", 3,6 \% "nem concorda, nem discorda", 2,9 \% "discorda" e 2,2 \% "sem opinião". O teste Mann Whitney, revelou que não existem diferenças significativas, entre os diferentes tipos de produção $(p=0,346 ; \alpha=0,05)$, entre as faixas etárias $(p=0,845 ; \alpha=0,05)$ e entre as habilitações literárias $(p=0,607 ; \alpha=0,05)$. No entanto, revelou que existem diferenças significativas entre as empresas $(p \leq 0,05)$ e entre os sexos $(p \leq 0,05)$ (Anexo 7.6 - Tabela 54).

Dos inquiridos, 31,6\% "discorda" que precisa saber mais para utilizar corretamente a máscara (grupo 5 alínea I) do questionário), 22,8 \% "concorda", 19,1 \% "nem concorda, nem discorda", 13,2 \% "sem opinião", 6,6 \% "não aplicável", 3,7 \% "concorda totalmente" e 3,0 \% "discorda totalmente". O teste Mann Whitney, revelou que não existem diferenças significativas, entre as empresas ( $p=0,164 ; \alpha=0,05)$, entre os diferentes tipos de produção ( $p=0,866$; $\alpha=0,05)$, entre os sexos $(p=0,399 ; \alpha=0,05)$, entre as faixas etárias $(p=0,113$; $\alpha=0,05)$ e entre as habilitações literárias $(p=0,436 ; \alpha=0,05)$ (Anexo 7.6 - Tabela 55)

A maioria da amostra, 55,1 \% "discorda" que espere que termine o trabalho para substituir a máscara danificada (grupo 5 alínea $\mathrm{m}$ ) do questionário), 13,2 \% "discorda totalmente", 9,6 \% "nem concorda, nem discorda", 8,8 \% "não aplicável", 7,4 \% "concorda", 4,4 \% "concorda totalmente" e $1,5 \%$ "sem opinião". O teste Mann Whitney, revelou que não existem diferenças significativas, entre as empresas $(p=0,935 ; \alpha=0,05)$, entre os diferentes tipos de produção $(p=0,789 ; \alpha=0,05)$, entre os sexos $(p=0,145$; $\alpha=0,05)$, entre as faixas etárias $(p=0,962 ; \alpha=0,05)$ e entre as habilitações literárias $(p=0,204 ; \alpha=0,05)$ (Anexo 7.6 - Tabela 56).

Quanto à afirmação "sei quantas vezes posso usar o filtro da minha máscara" (grupo 5 alínea n) do questionário), 25,5 \% "concorda", 23,4 \% "não aplicável", 20,4 \% "sem opinião", 14,6 \% "nem concorda, nem discorda", 7,3 \% "discorda", 5,8 \% "concorda totalmente" e 2,9 \% "discorda totalmente". O teste Mann Whitney, revelou que não existem diferenças significativas, entre os diferentes tipos de produção $(p=0,175 ; \alpha=0,05)$, entre as faixas etárias $(p=0,169$; 
$\alpha=0,05)$ e entre as habilitações literárias $(p=0,282 ; \alpha=0,05)$. No entanto, revelou que existem diferenças significativas entre as empresas $(p \leq 0,05)$ e entre os sexos $(p \leq 0,05)$ (Anexo 7.6 - Tabela 57 ).

Da amostra, 40,6 \% "discorda" que utiliza a máscara que estiver disponível (grupo 5 alínea o) do questionário), 18,1 \% "discorda totalmente", 14,5 \% "não aplicável", 10,9 \% "concorda", 6,5 \% "sem opinião", 5,8 \% "nem concorda, nem discorda" e 3,6 \% "concorda totalmente". O teste Mann Whitney, revelou que não existem diferenças significativas, entre as empresas $(p=0,122$; $\alpha=0,05)$, entre os diferentes tipos de produção $(p=0,347 ; \alpha=0,05)$, entre os sexos $(p=0,313 ; \alpha=0,05)$, entre as faixas etárias $(p=0,318 ; \alpha=0,05)$ e entre as habilitações literárias $(p=0,443 ; \alpha=0,05)$ (Anexo 7.6 - Tabela 58).

Relativamente ao comentário dos inquiridos quanto à afirmação: "sei distinguir os vários tipos de máscaras de proteção" (grupo 5 alínea p) do questionário), 34,1 \% "concorda", 15,6 \% "nem concorda, nem discorda", 23,0 \% "sem opinião", 10,4 \% "não aplicável", 9,6 \% "concorda totalmente", 5,2 \% "discorda", 2,2 \% "discorda totalmente". O teste Mann Whitney, revelou que não existem diferenças significativas, entre os diferentes tipos de produção $(p=0,215$; $\alpha=0,05)$, entre os sexos $(p=0,063 ; \alpha=0,05)$, entre as faixas etárias $(p=0,203$; $\alpha=0,05)$ e entre as habilitações literárias $(p=0,755 ; \alpha=0,05)$. No entanto, revelou que existem diferenças significativas entre as empresas $(p \leq 0,05)$ (Anexo $7.6-$ Tabela 59).

Quanto à necessidade de aprenderem mais para escolher a máscara de proteção mais eficaz (grupo 5 alínea q) do questionário), 26,5 \% "concorda", 21,3 \% "discorda", 18,4 \% "nem concorda, nem discorda", 14,0 \% "sem opinião", 8,1 \% "não aplicável", 7,4 \% "concorda totalmente", 4,4 \% "discorda totalmente". O teste Mann Whitney, revelou que não existem diferenças significativas, entre os diferentes tipos de produção $(p=0,089 ; \alpha=0,05)$, entre os sexos $(p=0,126$; $\alpha=0,05)$ e entre as faixas etárias $(p=0,184 ; \alpha=0,05)$. No entanto, revelou que existem diferenças significativas entre as empresas $(p \leq 0,05)$ e entre as habilitações literárias $(p \leq 0,05)$ (Anexo 7.6 - Tabela 60). 
Sobre o gosto pelo cheiro das tintas/velaturas (grupo 5 alínea $r$ ) do questionário), 37,4 \% "discorda", 24,5 \% "discorda totalmente", 12,9 \% "nem concorda, nem discorda", 10,8 \% "sem opinião", 7,2 \% "não aplicável”, 4,3% "concorda", 2,9 \% "concorda totalmente". O teste Mann Whitney, revelou que não existem diferenças significativas, entre os diferentes tipos de produção $(p=0,134$; $\alpha=0,05)$, entre os sexos $(p=0,569 ; \alpha=0,05)$ e entre as habilitações literárias $(p=0,192 ; \alpha=0,05)$. No entanto, revelou que existem diferenças significativas entre as empresas $(p \leq 0,05)$ e entre as faixas etárias $(p \leq 0,05)$ (Anexo 7.6 Tabela 61).

Em relação ao gosto pelo cheiro do tapa poros (grupo 5 alínea s) do questionário), 39,1 \% “discorda", 24,6 \% “discorda totalmente", 13,0 \% "nem concorda, nem discorda", 10,1 \% "sem opinião", 7,2 \% "não aplicável”, 4,3% "concorda", 1,4 \% "concorda totalmente". O teste Mann Whitney, revelou que não existem diferenças significativas, entre os diferentes tipos de produção ( $p=0,324$; $\alpha=0,05)$, entre os sexos $(p=0,121 ; \alpha=0,05)$ e entre as habilitações literárias $(p=0,070 ; \alpha=0,05)$. No entanto, revelou que existem diferenças significativas entre as empresas $(p \leq 0,05)$ e entre as faixas etárias $(p \leq 0,05)$ (Anexo 7.6 Tabela 62).

No gosto pelo cheiro dos vernizes (grupo 5 alínea t) do questionário), 39,6 \% "discorda", 24,5 \% "discorda totalmente", 13,7 \% "nem concorda, nem discorda", 10,8 \% "sem opinião", 6,5 \% "não aplicável", 2,8 \% "concorda", 2,1 \% "concorda totalmente". O teste Mann Whitney, revelou que não existem diferenças significativas, entre os diferentes tipos de produção $(p=0,400$; $\alpha=0,05)$, entre os sexos $(p=0,121 ; \alpha=0,05)$ e entre as habilitações literárias $(p=0,187 ; \alpha=0,05)$. No entanto, revelou que existem diferenças significativas entre as empresas $(p \leq 0,05)$ e entre as faixas etárias $(p \leq 0,05)$ (Anexo $7.6-$ Tabela 63). 
Este conjunto de respostas refere-se à utilização de luvas de proteção. Observa-se que a média de todas as respostas situa-se entre o "nem concordo, nem discordo" e o "concordo" (Figura 21).

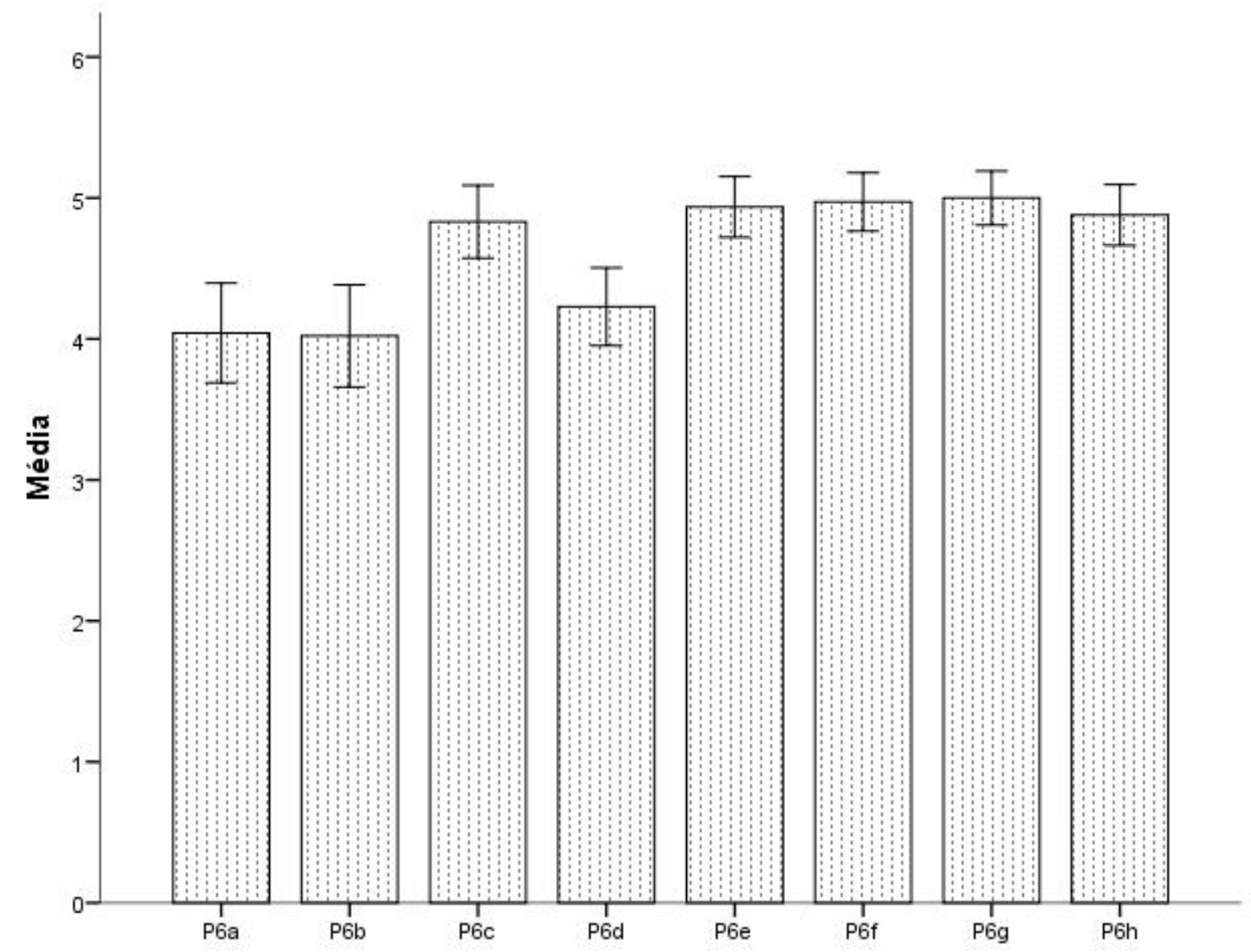

Figura 21 - Média das respostas ( 0 - não aplicável; 1 - sem opinião; 2 - discordo totalmente; 3 - discordo; 4 - nem concordo, nem discordo; 5 - concordo; 6 - concordo totalmente) sobre a

Utilização de Luvas de Proteção: deram-me luvas de proteção para a manipulação de tintas/velaturas, vernizes e tapa poros (6a); uso as luvas para a manipulação de tintas/velaturas, vernizes e tapa poros (6b); o contato das tintas/velaturas, vernizes e tapa poros com a pele é perigoso (6c); penso que as luvas que me deram são as mais adequadas (6d); sei utilizar as luvas corretamente (6e); quando as luvas estão danificadas substituo-as imediatamente (6f); quando preciso tenho sempre disponível luvas de substituição (6g); uso sempre as luvas (6h)

A maioria dos trabalhadores, 57,7 \% "concorda" que lhe deram luvas de proteção (grupo 6 alínea a) do questionário), 19,0 \% "não aplicável”, 16,2% "concorda totalmente", 2,1 \% "sem opinião", 2,1 \% "nem concorda, nem 
discorda", 2,1\% "discorda", 0,7 \% "discorda totalmente". O teste Mann Whitney, revelou que não existem diferenças significativas, entre as faixas etárias $(p=0,293 ; \alpha=0,05)$ e entre as habilitações literárias $(p=0,056 ; \alpha=0,05)$. No entanto, revelou que existem diferenças significativas entre as empresas ( $p \leq$ $0,05)$, entre os diferentes tipos de produção $(p \leq 0,05)$ e entre os sexos $(p \leq 0,05)$ (Anexo 7.6 - Tabela 64).

Quanto ao facto de usarem as luvas para a manipulação de tintas/velaturas, vernizes e tapa poros (grupo 6 alínea b) do questionário), 52,1 \% "concorda" que usa, 19,3 \% "concorda totalmente", 19,3 \% "não aplicável", 4,3 \% "nem concorda, nem discorda", 2,9 \% "sem opinião", 1,4 \% "discorda”, 0,7 \% "discorda totalmente". O teste Mann Whitney, revelou que não existem diferenças significativas, entre as faixas etárias $(p=0,494 ; \alpha=0,05)$ e entre as habilitações literárias $(p=0,104 ; \alpha=0,05)$. No entanto, revelou que existem diferenças significativas entre as empresas $(p \leq 0,05)$, entre os diferentes tipos de produção $(p \leq 0,05)$ e entre os sexos $(p \leq 0,05)$ (Anexo 7.6 - Tabela 65).

Se consideram que o contato destes produtos com a pele é perigoso (grupo 6 alínea c) do questionário), 48,6 \% "concorda", 35,2 \% "concorda totalmente", 4,9 \% "não aplicável", 4,2 \% "nem concorda, nem discorda", 4,2 \% "sem opinião", 2,1 \% "discorda", 0,7 \% "discorda totalmente". O teste Mann Whitney, revelou que não existem diferenças significativas, entre as faixas etárias $(p=0,798 ; \alpha=0,05)$ e entre as habilitações literárias $(p=0,657 ; \alpha=0,05)$. No entanto, revelou que existem diferenças significativas entre as empresas ( $p \leq$ $0,05)$, entre os diferentes tipos de produção $(p \leq 0,05)$ e entre os sexos $(p \leq 0,05)$ (Anexo 7.6 - Tabela 66).

Em relação à opinião se a luvas que lhes deram eram as mais adequadas (grupo 6 alínea d) do questionário), 57,1 \% "concorda", 12,9 \% "nem concorda, nem discorda", 10,7 \% "concorda totalmente", 10,7 \% "sem opinião", 4,3 \% "não aplicável", 2,1 \% “discorda", 2,1 \% "discorda totalmente". O teste Mann Whitney, revelou que não existem diferenças significativas, entre as empresas ( $p=0,051$; $\alpha=0,05)$, entre os diferentes tipos de produção $(p=0,357 ; \alpha=0,05)$, entre as faixas etárias $(p=0,692 ; \alpha=0,05)$, entre as habilitações literárias $(p=0,619 ; \alpha=0,05)$ e entre os sexos $(p=0,123 ; \alpha=0,05)$ (Anexo 7.6 - Tabela 67). 
Se sabem usar corretamente as luvas de proteção (grupo 6 alínea e) do questionário), 62,4 \% "concorda", 10,7 \% "concorda totalmente", 3,5\% "sem opinião", 2,8 \% "não aplicável", 2,1 \% "nem concorda, nem discorda", 0,7 \% "discorda", 0,7 \% "discorda totalmente". O teste Mann Whitney, revelou que não existem diferenças significativas, entre as empresas ( $p=0,390 ; \alpha=0,05)$, entre as faixas etárias $(p=0,857 ; \alpha=0,05)$ e entre as habilitações literárias $(p=0,164$; $\alpha=0,05)$. No entanto, revelou que existem diferenças significativas entre os diferentes tipos de produção $(p \leq 0,05)$ e entre os sexos $(p \leq 0,05)$ (Anexo $7.6-$ Tabela 68).

Quando as luvas estão danificadas, 61,3\% "concorda" que as substitui imediatamente (grupo 6 alínea f) do questionário), 28,9\% "concorda totalmente", 2,8 \% "sem opinião", 2,8 \% "não aplicável", 2,1 \% "nem concorda, nem discorda" e 2,1 \% "discorda". O teste Mann Whitney, revelou que não existem diferenças significativas, entre os diferentes tipos de produção $(p=0,349 ; \alpha=0,05)$, entre os sexos $(p=0,055 ; \alpha=0,05)$, entre as faixas etárias $(p=0,967 ; \alpha=0,05)$ e entre as habilitações literárias $(p=0,494 ; \alpha=0,05)$. No entanto, revelou que existem diferenças significativas entre as empresas $(p \leq 0,05)$ (Anexo 7.6 - Tabela 69).

Se existem luvas de substituição (grupo 6 alínea g) do questionário), 55,3 \% "concorda", 31,2 \% "concorda totalmente", 5,7 \% "nem concorda, nem discorda", 2,8 \% "discorda", 2,1 \% "discorda totalmente", 2,1 \% "não aplicável" e $0,7 \%$ "sem opinião". O teste Mann Whitney, revelou que não existem diferenças significativas, entre as empresas $(p=0,056 ; \alpha=0,05)$, entre os diferentes tipos de produção ( $p=0,421 ; \alpha=0,05)$, entre os sexos ( $p=0,125 ; \alpha=0,05)$, entre as faixas etárias $(p=0,741 ; \alpha=0,05)$ e entre as habilitações literárias $(p=0,662 ; \alpha=0,05)$ (Anexo 7.6 - Tabela 70).

A maioria dos inquiridos, $51,1 \%$ "concorda", que usa sempre as luvas (grupo 6 alínea h) do questionário), 30,5\% "concorda totalmente", 7,1 \% "nem concorda, nem discorda", 6,4 \% "discorda", 2,8 \% "não aplicável" e 2,1% "sem opinião". O teste Mann Whitney, revelou que não existem diferenças significativas, entre os diferentes tipos de produção $(p=0,266 ; \alpha=0,05)$, entre os sexos $(p=0,278 ; \alpha=0,05)$, entre as faixas etárias $(p=0,205 ; \alpha=0,05)$ e entre as 
habilitações literárias $(p=0,693 ; \alpha=0,05)$. No entanto, revelou que existem diferenças significativas entre as empresas $(p \leq 0,05)$ (Anexo 7.6 - Tabela 71).

Os inquiridos classificam em média entre os "discordo totalmente" e o "discordo" sobre se thes deram fato de proteção para a manipulação de tintas/velaturas, vernizes e tapa poros, se pensam que o fato que thes deram para a manipulação de tintas/velaturas, vernizes e tapa poros é o mais adequado, se $\circ$ fato têm $\circ$ tamanho adequado, sabem utilizar $\circ$ fato corretamente, quando o fato está danificado substituem-no imediatamente e quando necessitam têm sempre disponível um fato de substituição. Em média respondem "sem opinião" ou "discordo totalmente" em relação à afirmação se no verão não usam fato de proteção (Figura 22).

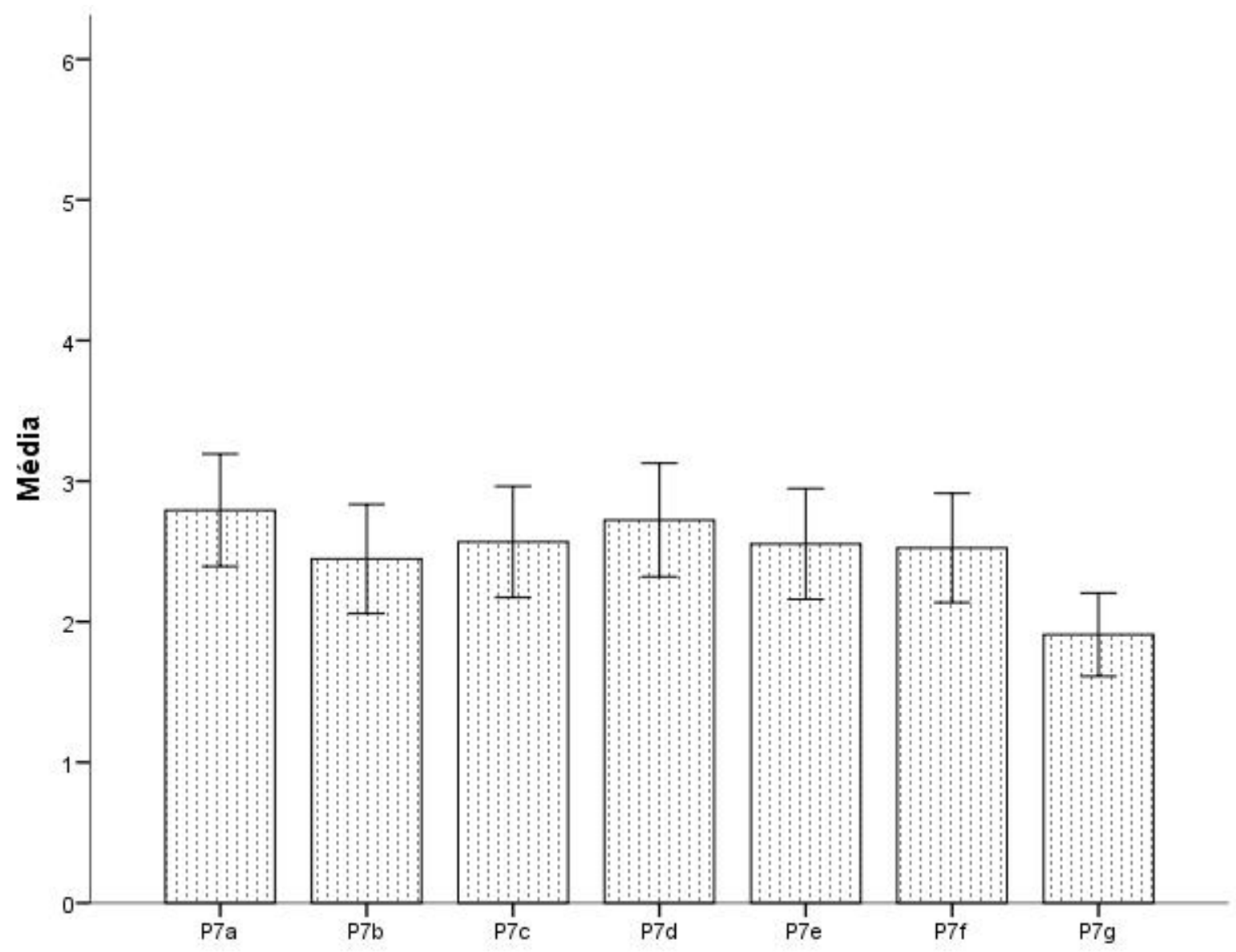

Figura 22 - Média das respostas ( 0 - não aplicável; 1 - sem opinião; 2 - discordo totalmente; 3

- discordo; 4 - nem concordo, nem discordo; 5 - concordo; 6 - concordo totalmente) sobre a Utilização de Fato de Proteção: deram-me fato de proteção para a manipulação de 
tintas/velaturas, vernizes e tapa poros (7a); penso que o fato que me deram para a manipulação de tintas/velaturas, vernizes e tapa poros é o mais adequado (7b); o fato têm o tamanho adequado (7c); sei utilizar o fato corretamente (7d); quando o fato está estragado substituo-o imediatamente (7e); quando preciso tenho sempre disponível um fato de substituição (7f); no Verão não uso fato de proteção $(7 \mathrm{~g})$

Dos trabalhadores inquiridos, 31,4 \% considera "não aplicável" a afirmação se Ihe deram fato de proteção para a manipulação de tintas/velaturas, vernizes e tapa poros (grupo 7 alínea a) do questionário), 22,9 \% "concorda", $15,7 \%$ "concorda totalmente", 10,7 \% "sem opinião", 7,9 \% "nem concorda, nem discorda", 5,7\% "discorda" e 5,7\% "discorda totalmente". O teste Mann Whitney, revelou que não existem diferenças significativas, entre as faixas etárias $(p=0,141 ; \alpha=0,05)$ e entre as habilitações literárias $(p=0,218 ; \alpha=0,05)$. No entanto, revelou que existem diferenças significativas entre as empresas ( $p \leq$ $0,05)$, entre os diferentes tipos de produção $(p \leq 0,05)$ e entre os sexos $(p \leq 0,05)$ (Anexo 7.6 - Tabela 72).

Em relação à opinião se a fato que lhes deram ser o mais adequado (grupo 7 alínea b) do questionário), 36,9 \% refere "não aplicável", 23,4 \% "concorda", 12,1 \% "sem opinião", 9,2 \% "concorda totalmente", 9,2 \% "nem concorda, nem discorda", 5,0 \% "discorda" e 4,3\% "discorda totalmente". O teste Mann Whitney, revelou que não existem diferenças significativas, entre as faixas etárias $(p=0,662 ; \alpha=0,05)$ e entre as habilitações literárias $(p=0,746 ; \alpha=0,05)$. No entanto, revelou que existem diferenças significativas entre as empresas ( $p \leq$ $0,05)$, entre os diferentes tipos de produção $(p \leq 0,05)$ e entre os sexos $(p \leq 0,05)$ (Anexo 7.6 - Tabela 73).

Se o fato de proteção tem o tamanho adequado (grupo 7 alínea c) do questionário), 33,3 \% considera "não aplicável", 23,4 \% "concorda", 14,2 \% "sem opinião", 12,8 \% "concorda totalmente", 6,4 \% "nem concorda, nem discorda", $6,4 \%$ "discorda totalmente" e 3,5 \% "discorda". O teste Mann Whitney, revelou que não existem diferenças significativas, entre as faixas etárias $(p=0,229$; $\alpha=0,05)$ e entre as habilitações literárias $(p=0,886 ; \alpha=0,05)$. No entanto, revelou que existem diferenças significativas entre as empresas $(p \leq 0,05)$, entre os 
diferentes tipos de produção $(p \leq 0,05)$ e entre os sexos $(p \leq 0,05)$ (Anexo $7.6-$ Tabela 74).

Se sabem usar corretamente o fato de proteção (grupo 7 alínea d) do questionário), 32,6 \% considera "não aplicável", 29,1 \% "concorda", 14,2 \% "sem opinião", 12,8 \% "concorda totalmente", 5,7 \% "nem concorda, nem discorda", 3,5 \% "discorda totalmente" e 2,1\% "discorda". O teste Mann Whitney, revelou que não existem diferenças significativas, entre as faixas etárias $(p=0,543$; $\alpha=0,05)$ e entre as habilitações literárias $(p=0,728 ; \alpha=0,05)$. No entanto, revelou que existem diferenças significativas entre as empresas ( $p \leq 0,05)$, entre os diferentes tipos de produção $(p \leq 0,05)$ e entre os sexos $(p \leq 0,05)$ (Anexo $7.6-$ Tabela 75).

Quando o fato está danificado, 33,3 \% considera "não aplicável", 22,7 \% "concorda" que o substitui imediatamente (grupo 7 alínea e) do questionário), 15,6 \% "sem opinião", 12,1 \% "concorda totalmente", 8,5 \% "nem concorda, nem discorda", 4,3 \% "discorda" e 3,5\% "discorda totalmente". O teste Mann Whitney, revelou que não existem diferenças significativas, entre as faixas etárias $(p=0,747 ; \alpha=0,05)$ e entre as habilitações literárias $(p=0,579 ; \alpha=0,05)$. No entanto, revelou que existem diferenças significativas entre as empresas ( $p \leq$ $0,05)$, entre os diferentes tipos de produção $(p \leq 0,05)$ e entre os sexos $(p \leq 0,05)$ (Anexo 7.6 - Tabela 76).

Se existe fato de substituição (grupo 7 alínea f) do questionário), 32,6 \% considera "não aplicável", 20,6 \% "concorda", 15,6 \% "sem opinião", 12,8 \% "concorda totalmente", 7,8 \% "discorda", 6,4 \% "nem concorda, nem discorda" e 4,3 \% "discorda totalmente". O teste Mann Whitney, revelou que não existem diferenças significativas, entre as faixas etárias $(p=0,856 ; \alpha=0,05)$ e entre as habilitações literárias $(p=0,644 ; \alpha=0,05)$. No entanto, revelou que existem diferenças significativas entre as empresas $(p \leq 0,05)$, entre os diferentes tipos de produção $(p \leq 0,05)$ e entre os sexos $(p \leq 0,05)$ (Anexo 7.6 - Tabela 77).

Dos inquiridos, 33,3 \% considera "não aplicável", 19,1 \% "discorda" que no verão não usa fato (grupo 7 alínea g) do questionário), 14,2 \% "sem opinião", $13,5 \%$ "discorda totalmente", 9,2 \% "nem concorda, nem discorda", 8,5\% 
"concorda" e 2,1 \% "concorda totalmente". O teste Mann Whitney, revelou que não existem diferenças significativas, entre as faixas etárias $(p=0,324 ; \alpha=0,05)$ e entre as habilitações literárias $(p=0,968 ; \alpha=0,05)$. No entanto, revelou que existem diferenças significativas entre as empresas ( $p \leq 0,05)$, entre os diferentes tipos de produção $(p \leq 0,05)$ e entre os sexos $(p \leq 0,05)$ (Anexo 7.6 Tabela 78).

Acerca da utilização de botas de proteção, a média das respostas centrase entre "discordo totalmente" e o "discordo". Os trabalhadores foram inquiridos sobre se lhes deram botas para a manipulação de tintas/velaturas, vernizes e tapa poros, sobre a sua opinião se as botas que forneceram foram as mais adequadas, se têm o tamanho adequado, se são substituídas imediatamente quando estão danificadas, se há botas de substituição e se usam sempre as botas (Figura 23). 


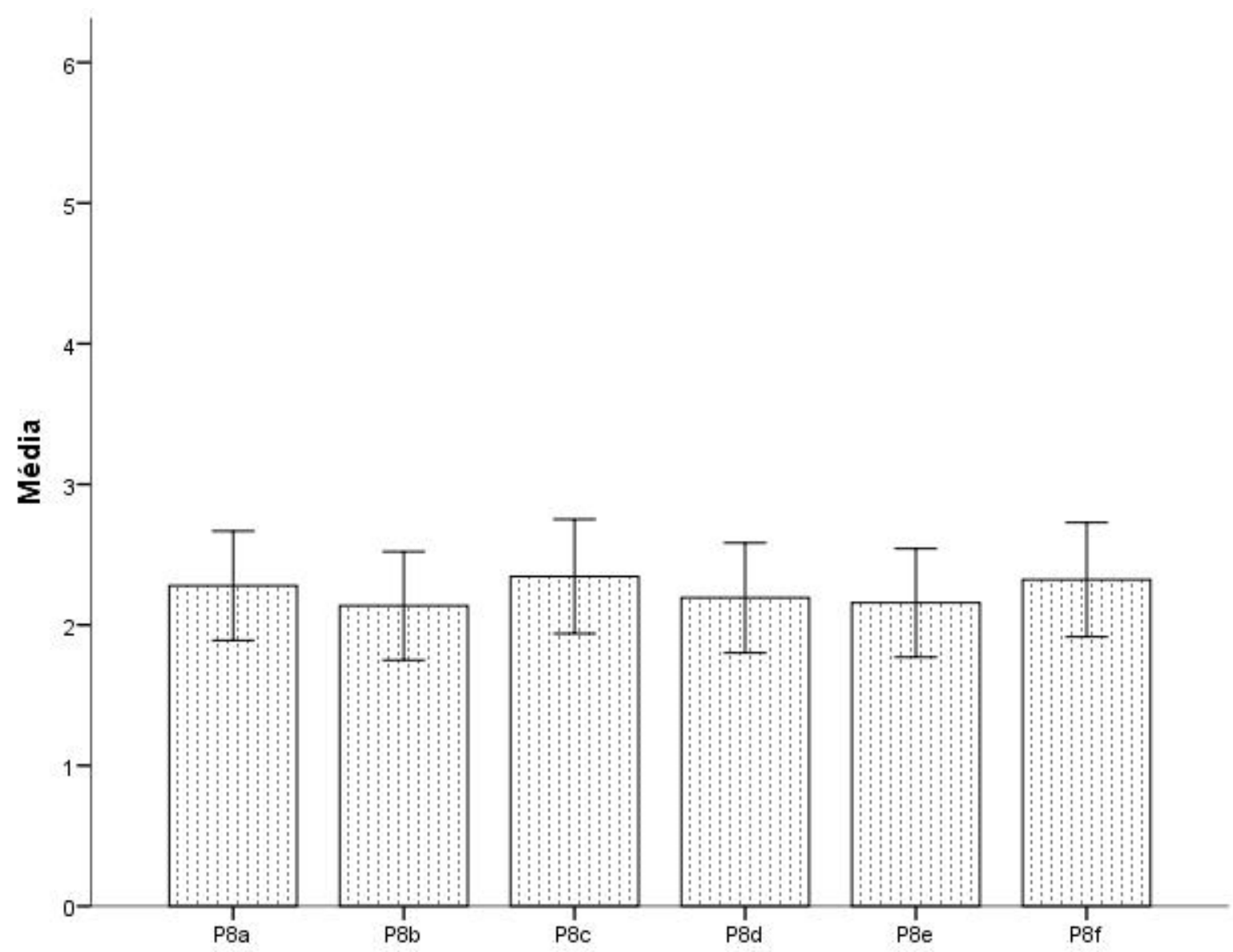

Figura 23 - Média das respostas (0 - não aplicável; 1 - sem opinião; 2 - discordo totalmente; 3 - discordo; 4 - nem concordo, nem discordo; 5 - concordo; 6 - concordo totalmente) sobre a Utilização de Botas de Proteção: deram-me botas para a manipulação de tintas/velaturas, vernizes e tapa poros (8a); penso que as botas que me deram para a manipulação de tintas/velaturas, vernizes e tapa poros são as mais adequadas (8b); as botas têm o tamanho adequado (8c); quando as botas estão estragadas substituo-as imediatamente (8d); quando preciso tenho sempre disponível umas botas de substituição (8e); uso sempre botas (8f)

Os trabalhadores, 42,1 \% consideraram "não aplicável", a afirmação se Ihe deram botas de proteção para a manipulação de tintas/velaturas, vernizes e tapa poros (grupo 8 alínea a) do questionário), 22,1 \% "concorda", 9,3\% "concorda totalmente", 9,3 \% "discorda", 7,9 \% "discorda totalmente", 6,4 \% "sem opinião" e 2,9 \% "nem concorda, nem discorda". O teste Mann Whitney, revelou que não existem diferenças significativas, entre os diferentes tipos de produção $(p=0,070 ; \alpha=0,05)$, entre as faixas etárias $(p=0,310 ; \alpha=0,05)$ e entre as habilitações literárias $(p=0,656 ; \alpha=0,05)$. No entanto, revelou que existem 
diferenças significativas entre as empresas $(p \leq 0,05)$ e entre os sexos $(p \leq 0,05)$ (Anexo 7.6 - Tabela 79).

Em relação à opinião se as botas que lhes deram são as mais adequadas (grupo 8 alínea b) do questionário), 43,6\% refere "não aplicável", 20,7 \% "concorda", 10,7 \% "sem opinião", 8,6 \% "concorda totalmente", 6,4 \% "discorda", $5,7 \%$ "discorda totalmente" e $4,3 \%$ "nem concorda, nem discorda". O teste Mann Whitney, revelou que não existem diferenças significativas, entre os diferentes tipos de produção $(p=0,151 ; \alpha=0,05)$ e entre as habilitações literárias $(p=0,143 ; \alpha=0,05)$. No entanto, revelou que existem diferenças significativas entre as empresas $(p \leq 0,05)$, entre as faixas etárias $(p \leq 0,05)$ e entre os sexos $(p \leq 0,05)$ (Anexo $7.6-$ Tabela 80).

Se as botas de proteção têm o tamanho adequado (grupo 8 alínea c) do questionário), 43,2 \% considera "não aplicável", 23,0 \% "concorda", 11,5\% "concorda totalmente", 7,9 \% "sem opinião", 5,0 \% "discorda totalmente", 5,0 \% "discorda" e 4,3 \% "nem concorda, nem discorda". O teste Mann Whitney, revelou que não existem diferenças significativas, entre as faixas etárias $(p=0,177 ; \alpha=0,05)$, entre os diferentes tipos de produção $(p=0,341 ; \alpha=0,05)$ e entre as habilitações literárias $(p=0,227 ; \alpha=0,05)$. No entanto, revelou que existem diferenças significativas entre as empresas $(p \leq 0,05)$ e entre os sexos $(p \leq 0,05)$ (Anexo 7.6 - Tabela 81).

Quando as botas estão danificadas, 42,9 \% considera "não aplicável", 18,6 \% "concorda" que o substitui imediatamente (grupo 8 alínea d) do questionário), 10,7 \% "sem opinião", 10,7 \% "concorda totalmente", 7,1 \% "discorda", 5,0 \% "discorda totalmente" e 5,0 \% "nem concorda, nem discorda". O teste Mann Whitney, revelou que não existem diferenças significativas, entre as faixas etárias ( $p=0,395 ; \alpha=0,05)$, entre os diferentes tipos de produção ( $p=0,327$; $\alpha=0,05)$ e entre as habilitações literárias $(p=0,056 ; \alpha=0,05)$. No entanto, revelou que existem diferenças significativas entre as empresas $(p \leq 0,05)$ e entre os sexos $(p \leq 0,05)$ (Anexo $7.6-$ Tabela 82 ).

Se existem botas de substituição (grupo 8 alínea e) do questionário), 42,9 \% considera "não aplicável", 16,4 \% "concorda", 10,7 \% "concorda totalmente", 
10,7 \% "sem opinião", 8,6 \% "discorda", 5,7 \% "nem concorda, nem discorda" e $5,0 \%$ "discorda totalmente". O teste Mann Whitney, revelou que não existem diferenças significativas, entre as faixas etárias $(p=0,478 ; \alpha=0,05)$, entre os diferentes tipos de produção $(p=0,599 ; \alpha=0,05)$ e entre as habilitações literárias $(p=0,543 ; \alpha=0,05)$. No entanto, revelou que existem diferenças significativas entre as empresas $(p \leq 0,05)$ e entre os sexos $(p \leq 0,05)$ (Anexo 7.6 - Tabela 83).

Para 43,6 \% considera "não aplicável", usar sempre as botas (grupo 8 alínea f) do questionário), 19,3 \% "concorda", 13,6 \% "concorda totalmente", 8,6 \% "sem opinião", 5,7 \% “discorda", 5,0 \% "nem concorda, nem discorda" e 4,3 \% "discorda totalmente". O teste Mann Whitney, revelou que não existem diferenças significativas, entre os diferentes tipos de produção $(p=0,306 ; \alpha=0,05)$ e entre as habilitações literárias $(p=0,322 ; \alpha=0,05)$. No entanto, revelou que existem diferenças significativas entre as empresas $(p \leq 0,05)$, entre as faixas etárias $(p \leq 0,05)$ e entre os sexos ( $p \leq 0,05)$ (Anexo 7.6 - Tabela 84). 


\subsubsection{Utilização de Equipamentos de Proteção Coletiva}

Relativamente à utilização dos equipamentos de proteção coletiva, que nestes tipos de aplicações se centra na utilização de cabines de aspiração com ou sem cortina de água ou utilização de máquinas automáticas com aspiração integrada.

A média das respostas centra-se entre o "discordo totalmente" e o "discordo" para as afirmações em que não é necessário o funcionamento das cabines desde que utilize a máscara de proteção respiratória para gases, não é necessário o funcionamento dos equipamentos de extração desde que utilize a máscara de proteção respiratória para gases, no inverno às vezes não ligo as cabines e quando está frio não ligo os equipamentos de extração. Em relação à afirmação, ligo sempre as cabines quando aplico as tintas/velaturas, vernizes e tapa poros, a média das respostas centra-se entre o "discordo" e o "nem concordo, nem discordo" (Figura 24). 


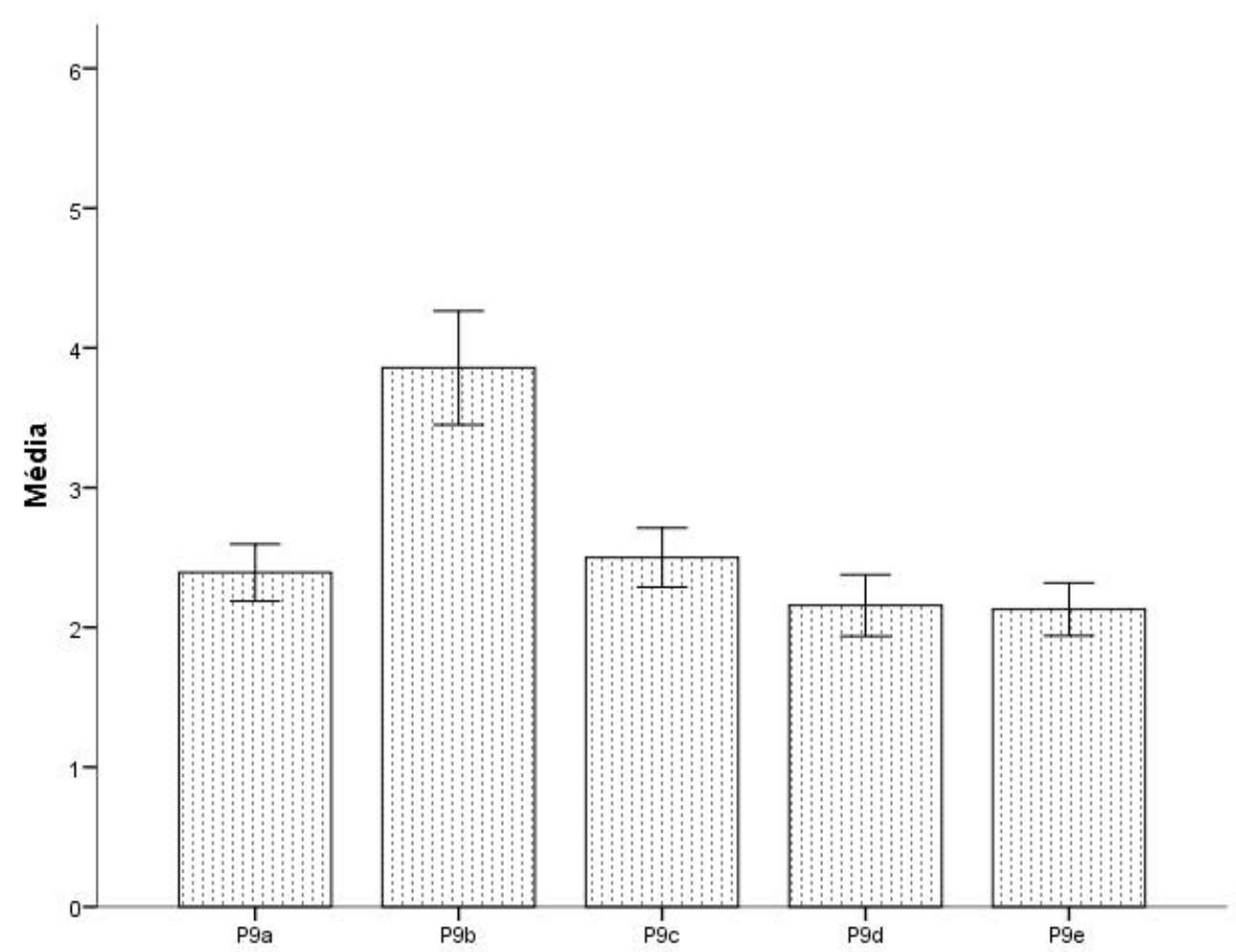

Figura 24 - Média das respostas (0 - não aplicável; 1 - sem opinião; 2 - discordo totalmente; 3 - discordo; 4 - nem concordo, nem discordo; 5 - concordo; 6 - concordo totalmente) sobre a Utilização de Equipamentos de Proteção Coletiva: não é necessário o funcionamento das cabines desde que utilize a máscara de proteção respiratória para gases (9a); ligo sempre as cabines quando aplico as tintas/velaturas, vernizes e tapa poros (9b); não é necessário o funcionamento dos equipamentos de extração desde que utilize a máscara de proteção respiratória para gases (9c); no inverno às vezes não ligo as cabines (9d); quando está frio não ligo os equipamentos de extração (9e)

Precisamente 43,6 \% "discorda", não é necessário o funcionamento das cabines desde que utilize a máscara de proteção respiratória para gases (grupo 9 alínea a) do questionário), 33,6 \% "discorda totalmente", 12,1\% considera "não aplicável", 5,7 \% "concorda", 2,8 \% "sem opinião", 1,4 \% "nem concorda, nem discorda" e $0,7 \%$ "concorda totalmente". O teste Mann Whitney, revelou que não existem diferenças significativas, entre as empresas $(p=0,960 ; \alpha=0,05)$, entre as faixas etárias $(p=0,639 ; \alpha=0,05)$ e entre as habilitações literárias $(p=0,207$; $\alpha=0,05)$. No entanto, revelou que existem diferenças significativas entre os 
diferentes tipos de produção $(p \leq 0,05)$ e entre os sexos $(p \leq 0,05)$ (Anexo 7.7 Tabela 85).

Quanto ao facto de ligarem sempre as cabines quando aplicam as tintas/velaturas, vernizes e tapa poros (grupo 9 alínea b) do questionário), 43,6 \% "concorda", 27,1 \% "concorda totalmente", 25,7 \% considera "não aplicável", 2,9 \% "sem opinião" e 0,7 \% "discorda". O teste Mann Whitney, revelou que não existem diferenças significativas, entre as empresas ( $p=0,569 ; \alpha=0,05)$, entre as faixas etárias $(p=0,538 ; \alpha=0,05)$ e entre as habilitações literárias $(p=0,706$; $\alpha=0,05$ ). No entanto, revelou que existem diferenças significativas entre os diferentes tipos de produção $(p \leq 0,05)$ e entre os sexos $(p \leq 0,05)$ (Anexo $7.7-$ Tabela 86).

Em relação a não ser necessário o funcionamento dos equipamentos de extração desde que utilize a máscara de proteção respiratória para gases (grupo 9 alínea c) do questionário), 41,4\% "discorda", 37,1\% "discorda totalmente", 9,3 \% considera "não aplicável", 4,3 \% "concorda totalmente", 2,9 \% "concorda", 2,9 \% "sem opinião" e 2,1 \% "nem concorda, nem discorda". O teste Mann Whitney, revelou que não existem diferenças significativas, entre as empresas $(p=0,970$; $\alpha=0,05)$, entre as faixas etárias $(p=0,372 ; \alpha=0,05)$ e entre as habilitações literárias $(p=0,729 ; \alpha=0,05)$. No entanto, revelou que existem diferenças significativas entre os diferentes tipos de produção $(p \leq 0,05)$ e entre os sexos $(p$ $\leq 0,05)$ (Anexo 7.7 - Tabela 87).

Se no Inverno às vezes não ligam as cabines (grupo 9 alínea d) do questionário), 36,4 \% "discorda", 35,7 \% "discorda totalmente", 18,6 \% considera "não aplicável", 3,6 \% "concorda", 2,9 \% "sem opinião", 1,4 \% "concorda totalmente" e 1,4 \% "nem concorda, nem discorda". O teste Mann Whitney, revelou que não existem diferenças significativas, entre as empresas $(p=0,832$; $\alpha=0,05)$, entre as faixas etárias $(p=0,894 ; \alpha=0,05)$ e entre as habilitações literárias $(p=0,750 ; \alpha=0,05)$. No entanto, revelou que existem diferenças significativas entre os diferentes tipos de produção $(p \leq 0,05)$ e entre os sexos ( $p$ $\leq 0,05$ ) (Anexo 7.7 - Tabela 88). 


\section{Resultados}

Dos inquiridos, 43,2 \% "discorda" que quando está frio não liga os equipamentos de extração (grupo 9 alínea e) do questionário), 36,0 \% "discorda totalmente", 15,8 \% considera "não aplicável", 3,6 \% "sem opinião", 0,7 \% "concorda" e $0,7 \%$ "concorda totalmente". O teste Mann Whitney, revelou que não existem diferenças significativas, entre as empresas ( $p=0,633 ; \alpha=0,05)$, entre as faixas etárias $(p=0,925 ; \alpha=0,05)$ e entre as habilitações literárias $(p=0,707 ; \alpha=0,05)$. No entanto, revelou que existem diferenças significativas entre os diferentes tipos de produção $(p \leq 0,05)$ e entre os sexos $(p \leq 0,05)$ (Anexo 7.7 - Tabela 89). 


\subsubsection{Efeitos Fisiológicos Subsequentes à Exposição a Tintas/Velaturas, Vernizes e Tapa Poros}

Nesta seção, apresenta-se a perceção dos trabalhadores sobre a sintomatologia associada à exposição às tintas/velaturas, vernizes e tapa poros.

A média das opiniões dos trabalhadores referentes aos efeitos da exposição às tintas/velaturas, vernizes e tapa poros, encontram-se sumariados na figura seguinte.

Estes referem entre o "discordo" e o "nem concordo, nem discordo" que a exposição às tintas/velaturas, vernizes e tapa poros the provoca irritação no nariz e garganta, irritação dos olhos, dores de cabeça e que quando não utilizam luvas na utilização de tintas/velaturas, vernizes e tapa poros ficam com a pele seca e irritada.

Indicam entre o "discordo totalmente" e o "discordo" que têm frequentemente dores de cabeça, antes de trabalhar na empresa de mobiliário não tinha dores de cabeça, a exposição às tintas/velaturas, vernizes e tapa poros causa sonolência, quando estão expostos às tintas/velaturas, vernizes e tapa poros perdem o apetite, desde que trabalham com as tintas/velaturas, vernizes e tapa poros têm maior dificuldade em ouvir, por vezes têm vómitos no trabalho, já tiveram vertigens/tonturas no posto de trabalho e que a perceção/sensibilidade aos cheiros diminuiu desde que ficaram expostos às tintas/velaturas, vernizes e tapa poros (Figura 25). 


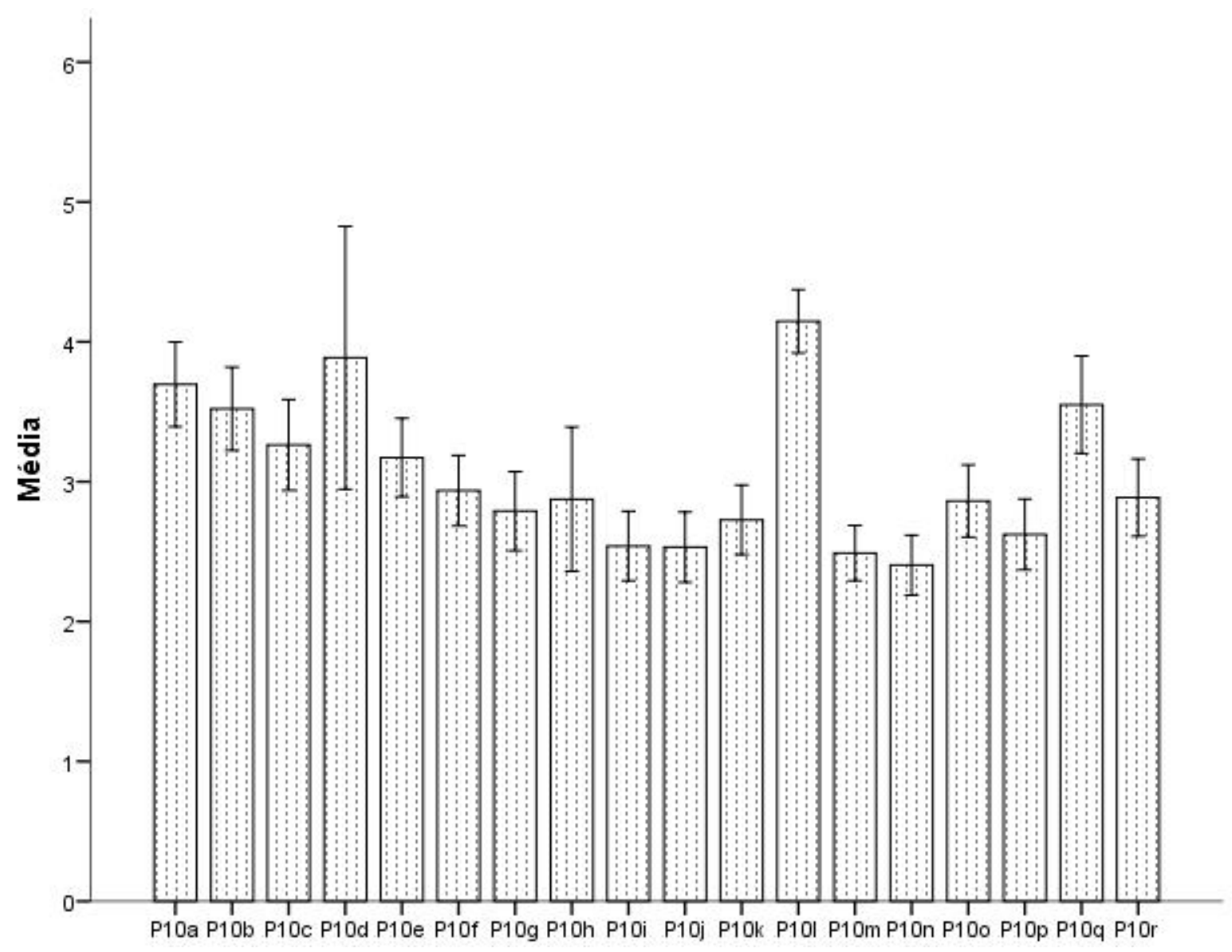

Figura 25 - Média das respostas (0 - não aplicável; 1 - sem opinião; 2 - discordo totalmente; 3 - discordo; 4 - nem concordo, nem discordo; 5 - concordo; 6 - concordo totalmente) sobre os Efeitos Fisiológicos Subsequentes à Exposição a Tintas/Velaturas, Vernizes e Tapa Poros: a exposição às tintas/velaturas, vernizes e tapa poros provoca-me irritação no nariz e garganta (10a); a exposição às tintas/velaturas, vernizes e tapa poros provoca-me irritação dos olhos (10b); durante o trabalho com as tintas/velaturas, vernizes e tapa poros já tive irritação dos olhos (10c); durante o trabalho com as tintas/velaturas, vernizes e tapa poros já tive irritação no nariz e garganta (10d); a exposição às tintas/velaturas, vernizes e tapa poros provoca-me dores de cabeça (10e); tenho frequentemente dores de cabeça (10f); antes de trabalhar na empresa de mobiliário não tinha dores de cabeça $(10 \mathrm{~g})$; antes de trabalhar na empresa de mobiliário tinha menos dores de cabeça (10h); a exposição às tintas/velaturas, vernizes e tapa poros causa-me sonolência (10i); quando estou exposto às tintas/velaturas, vernizes e tapa poros perco o apetite (10j); desde que trabalho com as tintas/velaturas, vernizes e tapa poros tenho maior dificuldade em ouvir (10k); por vezes tenho vómitos no trabalho $(10 \mathrm{~m})$; a exposição às tintas/velaturas, vernizes e tapa poros causa-me vómitos (10n); já tive vertigens/tonturas no meu posto de trabalho (10o); a exposição às tintas/velaturas, vernizes e tapa poros causa-me vertigens/tonturas (10p); quando não utilizo luvas e estou a utilizar as tintas/velaturas, vernizes e tapa poros fico com a pele seca e irritada (10q); a minha perceção/sensibilidade aos cheiros diminuiu desde que fiquei exposto às tintas/velaturas, vernizes e tapa poros (10r) 
Analisando as respostas, $31,2 \%$ "concorda" que a exposição às tintas/velaturas, vernizes e tapa poros provoca irritação no nariz e garganta (grupo 10 alínea a) do questionário), 27,7 \% "discorda", 13,5\% "concorda totalmente", 11,3 \% considera "não aplicável", 10,6 \% "nem concorda, nem discorda", 4,3 \% "sem opinião" e 1,4\% "discorda totalmente". O teste Mann Whitney, revelou que não existem diferenças significativas, entre as faixas etárias $(p=0,722 ; \alpha=0,05)$ e entre as habilitações literárias $(p=0,194 ; \alpha=0,05)$. No entanto, revelou que existem diferenças significativas entre as empresas $(p \leq$ $0,05)$, entre os diferentes tipos de produção $(p \leq 0,05)$ e entre os sexos $(p \leq 0,05)$ (Anexo 7.8 - Tabela 90).

Aproximadamente 30,7 \% "discorda", que a exposição às tintas/velaturas, vernizes e tapa poros provoca irritação nos olhos (grupo 10 alínea b) do questionário), 24,3\% "concorda", 15,7\% "nem concorda, nem discorda", 12,1\% considera "não aplicável", 11,4 \% "concorda totalmente", 4,3 \% "sem opinião" e $1,4 \%$ "discorda totalmente". O teste Mann Whitney, revelou que não existem diferenças significativas, entre as empresas $(p=0,058 ; \alpha=0,05)$, entre os diferentes tipos de produção $(p=0,121 ; \alpha=0,05)$, entre as faixas etárias $(p=0,885$; $\alpha=0,05)$, entre as habilitações literárias $(p=0,070 ; \alpha=0,05)$ e entre os sexos $(p=0,742 ; \alpha=0,05)$ (Anexo 7.8 - Tabela 91).

Segundo os inquiridos 28,4 \% "discorda", que a tiveram irritação nos olhos com a exposição às tintas/velaturas, vernizes e tapa poros (grupo 10 alínea c) do questionário), 25,5\% "concorda", 15,6 \% considera "não aplicável", 10,6 \% "concorda totalmente", 9,2 \% "nem concorda, nem discorda", $8,5 \%$ "sem opinião" e 2,1 \% "discorda totalmente". O teste Mann Whitney, revelou que não existem diferenças significativas, entre as empresas ( $p=0,442 ; \alpha=0,05)$, entre os sexos $(p=0,098 ; \alpha=0,05)$, entre as faixas etárias $(p=0,867 ; \alpha=0,05)$ e entre as habilitações literárias $(p=0,275 ; \alpha=0,05)$. No entanto, revelou que existem diferenças significativas entre os diferentes tipos de produção $(p \leq 0,05)$ (Anexo 7.8 - Tabela 92). 
Já se durante o trabalho tiveram irritação no nariz e garganta com a exposição às tintas/velaturas, vernizes e tapa poros (grupo 10 alínea d) do questionário), 35,0 \% "concorda", 27,9 \% "discorda", 15,7 \% considera "não aplicável", 10,0 \% "concorda totalmente", 4,3 \% "nem concorda, nem discorda", 4,3 \% "sem opinião" e 2,8 \% "discorda totalmente". O teste Mann Whitney, revelou que não existem diferenças significativas, entre as empresas ( $p=0,613$; $\alpha=0,05)$, entre as faixas etárias $(p=0,594 ; \alpha=0,05)$ e entre as habilitações literárias $(p=0,068 ; \alpha=0,05)$. No entanto, revelou que existem diferenças significativas entre os diferentes tipos de produção $(p \leq 0,05)$ e entre os sexos ( $p$ $\leq 0,05)$ (Anexo 7.8 - Tabela 93).

Quanto ao facto a exposição às tintas/velaturas, vernizes e tapa poros Ihes provocar dores de cabeça (grupo 10 alínea e) do questionário), 30,2 \% "discorda", 21,6 \% "concorda", 18,0 \% "nem concorda, nem discorda", 12,2 \% "sem opinião", 9,4 \% considera "não aplicável", 4,3 \% "concorda totalmente" e 4,3 \% "discorda totalmente". O teste Mann Whitney, revelou que não existem diferenças significativas, entre as empresas $(p=0,081 ; \alpha=0,05)$ e entre as habilitações literárias $(p=0,087 ; \alpha=0,05)$. No entanto, revelou que existem diferenças significativas entre os diferentes tipos de produção $(p \leq 0,05)$, entre as faixas etárias $(p \leq 0,05)$ e entre os sexos $(p \leq 0,05)$ (Anexo 7.8 - Tabela 94).

Se têm frequentemente dores de cabeça (grupo 10 alínea f) do questionário), 43,6 \% "discorda", 14,3\% "nem concorda, nem discorda", 12,1\% "concorda", 12,1 \% "sem opinião", 8,5 \% considera "não aplicável", 5,7 \% "discorda totalmente" e 3,6 \% "concorda totalmente". O teste Mann Whitney, revelou que não existem diferenças significativas, entre as empresas $(p=0,735$; $\alpha=0,05)$, entre os diferentes tipos de produção $(p=0,120 ; \alpha=0,05)$ e entre as habilitações literárias $(p=0,087 ; \alpha=0,05)$. No entanto, revelou que existem diferenças significativas entre as faixas etárias $(p \leq 0,05)$ e entre os sexos $(p \leq$ 0,05) (Anexo 7.8 - Tabela 95).

E se antes de trabalhar na empresa de mobiliário não tinham dores de cabeça (grupo 10 alínea g) do questionário), 37,0 \% "discorda", 15,9 \% "sem opinião", 13,8 \% "nem concorda, nem discorda", 12,3 \% considera "não aplicável", 11,6 \% "concorda", 5,1 \% "concorda totalmente" e 4,3\% "discorda 
totalmente". O teste Mann Whitney, revelou que não existem diferenças significativas, entre os diferentes tipos de produção $(p=0,116 ; \alpha=0,05)$, entre as faixas etárias $(p=0,111 ; \alpha=0,05)$ e entre as habilitações literárias $(p=0,097$; $\alpha=0,05)$. No entanto, revelou que existem diferenças significativas entre as empresas $(p \leq 0,05)$ e entre os sexos $(p \leq 0,05)$ (Anexo 7.8 - Tabela 96).

Se tinham menos dores de cabeça antes de entrar na empresa (grupo 10 alínea h) do questionário), 36,8 \% "discorda", 16,2 \% "sem opinião", 12,4 \% "nem concorda, nem discorda", 11,8 \% considera "não aplicável", 10,3 \% "concorda", 9,6 \% "discorda totalmente" e 2,9\% "concorda totalmente". O teste Mann Whitney, revelou que não existem diferenças significativas, entre os diferentes tipos de produção $(p=0,661 ; \alpha=0,05)$, entre as faixas etárias $(p=0,454 ; \alpha=0,05)$ e entre as habilitações literárias $(p=0,131 ; \alpha=0,05)$. No entanto, revelou que existem diferenças significativas entre as empresas $(p \leq 0,05)$ e entre os sexos $(p \leq 0,05)$ (Anexo 7.8 - Tabela 97).

Os inquiridos discordam (40,3 \%) quanto à afirmação "a exposição às tintas/velaturas, vernizes e tapa poros causa-me sonolência" (grupo 10 alínea i) do questionário); 16,5 \% "sem opinião"; 12,9 \% "nem concorda, nem discorda"; 12,2 \% "não aplicável"; 8,6 \% "discorda totalmente"; 8,6 \% "concorda"; 0,7 \% "concorda totalmente". O teste Mann Whitney, revelou que não existem diferenças significativas, entre as empresas $(p=0,461 ; \alpha=0,05)$, entre os sexos $(p=0,071 ; \alpha=0,05)$, entre as faixas etárias $(p=0,103 ; \alpha=0,05)$ e entre as habilitações literárias $(p=0,066 ; \alpha=0,05)$. No entanto, revelou que existem diferenças significativas entre os diferentes tipos de produção $(p \leq 0,05)$ (Anexo 7.8 - Tabela 98).

Para a afirmação "quando exposto às tintas/velaturas, vernizes e tapa poros perco o apetite" (grupo 10 alínea j) do questionário), 46,0 \% "discorda", 13,7 \% "sem opinião", 13,7 \% considera "não aplicável", 8,6 \% "discorda totalmente", 7,9 \% "nem concorda, nem discorda", 7,9 \% "concorda" e 2,2 \% "concorda totalmente". O teste Mann Whitney, revelou que não existem diferenças significativas, entre as empresas $(p=0,808 ; \alpha=0,05)$ e entre as faixas etárias $(p=0,793 ; \alpha=0,05)$. No entanto, revelou que existem diferenças significativas entre os diferentes tipos de produção $(p \leq 0,05)$, entre as 
habilitações literárias $(p \leq 0,05)$ e entre os sexos $(p \leq 0,05)$ (Anexo 7.8 - Tabela 99).

Quanto ao facto de terem maior dificuldade em ouvir desde que trabalham com as tintas/velaturas, vernizes e tapa poros (grupo 10 alínea k) do questionário), 44,6 \% "discorda", 12,2 \% "sem opinião", 11,5% "nem concorda, nem discorda", 10,8 \% considera "não aplicável", 10,1 \% "concorda", 8,6 \% "discorda totalmente" e 2,2 \% "concorda totalmente". O teste Mann Whitney, revelou que não existem diferenças significativas, entre as empresas $(p=0,071$; $\alpha=0,05)$, entre os sexos $(p=0,764 ; \alpha=0,05)$, entre as habilitações literárias $(p=0,672 ; \alpha=0,05)$ e entre as faixas etárias $(p=0,648 ; \alpha=0,05)$. No entanto, revelou que existem diferenças significativas entre os diferentes tipos de produção ( $p \leq 0,05)$ (Anexo 7.8 - Tabela 100).

Se há muito ruído no posto de trabalho (grupo 10 alínea I) do questionário), 38,2 \% "concorda", 22,8 \% "discorda", 20,6 \% "nem concorda, nem discorda", 11,0 \% "concorda totalmente", 3,7 \% "sem opinião", 2,2 \% considera "não aplicável" e 1,5 \% "discorda totalmente". O teste Mann Whitney, revelou que não existem diferenças significativas, entre os diferentes tipos de produção $(p=0,457 ; \alpha=0,05)$, entre os sexos $(p=0,332 ; \alpha=0,05)$ e entre as habilitações literárias $(p=0,302 ; \alpha=0,05)$. No entanto, revelou que existem diferenças significativas entre as empresas $(p \leq 0,05)$ e entre as faixas etárias $(p \leq 0,05)$ (Anexo 7.8 - Tabela 101).

A maioria dos trabalhadores $(55,4 \%)$ "discorda" que por vezes têm vómitos no posto de trabalho (grupo 10 alínea $\mathrm{m}$ ) do questionário), 16,6 \% "discorda totalmente", 12,2 \% "sem opinião", 7,9 \% considera "não aplicável", 4,3 \% "concorda", 2,8 \% "nem concorda, nem discorda" e 0,7 \% "concorda totalmente". O teste Mann Whitney, revelou que não existem diferenças significativas, entre as empresas $(p=0,664 ; \alpha=0,05)$, entre os sexos $(p=0,426$; $\alpha=0,05)$, entre as faixas etárias $(p=0,975 ; \alpha=0,05)$ e entre as habilitações literárias $(p=0,237 ; \alpha=0,05)$. No entanto, revelou que existem diferenças significativas entre os diferentes tipos de produção $(p \leq 0,05)$ (Anexo 7.8 Tabela 102). 
Se a exposição às tintas/velaturas, vernizes e tapa poros causa vómitos (grupo 10 alínea n) do questionário), 52,5 \% "discorda", 15,1 \% "sem opinião", 14,4 \% "discorda totalmente", 10,1 \% considera "não aplicável", 4,3 \% "concorda", 2,2 \% "nem concorda, nem discorda" e 1,4 \% "concorda totalmente". $\mathrm{O}$ teste Mann Whitney, revelou que não existem diferenças significativas, entre as empresas ( $p=0,475 ; \alpha=0,05)$, entre os sexos $(p=0,616 ; \alpha=0,05)$, entre as faixas etárias $(p=0,958 ; \alpha=0,05)$ e entre as habilitações literárias $(p=0,184$; $\alpha=0,05)$. No entanto, revelou que existem diferenças significativas entre os diferentes tipos de produção $(p \leq 0,05)$ (Anexo 7.8 - Tabela 103).

Os dados facultados indicam que $43,1 \%$ dos trabalhadores inquiridos "discorda" que já teve vertigens/tonturas no posto de trabalho (grupo 10 alínea o) do questionário), 14,6 \% "concorda", 13,1\% "discorda totalmente", 9,5\% "sem opinião", 9,5 \% "não aplicável", 6,6 \% "nem concorda, nem discorda" e 3,5\% "concorda totalmente". O teste Mann Whitney, revelou que não existem diferenças significativas, entre os diferentes tipos de produção $(p=0,259$; $\alpha=0,05)$, entre os sexos $(p=0,950 ; \alpha=0,05)$, entre as faixas etárias $(p=0,851$; $\alpha=0,05)$ e entre as habilitações literárias $(p=0,177 ; \alpha=0,05)$. No entanto, revelou que existem diferenças significativas entre as empresas $(p \leq 0,05)$ (Anexo $7.8-$ Tabela 104).

Precisamente $43,5 \%$ dos trabalhadores inquiridos "discorda" que a exposição às tintas/velaturas, vernizes e tapa poros the cause vertigens/tonturas (grupo 10 alínea p) do questionário), 13,0 \% "discorda totalmente", 13,0 \% "não aplicável", 10,1 \% "concorda", 10,1 \% "sem opinião", 8,0 \% "nem concorda, nem discorda" e 2,2 \% "concorda totalmente". O teste Mann Whitney, revelou que não existem diferenças significativas, entre as empresas ( $p=0,067 ; \alpha=0,05)$, entre os sexos $(p=0,146 ; \alpha=0,05)$, entre as faixas etárias $(p=0,991 ; \alpha=0,05)$ e entre as habilitações literárias $(p=0,438 ; \alpha=0,05)$. No entanto, revelou que existem diferenças significativas entre os diferentes tipos de produção $(p \leq 0,05)$ (Anexo 7.8 - Tabela 105).

Relativamente à afirmação "quando não utilizo luvas e estou a utilizar as tintas/velaturas, vernizes e tapa poros fico com a pele seca e irritada" (grupo 10 alínea q) do questionário), 39,3 \% "concorda", 16,4 \% "não aplicável", 13,6 \% 
"discorda", 12,9 \% "concorda totalmente", 7,9 \% "sem opinião", 6,4 \% "nem concorda, nem discorda" e 3,6 \% "discorda totalmente". O teste Mann Whitney, revelou que não existem diferenças significativas, entre as empresas $(p=0,055$; $\alpha=0,05)$, entre os sexos $(p=0,042 ; \alpha=0,05)$, entre as faixas etárias $(p=0,386$; $\alpha=0,05)$ e entre as habilitações literárias $(p=0,002 ; \alpha=0,05)$. No entanto, revelou que existem diferenças significativas entre os diferentes tipos de produção ( $p \leq$ 0,05) (Anexo 7.8 - Tabela 106).

Segundo os inquiridos 36,2 \% "discorda" com a afirmação "a minha perceção/sensibilidade aos cheiros diminuiu desde que fiquei exposto às tintas/velaturas, vernizes e tapa poros" (grupo 10 alínea r) do questionário), 16,3 \% "nem concorda, nem discorda", 12,8 \% "sem opinião", 11,3 \% "não aplicável", 9,9 \% "concorda", 7,1 \% "discorda totalmente" e 6,4 \% "concorda totalmente". 0 teste Mann Whitney, revelou que não existem diferenças significativas, entre as faixas etárias $(p=0,430 ; \alpha=0,05)$ e entre as habilitações literárias $(p=0,631$; $\alpha=0,05)$. No entanto, revelou que existem diferenças significativas entre as empresas $(p \leq 0,05)$, entre os diferentes tipos de produção $(p \leq 0,05)$ e entre os sexos $(p \leq 0,05)$ (Anexo 7.8 - Tabela 107). 


\subsubsection{Interferência do Posto de Trabalho na Exposição}

Nesta seção analisar-se-á a estrutura dos postos de trabalho, forma como estão organizados e como estas caraterísticas influenciam a exposição às tintas/velaturas, vernizes e tapa poros".

Para as afirmações "ritmo de trabalho é muito intenso" e "estou satisfeito com o funcionamento das cabines de aspiração", a opinião dos inquiridos centrase entre "algumas vezes" e a "maioria das vezes". Para as afirmações, "por vezes noto muito cheiro aos produtos químicos", "acho que as cabines de aspiração têm a manutenção adequada", e "existe preocupação da empresa em diminuir a exposição às tintas/velaturas, vernizes e tapa poros", a média das respostas centra-se entre o "raramente" e o "algumas vezes". Quanto às afirmações, "às vezes os recipientes vazios das tintas/velaturas, vernizes e tapa poros não são retirados imediatamente dos postos de trabalho", "é possível diminuir a exposição às tintas/velaturas, vernizes e tapa poros" e "é possível diminuir a exposição aos cheiros das tintas/velaturas, vernizes e tapa poros", a média das respostas centra-se entre "nunca" e "raramente" (Figura 26). 


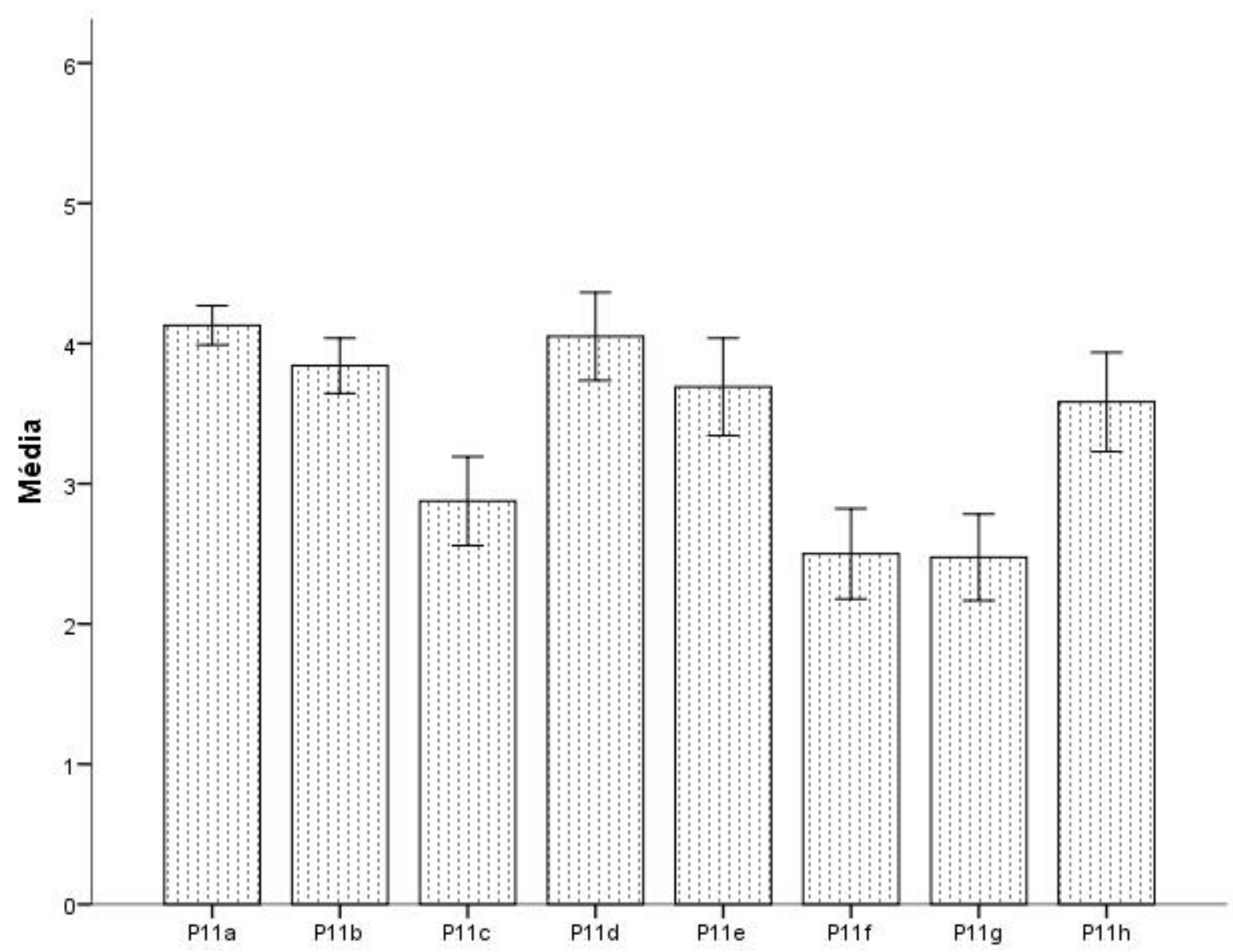

Figura 26 - Média das respostas (0 - não aplicável; 1 - sem opinião; 2 - nunca; 3 - raramente;

4 - algumas vezes; 5 - maioria das vezes; 6 - sempre) sobre a Interferência do Posto de Trabalho na Exposição às Tintas/Velaturas, Vernizes e Tapa Poros: ritmo de trabalho é muito intenso (11a); por vezes noto muito cheiro aos produtos químicos (11b); às vezes os recipientes vazios das tintas/velaturas, vernizes e tapa poros não são retirados imediatamente dos postos de trabalho (11c); estou satisfeito com o funcionamento das cabines de aspiração (11d); a acho que as cabines de aspiração têm a manutenção adequada (11e); é possível diminuir a exposição às tintas/velaturas, vernizes e tapa poros (11f); é possível diminuir a exposição aos cheiros das tintas/velaturas, vernizes e tapa poros (11g); existe preocupação da empresa em diminuir a exposição às tintas/velaturas, vernizes e tapa poros (11h);

A grande maioria dos inquiridos (67,0 \%) afirma que o ritmo de trabalho "algumas vezes" é muito intenso (grupo 11 alínea a) do questionário), 11,5 \% a "maioria das vezes", 11,6 \% "raramente", 8,5 \% "sempre" e 1,4 \% "sem opinião". O teste Mann Whitney, revelou que não existem diferenças significativas, entre os diferentes tipos de produção $(p=0,359 ; \alpha=0,05)$, entre os sexos $(p=0,201$; $\alpha=0,05)$, entre as faixas etárias $(p=0,437 ; \alpha=0,05)$ e entre as habilitações 
literárias $(p=0,763 ; \alpha=0,05)$. No entanto, revelou que existem diferenças significativas entre as empresas $(p \leq 0,05)$ (Anexo 7.9 - Tabela 108).

Se os trabalhadores notam muito os odores aos produtos químicos (grupo 11 alínea b) do questionário), 42,4 \% "algumas vezes", 26,6 \% "raramente", 13,7 \% a "maioria das vezes", 9,4 \% "sempre", 4,3 \% "sem opinião" e 0,7 \% "não aplicável". O teste Mann Whitney, revelou que não existem diferenças significativas, entre os diferentes tipos de produção $(p=0,496 ; \alpha=0,05)$, entre os sexos $(p=0,145 ; \alpha=0,05)$, entre as faixas etárias $(p=0,700 ; \alpha=0,05)$ e entre as habilitações literárias $(p=0,707 ; \alpha=0,05)$. No entanto, revelou que existem diferenças significativas entre as empresas $(p \leq 0,05)$ (Anexo 7.9 - Tabela 109).

Sensivelmente 22,6 \% dos inquiridos afirma que "raramente" que "às vezes os recipientes vazios das tintas/velaturas, vernizes e tapa poros não são retirados imediatamente dos postos de trabalho" (grupo 11 alínea c) do questionário), 17,5 \% "algumas vezes", 14,6 \% "sem opinião", 14,6 \% "não aplicável", 11,0 \% a "maioria das vezes", 10,2 \% "sempre" e 9,5\% "nunca". O teste Mann Whitney, revelou que não existem diferenças significativas, entre as habilitações literárias $(p=0,056 ; \alpha=0,05)$. No entanto, revelou que existem diferenças significativas entre as empresas $(p \leq 0,05)$, entre os diferentes tipos de produção $(p \leq 0,05)$, entre os sexos $(p \leq 0,05)$ e entre as faixas etárias $(p \leq$ $0,05)$ (Anexo 7.9 - Tabela 110).

Da amostra, 26,7 \% refere que está "sempre" satisfeito com o funcionamento das cabines de aspiração (grupo 11 alínea d) do questionário), 25,9 \% a "maioria das vezes", 17,3 \% "algumas vezes", 10,1 \% "sem opinião", 7,9 \% "raramente", 6,4 \% "nunca" e 5,7 \% "não aplicável". O teste Mann Whitney, revelou que não existem diferenças significativas, entre os diferentes tipos de produção $(p=0,187 ; \alpha=0,05)$, entre as habilitações literárias $(p=0,270 ; \alpha=0,05)$ e entre as faixas etárias $(p=0,540 ; \alpha=0,05)$. No entanto, revelou que existem diferenças significativas entre as empresas $(p \leq 0,05)$ e entre os sexos $(p \leq 0,05)$ (Anexo 7.9 - Tabela 111).

Quanto à manutenção das cabines, 25,2 \% refere têm "sempre" a manutenção adequada (grupo 11 alínea e) do questionário), 20,1 \% a "maioria 
das vezes", 15,9 \% "algumas vezes", 15,8 \% "sem opinião", 10,7 \% "raramente", 9,4 \% "não aplicável" e 2,8 \% "nunca". O teste Mann Whitney, revelou que não existem diferenças significativas, entre as habilitações literárias $(p=0,250$; $\alpha=0,05)$ e entre as faixas etárias ( $p=0,296 ; \alpha=0,05)$. No entanto, revelou que existem diferenças significativas entre as empresas $(p \leq 0,05)$, entre os diferentes tipos de produção $(p \leq 0,05)$ e entre os sexos $(p \leq 0,05)$ (Anexo $7.9-$ Tabela 112).

Verifica-se que $37,5 \%$ dos inquiridos refere "sem opinião" se é possível diminuir a exposição às tintas/velaturas, vernizes e tapa poros (grupo 11 alínea f) do questionário), 19,1 \% "algumas vezes", 10,3\% "não aplicável", 8,8 \% "sempre", 8,8 \% a "maioria das vezes", 8,1 \% "raramente" e 7,4 \% "nunca". O teste Mann Whitney, revelou que não existem diferenças significativas, entre os sexos $(p=0,277 ; \alpha=0,05)$ e entre as habilitações literárias $(p=0,197 ; \alpha=0,05)$. No entanto, revelou que existem diferenças significativas entre as empresas ( $p \leq$ $0,05)$, entre os diferentes tipos de produção $(p \leq 0,05)$ e entre as faixas etárias ( $p$ $\leq$ 0,05) (Anexo $7.9-$ Tabela 113).

Relativamente aos odores, 35,3\% dos inquiridos refere "sem opinião" se é possível diminuir a exposição (grupo 11 alínea g) do questionário), 18,0 \% "algumas vezes", 11,5 \% "raramente", 10,1 \% "não aplicável", 9,3 \% "nunca", 7,9 $\%$ "sempre" e 7,9 \% a "maioria das vezes". O teste Mann Whitney, revelou que não existem diferenças significativas, entre os sexos $(p=0,334 ; \alpha=0,05)$ e entre as habilitações literárias $(p=0,219 ; \alpha=0,05)$. No entanto, revelou que existem diferenças significativas entre as empresas $(p \leq 0,05)$, entre os diferentes tipos de produção $(p \leq 0,05)$ e entre as faixas etárias $(p \leq 0,05)$ (Anexo 7.9 - Tabela 114).

Quanto à preocupação da empresa em diminuir a exposição às tintas/velaturas, vernizes e tapa poros (grupo 11 alínea h) do questionário), 27,4 $\%$ dos inquiridos refere "sempre", 25,2 \% "sem opinião", 17,4 \% "algumas vezes", 14,3 \% a "maioria das vezes", 7,8 \% "raramente", 5,8 \% "não aplicável" e 2,1 \% "nunca". O teste Mann Whitney, revelou que não existem diferenças significativas, entre os diferentes tipos de produção $(p=0,156 ; \alpha=0,05)$, entre as faixas etárias $(p=0,641 ; \alpha=0,05)$, entre os sexos $(p=0,315 ; \alpha=0,05)$ e entre as 
habilitações literárias $(p=0,637 ; \alpha=0,05)$. No entanto, revelou que existem diferenças significativas entre as empresas $(p \leq 0,05)$ (Anexo 7.9 - Tabela 115).

\subsubsection{Frequência de Atitudes Preventivas}

Com esta série de afirmações pretende-se conhecer alguns comportamentos dos trabalhadores relativamente às suas atitudes preventivas.

A opinião dos inquiridos centra-se em média entre a "maiorias das vezes" e o "sempre", relativamente à execução das atividades de acordo com as instruções de trabalho e de acordo com a formação da empresa. Referem entre "algumas vezes" e a maioria das vezes" que usam sempre luvas na manipulação das tintas/velaturas, vernizes e tapa poros e que utilizam sempre a máscara de proteção na manipulação das tintas/velaturas, vernizes e tapa poros. E média indicam entre "raramente" e "algumas vezes" que não cumprem as regras de segurança. Afirmam entre o "nunca" e o "raramente" relativamente à utilização de avental e fato de proteção na manipulação das tintas/velaturas, vernizes e tapa poros (Figura 27). 


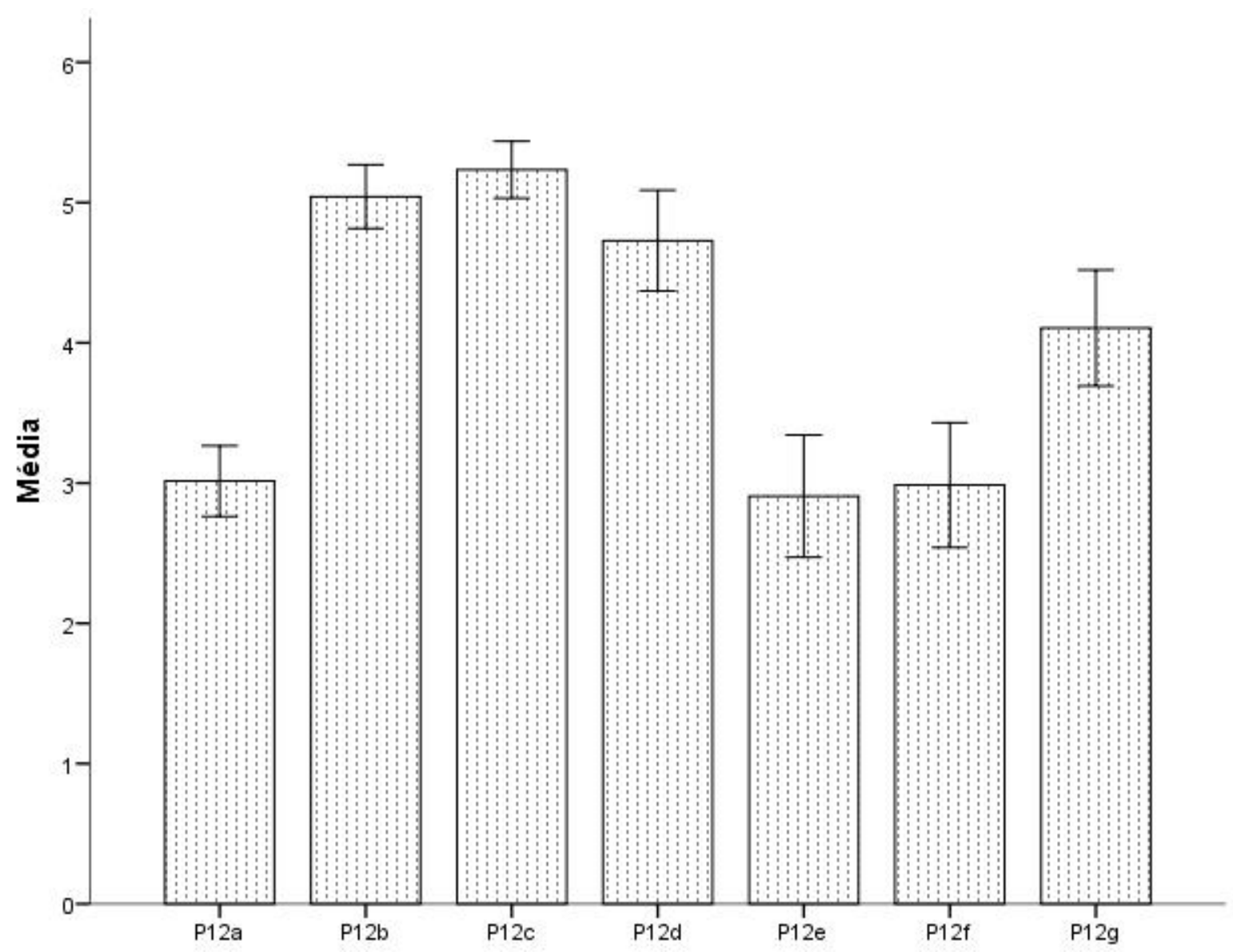

Figura 27 - Média das respostas (0 - não aplicável; 1 - sem opinião; 2 - nunca; 3 - raramente;

4 - algumas vezes; 5 - maioria das vezes; 6 - sempre) sobre a Frequência de Atitudes

Preventivas: não cumprir as regras de segurança (12a); executar as atividades de acordo com as instruções de trabalho (12b); executar as atividades de acordo com o que a empresa me ensinou (12c); usar sempre luvas na manipulação das tintas/velaturas, vernizes e tapa poros (12d); usar sempre avental na manipulação das tintas/velaturas, vernizes e tapa poros (12e); usar sempre fato de proteção na manipulação das tintas/velaturas, vernizes e tapa poros (12f); utilizar sempre a máscara de proteção na manipulação das tintas/velaturas, vernizes e tapa poros (12g);

Segundo os trabalhadores, $31,5 \%$ "nunca" ignora as regras de segurança (grupo 12 alínea a) do questionário), 24,2 \% "raramente", 15,7 \% "algumas vezes", 10,8 \% "sempre", 10,0 \% "sem opinião", 5,7 \% a "maioria das vezes" e $2,1 \%$ "não aplicável". O teste Mann Whitney, revelou que não existem diferenças significativas, entre os diferentes tipos de produção $(p=0,421$; $\alpha=0,05)$, entre as faixas etárias $(p=0,638 ; \alpha=0,05)$, entre os sexos $(p=0,875$; 
$\alpha=0,05)$ e entre as habilitações literárias $(p=0,072 ; \alpha=0,05)$. No entanto, revelou que existem diferenças significativas entre as empresas $(p \leq 0,05)$ (Anexo $7.10-$ Tabela 116).

A maioria dos trabalhadores, 50,8 \% refere que executa "sempre" as atividades de acordo com as instruções de trabalho (grupo 12 alínea b) do questionário), 26,8 \% a "maioria das vezes", 12,6 \% "algumas vezes", 7,0 \% "sem opinião", 2,8 \% "raramente". O teste Mann Whitney, revelou que não existem diferenças significativas, entre os diferentes tipos de produção $(p=0,671$; $\alpha=0,05)$, entre as faixas etárias $(p=0,770 ; \alpha=0,05)$, entre os sexos $(p=0,261$; $\alpha=0,05)$ e entre as habilitações literárias $(p=0,358 ; \alpha=0,05)$. No entanto, revelou que existem diferenças significativas entre as empresas $(p \leq 0,05)$ (Anexo $7.10-$ Tabela 117).

Também 56,7 \% refere que executa "sempre" as atividades de acordo com a formação da empresa (grupo 12 alínea c) do questionário), 27,0 \% a "maioria das vezes", 9,2 \% "algumas vezes", 5,0 \% "sem opinião", 2,1\% "raramente". O teste Mann Whitney, revelou que não existem diferenças significativas, entre as empresas $(p=0,082 ; \alpha=0,05)$, entre os diferentes tipos de produção ( $p=0,771 ; \alpha=0,05)$, entre as faixas etárias ( $p=0,817 ; \alpha=0,05)$, entre os sexos $(p=0,493 ; \alpha=0,05)$ e entre as habilitações literárias $(p=0,773 ; \alpha=0,05)$ (Anexo 7.10 - Tabela 118).

Dos trabalhadores inquiridos, 60,8 \% referem que usam "sempre" luvas na manipulação das tintas/velaturas, vernizes e tapa poros (grupo 12 alínea d) do questionário), 17,1 \% a "maioria das vezes", 14,4 " "não aplicável", 4,3 \% "algumas vezes", 2,1 \% "sem opinião", 0,7 \% "raramente" e 0,7 \% "nunca". O teste Mann Whitney, revelou que não existem diferenças significativas, entre as empresas $(p=0,260 ; \alpha=0,05)$, entre as faixas etárias $(p=0,785 ; \alpha=0,05)$ e entre as habilitações literárias $(p=0,930 ; \alpha=0,05)$. No entanto, revelou que existem diferenças significativas entre os diferentes tipos de produção $(p \leq 0,05)$ e entre os sexos $(p \leq 0,05)$ (Anexo 7.10 - Tabela 119).

Relativamente ao uso de avental, 32,9\% referem que usam "sempre" na manipulação das tintas/velaturas, vernizes e tapa poros (grupo 12 alínea e) do 
questionário), 32,9 “ "não aplicável”, 10,1 \% "sem opinião”, 8,5 \% "nunca”, 7,2 \% a "maioria das vezes", 4,9 \% "algumas vezes" e 3,5 \% "raramente". O teste Mann Whitney, revelou que não existem diferenças significativas, entre os diferentes tipos de produção $(p=0,080 ; \alpha=0,05)$, entre as faixas etárias $(p=0,327 ; \alpha=0,05)$ e entre as habilitações literárias $(p=0,788 ; \alpha=0,05)$. No entanto, revelou que existem diferenças significativas entre as empresas $(p \leq 0,05)$ e entre os sexos $(p \leq 0,05)$ (Anexo $7.10-$ Tabela 120).

A utilização de fato de proteção, 33,9 \% referem que usam "sempre" na manipulação das tintas/velaturas, vernizes e tapa poros (grupo 12 alínea f) do questionário), 33,1 \% "não aplicável", 10,8 \% "sem opinião", 10,1 \% a "maioria das vezes", 6,4 \% "nunca", 4,3\% "algumas vezes" e 1,4 \% "raramente". O teste Mann Whitney, revelou que não existem diferenças significativas, entre as faixas etárias $(p=0,371 ; \alpha=0,05)$ e entre as habilitações literárias $(p=0,079 ; \alpha=0,05)$. No entanto, revelou que existem diferenças significativas entre as empresas ( $p \leq$ $0,05)$, entre os diferentes tipos de produção $(p \leq 0,05)$ e entre os sexos $(p \leq 0,05)$ (Anexo 7.10 - Tabela 121).

A maioria dos inquiridos, 50,7 \% indica que usam "sempre" máscara na manipulação das tintas/velaturas, vernizes e tapa poros (grupo 12 alínea g) do questionário), 22,5 \% "não aplicável", 13,4 \% a "maioria das vezes", 8,5 \% "algumas vezes", 4,2 \% "sem opinião" e 0,7 \% "nunca". O teste Mann Whitney, revelou que não existem diferenças significativas, entre as empresas $(p=0,186$; $\alpha=0,05)$, entre as faixas etárias $(p=0,492 ; \alpha=0,05)$ e entre as habilitações literárias $(p=0,804 ; \alpha=0,05)$. No entanto, revelou que existem diferenças significativas entre os diferentes tipos de produção $(p \leq 0,05)$ e entre os sexos ( $p$ $\leq 0,05$ ) (Anexo 7.10 - Tabela 122). 


\subsubsection{Formação profissional prestada pelas empresas}

Um dos fatores cruciais ao comportamento preventivo por parte dos trabalhadores é a formação que as empresas prestam aos mesmos. Assim, com este conjunto de afirmações pretende-se conhecer o nível de formação dos trabalhadores em matérias de segurança e saúde no trabalho.

Nos gráficos seguintes analisar-se-á a formação no combate a incêndios, riscos, manuseamento, como proceder no caso de derrame e na aplicação dos produtos químicos e por fim, quando foi a última vez que os trabalhadores tiveram formação sobre riscos laborais no posto de trabalho.

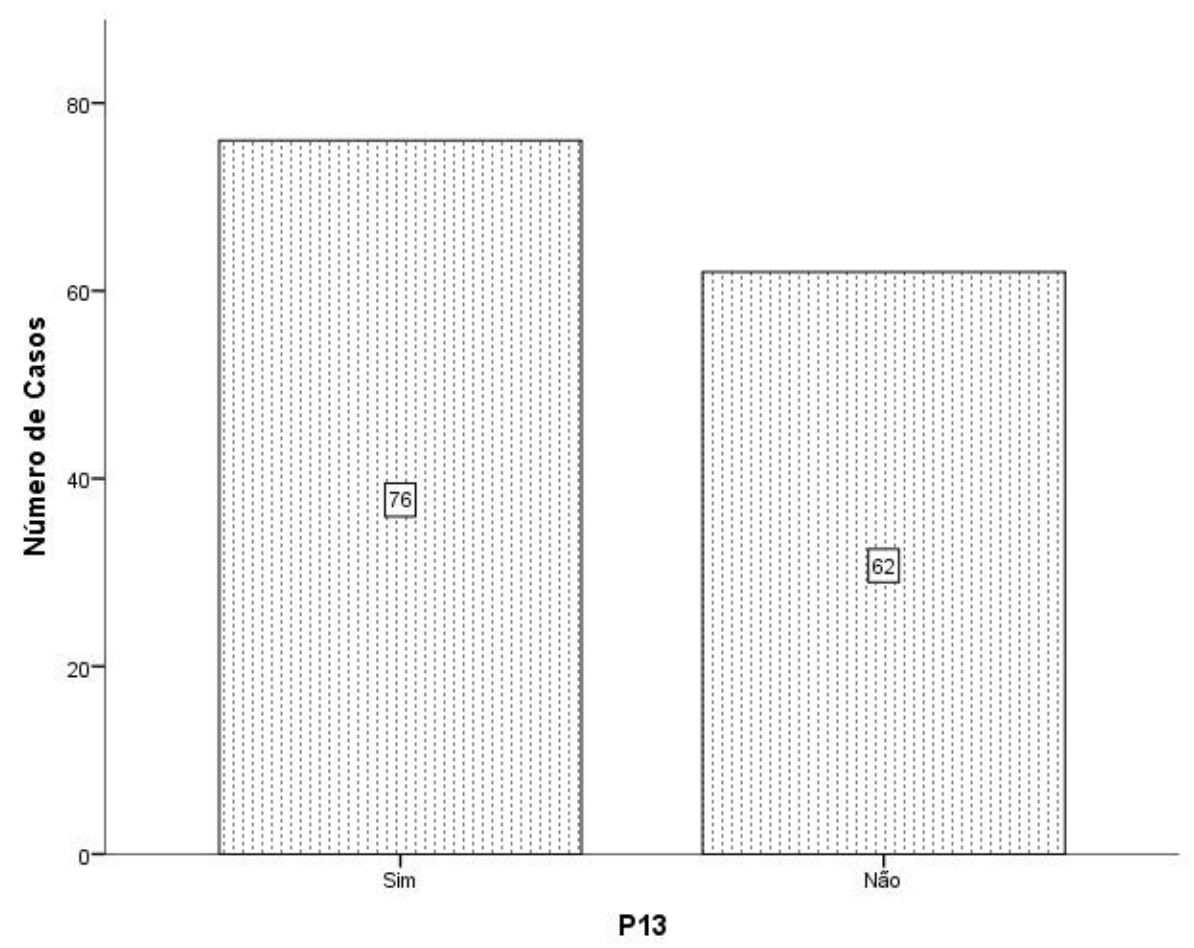

Figura 28 - Número de trabalhadores sobre a Formação em Combate a Incêndios 
Verifica-se que apesar da esmagadora maioria dos produtos químicos utilizados serem inflamáveis 44,9 \% dos trabalhadores (62 casos) ainda não teve formação no combate a incêndios (Figura 28) (Anexo 7.11 - Tabela 123).

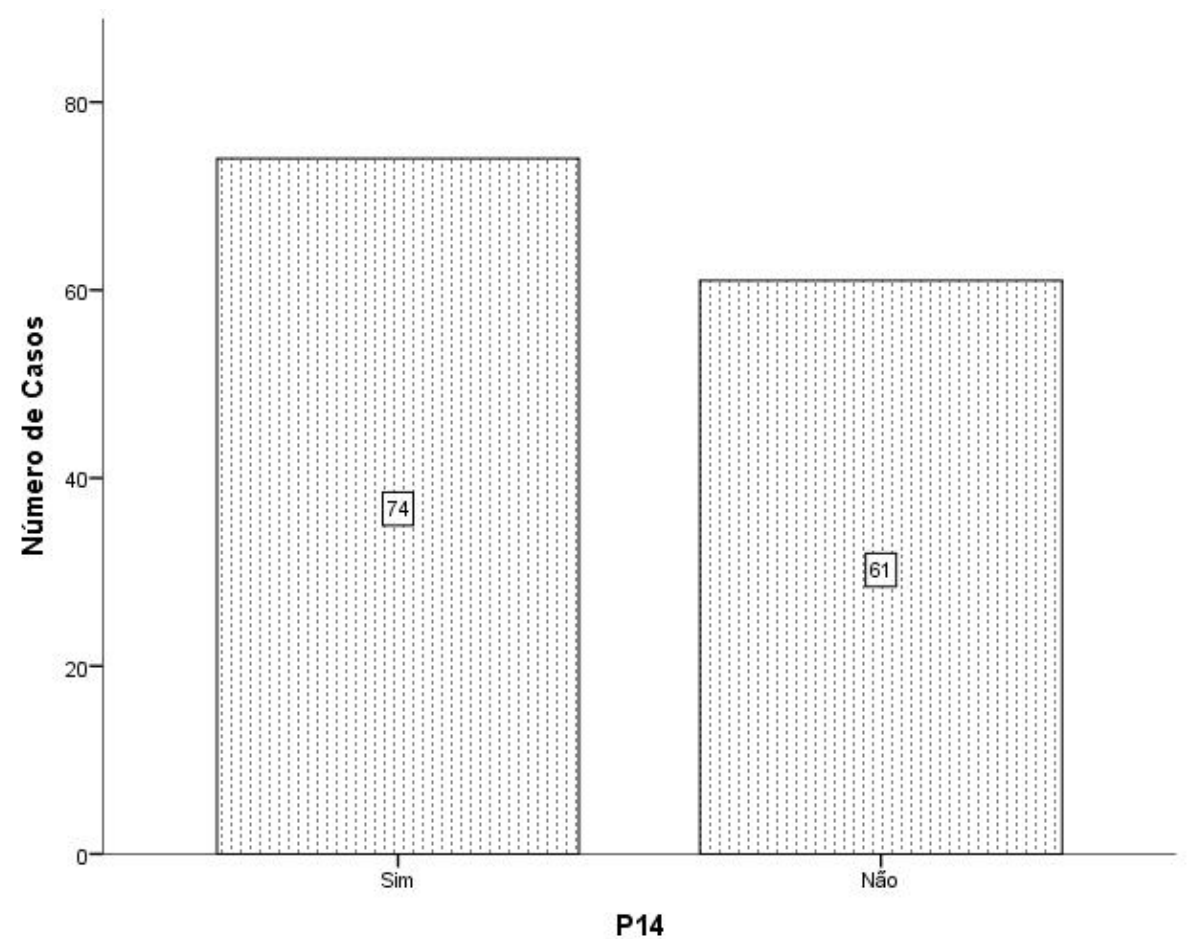

Figura 29 - Número de trabalhadores sobre a Formação dos Riscos dos Produtos Químicos

Dos trabalhadores inquiridos, 45,5 \% (61 casos) referiu que ainda não teve formação sobre os riscos dos produtos químicos (Figura 29) (Anexo 7.11 Tabela 124). 


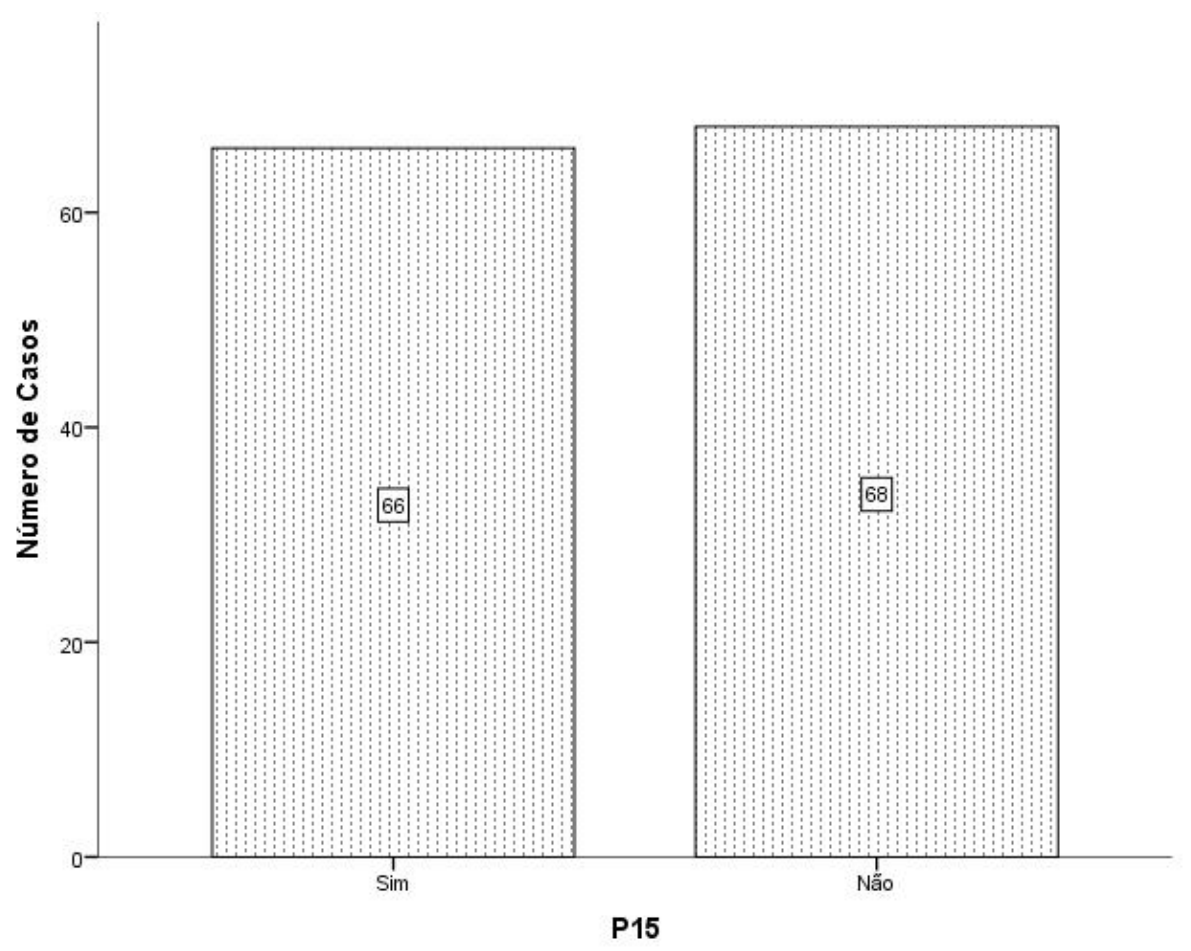

Figura 30 - Número de trabalhadores sobre a Formação no Manuseamento Correto dos Riscos dos Produtos Químicos

A maioria dos trabalhadores, 50,7 \% (68 casos) referiu que nunca teve formação no manuseamento correto dos produtos químicos (Figura 30) (Anexo 7.11 - Tabela 125). 


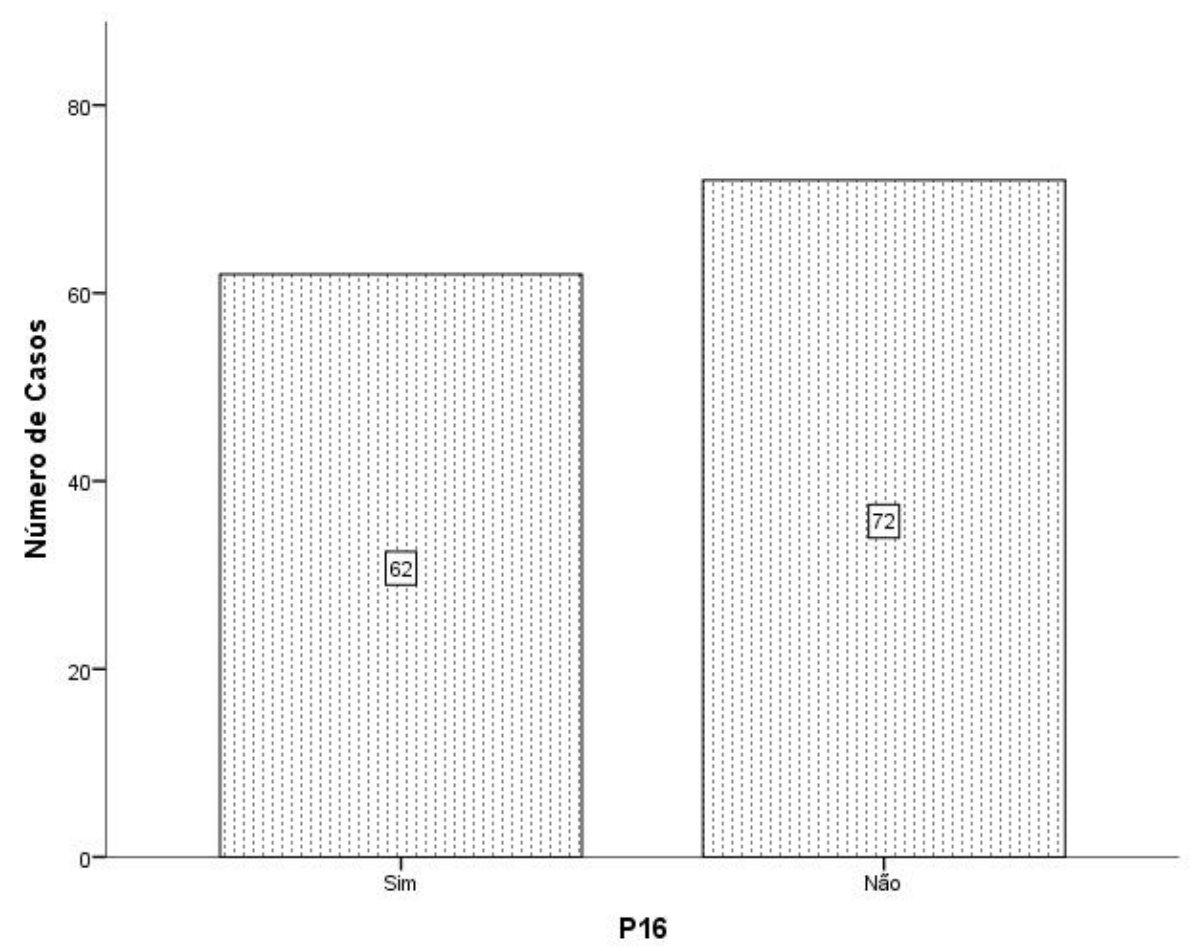

Figura 31 - Número de trabalhadores sobre a Formação em Como Proceder no Caso de Derrame dos Produtos Químicos

Este indicador é ainda pior porque 53,7 \% (72 casos) dos trabalhadores não teve formação de como proceder no caso de um derrame dos produtos químicos (Figura 31) (Anexo 7.11 - Tabela 126). 


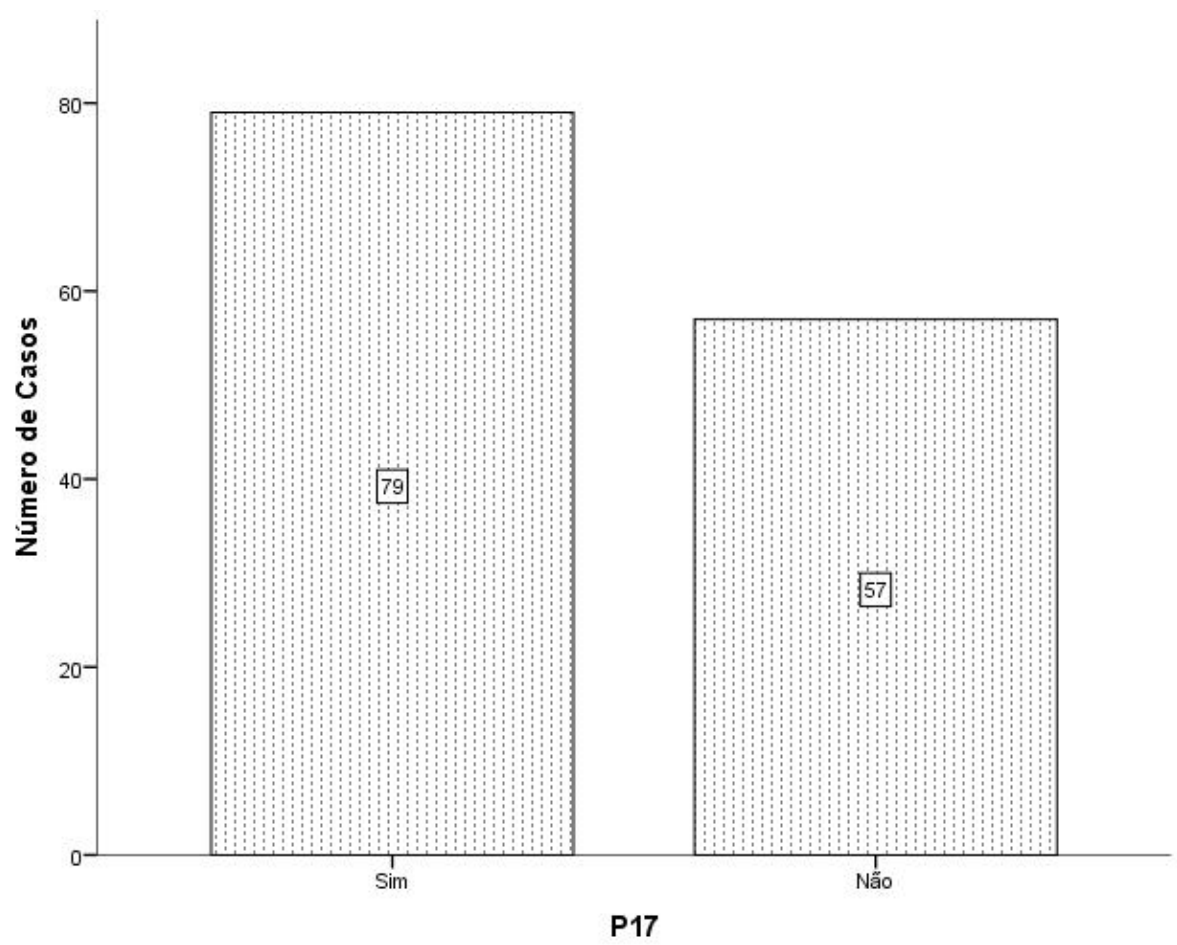

Figura 32 - Número de trabalhadores sobre a Formação em Saúde e Segurança na Aplicação dos Produtos Químicos

$\mathrm{Na}$ aplicação de produtos químicos, 58,1 \% (79 casos) referiu que já teve formação nas matérias de segurança e saúde (Figura 32) (Anexo 7.11 Tabela 127). 


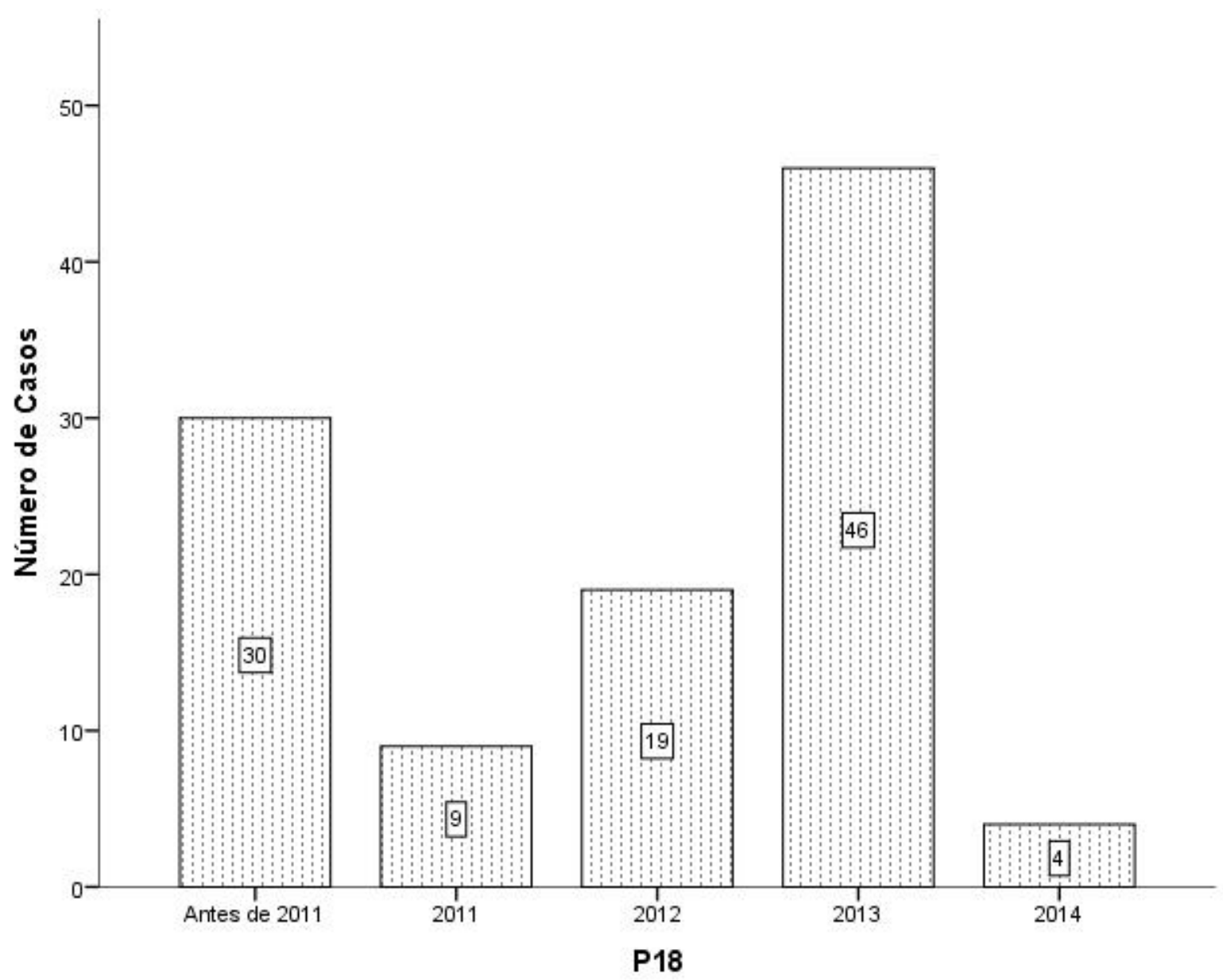

Figura 33 - Antiguidade da formação sobre os riscos laborais no posto de trabalho

Aproximadamente $42,6 \%$ (46 casos) trabalhadores referem que tiveram formação em 2013 em riscos laborais no posto de trabalho, 27,8 \% (30 casos) antes de 2011, 17,6 \% (19) em 2012, 8,3 \% (9 casos) em 2011 e 3,7 \% (4 casos) em 2014 (Figura 33) (Anexo 7.11 - Tabela 128). 


\subsection{Monitorizações do Ar Interior nas Zonas de Aplicação de Produtos Químicos}

\subsubsection{Níveis ambientais de tolueno, etilbenzeno e xileno}

Entre os dias 07 de julho e o dia 10 de novembro de 2014 foram recolhidas três amostras do ar interior das zonas de aplicação de tintas/velaturas, vernizes e tapa poros em 28 empresas, totalizando 108 amostras de ar.

Os valores de concentrações determinados nas amostras do ar recolhido apresentam-se nas Tabela 5 e Tabela 6.

Dos 36 locais de trabalho das 28 empresas estudadas, $39 \%$ das medições apresentam valores de concentrações superiores ao valor limite de exposição médio ponderado (VLE-MP) para o tolueno, ou seja, 50 ppm de

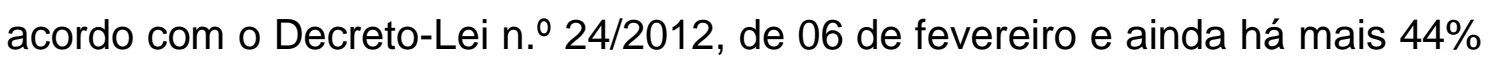
de locais de trabalho que apresentam concentrações superiores a 20 ppm, valor limite de exposição médio ponderado estabelecido na Norma Portuguesa 1796:2014 (NP 1796:2014). Assim, conclui-se que 83\% dos locais de trabalho apresentam valores de concentração de tolueno acima do estabelecido na NP 1796:2014 (Tabela 5 e Tabela 6) (Figura 34). 
Tabela 5 - Concentração média ponderada no ar interior

\begin{tabular}{|c|c|c|c|c|c|c|c|}
\hline \multirow[b]{2}{*}{$\begin{array}{l}\text { Empresa/ } \\
\text { local de } \\
\text { trabalho }\end{array}$} & \multicolumn{7}{|c|}{ Concentração Média Ponderada (ppm) } \\
\hline & Tolueno & Etilbenzeno & Xileno & $\begin{array}{l}\text { Empresa/ } \\
\text { local de } \\
\text { trabalho }\end{array}$ & Tolueno & Etilbenzeno & Xileno \\
\hline $\mathrm{A} 1$ & 14 & 26 & 101 & M & 22 & 9 & 19 \\
\hline $\mathrm{A} 2$ & 50 & 23 & 92 & $\mathrm{~N}$ & 13 & 9 & 52 \\
\hline AA & 52 & 33 & 89 & $\mathrm{O}$ & 61 & 56 & 119 \\
\hline$A B$ & 0 & 0 & 0 & $P$ & 21 & 21 & 31 \\
\hline$A C$ & 168 & 27 & 63 & Q & 22 & 18 & 31 \\
\hline B & 42 & 39 & 85 & Q2 & 19 & 18 & 20 \\
\hline C & 40 & 37 & 55 & $\mathrm{R}$ & 39 & 43 & 100 \\
\hline D & 36 & 33 & 73 & $S$ & 152 & 33 & 104 \\
\hline$E$ & 12 & 19 & 34 & $\mathrm{~T}$ & 26 & 34 & 79 \\
\hline E1 & 12 & 19 & 22 & T2 & 121 & 27 & 51 \\
\hline$F$ & 76 & 18 & 74 & $U$ & 111 & 19 & 43 \\
\hline $\mathrm{G}$ & 28 & 15 & 83 & V & 31 & 13 & 58 \\
\hline $\mathrm{H}$ & 21 & 21 & 62 & V2 & 58 & 16 & 34 \\
\hline I & 132 & 23 & 47 & W & 45 & 10 & 24 \\
\hline 12 & 99 & 19 & 44 & $X$ & 36 & 18 & 49 \\
\hline $\mathrm{J}$ & 68 & 32 & 75 & X2 & 61 & 28 & 71 \\
\hline $\mathrm{K}$ & 30 & 21 & 25 & $Y$ & 63 & 20 & 35 \\
\hline L & 27 & 10 & 27 & Z & 40 & 39 & 83 \\
\hline
\end{tabular}


Resultados

Tabela 6 - Concentração de curta duração no ar interior

\begin{tabular}{|c|c|c|c|c|c|c|c|}
\hline \multirow[b]{2}{*}{$\begin{array}{l}\text { Empresa/ } \\
\text { local de } \\
\text { trabalho }\end{array}$} & \multicolumn{7}{|c|}{ Concentração de Curta Duração (ppm) } \\
\hline & Tolueno & Etilbenzeno & Xileno & $\begin{array}{l}\text { Empresa/ } \\
\text { local de } \\
\text { trabalho }\end{array}$ & Tolueno & Etilbenzeno & Xileno \\
\hline \multirow[t]{3}{*}{ A1 } & 20 & 31 & 116 & $\mathrm{E} 1$ & 11 & 19 & 23 \\
\hline & 18 & 39 & 154 & & 13 & 19 & 21 \\
\hline & 0 & 0 & 0 & $\mathrm{~F}$ & 99 & 20 & 31 \\
\hline \multirow[t]{3}{*}{ A2 } & 38 & 23 & 132 & & 87 & 18 & 137 \\
\hline & 34 & 15 & 32 & & 24 & 16 & 45 \\
\hline & 57 & 18 & 39 & $\mathrm{G}$ & 15 & 20 & 27 \\
\hline \multirow[t]{3}{*}{ AA } & 49 & 20 & 29 & & 36 & 12 & 111 \\
\hline & 60 & 55 & 190 & & 36 & 11 & 127 \\
\hline & 46 & 18 & 25 & $\mathrm{H}$ & 20 & 25 & 64 \\
\hline \multirow[t]{3}{*}{$A B$} & 0 & 0 & 0 & & 24 & 19 & 63 \\
\hline & 0 & 0 & 0 & & 17 & 18 & 59 \\
\hline & 0 & 0 & 0 & 1 & 124 & 20 & 22 \\
\hline \multirow[t]{3}{*}{$A C$} & 108 & 24 & 66 & & 162 & 28 & 68 \\
\hline & 201 & 28 & 77 & & 108 & 19 & 42 \\
\hline & 418 & 58 & 74 & 12 & 99 & 19 & 44 \\
\hline \multirow[t]{3}{*}{ B } & 72 & 69 & 149 & $\mathrm{~J}$ & 70 & 22 & 56 \\
\hline & 24 & 18 & 48 & & 65 & 21 & 58 \\
\hline & 34 & 35 & 70 & & 70 & 62 & 128 \\
\hline \multirow[t]{3}{*}{ C } & 57 & 54 & 69 & K & 23 & 20 & 19 \\
\hline & 27 & 25 & 35 & & 31 & 21 & 29 \\
\hline & 32 & 30 & 64 & & 38 & 21 & 28 \\
\hline \multirow[t]{3}{*}{ D } & 34 & 31 & 70 & L & 31 & 11 & 27 \\
\hline & 41 & 38 & 83 & & 21 & 8 & 34 \\
\hline & 32 & 28 & 64 & & 29 & 11 & 19 \\
\hline \multirow[t]{3}{*}{$E$} & 13 & 22 & 33 & $M$ & 19 & 10 & 17 \\
\hline & 13 & 15 & 41 & & 23 & 9 & 17 \\
\hline & 11 & 20 & 24 & & 25 & 9 & 23 \\
\hline
\end{tabular}




\begin{tabular}{|c|c|c|c|c|c|c|c|}
\hline \multirow[b]{2}{*}{$\begin{array}{l}\text { Empresa/ } \\
\text { local de } \\
\text { trabalho }\end{array}$} & \multicolumn{7}{|c|}{ Concentração de Curta Duração (ppm) } \\
\hline & Tolueno & Etilbenzeno & Xileno & $\begin{array}{l}\text { Empresa/ } \\
\text { local de } \\
\text { trabalho }\end{array}$ & Tolueno & Etilbenzeno & Xileno \\
\hline \multirow[t]{3}{*}{$\mathrm{N}$} & 10 & 11 & 29 & $U$ & 162 & 30 & 68 \\
\hline & 11 & 7 & 67 & & 92 & 11 & 25 \\
\hline & 22 & 9 & 63 & & 64 & 15 & 34 \\
\hline \multirow[t]{3}{*}{$\mathrm{O}$} & 57 & 75 & 132 & V & 41 & 14 & 60 \\
\hline & 31 & 50 & 89 & & 25 & 13 & 51 \\
\hline & 113 & 34 & 145 & & 24 & 13 & 65 \\
\hline \multirow[t]{3}{*}{$P$} & 25 & 22 & 33 & V2 & 58 & 16 & 34 \\
\hline & 19 & 21 & 33 & W & 25 & 9 & 21 \\
\hline & 18 & 20 & 27 & & 55 & 11 & 26 \\
\hline \multirow[t]{3}{*}{$Q$} & 24 & 15 & 32 & & 60 & 10 & 25 \\
\hline & 20 & 23 & 31 & $x$ & 34 & 17 & 45 \\
\hline & 24 & 15 & 31 & & 33 & 16 & 43 \\
\hline Q2 & 19 & 18 & 20 & & 44 & 21 & 62 \\
\hline \multirow[t]{3}{*}{$\mathrm{R}$} & 38 & 48 & 102 & $\mathrm{X} 2$ & 59 & 27 & 66 \\
\hline & 47 & 45 & 113 & & 68 & 23 & 58 \\
\hline & 31 & 30 & 77 & & 55 & 37 & 97 \\
\hline \multirow[t]{3}{*}{$S$} & 118 & 25 & 75 & Y & 51 & 24 & 31 \\
\hline & 174 & 31 & 107 & & 74 & 18 & 39 \\
\hline & 171 & 49 & 142 & & 63 & 16 & 35 \\
\hline \multirow[t]{3}{*}{$\mathrm{T}$} & 27 & 34 & 79 & Z & 36 & 33 & 62 \\
\hline & 26 & 37 & 88 & & 52 & 48 & 116 \\
\hline & 24 & 29 & 67 & & 29 & 33 & 66 \\
\hline \multirow[t]{3}{*}{ T2 } & 32 & 25 & 54 & & & & \\
\hline & 27 & 28 & 37 & & & & \\
\hline & 201 & 22 & 48 & & & & \\
\hline
\end{tabular}




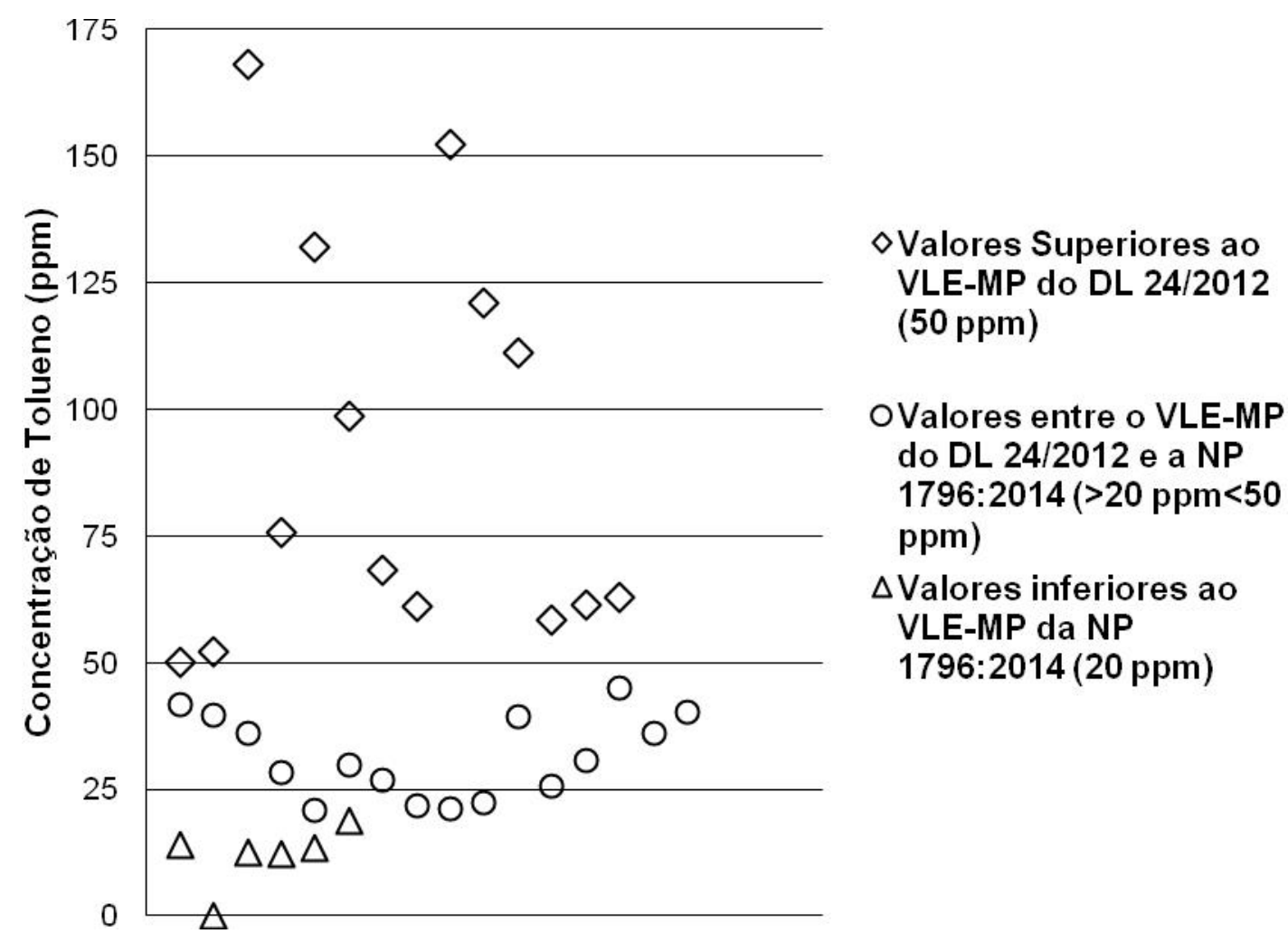

Figura 34 - Deslocação das concentrações médias ponderadas do tolueno versus valores de referência

Aproximadamente $12 \%$ das amostras de ar apresentam valores superiores ao valor limite de exposição de curta duração (VLE-CD) para o tolueno, ou seja, 100 ppm estabelecido no Decreto-Lei n.․ 24/2012, de 06 de fevereiro. A NP 1796:2014 não define valor limite de exposição de curta duração (Tabela 6 e Figura 35), para o referido composto. 


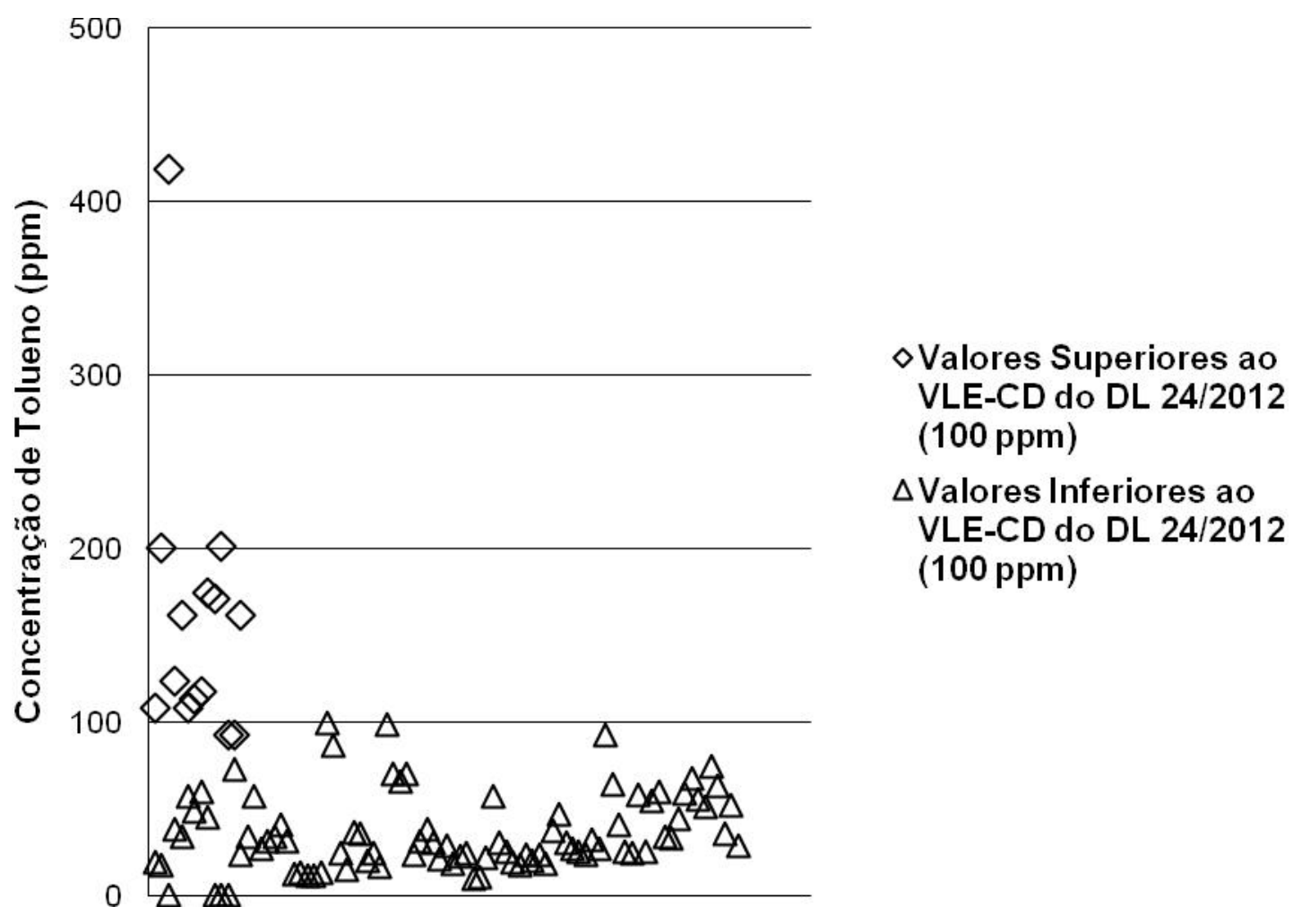

Figura 35 - Deslocação das concentrações de curta duração do tolueno, segundo o DL $24 / 2012$

Nenhuma das amostras de ar analisadas apresentam concentrações de etilbenzeno que excedam os VLE-MP para o referido composto, definido no Decreto-Lei n. ${ }^{\circ}$ 24/2012, de 06 de fevereiro, isto é de 100 ppm, no entanto, verifica-se que $56 \%$ dos valores estão acima de 20 ppm preconizado na NP 1796:2014 (Figura 36).

Quanto à comparação das concentrações encontradas de etilbenzeno verifica-se que não há valores superiores ao VLE-CD, ou seja, 200 ppm estabelecido no Decreto-Lei n.ำ 24/2012, de 06 de fevereiro. A NP 1796:2014 não define valor limite de exposição de curta duração para o referido composto. 


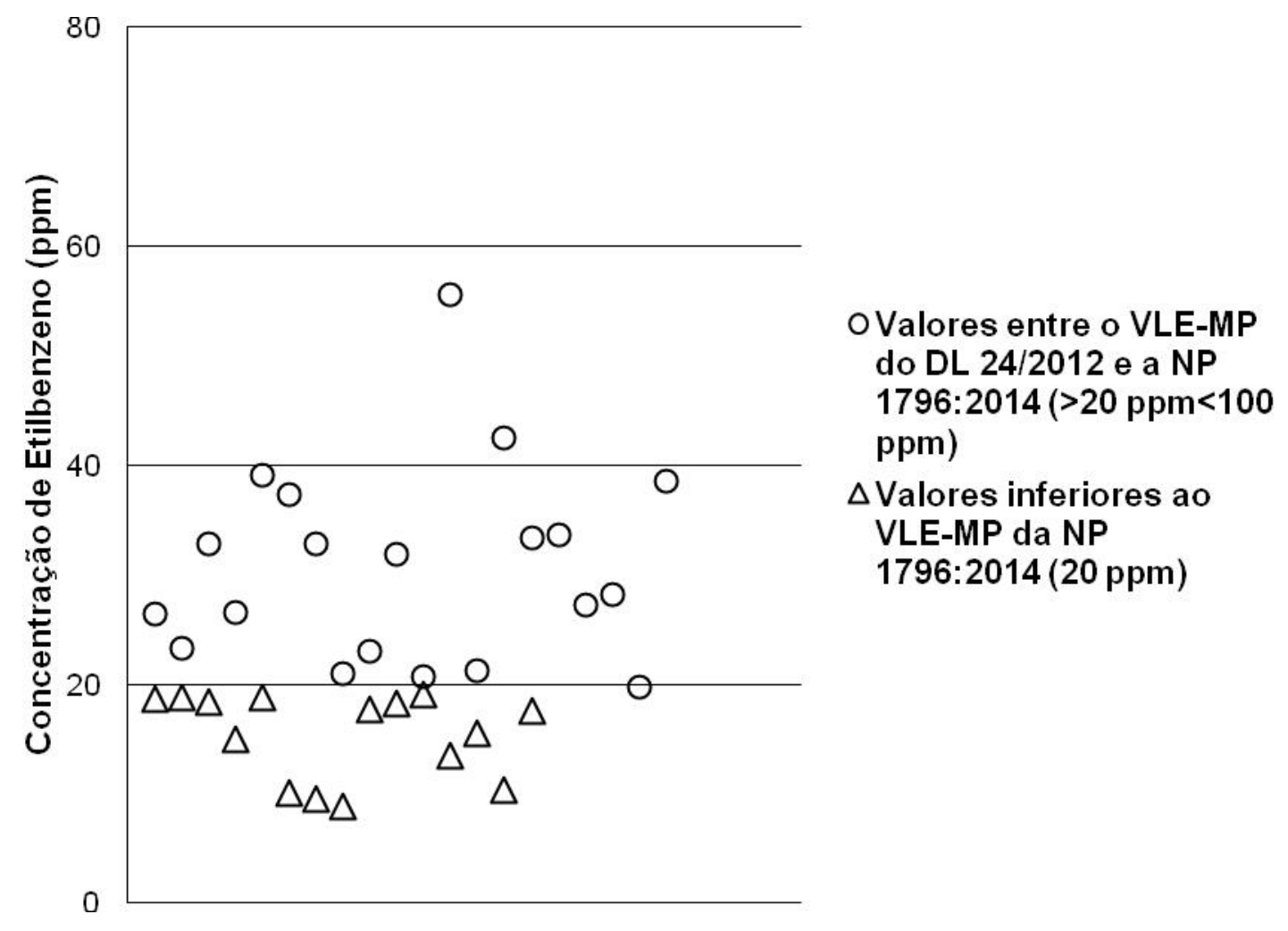

Figura 36 - Deslocação das concentrações médias ponderadas do etilbenzeno versus valores de referência

Sensivelmente $56 \%$ das amostras de ar revelam concentrações de xileno superiores ao VLE-MP definido para este composto através do DecretoLei n.. 24/2012, de 06 de fevereiro (50 ppm) e 8\% das amostras encontram-se acima do VLE-MP estabelecido na NP 1796:2014 (100 ppm) (Figura 37).

Aproximadamente $16 \%$ das amostras de ar acusam concentrações

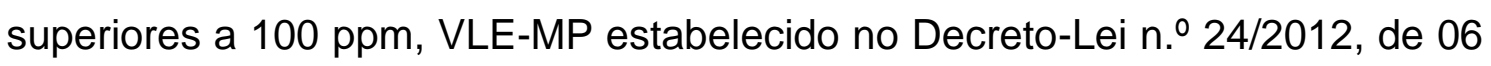
de fevereiro para o VLE-CD e somente $2 \%$ das avaliações se encontram acima dos valores limite, isto é, 150 ppm segundo a NP 1796:2014 (Figura 38). 


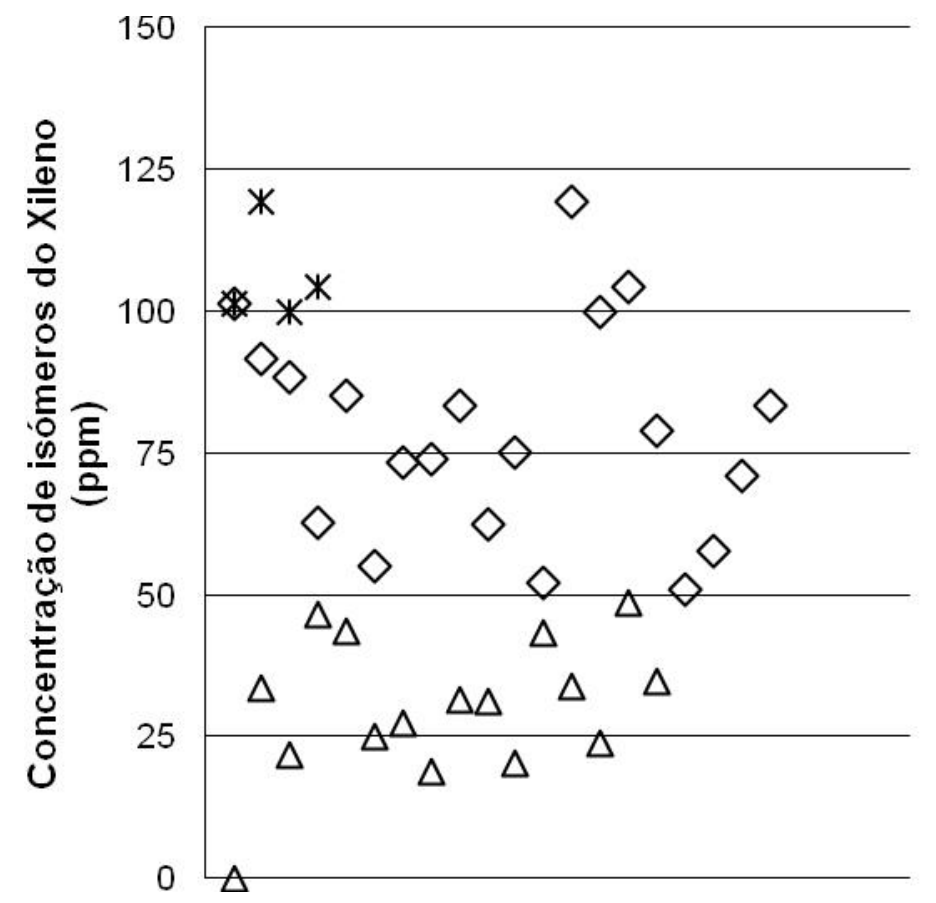

$\diamond$ Valores Superiores ao VLE-MP do DL 24/2012 (50 ppm)

$\triangle$ Valores inferiores ao VLE-MP do DL 24/2012 $(50 \mathrm{ppm})$

* Valores Superiores ao VLE-MP da NP 1796:2014 (100 ppm)

Figura 37 - Deslocação das concentrações médias ponderadas de isómeros do xileno versus valores de referência 


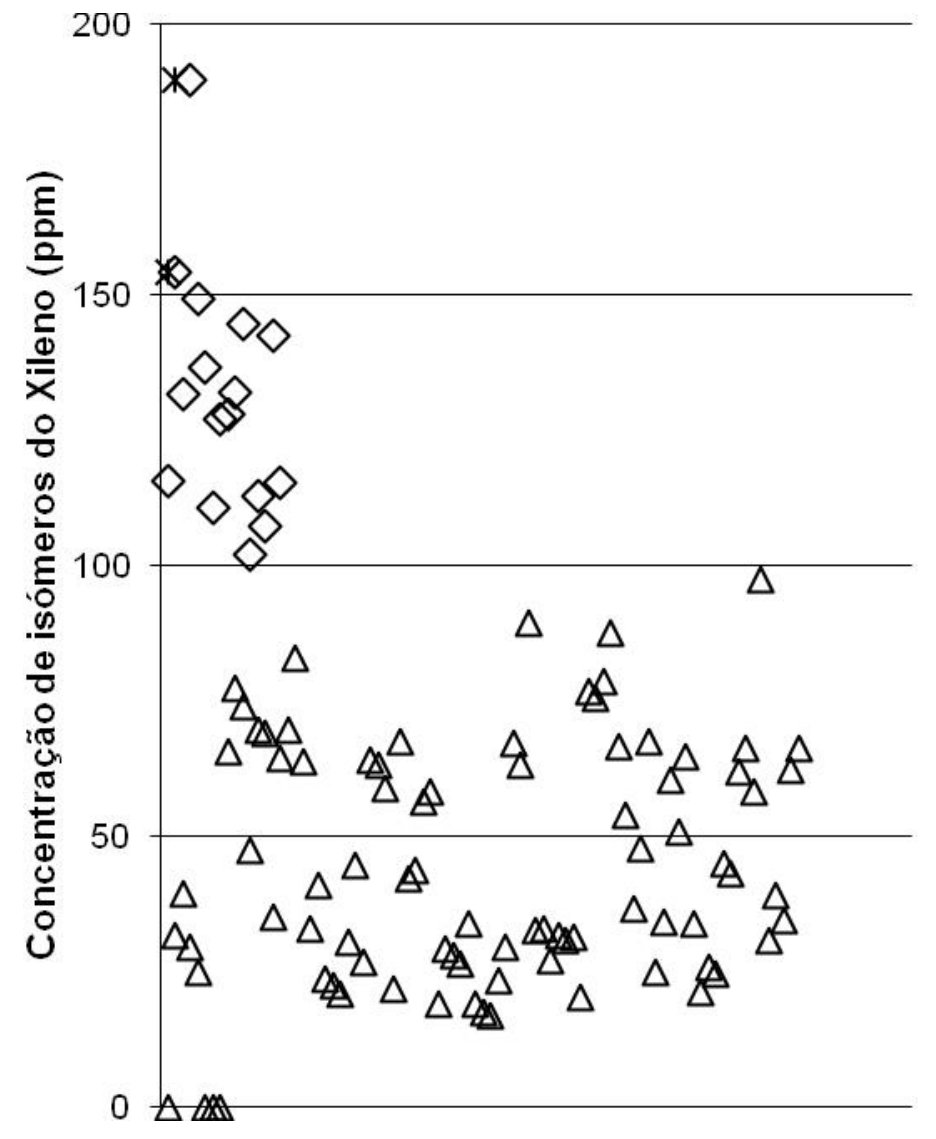

$\diamond$ Valores Superiores ao VLE-CD do DL 24/2012 (100 ppm)

$\triangle$ Valores Inferiores ao VLE-CD do DL 24/2012 $(100 \mathrm{ppm})$

$*$ Valores Superiores ao VLE-CD à NP 1796:2014 (150 ppm)

Figura 38 - Deslocação das concentrações de curta duração de isómeros do xileno versus valores de referência

Os valores limite de exposição (VLE) são desenvolvidos para substâncias isoladas, contudo, a realidade dos postos de trabalho leva-nos a concluir que estes ambientes são compostos por diversas substâncias originando exposições múltiplas. Para considerar estas exposições múltiplas foi desenvolvido o modelo aditivo descrito na norma NP 1796:2014.

Assim, quando dois ou mais agentes químicos têm efeitos toxicológicos semelhantes sobre o mesmo órgão ou sistema e estão presentes simultaneamente no ar do ambiente de trabalho, deve ser considerado o seu efeito aditivo em vez do efeito isolado de cada um. Se o somatório:

$$
\mathrm{C}_{1} / \mathrm{VLE}_{1}+\mathrm{C}_{2} / \mathrm{VLE}_{2}+\ldots .+\mathrm{C}_{\mathrm{n}} / \mathrm{VLE}_{\mathrm{n}}>1
$$


Onde:

$\mathrm{C}_{\mathrm{n}}$ - concentração atmosférica encontrada para o agente $\mathrm{n}$

$V_{L} E_{n}-\quad$ valor limite de exposição correspondente ao agente $n$

Portanto, se a mistura for superior a 1, então o VLE da mesma é considerado excedido.

Considerando este efeito aditivo entre os isómeros de xileno, tolueno e etilbenzeno, presentes no ar dos locais de trabalho analisados, na Figura 39, verifica-se que $92 \%$ das exposições à mistura excede o valor limite de exposição (>1) e apenas $8 \%$ é inferior ao valor limite de exposição $(<1)$.

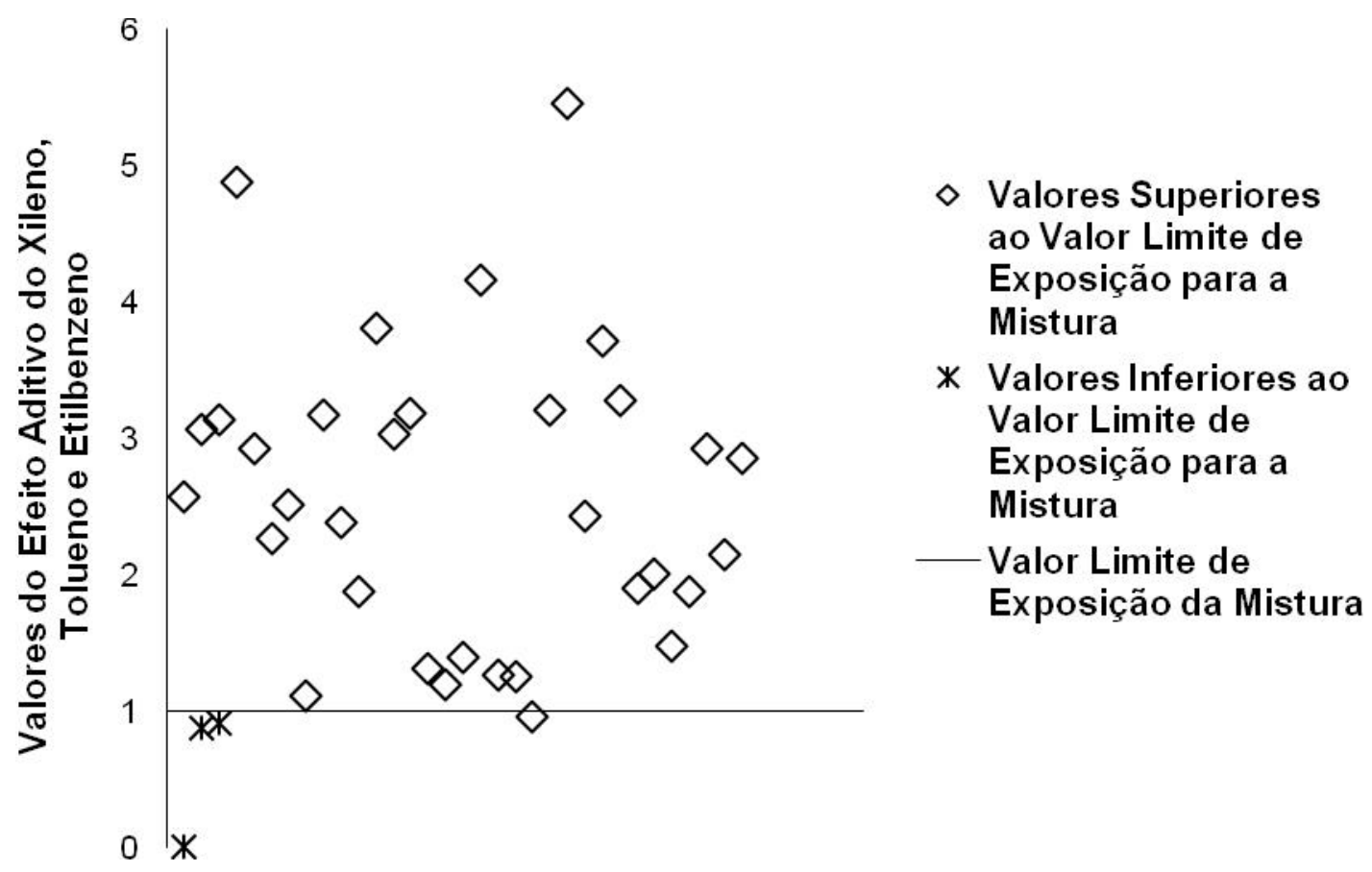

Figura 39 - Deslocação da média ponderada aplicando o efeito aditivo da exposição aos isómeros do xileno, tolueno e etilbenzeno 


\subsubsection{Monitorizações Biológicas}

Neste subcapítulo apresentam-se os resultados dos indicadores biológicos de exposição ao Xileno, Etilbenzeno e Tolueno referentes a uma amostra de 124 trabalhadores do setor de aplicação de tintas/velaturas, vernizes e tapa poros das 28 empresas de fabrico de mobiliário.

\subsubsection{Níveis Urinários de Ácidos Metilhipúricos (AMH), Ácido Mandélico (AM), Ácido Fenilglioxílico (AFG), Ácido Hipúrico (AH) e o-cresol}

As concentrações médias dos indicadores biológicos de exposição ao xileno, ao etilbenzeno e ao tolueno antes e após a exposição encontram-se na Tabela 7.

Tabela 7 - Níveis médios dos indicadores biológicos de exposição de Xileno (o-MHA, m-MHA e p-MHA), Etilbenzeno (AM e AFG) e Tolueno (AH e o-cresol) na urina, antes e após a exposição

\begin{tabular}{|c|c|c|c|c|c|}
\hline & $\mathbf{N}$ & \multicolumn{2}{|c|}{ Antes da Exposição } & \multicolumn{2}{|c|}{ Após a Exposição } \\
\hline & & Média \pm DVP & Gama & Média \pm DVP & Gama \\
\hline Ácidos Metilhipúricos & & ND & - & $1,6 \pm 0,7$ & $0,3-3,4$ \\
\hline $\begin{array}{l}\text { Ácido Fenilglioxílico } \\
\text { Ácido Mandélico }\end{array}$ & 124 & $\begin{array}{l}\text { ND } \\
\text { ND }\end{array}$ & $\begin{array}{c}- \\
<0,1\end{array}$ & $0,3 \pm 0,1$ & $0,0-0,5$ \\
\hline Ácido Hipúrico & & ND & - & $1,9 \pm 1,7$ & $0,1-8,3$ \\
\hline o-Cresol & & ND & - & 0,3 & $0,0-1,5$ \\
\hline
\end{tabular}


Nas amostras de urina recolhidas antes da exposição não se detetaram indicadores biológicos de exposição. Após uma semana de jornada laboral e com 8 horas diárias de exposição, detetaram-se em média 1,6 g/g de creatinina de ácido metilhipurico, $0,3 \mathrm{~g} / \mathrm{g}$ de creatinina do somatório do ácido fenilglioxilico com o ácido mandélico, 1,9 g/g de creatinina de ácido hipúrico e 0,3 mg/g de creatinina de o-cresol (Tabela 7).

Tabela 8 - Relação linear entre o xileno, o etilbenzeno e o tolueno no ar e os indicadores biológicos de exposição na urina

Coeficiente de

Correlação

Xileno (ppm)-o, m, e p-MHA (g/g de creatinina)
Etilbenzeno (ppm)-AM e AFG (g/g de creatinina)
Tolueno (ppm)-AH (g/g de creatinina)

Tolueno (ppm)-o-cresol (mg/g de creatinina)

$\begin{array}{ll}0,73 & 0,000 \\ 0,93 & 0,000 \\ 0,77 & 0,000 \\ 0,76 & 0,000\end{array}$

Nível de Significância

0,000

0,000

0,000

Pela análise da Tabela 8 observa-se uma boa correlação entre os níveis ambientais dos compostos orgânicos voláteis analisados e os seus indicadores biológicos de exposição na urina (Figura 40, Figura 41, Figura 42 e Figura 43). 


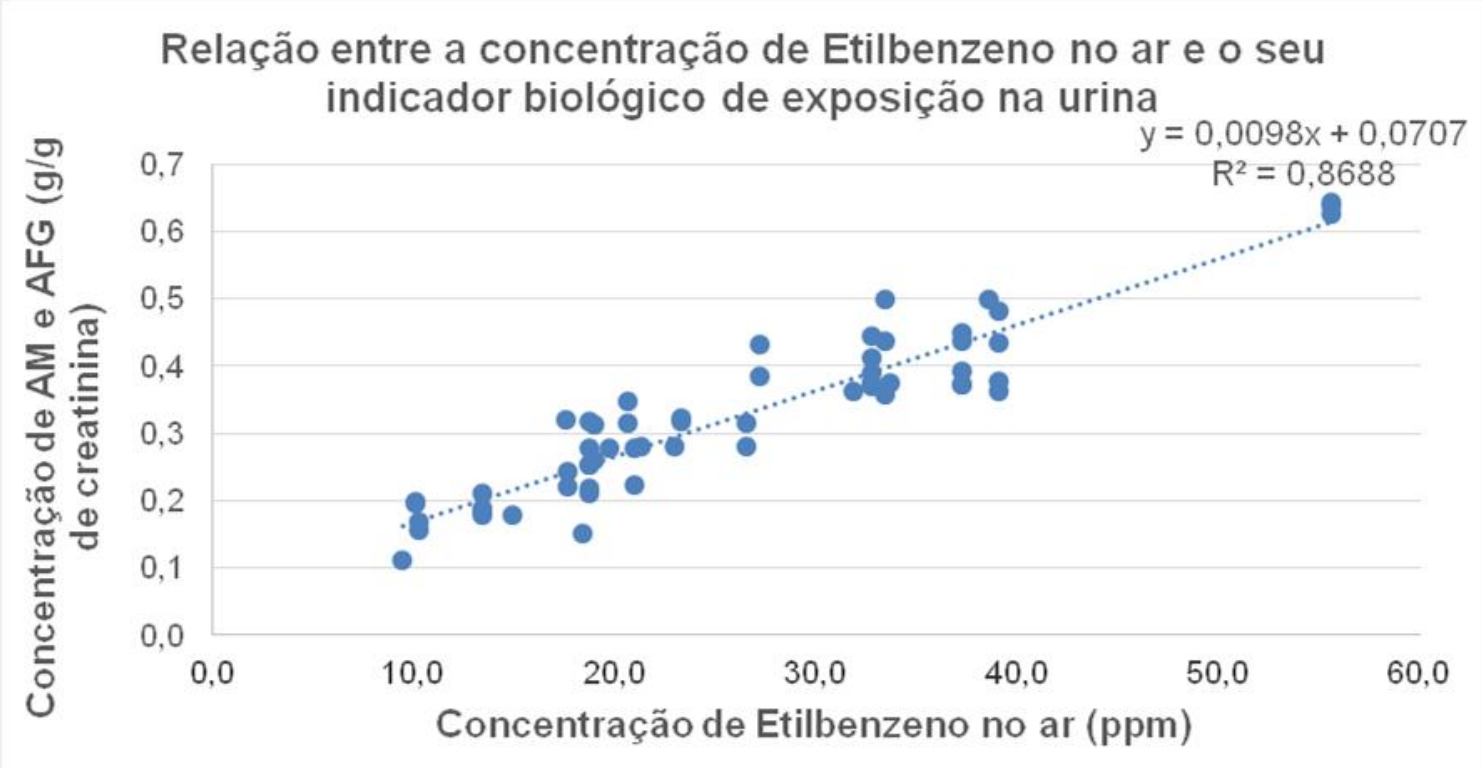

Figura 40 - Relação linear entre o etilbenzeno no ar e a soma do ácido mandélico e do ácido fenilglioxílico na urina

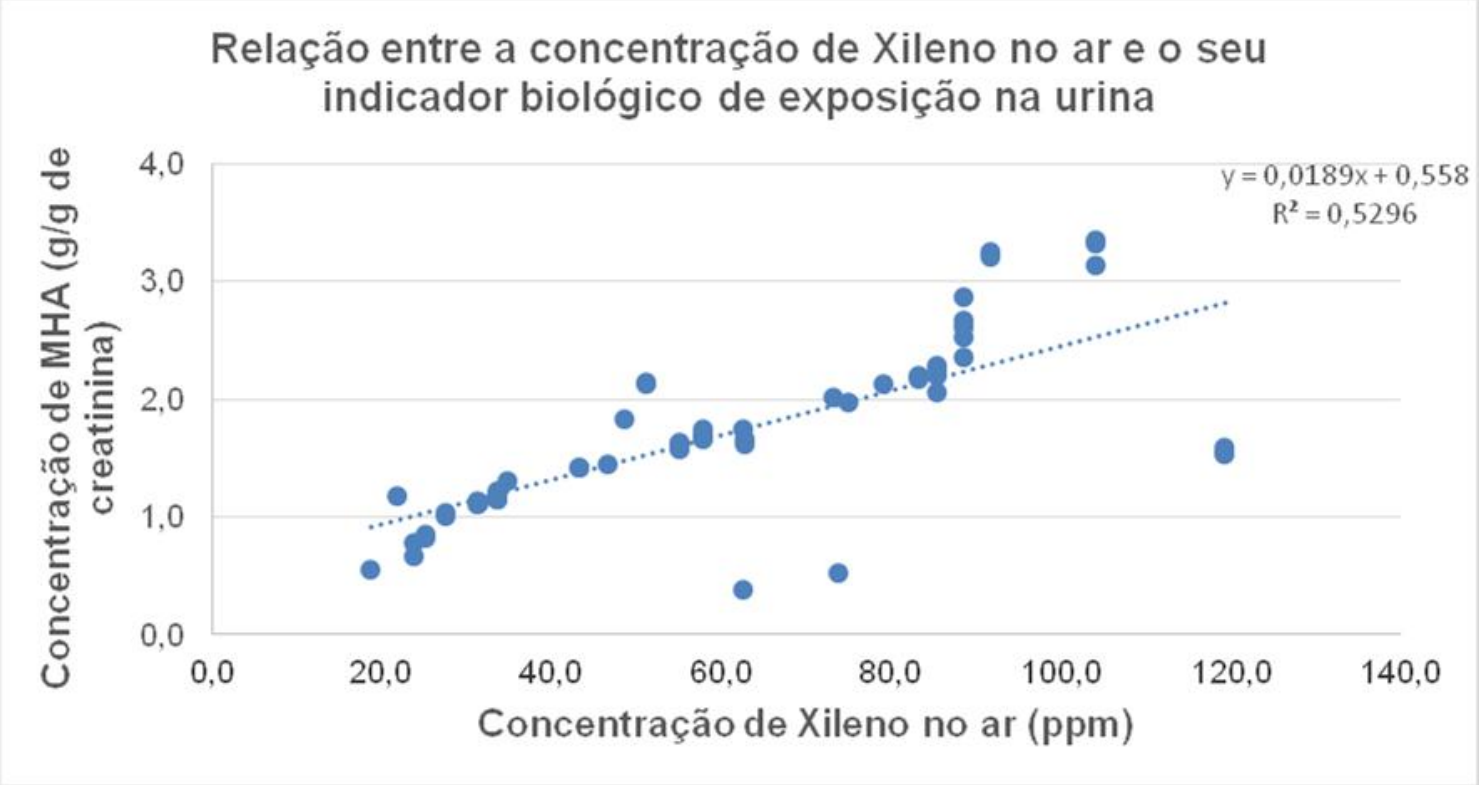

Figura 41 - Relação linear entre o xileno no ar e dos ácidos (o, m, p)-metilhipúricos na urina 
Relação entre a concentração de Tolueno no ar e o seu indicador biológico de exposição na urina

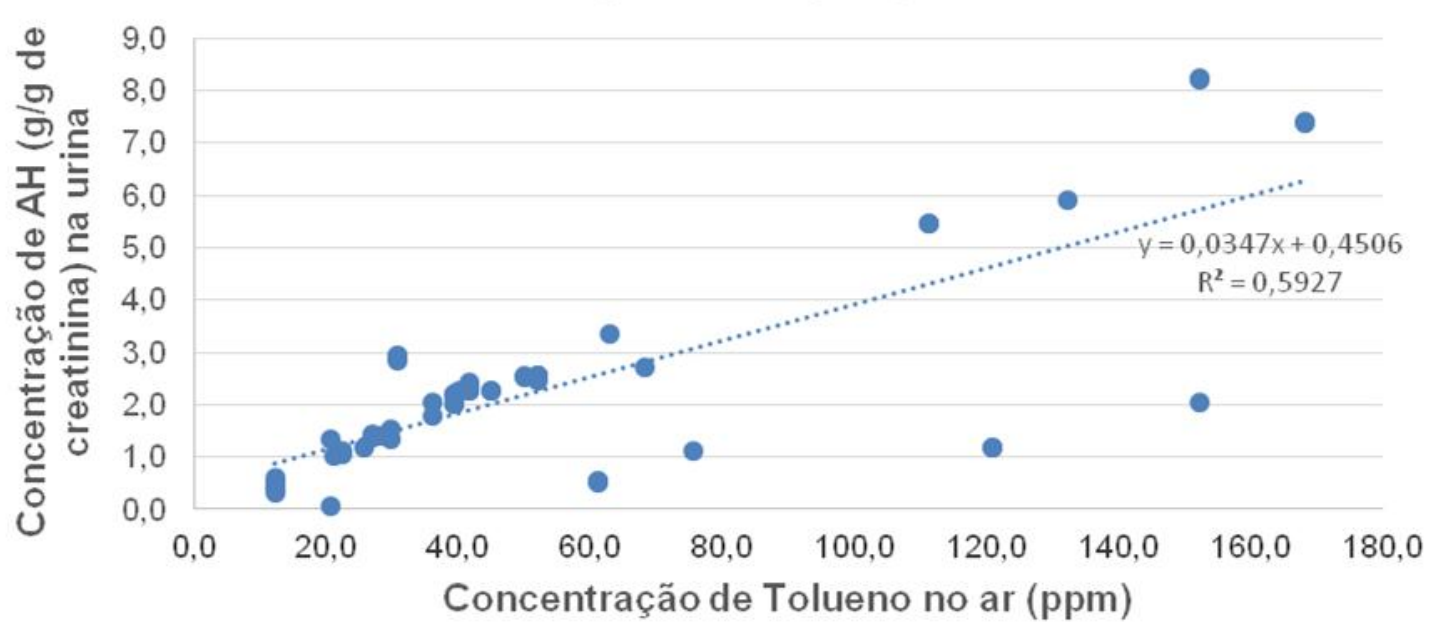

Figura 42 - Relação linear entre o tolueno no ar e do ácido hipúrico na urina

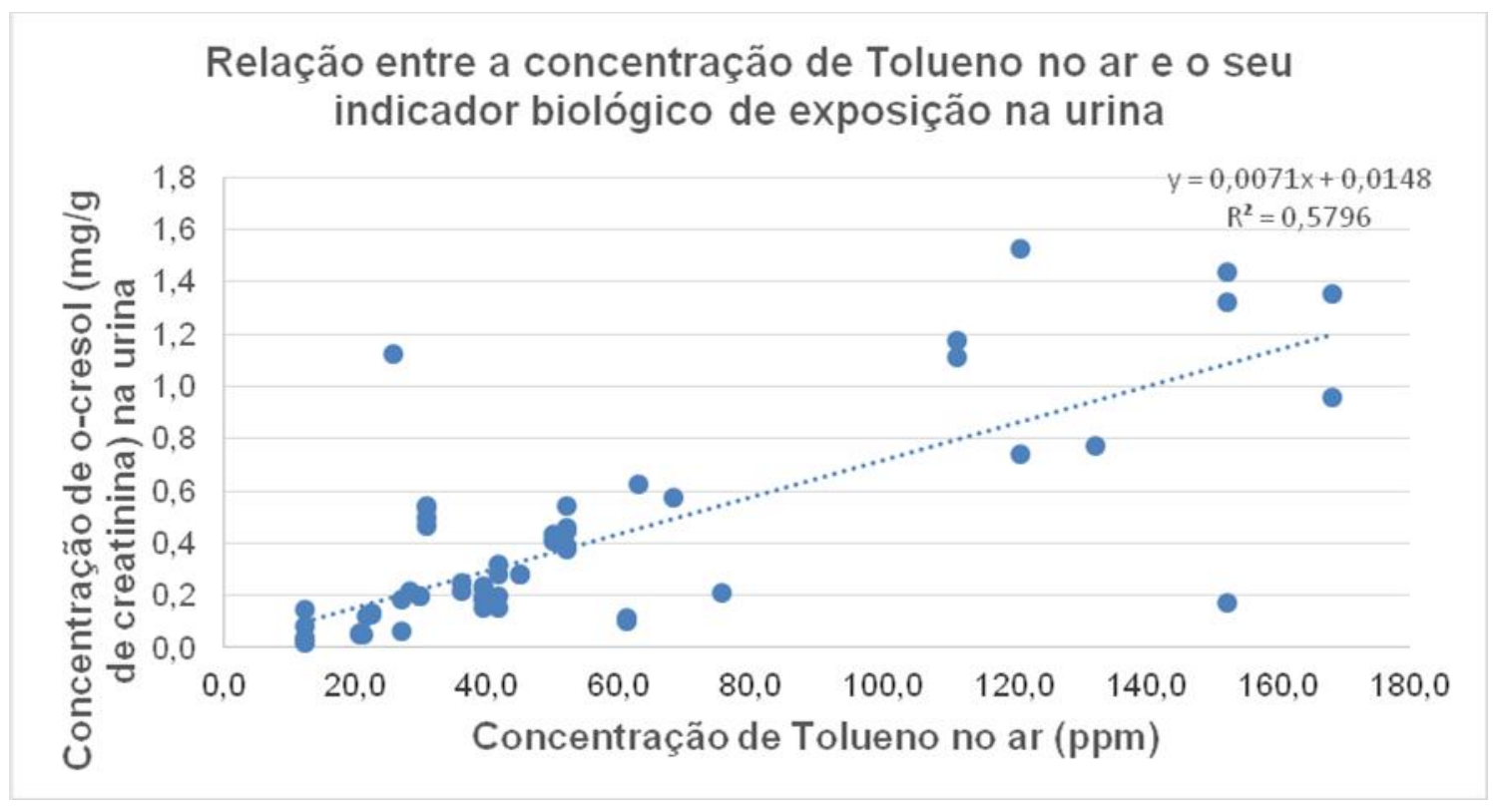

Figura 43 - Relação linear entre o tolueno no ar e o-cresol na urina 
$\mathrm{Na}$ Tabela 9, apresentam-se os valores obtidos no teste de t-student para os diferentes metabolitos dos isómeros do xileno, tolueno e etilbenzeno na urina, dos trabalhadores antes (A) e após (B) a exposição, verificando-se a existência de diferenças estatisticamente significativas entre os grupos.

Tabela 9 - Níveis urinários dos ácidos mandélico, fenilglioxílico, hipúrico e metilhipúricos antes e após a exposição ao etilbenzeno, ao tolueno e ao xileno pelo teste t-Student, com um nível de significância de $5 \%$

\begin{tabular}{|c|c|c|c|c|c|c|}
\hline \multirow{2}{*}{$\begin{array}{l}\text { Indicador Biológico de } \\
\text { Exposição }\end{array}$} & \multirow{2}{*}{ Tipo* } & \multirow{2}{*}{$\begin{array}{c}\text { Número } \\
\text { de } \\
\text { Amostras }\end{array}$} & \multirow{2}{*}{$\begin{array}{c}\text { Concentração } \\
\text { Média (g/g } \\
\text { creatinina) }\end{array}$} & \multicolumn{2}{|c|}{ Teste t-Student } & \multirow{2}{*}{ Valor $p$} \\
\hline & & & & $t_{\text {calculado }}$ & $t_{\text {tabelado }}$ & \\
\hline Ácido Mandélico e & $A$ & 59 & $0,03 \pm 0,01$ & \multirow{2}{*}{$-19,5$} & \multirow{2}{*}{2,00} & \multirow{2}{*}{$<0,05$} \\
\hline Fenilglioxílico & B & 59 & $0,33 \pm 0,12$ & & & \\
\hline \multirow{2}{*}{ Ácidos Hipúrico } & $A$ & 59 & ND & \multirow{2}{*}{$-9,4$} & \multirow{2}{*}{2,00} & \multirow{2}{*}{$<0,05$} \\
\hline & B & 59 & $2,33 \pm 1,90$ & & & \\
\hline \multirow{2}{*}{ Ácidos Metilhipúricos } & $A$ & 59 & ND & \multirow{2}{*}{$-18,28$} & \multirow{2}{*}{2,00} & \multirow{2}{*}{$<0,05$} \\
\hline & B & 59 & $1,73 \pm 0,53$ & & & \\
\hline
\end{tabular}

\footnotetext{
${ }^{*} A-$ Antes da Exposição

B - Após a Exposição

ND - Não detetado
} 
$\mathrm{Na}$ Tabela 10, apresentam-se os valores obtidos no teste de t-student para o indicador biológico de exposição ao tolueno na urina, dos trabalhadores antes (A) e após (B) a exposição, verificando-se a existência de diferenças estatisticamente significativas entre os grupos.

Tabela 10 - Níveis urinários de o-cresol antes e após a exposição ao tolueno pelo teste tStudent, com um nível de significância de 5\%

\begin{tabular}{|c|c|c|c|c|c|c|}
\hline \multirow{2}{*}{$\begin{array}{l}\text { Indicador Biológico de } \\
\text { Exposição }\end{array}$} & \multirow[t]{2}{*}{ Tipo* } & \multirow{2}{*}{$\begin{array}{c}\text { Número } \\
\text { de } \\
\text { Amostras }\end{array}$} & \multirow{2}{*}{$\begin{array}{c}\text { Concentração } \\
\text { Média (mg/g } \\
\text { creatinina) }\end{array}$} & \multicolumn{2}{|c|}{$\begin{array}{l}\text { Teste t- } \\
\text { Student }\end{array}$} & \multirow[t]{2}{*}{ Valor $p$} \\
\hline & & & & tcalculado & ttabelado & \\
\hline \multirow{2}{*}{ o-cresol } & $A$ & 59 & $0,03 \pm 0,01$ & \multirow{2}{*}{$-7,8$} & \multirow{2}{*}{2,00} & \multirow{2}{*}{$<0,05$} \\
\hline & B & 59 & $0,40 \pm 0,39$ & & & \\
\hline
\end{tabular}

*A - Antes da Exposição

B - Após a Exposição

ND - Não detetado 
DISCUSSÃO 


\section{Discussão}

Com este trabalho pretendeu-se avaliar a perceção e risco de exposição ocupacional aos xilenos e tolueno pelos trabalhadores da indústria de mobiliário nas zonas de aplicação de tintas/velaturas, vernizes e tapa poros.

O trabalho foi estruturado em três fases, sendo que a primeira consistiu no desenvolvimento e na aplicação de um questionário, a segunda, na medição dos contaminantes químicos estudados no ar interior com colheita simultânea de amostras de urina em trabalhadores e a terceira, a determinação analítica dos contaminantes no ar ambiente (tolueno, etilbenzeno e xileno), bem como os seus respetivos indicadores biológicos de exposição/ contaminantes na urina. A divisão deste capítulo baseia-se nesse pressuposto.

\subsection{Análise da Perceção e Risco de Exposição}

As tintas/velaturas, vernizes e tapa poros são constituídos por xileno, tolueno e etilbenzeno, entre outras substâncias químicas perigosas, sendo preocupante o facto de os trabalhadores classificarem entre baixo e médio $o$ risco de exposição a estes produtos químicos, o que revela a falta de consciência do risco associado.

Esta falta de conhecimento sobre os químicos utilizados revela-se também quando discordam que as tintas/velaturas, vernizes e tapa poros são constituídos por xileno e tolueno.

Ao nível da exposição, aplicação e manuseamento em termos médios também respondem como havendo pouco ou médio risco.

A utilização dos meios de proteção coletiva é imprescindível na prevenção da exposição às substâncias químicas, sendo mesmo do ponto de vista legal, a medida prioritária [artigo 15ํánea j) da Lei 102/2009, de 10 de 
setembro, que aprova o regime jurídico da promoção da segurança e saúde no trabalho, e à segunda alteração ao Decreto - Lei n.ำ 116/97, de 12 de maio, que

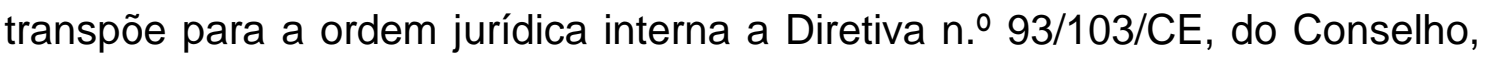
de 23 de novembro, relativa às prescrições mínimas de segurança e de saúde no trabalho a bordo dos navios de pesca, com a redação da Lei n. ${ }^{\circ}$ 3/2014 de 28 de janeiro]. Os trabalhadores utilizam as cabines de aspiração, no entanto, 25,2 \% refere que têm "sempre" a manutenção adequada e 20,1 \% a "maioria das vezes", ou seja, menos de metade dos trabalhos consideram as manutenções suficientes. Sendo a manutenção e a limpeza das cabines imprescindível ao seu bom funcionamento, esta situação revela-se preocupante, demonstrando que o empregador investiu nestes equipamentos mas os trabalhadores não estão a beneficiar da sua eficiência, estando a desperdiçar energia ao estarem a utiliza-las nestas condições, ou seja, sem rentabilizar as suas totais capacidades.

De acordo com a norma EN 14387:2004+A1:2008 os filtros adequados são os filtros de gases e vapores orgânicos de ponto de ebulição superior a 65 ${ }^{\circ} \mathrm{C}$. Durante a manipulação destes produtos e segundo as fichas de dados de segurança dos produtos utilizados devem ser utilizadas luvas de nitrilo, cumprindo as normas EN 14387:2005 (Packham C, 2006; U.S. Department of Energy Office of Science, 2005). A norma EN 14605:2005 + A1:2009 estabelece as especificações dos fatos de proteção, sendo que para a proteção contra químicos pulverizados é recomendável a utilização de fatos de proteção do tipo 4 e descartáveis (NTP 929 - Ropa de protección contra productos químicos).

Dos trabalhadores, 50,7\% indicam que usam sempre a máscara de proteção na manipulação das tintas/velaturas, vernizes e tapa poros, ou seja, metade dos trabalhadores. Acresce o facto de em termos médios não saberem quando substituir os filtros da máscara. Também 44,7\% referiram que a exposição a estes produtos Ihes provoca irritação no nariz e garganta. Ainda $65,5 \%$ dos trabalhadores mencionaram que existia um cheiro intenso a produtos químicos nos seus postos de trabalho. 
Relativamente ao uso de luvas de proteção durante as medições dos contaminantes no ar interior, registou-se que o tipo de equipamentos de proteção individual os trabalhadores estavam a utilizar, e verificou-se que a esmagadora maioria não estava a utilizar as luvas de proteção adequadas. Usavam, entre outras, luvas de látex e luvas revestidas a borracha com as costas da mão em tecido. Aproximadamente 57,7 \% concorda e 16,2 \% concorda totalmente que o empregador lhes forneceu luvas de proteção. Revelam também que usam as luvas de proteção e que o contato destes produtos com a pele é perigoso. Também, $52,2 \%$ indica que ficam com a pele seca e irritada quando não utilizam as luvas. No entanto, $57,1 \%$ dos trabalhadores concorda e 10,7 \% concorda totalmente que as luvas de proteção que thes forneceram eram as mais adequadas. Demonstrando que os trabalhadores revelam um total desconhecimento sobre o tipo de luvas de proteção mais adequados na manipulação destes produtos químicos.

Ao nível da sintomatologia é de facto preocupante quando $45 \%$ dos trabalhadores refere que já teve irritação no nariz e garganta o que comprova que inalaram estas substâncias químicas. Outra situação preocupante é o facto de $25,9 \%$ dos trabalhadores mencionarem que a exposição Ihes provoca dores de cabeça. Os trabalhadores indicam $(49,2 \%)$ que existe ruído intenso no posto de trabalho o que torna esta conjugação perigosa. Como já foi demonstrado num estudo elaborado por Morata et al., 1993 e outro por Jonhson AC., 1993, existe um efeito sinérgico entre o ruído e a exposição ao tolueno. Outro estudo, levado a cabo por Cary et al., 1997, demonstrou que os trabalhadores expostos ao tolueno sofriam de perda auditiva, na sensibilidade do limiar para tons puros, e no mínimo um dano auditivo quando expostos simultaneamente a químicos e ao ruído (Pereira, 2003).

Sensivelmente $15,7 \%$ dos trabalhadores reconhecem que ignoram algumas vezes as regras de segurança, 10,8 \% sempre e 5,7\% a maioria das vezes, no seu conjunto, representa $32,2 \%$, levando-nos a concluir que existe um problema comportamental dos trabalhadores apesar de conhecerem as regras de segurança. 


\subsection{Análise das Monitorizações Ambientais do Ar Interior}

A análise dos resultados das medições das concentrações dos COV's nas diferentes empresas, demonstrou que a média aritmética das concentrações determinadas foi de $51 \mathrm{ppm}$ para o tolueno, $23 \mathrm{ppm}$ para 0 etilbenzeno e 57 ppm para os isómeros do xileno.

Os valores encontrados são bastante superiores aos identificados num estudo realizado no Concelho de Paços de Ferreira em 2007 pela Autoridade para as Condições de Trabalho em empresas do mesmo âmbito. No qual se detetou uma concentração média do tolueno de 18,7 ppm, do etilbenzeno de 5,2 ppm e do xileno de 19,7 ppm (ACT, 2007).

A concentração máxima determinada neste estudo para o tolueno foi de 168 ppm, para o etilbenzeno foi de 56 ppm e 119 ppm para o xileno.

Os níveis encontrados foram muito superiores aos encontrados num estudo efetuado em duas fábricas de tintas na Tailândia, cujas concentrações rondam entre 0,1 e 13,1 ppm para o xileno e entre 0,5 e 48,7 ppm para o tolueno (Anamai Thetkathuek, et al., 2015).

Nas empresas estudadas, o xileno foi a substância detetada em maior abundância no ar dos postos de trabalho analisados.

No estudo efetuado sobre a Perceção ao Risco de Exposição Ocupacional ao Xileno e ao Formaldeído por Estudantes de Anatomia Patológica, Citológica e Tanatológica em 2007 (Dias-Teixeira M, 2009), onde foram encontradas concentrações entre 162,2 e 181,1 ppm para os isómeros de xileno e entre 155,3 e 196,8 para o etilbenzeno.

Os resultados obtidos nas indústrias de mobiliária foram inferiores aos detetados em laboratório. Estes resultados eram espectáveis porque em 
laboratório são utilizadas concentrações de COV,s bastante elevadas e com elevado grau de pureza enquanto no meio industrial o xileno, tolueno e etilbenzeno são substâncias químicas que compõem as tintas/velaturas, vernizes e tapa poros em concentrações muito menores.

Das medições efetuadas, 56\% das amostras analisadas encontram-se acima do VLE-MP para os isómeros de xileno estabelecido no Decreto-Lei n.ำ 24/2012, de 06 de fevereiro (50 ppm) e 8\% encontra-se acima do VLE-MP da NP 1796:2014 que é de 100 ppm. Se considerarmos os níveis de ação estabelecidos na Norma Regulamentadora 09 - Riscos Ambientais, aprovada pela Portaria MTB № 3.214, de 08 de junho de 1978 e alterada pela Portaria SSST n. ํ 25, de 29 de dezembro de 1994 (legislação brasileira) que determina como nível de ação metade do valor limite de exposição. Sensivelmente 86 \% das concentrações da média ponderada encontram-se acima do nível de ação. Ao nível das exposições de curta duração (CD) $16 \%$ das medições são

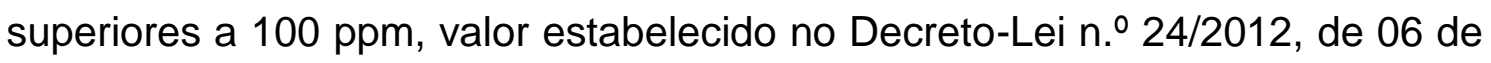
fevereiro para o VLE-CD e apenas $2 \%$ das avaliações encontram-se acima dos valores limite, isto é, 150 ppm segundo a NP 1796:2014.

Em relação ao tolueno, 39\% das medições apresentam valores de concentrações superiores ao VLE-MP, ou seja, 50 ppm, de acordo com o Decreto-Lei n. ${ }^{\circ}$ 24/2012, de 06 de fevereiro e ainda há mais $44 \%$ de locais de trabalho que apresentam concentrações superiores a 20 ppm, valor limite de exposição médio ponderado estabelecido na Norma Portuguesa 1796:2014 (NP 1796:2014). Assim, 83\% dos locais de trabalho apresentam valores de concentração de tolueno acima do estabelecido na NP 1796:2014. Comparando com o nível de ação tendo como referência os 50 ppm (DecretoLei $n$. $24 / 2012$, de 06 de fevereiro) verifica-se que $72 \%$ dos valores situam-se acima no nível de ação. Confrontando com o valor da NP 1796:2014 verifica-se que $97 \%$ das concentrações são superiores ao nível de ação. No que se refere às exposições de curta duração (CD) observa-se que 12\% das medições de 15 
minutos apresentam valores superiores ao VLE-CD, ou seja, 100 ppm estabelecido no Decreto-Lei $n . \stackrel{0}{24 / 2012}$, de 06 de fevereiro.

Relativamente ao etilbenzeno, as concentrações não apresentam nenhum valor superior ao VLE-MP, estabelecido no Decreto-Lei $n . \stackrel{0}{24 / 2012}$, de 06 de fevereiro que é de 100 ppm, no entanto, verifica-se que 56\% dos valores estão acima de 20 ppm preconizado na NP 1796:2014. Sensivelmente 92\% das concentrações estão acima do nível de ação. Quanto à comparação das concentrações determinadas, verifica-se que não há valores superiores ao VLE-CD, ou seja, 200 ppm estabelecido no Decreto-Lei n.․ 24/2012, de 06 de fevereiro.

Conhecendo os efeitos da exposição ao xileno, ao tolueno e ao etilbenzeno nos órgãos/ sistemas fisiológicos humanos, referenciados na norma NP 1796:2014 verificamos que o xileno provoca afeções auditivas, lesões nos rins e irritação do trato respiratório superior, o tolueno afeta a vista (olhos), provoca lesões no aparelho reprodutor feminino e aborto e o etilbenzeno provoca afeções auditivas, lesões nos rins e irritação do trato respiratório superior. A literatura nomeadamente na DLEP 39 - Documentación Toxicológica para el Estabelecimiento del Limite de Exposición Profissional del Tolueno (INSHT, 2007) indica que o tolueno produz efeitos no trato respiratório superior e afeta o sistema nervoso central, entre outros. Assim, considerando este efeito aditivo entre os isómeros de xileno, tolueno e etilbenzeno, presentes no ar dos locais de trabalho analisados, (figura 25), verifica-se que $92 \%$ das exposições à mistura excede o valor limite de exposição $(>1)$ e apenas $8 \%$ é inferior ao valor limite de exposição $(<1)$. A média destes valores é 2,6 tendo mesmo sido encontrados postos de trabalho onde concentração máxima da mistura foi de 5,5 , estes dados evidenciam que os trabalhadores muito provavelmente podem vir a sofrer distúrbios funcionais NP 1796:2014. 
Num estudo efetuado a 96 trabalhadores de sete empresas de tintas e de impressão, situadas em Sidoarjo na Indonésia os investigadores concluíram que apenas $5 \%$ dos trabalhadores apresentaram valores de ácido hipúrico (determinado por espectrofotometria) acima do valor limite biológico quando as concentrações de tolueno no ar do local de trabalho se situavam abaixo de 28,1 ppm (Moch Sahri and Noeroel Widajati, 2013). 


\subsection{Análise das Monitorizações dos Indicadores Biológicos de Exposição na Urina}

Os valores obtidos dos ácidos metil-hipúricos revelam que não são constituintes normais da urina (Tabela 7), revelando que existem diferenças significativas antes e após a exposição de oito horas diárias ao xileno como indicado em estudos prévios (Inoue O et al., 1993).

Nas amostras de urina recolhidas antes da exposição não se encontram indicadores biológicos de exposição. Após uma semana de jornada laboral e com 8 horas diárias de exposição, detetaram-se em média 1,6 g/g de creatinina de ácido metilhipurico, $0,3 \mathrm{~g} / \mathrm{g}$ de creatinina do somatório do ácido fenilglioxilico com o ácido mandélico, $1,9 \mathrm{~g} / \mathrm{g}$ de creatinina de ácido hipúrico e 0,3 mg/g de creatinina de o-cresol (Tabela 7).

Em 1999, foi demonstrado num estudo efetuado com 38 trabalhadores em três fábricas de tintas que para concentrações inferiores a 50 ppm de tolueno, a determinação de o-cresol na urina é mais sensível que o ácido hipúrico (Truchon G., et al, 1999).

Em Phatthalung na Tailândia foi efetuado um estudo com 87 pintores da indústria de mobiliário em aço onde foram analisadas 87 amostras de ar nos locais de trabalho, resultando uma média de concentração de 55 ppm de tolueno. A média de ácido hipúrico na urina foi de $0,8 \mathrm{~g} / \mathrm{g}$ de creatinina. Entre os trabalhadores no presente estudo, $14,9 \%$ dos pintores tinham níveis de ácido hipúrico superiores 1,6 g/g de creatinina (Somsiri Decharat, 2014).

Também na zona oriental da Tailândia foi estudado em duas fábricas de tintas a exposição dos trabalhadores ao tolueno e xileno. Entraram neste estudo 92 trabalhadores expostos. A média de concentrações de xileno presente no ar foi de 2,7 ppm e de 9,5 ppm para o tolueno. A concentração de ácido metil-hipúrico na urina dos trabalhadores foi em média de 0,78 g/g de creatinina e de $0,57 \mathrm{~g} / \mathrm{g}$ de creatinina para o ácido hipúrico (média) (Anamai Thetkathuek, et al., 2015). 
Em 2011 foi publicado um artigo sobre a avaliação dos sintomas neuropsicológicos e exposição ao benzeno, tolueno e xileno entre os dois grupos diferentes de trabalhadores de empresas de mobiliário em Izmir na Turquia. Através da determinação do benzeno, tolueno e xileno no sangue, a média das concentrações do benzeno foi de 0,11 $\pm 0,03 \mathrm{ppm}, 0,43 \pm 0,76 \mathrm{ppm}$ para $o$ tolueno e apenas um trabalhador apresentou xileno no sangue $(0,061 \mathrm{mg} / \mathrm{l})$. De acordo com as recomendações da ACGIH - American Conference of Governmental Industrial Hygienists os metabolitos do benzeno são ácido s-fenilmercaptúrico na urina e o ácido t,t-mucónico na urina, do tolueno, tolueno no sangue com um valor limite biológico de $0,02 \mathrm{mg} / \mathrm{L}$, tolueno na urina e o-Cresol na urina e para o xileno, ácidos (o, m, p)-metilhipúricos na urina. Assim, os resultados obtidos neste estudo só são comparáveis com as recomendações da ACGIH no tocante ao tolueno, e aqui, verifica-se que os resultados obtidos ultrapassam o valor limite biológico para o tolueno (Aliye Mandiracioglu A., et al., 2011).

Num estudo sobre os trabalhadores de empresas gráficas, os níveis de tolueno sangue nos grupos exposto foi $0,036 \mathrm{mg} / \mathrm{L}$ (Vrca, et al., 1996).

Também num estudo efetuado em 2005 em Hamadan no Irão com três grupos de trabalhadores, sendo eles, 60 motoristas de táxis, 25 trabalhadores de bombas de gasolina e 40 pintores automóveis, concluíram que havia uma boa correlação entre o-Cresol na urina e a exposição de tolueno quando o tolueno no ar é superior a $3 \mathrm{ppm}$ para pintores e trabalhadores de bombas de gasolina e também entre o ácido hipúrico e tolueno quando a concentração de tolueno no ar ambiente é superior a $35 \mathrm{ppm}$ (pintores) (Bahrami A., et al., 2005). O estudo de campo com 33 trabalhadores e efetuado por Angerer e Kramer mostrou que a determinação o-Cresol na urina representa um específico e sensível indicador individual de tolueno. Encontraram um coeficiente de correlação de 0,65 para uma concentração de tolueno de 65,8 ppm. Em contraste, a determinação da concentração de ácido hipúrico na urina não foi recomendada para avaliação da exposição individual (Angerer e Kramer, 1997). 
Já em 2003, foi efetuado um estudo na Turquia onde se expôs intencionalmente um grupo de trabalhadores a tolueno e comparou-se com um grupo de trabalhadores do sector do calçado. Neste estudo foi selecionado uma amostra de 54 trabalhadores do sector do calçado, tendo sido determinada em média a concentração de $0,39 \pm 0,30 \mathrm{~g} / \mathrm{g}$ de creatinina para o ácido hipúrico e de $0,084 \pm 0,045 \mathrm{mg} / \mathrm{g}$ de creatinina de o-Cresol (Çok, I., et al., 2003). 


\section{CONCLUSÕES}




\section{Conclusões}

Os trabalhadores das empresas de fabrico de mobiliário estudadas revelam uma fraca perceção do risco de exposição ao tolueno, ao etilbenzeno e ao xileno.

Face às concentrações de COVs detetadas podemos inferir que:

- $56 \%$ dos locais de trabalho estudados apresentam concentrações de xileno superiores ao VLE-MP estabelecido no Decreto-Lei n.. 24/2012, de 06 de fevereiro (50 ppm) e 8\% encontram-se acima do VLE-MP da NP 1796:2014 (100 ppm).

- $39 \%$ dos locais de trabalho estudados apresentam concentrações de tolueno superiores ao VLE-MP estabelecido no Decreto-Lei n.. 24/2012, de 06 de fevereiro (50 ppm) e 44\% encontram-se acima do VLE-MP da NP 1796:2014 (20 ppm).

Em nenhum posto de trabalho as concentrações de etilbenzeno detetadas ultrapassam o VLE-MP, estabelecido no Decreto-Lei n.․ 24/2012, de 06 de fevereiro (100 ppm), no entanto, verifica-se que 56\% dos postos de trabalho apresentam concentrações superiores ao VLE-MP preconizado na NP 1796:2014 (20 ppm).

As concentrações urinárias dos indicadores biológicos de exposição aos contaminantes químicos estudados revelam que após uma semana de jornada laboral e 8 horas diárias de exposição, os níveis médios de ácido metilhipúrico e ácido hipúrico ultrapassam os limites estipulados na NP1796:2014 e ACGIH, 2015 para o xileno e tolueno respetivamente. Todavia, para o atual indicador biológico de exposição ao tolueno, o-cresol, os níveis médios detetados encontram-se dentro do limite definido pela NP1796:2014 (0,3 mg/g de creatinina). 
Com este estudo, podemos concluir que a exposição às tintas/ velaturas, vernizes e tapa poros, constituídos entre diversas substâncias por compostos orgânicos voláteis, com maior destaque para o tolueno e o xileno sendo estas duas substâncias fatores de risco para a saúde dos trabalhadores do fabrico de móveis. 
BIBLIOGRAFIA 
Bibliografia 


\section{Bibliografia}

Amorim LC, \& Alvarez-Leite EM. (1997). Determination of o-cresol by gas chromatography and comparison with hippuric acid levels in urine samples of individuals exposed to toluene. Journal of Toxicology and Environmental Health, 50, 401-407.

Agencia para Sustancias Tóxicas y el Registro de Enfermedades. (ATSDR). 1999. Reseña Toxicológica del Etilbenceno (en inglés). Atlanta, GA: Departamento de Salud y Servicios Humanos de los EE.UU., Servicio de Salud Pública.

Agency for Toxic Substances and Disease Registry (ATSDR). (2000). Toluene Toxicity Physiologic Effects ATSDR-CHEM.

Agency for Toxic Substances and Disease Registry (ATSDR). 2007. Toxicological Profile for Xylene. U.S. Department of Health and Human Services, Public Health Service, Atlanta.

Agency for Toxic Sustances and Disease Registry (ATSDR). (2007). Benzene. ATSDR minimal risk levels (MRLS). Atlanta, Public Health Service.

American Conference of Governmental Industrial Hygienists - ACGIH (2014) TLV's and BEl's Based on the Documentation of the Threshold Limit Values for Chemical Substances and Physical Agents \& Biological Exposure Indices.

Anderson, K., Fuxe, K., Pilsen, O.G., Toftgård, R., Eneroth, P. and Gustafsson, J-Å. (1981). Production of discrete changes in dopamine and noradrenaline levels and turnover in various parts of the rat brain following exposure to xylene, ortho-, meta-, and para-xylene, and ethylbenzene. Toxicology and Applied Pharmacology, 60, 535-548.

Angerer, J. and A. Kramer (1997). Occupational chronic exposure to organic solvents. XVI. Ambient and biological monitoring of workers exposed to 
toluene. Archive Occupational Environmental Health. 1997;69(2):91-6. Retrieved 26 $6^{\text {th }}$ of September, 2015, from http://www.ncbi.nlm.nih.gov/pubmed/9001914

Astrand, I., Engström, J. and Ovrum, P. (1978). Exposure to xylene and ethylbenzene. I. Uptake, distribution and elimination in man. Scandinavian Jornal Work Environment \& Health. September 4(3):18594.

Bahrami, A., Jonidi-Jafari, A., Folladi, B., Mahjub, H., Sadri, Q. and Zadeh, M. M. (2005). Comparison ok urinary o-Cresol ah hippuric acid in drivers, gasoline station workers and painters exposed to toluene in west of Iran. Pakistan Journal of Biological Sciences 8 (7): 1001-1005. Retrieved $26^{\text {th }}$ of September, 2015, from http://www.researchgate.net/publication/258234422 Comparison of urin ary Ocresol and hippuric acid in drivers gasoline station workers a nd painters exposed to toluene in west of iran

Baird, C. (1995). Environmental chemistry. New York, EUA: Ed. W.H. Freeman and CO.

Bardodej, Z., Bardodejova, E. (1970). Biotransformation of Ethyl Benzene, Styrene and alpha-Methylstyrene in Man. American Industrial Hygiene Associational Jornal, March-April; 31, 206-209.

Beasley, M. (1992). Xylene. University of Otago Medical School. New Zealand.

Becher, R., Hongslo, J.K., Jantunen, M.J., Dybing, (1999). E. Environmental chemicals relevant for respiratory hypersensitivity: the indoor environment. Toxicology Letters: № 86 p.155-162.

Belli Filho, P., De Melo Lisboa, H. (1998). Avaliação de emissões odorantes. Revista de Engenharia Sanitária e Ambiental. Ed. ABES: vol.3. ㄲo 3 Jul/Set e no 4 Out-Dez.

Bethwaite, P.B., Pearce, N., Fraser, J. (1990). Cancer risks in painters: study based on the New Zealand Cancer Registry. British Journal of Industrial 
Medicine 1990;47:742-746. Retrieved $23^{\text {th }}$ of Setpember, 2015, from http://www.ncbi.nlm.nih.gov/pubmed/2245185

Bobev, G., Koen, E. (1976). Sanitary chemical evaluation and control of hazards in the varnishing ships of the furniture industry. 2:63-70. Bulgarian. Consultado em $06^{\text {th }}$ de October 2015 e disponivel em http://www.ncbi.nlm.nih.gov/pubmed/1032723

Bosia, J. (2005). Afectación Hepática en Trabajadores de una Industria Petroquímica. Consultado em $19^{\text {th }}$ de September 2015 e disponivel em: http://www.postgradofcm.edu.ar/ProduccionCientifica/TesisDoctorales/3. $\underline{\mathrm{pdf}}$

Brickus, L.S.R.; Aquino Neto, F.R. (1999). A qualidade do ar de interiores e a química. Química Nova: vol.22, ㄲo1, p.65-74.

Browning, E., Snyder, R. ; Buhler, D. R. ; Thurman, Ronald, G. (1987). Toxicity and Metabolism of Industrial Solvents. Amsterdam:Elsevier

Campos, C., Santos, P. (2010) Factores que determinam a qualidade do ar interior. In Arezes P., Baptista, J.S., Barroso, M.P., Carneiro, P., Cordeiro, P., Costa, N., Melo, R., Miguel, A.S., Perestrelo, G.P. (eds). Segurança e Higiene Ocupacionais - SHO (pp.138-142). Guimarães, Portugal: Sociedade Portuguesa de Segurança e Higiene Ocupacionais.

Cappaert, N., Klis, S., Baretta, A., Muijser, H. \& Smoorenburg, G. (2000). Ethylbenzene-induced ototoxicity in rats: a dose-dependent midfrequency hearing loss. Journal of Association for Research in Otolaryngology, 1(4), 292-299.

Cappaert, N., Klis, S., Muijser, H., Kulig, B., Ravensberg, L. \& Smoorenburg, G. (2002). Differential susceptibility of rats and guinea pigs to the ototoxic effects of ethylbenzene. Neurotoxicol Teratol, 24(4) , 503-510.

Carmo, A.T., Prado, R.T.A. (1999). Qualidade do ar interno. Texto Técnico. São Paulo: Escola Politécnica da Universidade de São Paulo: Departamento de Engenharia de Construção Civil. 
Cassaret, Luis and Doull, James (2001). Toxycology: The Basic Science of Poisons. 6 ed. McGraw-Hill, New York.

Çok, I., Dagdelen, A., Gokçe, E. (2003). Determination of urinary hippuric acid and o-cresol levels as biological indicators of toluene exposure in shoeworkers and glue sniffers. Biomarkers, volume 8 number 2 (March/April 2003), 119/127. Retrieved $30^{\text {th }}$ of Setpember, 2015, from http://www.ncbi.nlm.nih.gov/pubmed/12775497

Croute, F., Poinsot, J., Gaubin, Y., Beau, B., Simon, V., Murat, J.C., Soleilhavoup J.P. (2002). Volatile organic compounds cytotoxicity and expression of HSP72, HSP90 and GRP78 stress proteins in cultured cells. Biochimica et Biophysica Acta 2002; 1591: 147-155.

David, E., Hartman. (2000). Identification and Assessment of Human Neurotoxic Syndromes. Neuropsychological Toxicology. Second Edition.; 149-224.

De Ceaurriz, J.C., Micillino, J.A., Bonnet, P. and Guenier, J.P. (1981). Sensory irritation caused by various industrial airborne chemicals. Toxicology Letters, 9, 137-143.

Decharat, S. (2014). Hippuric Acid Levels in Paint Workers at Steel Furniture Manufacturers in Thailand. Safety and Health at Work 5 (2014) 227 e 233. Retrieved $23^{\text {th }}$ of Setpember, 2015,from http://www.ncbi.nlm.nih.gov/pubmed/?term=Hippuric+Acid+Levels+in+Pa int+Workers+at+Steel+Furniture+Manufacturers+in+Thailand

Dewulf, J., Langenhove, H.V., Wittmann, G. (2002). Analysis of volatile organic compounds using gas chromatography. Trends In Analytical Chemistry: Vol. 21, p.637-646.

Dias-Teixeira A, Dias-Teixeira M, Rangel R, Tiritan E, Gonçalves, V., \& Domingues V. (2010). Development and validation of HPLC-DAD method for the simultaneous determination of creatinine and metabolites of xylene, toluene and ethylbenzene in urine. Paper presented at the SETAC EUROPE: 20TH ANNUAL MEETING, Seville. 
Donald-James, M., Hooper, K. y Hopenhayn-Rich, C., (1991). Reproductive and Developmental Toxicity of Toluene. Journal Environmental Health Perspectives, 94:237-244 California. Retrieved 20 th of September, 2015, from http://www.ncbi.nlm.nih.gov/pmc/articles/PMC1567945/

Dumas, S., Parent, M.E., Siemiatycki, J., Brisson, J. (2000). Rectal cancer and occupational risk factors: a hypothesis-generating, exposure-based casecontrol study. International Jornal of Cancer. 2000 Sep 15;87(6):874-9. Retrieved $27^{\text {th }}$ of September, 2015, from http://www.ncbi.nlm.nih.gov/pubmed/10956400

Dutkiewicz, T., Tyras, H. (1967). A Study of the Skin Absorption of Ethyl Benzene in Man. British Journal of Industrial Medicine, 1967 (4): October 24 , 330-332. Retrieved $27^{\text {th }}$ of September, 2015, from http://www.ncbi.nlm.nih.gov/pmc/articles/PMC1008629/

Engström, K., Husman, K. and Riihimäki, V. (1977). Percutaneous absorption of $\mathrm{m}$-xylene in man. International Archives of Occupational and Environmental Health. 1977 August 31;39(3):181-9.

Farrell, G. Drugs and steatohepatitis. Semin Liver Dis 2002; 22: 185-94. Consultado em 19 th $^{\text {th }}$ de September 2015 e disponivel em: http://www.ncbi.nlm.nih.gov/sites/entrez

Gioda, A. , Aquino Neto, F.R. (2003). Poluição química relacionada ao ar de interiores no Brasil. Química Nova: vol. 26, p. 359-365.

Godish, T. (1991) Air Quality. 2ª Ed: Lewis Publishers.

Gromiec, J.P., Piotrowski, J.K. (1984). Urinary Mandelic Acid as an Exposure Test for Ethyl Benzene. International Archives of Occupational and Environmental Health, 55, 61-72.

Hardell, L., Eriksson, M., Lenner, P., Lundgren, E. (1981). Malignant lymphoma and exposure to chemicals, especially organic solvents, chlorophenols and phenoxy acids: a case-control study. British Jornal of Cancer. 1981 
February;43(2):169-76. Retrieved $27^{\text {th }}$ of September, 2015, from http://www.ncbi.nlm.nih.gov/pubmed/7470379

Horowitz, R. (2001). Aromatic Hydrocarbons Chap 99 In Clinical Toxicology. 802-812. (Ford M; Delaney, K, Ling L; Erickson T Eds). W.B Saunders. Philadelphia.

Instituto Português da Qualidade (IPQ). (2014). Segurança e saúde do trabalho. Valores-limite e índices biológicos de exposição profissional a agentes químicos, (Vol. NP 1796): Instituto Português da Qualidade.

International Agency for Research on Cancer, IARC. (1999)a. Summary of Data Reported and Evaluation, Toluene. Vol. 71:829.

IPCS - International Programme on Chemical Safety - Principles for the assessment of risks to human health from exposure to chemicals. Geneva: WHO, 1999. - XX (Environmental Health Criteria; 210).

Irwin, RJ., VanMouwerick, M., Stevens, L., Seese, MD., Basham, W. (1997). Environmental Contaminants Encyclopedia. National Park Service, Water Resouces Division, Fort Collins, Colorado.

Ivanov, S.V. (1964). Data on Toxicology and Hygienic Rating of Ethylbenzene in the Atmosphere of Industrial Buildings. Gig. Tr. Prof. Zabol., 2, 9-14.

J. Donald Millar, M.D., D.T.P.H (1987). Organic solvent neurotoxicity. Current intelligence bulletin $48, \mathrm{NIOSH}$.

Javier, G.V.; Lourdes, R.G.M.; Georgina, O.M.M.; Gabriela, H.P.; Aurora, R.A. (2003). Estudio de calidad del aire interior y su influencia sobre Quejas / síntomas relacionados con el "Síndrome del Edifício Enfermo" entre ocupantes del edificio cultural y administrativo de la Universidad de Guadalajara, Jalisco, México In: III Congresso Interamericano de Qualidade do Ar da AIDIS. Canoas.

Jean Q. Xiao, (2000). The Diagnosis and Management of Solvent-Related Disorders. American Journal of Industrial Medicine; 37:44-61. Retrieved $27^{\text {th }}$ of September, 2015 , from 
http://www.ncbi.nlm.nih.gov/pubmed/?term=The+Diagnosis+and+Manag ement+of+Solvent-Related+Disorders

Junqueira, CL., Carneiro, J. (2004). Histologia Básica. 10. ed. Rio de Janeiro:Guanabara Koogan.

Kalabokas, P.D., Hatzianestis, J., Bartzis, J.G., Papagiannakopoulos, P. (2001) Atmospheric concentrations of saturated and aromatic hydrocarbons around a Greek oil refinery. Atmospheric Environmental: ํㅜ 35, p. 25452555.

Langman, J. M.,(1994). Xylene: its toxicity, measurement of exposure levels, absorption, metabolism and clearance. Oxford Journal Pathology, 26:301 Australia. Retrieved $20^{\text {th }}$ of September, 2015, from http://www.ncbi.nlm.nih.gov/pubmed/7991289

Lauwerys, R. (1994). Toxicología industrial e intoxicaciones profesionales. $3^{\circ}$ ed. Ed Masson.p. 3-9.

Lewis, Robert. Lewis (1998). Dictionary Toxicology. 1 ed. Lewis Publisher, New York, 1998, p.p.152,153, 476,1038, 1039, 1118, 1119.

Mandiracioglu, A., Akgur, S., Kocabiyik, N., Sener, U. (2011). Evaluation of neuropsychological symptoms and exposure to benzene, toluene and xylene among two different furniture worker groups in Izmir. Toxicology and Industrial Health 27(9) 802-809. Retrieved $26^{\text {th }}$ of September, 2015, from http://www.ncbi.nlm.nih.gov/pubmed/21421681

Mayan,O, Gonçalves, I, Trigo, L, Neves, P, Gonçalves, C, Guimarães, F., Rodrigues, S., Martins, M. (2011). Condições de trabalho na indústria de mobiliário de madeira. Lisboa. Autoridade para as condições do trabalho.

Merck \& CO. (1995). The Merck index: an Encyclopedia of chemicals, drugs and biologicals. New Jersey: Whitehouse Station.

Miguel, A.S. (2006). Manual de Higiene e segurança do trabalho (9 Edição). Porto: Porto Editora. 
Miller, B.A., Blair, A.E., Raynor, H.L., Stewart, P.A., Zahm, S.H., Fraumeni, J.F., Jr. (1989). Cancer and other mortality patterns among United States furniture workers. Brithis Jornal Industrial Medicine. 1989 August; 46(8): 508-15. Retrieved $27^{\text {th }}$ of September, 2015,from http://www.ncbi.nlm.nih.gov/pubmed/?term=Cancer+and+other+mortality +patterns+among+United+States+furniture+workers

Moreno Gray, M. D. (2003). Toxicología ambiental. Evaluación del Riesgo para la Salud Humana. Mc. Graw Hill. / Interamericana de España S.A.U.

Morley, R., Eccleston, DW., Douglas, CP., Greville, WEJ.,.Anderson, J., Scott, DJ. (1970). Xylene poisoning - a report on one fatal case and two cases of recovery after prolonged unconsciousness. British Medical Jornal; 442-443. Retrieved $27^{\text {th }}$ of September, 2015, from http://www.ncbi.nlm.nih.gov/pubmed/?term=Xylene+poisoning+\%E2\%80 $\% 93+$ a+report+on+one+fatal+case+and+two+cases+of+recovery+after+ prolonged+unconsciousness

Motock GT, Perkins JB, \& Reynolds JM. (2003). Hippuric and methyl hippuric acids in urine: Method 8301 . Manual of Analytical Methods.

Ogata, M., Tomokuni, K. y Takatsuka, Y. (1970). Urinary excretion of hippuric acid and $\mathrm{m}$ - or $\mathrm{p}$-methylhippuric acid in the urine of persons exposed to vapours of toluene and $\mathrm{m}$ - or $\mathrm{p}$-xylene as a test of exposure. British Jornal of Industrial Medicine 27(1):43-50. Retrieved 20 th of September, 2015, from http://oem.bmj.com/cgi/content/abstract/27/1/43

Pendergrass SM. (2003). Hydrocarbons, Aromatic: Method 1501. Manual of Analytical Methods.

Prista, J., Uva, A.S. (2002). Aspectos Gerais de Toxicologia para Médicos do Trabalho. ENSP.UNL, (Obras Avulsas, 6).

Randal, Craig and Creavey, Robert. (2002). Disposition of toxic drugs and chemicals in man. 6 ed. Book Medical Publisher, Chicago, p.p. 96-98, 404-405, 1041-1045, 1099-1181. 
Rego, MA. (1999). Reflexões sobre o Câncer Ocupacional. Sociedade Bahiana de Medicina do Trabalho.

Riihimäki, V. y Pfäffli, P. (1978). Percutaneous absorption of solvent vapors in man. Jornal Work Environmental Health 4 (1) 73-85. Retrieved $20^{\text {th }}$ of September, 2015, from http://www.ncbi.nlm.nih.gov/pubmed/?term=Percutaneous+absorption+of +solvent+vapors+in+man

Riihimäki, V., Savolainen, K., Pfäffli, P., Pekari, K., Sippel, HW., Laine, A. (1982a). Metabolic Interaction Between $\mathrm{m}$ - Xylene and Ethanol. Archive Toxicology; 49: 253-263. Retrieved 27th of September, 2015, from http://www.ncbi.nlm.nih.gov/pubmed/7092564

Rodríguez, M., Squillante, G. y Rojas, M. (2003). Exposición ocupacional a solventes orgánicos en una fábrica de calzado en Valencia. Venezuela. Gaceta Médica de Caracas; 111(4):294-301.

Ruth, J.H. (1986). Odour thresholds and irritation levels of several chemical substances: A review. American Industrial Hygiene Association Journal, 47, A142-A151.

Sahrim, M., Widajatin N. (2013). Evaluation of Toluene Exposure in Workers at Industrial Area of Sidoarjo, Indonesia by Measurement of Urinary Hippuric Acid. Asia Pacific Journal of Medical Toxicology. Department of Occupational Health and Safety, Department of Public Health, Airlangga University, Surabaya, Indonesia; 2013, 2:145-9.

Savolainen, K., Riihimäki, V., Linnoila, M. (1979). Effects of short-term xylene exposure on psychophysiological functions in man. International Archives of Occupational Environmental Health 1979; 44 :201- 211.

Sedivec, V., Flek, J. (1976). The absorption, metabolism, and excretion of xylenes in man. Int. Archive Occupational Environmental Health 37(3):205-217. Retrieved 20 2 th of September, 2015, from http://www.springerlink.com/content/m105116010221817/ 
Sistema Nervioso. Neurotoxicidad. Enciclopedia OIT 2001; 7.

SPSS Inc. (2012). IBM SPSS Statistics Release 21.0.1 for Windows.

Streicher, HZ., Gabow, PA., Moss, AH., Kono, WD. (1981). Syndromes of Tolueno Sniffing in Adults. Annals of internal Medicine: 758-762.

Stellman, J. M., Osinsky, D. y Markkanen, P. (2001). Enciclopedia de Salud y Seguridad en el Trabajo, OIT. Propiedades De Los Hidrocarburos Aromáticos. p.p. 104.282-.285.

Suneson, A.L. Nilsson, C.A., Andersson, B. (1995). Evaluation of adsorbents for sampling and quantitative analysis of microbial volatiles using thermal desorption-gas chromatography. Journal of Chromatography A: № 699, pp.203-214.

Thetkathuek, A., Jaidee, W.,Saowakhontha, S., Ekburanawat, W. (2015). Neuropsychological Symptoms among Workers Exposed to Toluene and Xylene in Two Paint Manufacturing Factories in Eastern Thailand. Hindawi Publishing Corporation Advances in Preventive Medicine Volume 2015, Article ID 183728. Retrieved 26 th of September, 2015, from http://www.hindawi.com/journals/apm/2015/183728/

Tiburtius, ERL., Zamora, PP., Lea, LES. (2004). Contaminação de águas por BTXs e processos utilizados na remediação de sítios contaminados. Química Nova; 27(3):441-446.

Torres, C. y col. (2006). Evaluación del Daño en el ADN y Monitoreo Biológico de la Exposición Laboral a Solventes Orgánicos. Revista Biomédica Vol. 28, N. 001. Bogotá, Colombia.

Truchon, G., Tardif, R., Brodeur, J. (1999). O-cresol: a good indicator of exposure to low levels of toluene. Occupational Environmental Hygiene;14(10):677-81. Retrieved $23^{\text {th }}$ of September, 2015, from http://www.ncbi.nlm.nih.gov/pubmed/10561878

Trujillo, F., Dang, D., Starck, T. (2003). Xylene Keratopathy: A Case Report and Review of the literature. Cornea; 22 (I): 88-90. 
Vianna, N.J., Polan, A. (1979). Lymphomas and occupational benzene exposure. Lancet, London, England, 1979 June 30;1(8131):1394-5. Retrieved $27^{\text {th }}$ of September, 2015, from http://www.ncbi.nlm.nih.gov/pubmed/?term=Lymphomas+and+occupatio nal+benzene+exposure.+Vianna+NJ\%2C+Polan+A.

Vrca, A., Karatic, V., Bofitevic, D., et al. (1996). Brainstem auditory evoked potentials in individuals exposed to long-term low concentrations of toluene. American Journal of Industrial Medicine 30: 62-66. Retrieved $26^{\text {th }}$ of September, 2015, from http://www.ncbi.nlm.nih.gov/pubmed/8837684

Vyskocil, A., Leroux, T., Truchon, G., Gendron, I., Lemay, F., Gagnon, F., Botez, S., El Majidi, N., Émod, C. \& Viau, C. (2008b). Ethyl benzene should be considered ototoxic at occupationally relevant exposure concentrations. Toxicology and Industrial Health, 24(4), 241-246.

Wilkosky, T.C., Checkoway, H., Marshall, E.G., Tyroler, H.A. (1984). Cancer mortality and solvent exposures in the rubber industry. American Industrial Hygiene Association Jornal 1984;45:809-11. Retrieved $27^{\text {th }}$ of September, 2015, from http://www.ncbi.nlm.nih.gov/pubmed/6549104

World Health Organization (WHO), (1985). Toluene. Environmental Health Criteria, No.52. Geneva.

Yant, W.P., Schrenk, H.H., Waite, C.P. and Patty, F.A. (1930). Acute response of guinea pigs to vapours of some new commercial organic compounds. II. Ehtylbenzene. Public Health Reports, 45, 1241-1250. 


\section{ANEXOS}

\subsection{QUESTIONÁRIO DE INVESTIGAÇÃO}

Processo №
Data:

Empresa:

Tipo de produção: $\quad$ Cabine de aplicação de tintas, vernizes e tapa poros
Lixagem
Apoio
Outro
Qual?

OBJECTIVO: Realização de uma investigação científica (Tese de Doutoramento), cuja finalidade é determinar a percepção da exposição ao xileno e tolueno na indústria de mobiliário.

\section{ASSINALE SOMENTE UMA OPÇÃO.}

SE NÃO SABE RESPONDER OU NÃO TEM UMA OPINIÃO FORMADA FACE AS QUESTÕES COLOCADAS ASSINALE POR FAVOR A OPÇÃO: SEM OPINIÃO.

SE A PERGUNTA NÃO SE APLICAR AO SEU TRABALHO ASSINALE POR FAVOR: NÃO APLICÁVEL. NAS QUESTÕES QUE SE SEGUEM COLOQUE UM CIRCULO ( 0 ) À VOLTA DO NÚMERO CORRESPONDENTE À SUA RESPOSTA.

\begin{tabular}{|c|c|c|c|c|}
\hline \multicolumn{5}{|c|}{ CARACTERIZAÇÃO DO TRABALHADOR } \\
\hline Sexo & Idade & & & \\
\hline \multirow[t]{2}{*}{$\begin{array}{l}\text { Habilitações } \\
\text { literárias: }\end{array}$} & $\begin{array}{l}O 1^{\circ} \text { ciclo } \\
\left.\quad 4^{a} \text { classe }\right)\end{array}$ & $0^{20}$ ciclo ( $6^{\circ}$ ano $)$ & O $3^{\circ}$ ciclo $\left(9^{\circ}\right.$ & \\
\hline & $\begin{array}{l}\text { O Secundário } \\
\text { (12º ano) }\end{array}$ & O Licenciatura & O Mestrado & O Doutoramento \\
\hline $\begin{array}{l}\text { Último ano } \\
\text { concluído: }\end{array}$ & & & & \\
\hline
\end{tabular}




\begin{tabular}{|lcc|c|c|c|c|c|c|}
\hline $\begin{array}{c}\text { 1 } \\
\text { associado } \\
\text { produtos químicos: }\end{array}$ & $\begin{array}{c}\text { risco } \\
\text { seguintes }\end{array}$ & $\begin{array}{c}\text { Não } \\
\text { aplicável }\end{array}$ & $\begin{array}{c}\text { Sem } \\
\text { opinião }\end{array}$ & $\begin{array}{c}\text { Nenhum } \\
\text { Risco }\end{array}$ & $\begin{array}{c}\text { Pouco } \\
\text { Risco }\end{array}$ & $\begin{array}{c}\text { Medio } \\
\text { Risco }\end{array}$ & $\begin{array}{c}\text { Muito } \\
\text { Risco }\end{array}$ & $\begin{array}{c}\text { Elevadíssimo } \\
\text { Risco }\end{array}$ \\
\hline a) Ácido clorídrico & 0 & 1 & 2 & 3 & 4 & 5 & 6 \\
\hline b) Soda cáustica & 0 & 1 & 2 & 3 & 4 & 5 & 6 \\
\hline c) Tintas/velaturas da madeira & 0 & 1 & 2 & 3 & 4 & 5 & 6 \\
\hline d) Lubrificantes & 0 & 1 & 2 & 3 & 4 & 5 & 6 \\
\hline e) Detergentes & 0 & 1 & 2 & 3 & 4 & 5 & 6 \\
\hline f) Vernizes & 0 & 1 & 2 & 3 & 4 & 5 & 6 \\
\hline g) Tapa poros & 0 & 1 & 2 & 3 & 4 & 5 & 6 \\
\hline h) Xileno & 0 & 1 & 2 & 3 & 4 & 5 & 6 \\
\hline i) Tolueno & 0 & 1 & 2 & 3 & 4 & 5 & 6 \\
\hline j) Diluente & 0 & 1 & 2 & 3 & 4 & 5 & 6 \\
\hline
\end{tabular}

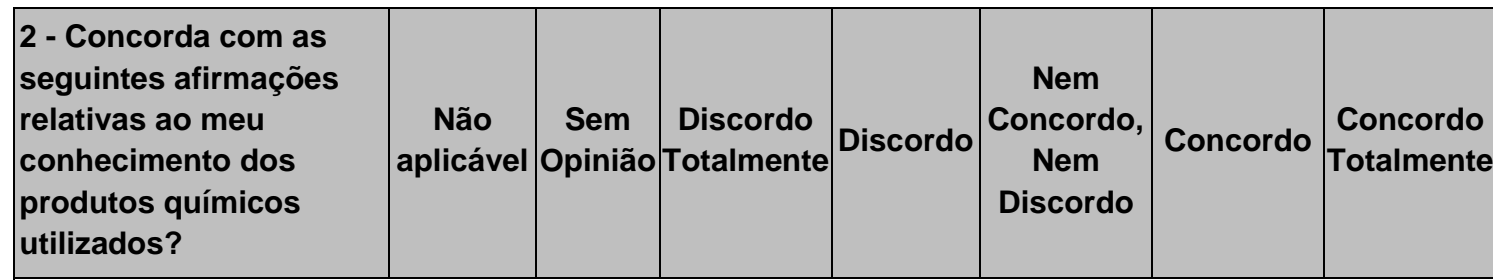

a) Sei distinguir as
tintas/velaturas, vernizes
01
2
3
4
5
6

e tapa poros

b) Já li as fichas de dados

de segurança dos

produtos químicos que

$\begin{array}{ll}0 & 1\end{array}$

2

3

4

5

6 utilizo

c) O xileno e o tolueno são substâncias químicas que compõem as 0

1

2

3

4

5

6 tintas/velaturas, vernizes e tapa poros

d) As tintas/velaturas, vernizes e tapa poros que utilizo são de base

0

1

2

3

4

5

6 solvente

e) As tintas/velaturas, vernizes e tapa poros que utilizo de base solvente têm os mesmos riscos se forem de base aquosa

$\begin{array}{lllllll}0 & 1 & 2 & 3 & 4 & 5 & 6\end{array}$




\begin{tabular}{|c|c|c|c|c|c|c|c|}
\hline 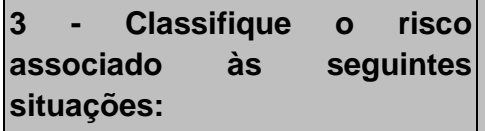 & $\begin{array}{c}\text { Não } \\
\text { aplicável }\end{array}$ & $\begin{array}{c}\text { Sem } \\
\text { opinião }\end{array}$ & $\begin{array}{c}\text { Nenhum } \\
\text { Risco }\end{array}$ & $\begin{array}{l}\text { Pouco } \\
\text { Risco }\end{array}$ & $\begin{array}{l}\text { Medio } \\
\text { Risco }\end{array}$ & $\begin{array}{l}\text { Muito } \\
\text { Risco }\end{array}$ & $\begin{array}{c}\text { Elevadíssimo } \\
\text { Risco }\end{array}$ \\
\hline a) Exposição às tintas/velaturas & 0 & 1 & 2 & 3 & 4 & 5 & 6 \\
\hline b) Exposição ao tapa poros & 0 & 1 & 2 & 3 & 4 & 5 & 6 \\
\hline c) Exposição aos vernizes & 0 & 1 & 2 & 3 & 4 & 5 & 6 \\
\hline d) Exposição aos diluentes & 0 & 1 & 2 & 3 & 4 & 5 & 6 \\
\hline e) Exposição a lubrificantes & 0 & 1 & 2 & 3 & 4 & 5 & 6 \\
\hline $\begin{array}{l}\text { f) Aplicação das tintas/velaturas, } \\
\text { tapa poros e vernizes }\end{array}$ & 0 & 1 & 2 & 3 & 4 & 5 & 6 \\
\hline $\begin{array}{l}\text { g) Diluição das tintas/velaturas, } \\
\text { tapa poros e vernizes }\end{array}$ & 0 & 1 & 2 & 3 & 4 & 5 & 6 \\
\hline $\begin{array}{l}\text { h) Aplicação das tintas/velaturas, } \\
\text { tapa poros e vernizes com as } \\
\text { cabines desligadas }\end{array}$ & 0 & 1 & 2 & 3 & 4 & 5 & 6 \\
\hline $\begin{array}{l}\text { i) Aplicação das tintas/velaturas, } \\
\text { tapa poros e vernizes fora das } \\
\text { cabines }\end{array}$ & 0 & 1 & 2 & 3 & 4 & 5 & 6 \\
\hline $\begin{array}{l}\text { j) Proximidade da estufa de } \\
\text { secagem }\end{array}$ & 0 & 1 & 2 & 3 & 4 & 5 & 6 \\
\hline $\begin{array}{l}\text { k) Manusear tintas/velaturas, } \\
\text { tapa poros e vernizes sem luvas }\end{array}$ & 0 & 1 & 2 & 3 & 4 & 5 & 6 \\
\hline $\begin{array}{l}\text { I) Manusear tintas/velaturas, tapa } \\
\text { poros e vernizes sem máscara }\end{array}$ & 0 & 1 & 2 & 3 & 4 & 5 & 6 \\
\hline $\begin{array}{l}\text { m) Não usar Equipamentos de } \\
\text { Proteção Individual (EPI's) na } \\
\text { aplicação das tintas/velaturas, } \\
\text { tapa poros e vernizes }\end{array}$ & 0 & 1 & 2 & 3 & 4 & 5 & 6 \\
\hline
\end{tabular}

\begin{tabular}{|c|c|c|c|c|c|c|c|}
\hline $\begin{array}{l}4 \text { - Concorda com as } \\
\text { seguintes afirmações } \\
\text { relativas à perceção de } \\
\text { risco às } \\
\text { tintas/velaturas, } \\
\text { vernizes e tapa poros? }\end{array}$ & $\begin{array}{c}\text { Não } \\
\text { aplicável }\end{array}$ & $\begin{array}{c}\text { Sem } \\
\text { Opinião }\end{array}$ & $\begin{array}{c}\text { Discordo } \\
\text { Totalmente }\end{array}$ & Discordo & $\begin{array}{c}\text { Nem } \\
\text { Concordo, } \\
\text { Nem } \\
\text { Discordo }\end{array}$ & Concordo & $\begin{array}{l}\text { Concordo } \\
\text { Totalmente }\end{array}$ \\
\hline $\begin{array}{l}\text { a) A exposição aos } \\
\text { gases/vapores das } \\
\text { tintas/velaturas pode ser } \\
\text { perigosa }\end{array}$ & 0 & 1 & 2 & 3 & 4 & 5 & 6 \\
\hline $\begin{array}{l}\text { b) A exposição aos } \\
\text { gases/vapores dos } \\
\text { vernizes pode ser } \\
\text { perigosa }\end{array}$ & 0 & 1 & 2 & 3 & 4 & 5 & 6 \\
\hline $\begin{array}{l}\text { c) A exposição aos } \\
\text { gases/vapores do tapa } \\
\text { poros pode ser perigosa }\end{array}$ & 0 & 1 & 2 & 3 & 4 & 5 & 6 \\
\hline
\end{tabular}


d) A exposição aos gases/vapores das tintas/velaturas é

$0 \quad 1$

2

3

4

5

6

perigosa

e) A exposição aos gases/vapores dos vernizes é perigosa

f) A exposição aos gases/vapores do tap poros é perigosa

g) Não existe risco se a exposição for por pouco tempo

h) A exposição a estes produtos pode provocar doenças

i) A exposição a estes produtos não provoca danos para a saúde

$\begin{array}{lllllll}0 & 1 & 2 & 3 & 4 & 5 & 6\end{array}$

$\begin{array}{lllllll}0 & 1 & 2 & 3 & 4 & 5 & 6\end{array}$

-

$\begin{array}{lllllll}0 & 1 & 2 & 3 & 4 & 5 & 6\end{array}$

$\begin{array}{llll}0 & 1 & 2 & 3\end{array}$

$4 \quad 5 \quad 6$

6

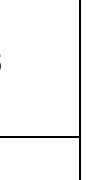

6

(2)

$\begin{array}{llllllll}0 & 1 & 2 & 3 & 4 & 5 & 6\end{array}$

\begin{tabular}{|c|c|c|c|c|c|c|c|}
\hline $\begin{array}{l}5 \text { - Concorda com as } \\
\text { seguintes afirmações } \\
\text { relativas aos } \\
\text { equipamentos de } \\
\text { proteção individual? }\end{array}$ & $\begin{array}{c}\text { Não } \\
\text { aplicável }\end{array}$ & $\begin{array}{c}\text { Sem } \\
\text { Opinião }\end{array}$ & $\begin{array}{c}\text { Discordo } \\
\text { Totalmente }\end{array}$ & Discordo & $\begin{array}{c}\text { Nem } \\
\text { Concordo, } \\
\text { Nem } \\
\text { Discordo }\end{array}$ & Concordo & $\begin{array}{l}\text { Concordo } \\
\text { Totalmente }\end{array}$ \\
\hline
\end{tabular}

a) Os meus colegas acham que não é

$\begin{array}{llllllll}\text { necessário usar máscara } & 0 & 1 & 2 & 3 & 4 & 5 & 6 \\ \text { na manipulação de } & & & & & \end{array}$

tintas/velaturas

b) Os meus colegas acham que não é

$\begin{array}{llllllll}\begin{array}{l}\text { necessário usar máscara } \\ \text { na manipulação do tapa }\end{array} & 0 & 1 & 2 & 3 & 4 & 5 & 6\end{array}$
poros

c) Os meus colegas acham que não é

$\begin{array}{llllllll}\begin{array}{l}\text { necessário usar máscara } \\ \text { na manipulação de }\end{array} & 0 & 1 & 2 & 3 & 4 & 5 & 6\end{array}$

vernizes 
d) Deram-me máscara de proteção respiratória para a manipulação de 0

3

4

5

6

tintas/velaturas, vernizes

e tapa poros

e) Penso que as

máscaras que me deram

$0 \quad 1$

3

6 são as mais adequadas

f) Sei utilizar a máscara corretamente

0

12

23

4

6

g) As máscaras para gases e vapores são as mais adequadas para a manipulação de

$0 \quad 1$

23

4

5

6

tintas/velaturas, vernizes

e tapa poros

h) Sei quando tenho de substituir os filtros da

minha máscara

i) Sei como fazer a

manutenção/limpeza da

minha máscara

j) Por vezes a minha máscara fica estragada

01

2

3

4

5

6

k) Quando a minha máscara está danificada

substituo-a

$0 \quad 1$

2

3

4

5

6

imediatamente

I) Preciso saber mais para

utilizar corretamente a

máscara

m) Quando a minha máscara está estragada espero que termine o

0

2

3

4

4

5

6

trabalho para a substituir

n) Sei quantas vezes posso usar o filtro da minha máscara

o) Utilizo a máscara que estiver disponível

$0 \quad 1$

2

2

3

4

5

6

5

p) Sei distinguir os vários tipos de máscaras de proteção

q) Preciso aprender mais para escolher a máscara de proteção mais eficaz

$\begin{array}{lll}0 & 1 & 2\end{array}$

3

$4 \quad 5$

6

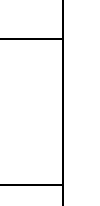




\begin{tabular}{|llllllll|}
\hline $\begin{array}{l}\text { r) Gosto do cheiro das } \\
\text { tintas/velaturas }\end{array}$ & 0 & 1 & 2 & 3 & 4 & 5 & 6 \\
\hline $\begin{array}{l}\text { s) Gosto do cheiro do } \\
\text { tapa poros }\end{array}$ & 0 & 1 & 2 & 3 & 4 & 5 & 6 \\
\hline $\begin{array}{l}\text { t) Gosto do cheiro dos } \\
\text { vernizes }\end{array}$ & 0 & 1 & 2 & 3 & 4 & 5 & 6 \\
\hline
\end{tabular}

\begin{tabular}{|c|c|c|c|c|c|c|c|}
\hline $\begin{array}{l}6 \text { - Concorda com as } \\
\text { seguintes afirmações } \\
\text { relativas aos } \\
\text { equipamentos de } \\
\text { proteção individual? }\end{array}$ & $\begin{array}{c}\text { Não } \\
\text { aplicável }\end{array}$ & $\begin{array}{c}\text { Sem } \\
\text { Opinião }\end{array}$ & $\begin{array}{c}\text { Discordo } \\
\text { Totalmente }\end{array}$ & Discordo & $\begin{array}{c}\text { Nem } \\
\text { Concordo, } \\
\text { Nem } \\
\text { Discordo }\end{array}$ & Concordo & $\begin{array}{l}\text { Concordo } \\
\text { Totalmente }\end{array}$ \\
\hline
\end{tabular}

a) Deram-me luvas de proteção para a manipulação de

$\begin{array}{lll}0 & 1 & 2\end{array}$

34

5

6

tintas/velaturas, vernizes

e tapa poros

b) Uso as luvas para a manipulação de

tintas/velaturas, vernizes

$0 \quad 1$

2

3

4

5

6

e tapa poros

c) O contato das

tintas/velaturas, vernizes

e tapa poros com a pele é

$0 \quad 1$

2

3

4

5

6

perigoso

d) Penso que as luvas que me deram são as mais adequadas

\begin{tabular}{|c|c|c|c|c|c|c|c|}
\hline $\begin{array}{l}\text { e) Sei utilizar as luvas } \\
\text { corretamente }\end{array}$ & 0 & 1 & 2 & 3 & 4 & 5 & 6 \\
\hline $\begin{array}{l}\text { f) Quando as luvas estão } \\
\text { danificadas substituo-as } \\
\text { imediatamente }\end{array}$ & 0 & 1 & 2 & 3 & 4 & 5 & 6 \\
\hline $\begin{array}{l}\text { g) Quando preciso tenho } \\
\text { sempre disponível luvas } \\
\text { de substituição }\end{array}$ & 0 & 1 & 2 & 3 & 4 & 5 & 6 \\
\hline h) Uso sempre as luvas & 0 & 1 & 2 & 3 & 4 & 5 & 6 \\
\hline
\end{tabular}




\begin{tabular}{|c|c|c|c|c|c|c|c|}
\hline $\begin{array}{l}7 \text { - Concorda com as } \\
\text { seguintes afirmações } \\
\text { relativas aos } \\
\text { equipamentos de } \\
\text { proteção individual? }\end{array}$ & $\begin{array}{c}\text { Não } \\
\text { aplicável }\end{array}$ & $\begin{array}{l}\text { Sem } \\
\text { Opinião }\end{array}$ & $\begin{array}{l}\text { Discordo } \\
\text { Totalmente }\end{array}$ & Discordo & $\begin{array}{c}\text { Nem } \\
\text { Concordo, } \\
\text { Nem } \\
\text { Discordo }\end{array}$ & Concordo & $\begin{array}{l}\text { Concordo } \\
\text { Totalmente }\end{array}$ \\
\hline $\begin{array}{l}\text { a) Deram-me fato de } \\
\text { proteção para a } \\
\text { manipulação de } \\
\text { tintas/velaturas, vernizes } \\
\text { e tapa poros }\end{array}$ & 0 & 1 & 2 & 3 & 4 & 5 & 6 \\
\hline $\begin{array}{l}\text { b) Penso que o fato que } \\
\text { me deram para a } \\
\text { manipulação de } \\
\text { tintas/velaturas, vernizes } \\
\text { e tapa poros é o mais } \\
\text { adequado }\end{array}$ & 0 & 1 & 2 & 3 & 4 & 5 & 6 \\
\hline $\begin{array}{l}\text { c) O fato tem o tamanho } \\
\text { adequado }\end{array}$ & 0 & 1 & 2 & 3 & 4 & 5 & 6 \\
\hline $\begin{array}{l}\text { d) Sei utilizar o fato } \\
\text { corretamente }\end{array}$ & 0 & 1 & 2 & 3 & 4 & 5 & 6 \\
\hline $\begin{array}{l}\text { e) Quando o fato está } \\
\text { estragado substituo-o } \\
\text { imediatamente }\end{array}$ & 0 & 1 & 2 & 3 & 4 & 5 & 6 \\
\hline $\begin{array}{l}\text { f) Quando preciso tenho } \\
\text { sempre disponível um } \\
\text { fato de substituição }\end{array}$ & 0 & 1 & 2 & 3 & 4 & 5 & 6 \\
\hline $\begin{array}{l}\text { g) No Verão não uso fato } \\
\text { de proteção }\end{array}$ & 0 & 1 & 2 & 3 & 4 & 5 & 6 \\
\hline
\end{tabular}

\begin{tabular}{|c|c|c|c|c|c|c|c|}
\hline $\begin{array}{l}8 \text { - Concorda com as } \\
\text { seguintes afirmações } \\
\text { relativas aos } \\
\text { equipamentos de } \\
\text { proteção individual? }\end{array}$ & $\begin{array}{c}\text { Não } \\
\text { aplicável }\end{array}$ & $\begin{array}{l}\text { Sem } \\
\text { Opinião }\end{array}$ & $\begin{array}{l}\text { Discordo } \\
\text { Totalmente }\end{array}$ & Discordo & $\begin{array}{c}\text { Nem } \\
\text { Concordo, } \\
\text { Nem } \\
\text { Discordo }\end{array}$ & Concordo & $\begin{array}{l}\text { Concordo } \\
\text { Totalmente }\end{array}$ \\
\hline $\begin{array}{l}\text { a) Deram-me botas para } \\
\text { a manipulação de } \\
\text { tintas/velaturas, vernizes } \\
\text { e tapa poros }\end{array}$ & 0 & 1 & 2 & 3 & 4 & 5 & 6 \\
\hline $\begin{array}{l}\text { b) Penso que as botas } \\
\text { que me deram para a } \\
\text { manipulação de } \\
\text { tintas/velaturas, vernizes } \\
\text { e tapa poros são as mais } \\
\text { adequadas }\end{array}$ & 0 & 1 & 2 & 3 & 4 & 5 & 6 \\
\hline $\begin{array}{l}\text { c) As botas têm o } \\
\text { tamanho adequado }\end{array}$ & 0 & 1 & 2 & 3 & 4 & 5 & 6 \\
\hline
\end{tabular}




\begin{tabular}{|c|c|c|c|c|c|c|c|}
\hline $\begin{array}{l}\text { d) Quando as botas estão } \\
\text { estragadas substituo-as } \\
\text { imediatamente }\end{array}$ & 0 & 1 & 2 & 3 & 4 & 5 & 6 \\
\hline $\begin{array}{l}\text { e) Quando preciso tenho } \\
\text { sempre disponível umas } \\
\text { botas de substituição }\end{array}$ & 0 & 1 & 2 & 3 & 4 & 5 & 6 \\
\hline f) Uso sempre botas & 0 & 1 & 2 & 3 & 4 & 5 & 6 \\
\hline
\end{tabular}

\begin{tabular}{|c|c|c|c|c|c|c|c|}
\hline $\begin{array}{l}9 \text { - Concorda com as } \\
\text { seguintes afirmações } \\
\text { relativas aos } \\
\text { equipamentos de } \\
\text { proteção coletiva? }\end{array}$ & $\begin{array}{c}\text { Não } \\
\text { aplicável }\end{array}$ & $\begin{array}{c}\text { Sem } \\
\text { Opinião }\end{array}$ & $\begin{array}{l}\text { Discordo } \\
\text { Totalmente }\end{array}$ & Discordo & $\begin{array}{c}\text { Nem } \\
\text { Concordo, } \\
\text { Nem } \\
\text { Discordo }\end{array}$ & Concordo & $\begin{array}{l}\text { Concordo } \\
\text { Totalmente }\end{array}$ \\
\hline $\begin{array}{l}\text { a) Não é necessário o } \\
\text { funcionamento das } \\
\text { cabines desde que utilize } \\
\text { a máscara de proteção } \\
\text { respiratória para gases }\end{array}$ & 0 & 1 & 2 & 3 & 4 & 5 & 6 \\
\hline $\begin{array}{l}\text { b) Ligo sempre as } \\
\text { cabines quando aplico as } \\
\text { tintas/velaturas, vernizes } \\
\text { e tapa poros }\end{array}$ & 0 & 1 & 2 & 3 & 4 & 5 & 6 \\
\hline $\begin{array}{l}\text { c) Não é necessário o } \\
\text { funcionamento dos } \\
\text { equipamentos de } \\
\text { extração desde que utilize } \\
\text { a máscara de proteção } \\
\text { respiratória para gases }\end{array}$ & 0 & 1 & 2 & 3 & 4 & 5 & 6 \\
\hline $\begin{array}{l}\text { d) No inverno às vezes } \\
\text { não ligo as cabines }\end{array}$ & 0 & 1 & 2 & 3 & 4 & 5 & 6 \\
\hline $\begin{array}{l}\text { e) Quando está frio não } \\
\text { ligo os equipamentos de } \\
\text { extração }\end{array}$ & 0 & 1 & 2 & 3 & 4 & 5 & 6 \\
\hline f) Uso sempre botas & 0 & 1 & 2 & 3 & 4 & 5 & 6 \\
\hline
\end{tabular}




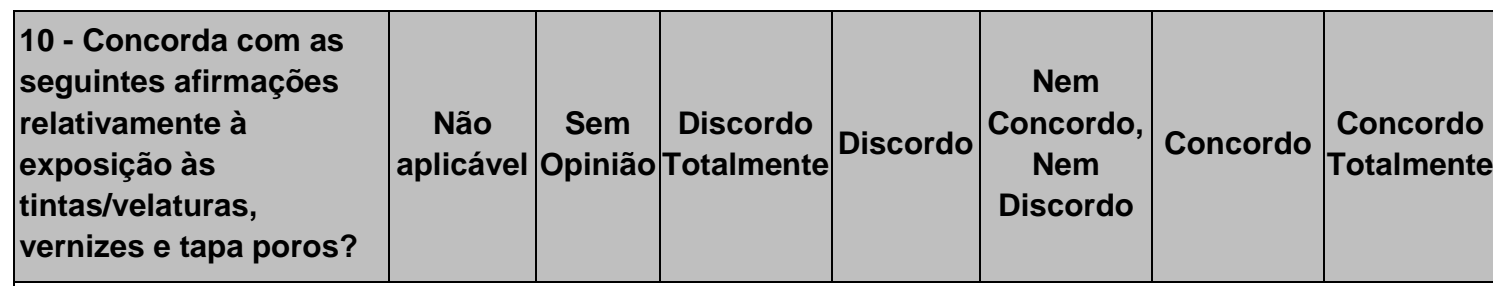

a) $A$ exposição às

tintas/velaturas, vernizes

e tapa poros provoca-me

irritação no nariz e

$\begin{array}{ll}0 & 1\end{array}$

23

4

5

6

garganta

b) A exposição às

tintas/velaturas, vernizes

e tapa poros provoca-me

$0 \quad 1$

2

3

4

5

6

irritação dos olhos

c) Durante o trabalho com

as tintas/velaturas,

vernizes e tapa poros já

0

2

3

4

5

6

tive irritação dos olhos

d) Durante o trabalho com

as tintas/velaturas,

tive irritação no nariz e

0

1

2

3

4

5

6

garganta

e) A exposição às

tintas/velaturas, vernizes

e tapa poros provoca-me

0

1

2

3

4

5

6

dores de cabeça

f) Tenho frequentemente dores de cabeça

0

1

2

3

4

5

6

g) Antes de trabalhar na empresa de mobiliário não tinha dores de

$0 \quad 1$

2

3

4

5

6

cabeça

h) Antes de trabalhar na empresa de mobiliário tinha menos dores de

$0 \quad 1$

2

3

4

5

6 cabeça

i) $A$ exposição às tintas/velaturas, vernizes e tapa poros causa-me 0

2

3

4

5

6

sonolência

j) Quando estou exposto

às tintas/velaturas,

vernizes e tapa poros

0

1

2

3

4

5

6

perco o apetite 
k) Desde que trabalho com as tintas/velaturas, vernizes e tapa poros tenho maior dificuldade $0 \quad 1$

3

4

5

6 em ouvir

I) Há muito ruído no meu posto de trabalho

0

$2 \quad 3$

$4 \quad 5$

$5 \quad 6$

m) Por vezes tenho vómitos no trabalho

$0 \quad 1$

2

3

4

5

6

n) $A$ exposição às tintas/velaturas, vernizes

e tapa poros causa-me

0

23

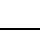

vómitos

o) Já tive vertigens/tonturas no meu posto de trabalho

p) A exposição às tintas/velaturas, vernizes e tapa poros causa-me

$0 \quad 1$

2

3

4

5

6

vertigens/tonturas

q) Quando não utilizo luvas e estou a utilizar as tintas/velaturas, vernizes 0

01

2

3

4

5

6

e tapa poros fico com a

pele seca e irritada

r) A minha

percepção/sensibilidade

aos cheiros diminuiu desde que fiquei exposto

0

1

2

3

4

5

6

às tintas/velaturas,

vernizes e tapa poros

\begin{tabular}{|c|c|c|c|c|c|c|c|}
\hline $\begin{array}{l}11 \text { - Concorda com as } \\
\text { afirmações seguintes, } \\
\text { relativamente ao meu } \\
\text { posto de trabalho? }\end{array}$ & $\begin{array}{c}\text { Não } \\
\text { aplicável }\end{array}$ & $\begin{array}{c}\text { Sem } \\
\text { Opinião }\end{array}$ & Nunca & Raramente & $\begin{array}{l}\text { Algumas } \\
\text { vezes }\end{array}$ & $\begin{array}{c}\text { Maioria } \\
\text { das Vezes }\end{array}$ & Sempre \\
\hline $\begin{array}{l}\text { a) Ritmo de trabalho } \\
\text { muito intenso }\end{array}$ & 0 & 1 & 2 & 3 & 4 & 5 & 6 \\
\hline $\begin{array}{l}\text { b) Por vezes noto muito } \\
\text { cheiro aos produtos } \\
\text { químicos }\end{array}$ & 0 & 1 & 2 & 3 & 4 & 5 & 6 \\
\hline
\end{tabular}


c) Às vezes os recipientes vazios das

tintas/velaturas, vernizes

e tapa poros não são

0

12

3

4

5

6

retirados imediatamente

dos postos de trabalho

d) Estou satisfeito com o

funcionamento das

$\begin{array}{lll}0 & 1 & 2\end{array}$

3

4

5

6

cabines de aspiração

e) Acho que as cabines

de aspiração têm a

$\begin{array}{lll}0 & 1 & 2\end{array}$

23

34

45

$5 \quad 6$

manutenção adequada

f) É possível diminuir a exposição às

tintas/velaturas, vernizes

$\begin{array}{lll}0 & 1 & 2\end{array}$

23

4

5

6

e tapa poros

g) É possível diminuir a exposição aos cheiros das tintas/velaturas,

$\begin{array}{lll}0 & 1 & 2\end{array}$

23

4

5

6

vernizes e tapa poros

h) Existe preocupação da empresa em diminuir a exposição às

$0 \quad 1$

2

3

4

5

6

tintas/velaturas, vernizes

e tapa poros

\begin{tabular}{|c|c|c|c|c|c|c|c|}
\hline $\begin{array}{l}12 \text { - Qual a frequência } \\
\text { das seguintes atitudes? }\end{array}$ & $\begin{array}{c}\text { Não } \\
\text { aplicável }\end{array}$ & $\begin{array}{c}\text { Sem } \\
\text { Opinião }\end{array}$ & Nunca & Raramente & $\begin{array}{c}\text { Algumas } \\
\text { vezes }\end{array}$ & $\begin{array}{c}\text { Maioria } \\
\text { das Vezes }\end{array}$ & Sempre \\
\hline $\begin{array}{l}\text { a) Não cumprir as regras } \\
\text { de segurança }\end{array}$ & 0 & 1 & 2 & 3 & 4 & 5 & 6 \\
\hline $\begin{array}{l}\text { b) Executar as atividades } \\
\text { de acordo com as } \\
\text { instruções de trabalho }\end{array}$ & 0 & 1 & 2 & 3 & 4 & 5 & 6 \\
\hline $\begin{array}{l}\text { c) Executar as atividades } \\
\text { de acordo com o que a } \\
\text { empresa me ensinou }\end{array}$ & 0 & 1 & 2 & 3 & 4 & 5 & 6 \\
\hline $\begin{array}{l}\text { d) Usar sempre luvas na } \\
\text { manipulação das } \\
\text { tintas/velaturas, vernizes } \\
\text { e tapa poros }\end{array}$ & 0 & 1 & 2 & 3 & 4 & 5 & 6 \\
\hline $\begin{array}{l}\text { e) Usar sempre avental } \\
\text { na manipulação das } \\
\text { tintas/velaturas, vernizes } \\
\text { e tapa poros }\end{array}$ & 0 & 1 & 2 & 3 & 4 & 5 & 6 \\
\hline
\end{tabular}


f) Usar sempre fato de proteção na manipulação das tintas/velaturas,

0

$\begin{array}{lll}0 & 1 & 2\end{array}$

23

4

5

6

vernizes e tapa poros

g) Utilizar sempre a

máscara de proteção na

manipulação das

0

12

3

4

5

6

tintas/velaturas, vernizes

e tapa poros

\begin{tabular}{|l|l|l|}
\cline { 2 - 3 } \multicolumn{1}{l|}{} & SIM & NÃO \\
\hline 14 - Já tive formação dive formação sobre os riscos dos produtos químicos & & \\
\hline 15 - Já tive formação acerca do manuseamento correto dos produtos químicos & & \\
\hline 16 - Já tive formação de como proceder no caso de derrame dos produtos químicos & & \\
\hline 17 - Já tive formação sobre saúde e segurança na aplicação dos produtos químicos & & \\
\hline
\end{tabular}

\begin{tabular}{|l|l|l|l|l|l|}
\hline & $\begin{array}{c}\text { Antes de } \\
2011\end{array}$ & 2011 & 2012 & 2013 & 2014 \\
\hline $\begin{array}{l}\text { 18 - A última vez que tive formação sobre os riscos } \\
\text { laborais no meu posto de trabalho }\end{array}$ & & & & & \\
\hline
\end{tabular}

Se tem alguma opinião ou sugestão para melhorar as condições de trabalho por favor escreva em baixo.

\section{SUGESTÕES:}




\subsection{Conhecimento do Risco dos Produtos Químicos}

Tabela 11 - Respostas Sobre a Classificação do Risco associado às tintas/velaturas da madeira

\begin{tabular}{c|ccccccc}
\hline \hline & $\begin{array}{c}\text { Não } \\
\text { aplicável } \\
(\%)\end{array}$ & $\begin{array}{c}\text { Sem } \\
\text { opinião } \\
(\%)\end{array}$ & $\begin{array}{c}\text { Nenhum } \\
\text { Risco } \\
(\%)\end{array}$ & $\begin{array}{c}\text { Pouco } \\
\text { Risco } \\
(\%)\end{array}$ & $\begin{array}{c}\text { Médio } \\
\text { Risco } \\
(\%)\end{array}$ & $\begin{array}{c}\text { Muito } \\
\text { Risco } \\
(\%)\end{array}$ & $\begin{array}{c}\text { Elevadíssimo } \\
\text { Risco } \\
(\%)\end{array}$ \\
\hline $\begin{array}{c}\text { Cabine de } \\
\text { aplicação de } \\
\text { tintas, vernizes e } \\
\text { tapa poros } \\
\text { Lixagem }\end{array}$ & 0,0 & 3,6 & 0,7 & 5,7 & 12,1 & 16,4 & 0,7 \\
Apoio & 7,2 & 5,0 & 0,0 & 5,0 & 15,0 & 8,6 & 0,7 \\
Outro & 2,1 & 0,7 & 1,4 & 3,6 & 5,0 & 0,7 & 1,4 \\
Total & 0,0 & 0,0 & 0,7 & 1,4 & 0,7 & 1,4 & 0,0 \\
\hline \hline
\end{tabular}

Tabela 12 - Respostas Sobre a Classificação do Risco associado ao verniz

\begin{tabular}{c|ccccccc}
\hline \hline & $\begin{array}{c}\text { Não } \\
\text { aplicável } \\
(\%)\end{array}$ & $\begin{array}{c}\text { Sem } \\
\text { opinião } \\
(\%)\end{array}$ & $\begin{array}{c}\text { Nenhum } \\
\text { Risco } \\
(\%)\end{array}$ & $\begin{array}{c}\text { Pouco } \\
\text { Risco } \\
(\%)\end{array}$ & $\begin{array}{c}\text { Médio } \\
\text { Risco } \\
(\%)\end{array}$ & $\begin{array}{c}\text { Muito } \\
\text { Risco } \\
(\%)\end{array}$ & $\begin{array}{c}\text { Elevadíssimo } \\
\text { Risco } \\
(\%)\end{array}$ \\
\hline $\begin{array}{c}\text { Cabine de } \\
\text { aplicação de } \\
\text { tintas, vernizes e } \\
\text { tapa poros } \\
\text { Lixagem }\end{array}$ & 0,0 & 0,7 & 0,7 & 3,6 & 20,0 & 13,6 & 1,4 \\
Apoio & 7,9 & 3,6 & 0,7 & 4,3 & 7,9 & 15,0 & 1,4 \\
Outro & 0,7 & 0,7 & 0,0 & 2,9 & 7,9 & 1,4 & 1,4 \\
Total & 0,7 & 0,0 & 0,7 & 1,4 & 0,7 & 0,7 & 0,0 \\
\hline \hline
\end{tabular}


Tabela 13 - Respostas Sobre a Classificação do Risco associado ao tapa poros

\begin{tabular}{c|ccccccc}
\hline \hline & $\begin{array}{c}\text { Não } \\
\text { aplicável } \\
(\%)\end{array}$ & $\begin{array}{c}\text { Sem } \\
\text { opinião } \\
(\%)\end{array}$ & $\begin{array}{c}\text { Nenhum } \\
\text { Risco } \\
(\%)\end{array}$ & $\begin{array}{c}\text { Pouco } \\
\text { Risco } \\
(\%)\end{array}$ & $\begin{array}{c}\text { Médio } \\
\text { Risco } \\
(\%)\end{array}$ & $\begin{array}{c}\text { Muito } \\
\text { Risco } \\
(\%)\end{array}$ & $\begin{array}{c}\text { Elevadíssimo } \\
\text { Risco } \\
(\%)\end{array}$ \\
\hline $\begin{array}{c}\text { Cabine de } \\
\text { aplicação de } \\
\text { tintas, vernizes e } \\
\text { tapa poros } \\
\text { Lixagem }\end{array}$ & 0,0 & 2,8 & 0,7 & 4,2 & 18,3 & 11,3 & 2,1 \\
Apoio & 6,3 & 4,2 & 0,7 & 6,3 & 11,3 & 10,6 & 2,1 \\
Outro & 2,1 & 0,7 & 1,4 & 2,1 & 4,9 & 2,1 & 1,4 \\
Total & 0,7 & 0,0 & 0,7 & 1,4 & 0,7 & 0,7 & 0,0 \\
\hline \hline
\end{tabular}

Tabela 14 - Respostas Sobre a Classificação do Risco associado ao xileno

\begin{tabular}{c|ccccccc}
\hline \hline & $\begin{array}{c}\text { Não } \\
\text { aplicável } \\
(\%)\end{array}$ & $\begin{array}{c}\text { Sem } \\
\text { opinião } \\
(\%)\end{array}$ & $\begin{array}{c}\text { Nenhum } \\
\text { Risco } \\
(\%)\end{array}$ & $\begin{array}{c}\text { Pouco } \\
\text { Risco } \\
(\%)\end{array}$ & $\begin{array}{c}\text { Médio } \\
\text { Risco } \\
(\%)\end{array}$ & $\begin{array}{c}\text { Muito } \\
\text { Risco } \\
(\%)\end{array}$ & $\begin{array}{c}\text { Elevadíssimo } \\
\text { Risco } \\
(\%)\end{array}$ \\
\hline $\begin{array}{c}\text { Cabine de } \\
\text { aplicação de } \\
\text { tintas, vernizes e } \\
\text { tapa poros } \\
\text { Lixagem }\end{array}$ & 8,0 & 15,2 & 0,0 & 0,7 & 3,6 & 8,7 & 2,9 \\
Apoio & 10,1 & 23,2 & 0,0 & 3,6 & 1,4 & 2,9 & 1,4 \\
Outro & 2,9 & 4,3 & 0,0 & 1,4 & 2,9 & 0,7 & 1,4 \\
Total & 0,7 & 1,4 & 0,0 & 1,4 & 0,0 & 0,0 & 0,7 \\
\hline \hline
\end{tabular}


Tabela 15 - Respostas Sobre a Classificação do Risco associado ao tolueno

\begin{tabular}{c|ccccccc}
\hline \hline & $\begin{array}{c}\text { Não } \\
\text { aplicável } \\
(\%)\end{array}$ & $\begin{array}{c}\text { Sem } \\
\text { opinião } \\
(\%)\end{array}$ & $\begin{array}{c}\text { Nenhum } \\
\text { Risco } \\
(\%)\end{array}$ & $\begin{array}{c}\text { Pouco } \\
\text { Risco } \\
(\%)\end{array}$ & $\begin{array}{c}\text { Médio } \\
\text { Risco } \\
(\%)\end{array}$ & $\begin{array}{c}\text { Muito } \\
\text { Risco } \\
(\%)\end{array}$ & $\begin{array}{c}\text { Elevadíssimo } \\
\text { Risco } \\
(\%)\end{array}$ \\
\hline $\begin{array}{c}\text { Cabine de } \\
\text { aplicação de } \\
\text { tintas, vernizes e } \\
\text { tapa poros } \\
\text { Lixagem }\end{array}$ & 6,5 & 17,3 & 0,0 & 1,4 & 2,9 & 5,0 & 5,0 \\
Apoio & 10,1 & 23,0 & 0,0 & 3,6 & 1,4 & 2,9 & 1,4 \\
Outro & 2,9 & 6,5 & 0,0 & 0,7 & 2,2 & 1,4 & 1,4 \\
Total & 1,4 & 1,4 & 0,0 & 0,7 & 0,0 & 0,0 & 0,7 \\
\hline \hline
\end{tabular}

Tabela 16 - Respostas Sobre a Classificação do Risco associado ao diluente

\begin{tabular}{c|ccccccc}
\hline \hline & $\begin{array}{c}\text { Não } \\
\text { aplicável } \\
(\%)\end{array}$ & $\begin{array}{c}\text { Sem } \\
\text { opinião } \\
(\%)\end{array}$ & $\begin{array}{c}\text { Nenhum } \\
\text { Risco } \\
(\%)\end{array}$ & $\begin{array}{c}\text { Pouco } \\
\text { Risco } \\
(\%)\end{array}$ & $\begin{array}{c}\text { Médio } \\
\text { Risco } \\
(\%)\end{array}$ & $\begin{array}{c}\text { Muito } \\
\text { Risco } \\
(\%)\end{array}$ & $\begin{array}{c}\text { Elevadíssimo } \\
\text { Risco } \\
(\%)\end{array}$ \\
\hline $\begin{array}{c}\text { Cabine de } \\
\text { aplicação de } \\
\text { tintas, vernizes e } \\
\text { tapa poros } \\
\text { Lixagem }\end{array}$ & 0,7 & 0,7 & 0,7 & 2,1 & 13,6 & 13,6 & 7,1 \\
Apoio & 7,1 & 4,3 & 0,0 & 4,3 & 8,6 & 11,4 & 6,4 \\
Outro & 0,0 & 0,7 & 0,0 & 2,1 & 4,3 & 3,6 & 4,3 \\
Total & 0,0 & 7,7 & 0,0 & 2,1 & 0,7 & 1,4 & 0,0 \\
\hline \hline
\end{tabular}




\subsection{Conhecimento dos Produtos Químicos Utilizados}

Tabela 17 - Respostas Sobre a Afirmação: "Sei distinguir as tintas/velaturas, vernizes e tapa poros"

\begin{tabular}{c|ccccccc}
\hline \hline & $\begin{array}{c}\text { Não } \\
\text { aplicável } \\
(\%)\end{array}$ & $\begin{array}{c}\text { Sem } \\
\text { opinião } \\
(\%)\end{array}$ & $\begin{array}{c}\text { Discordo } \\
\text { Totalmente } \\
(\%)\end{array}$ & $\begin{array}{c}\text { Discordo } \\
(\%)\end{array}$ & $\begin{array}{c}\text { Nem } \\
\text { concordo, } \\
\text { nem } \\
\text { Discordo } \\
(\%)\end{array}$ & $\begin{array}{c}\text { Concordo } \\
(\%)\end{array}$ & $\begin{array}{c}\text { Concordo } \\
\text { Totalmente } \\
(\%)\end{array}$ \\
\hline $\begin{array}{c}\text { Cabine de } \\
\text { aplicação de } \\
\text { tintas, vernizes } \\
\text { e tapa poros } \\
\text { Lixagem }\end{array}$ & 0,0 & 0,7 & 0,7 & 0,7 & 1,4 & 16,2 & 19,7 \\
Apoio & 6,3 & 6,3 & 0,7 & 0,7 & 2,8 & 16,9 & 7,7 \\
Outro & 0,7 & 1,4 & 0,7 & 0,0 & 1,4 & 9,2 & 1,4 \\
Total & 0,0 & 0,0 & 0,0 & 0,0 & 0,0 & 2,8 & 1,4 \\
\hline \hline
\end{tabular}

Tabela 18 - Respostas Sobre a Afirmação: "Já li as fichas de dados de segurança dos produtos químicos que utilizo"

\begin{tabular}{c|ccccccc}
\hline & $\begin{array}{c}\text { Não } \\
\text { aplicável } \\
(\%)\end{array}$ & $\begin{array}{c}\text { Sem } \\
\text { opinião } \\
(\%)\end{array}$ & $\begin{array}{c}\text { Discordo } \\
\text { Totalmente } \\
(\%)\end{array}$ & $\begin{array}{c}\text { Niscordo } \\
(\%)\end{array}$ & $\begin{array}{c}\text { Nem } \\
\text { concordo, } \\
\text { nem } \\
\text { Discordo } \\
(\%)\end{array}$ & $\begin{array}{c}\text { Concordo } \\
(\%)\end{array}$ & $\begin{array}{c}\text { Concordo } \\
\text { Totalmente } \\
(\%)\end{array}$ \\
\hline $\begin{array}{c}\text { Cabine de } \\
\text { aplicação de } \\
\text { tintas, vernizes } \\
\text { e tapa poros } \\
\text { Lixagem }\end{array}$ & 0,7 & 2,8 & 0,7 & 0,0 & 4,3 & 21,3 & 9,9 \\
Apoio & 12,1 & 4,3 & 2,8 & 3,5 & 2,8 & 13,5 & 2,1 \\
Outro & 1,4 & 2,1 & 0,7 & 1,4 & 1,4 & 6,4 & 1,4 \\
Total & 0,7 & 0,0 & 0,0 & 0,0 & 0,0 & 2,1 & 1,4 \\
\hline \hline
\end{tabular}


Tabela 19 - Respostas Sobre a Afirmação: "O xileno e o tolueno são substâncias químicas que compõem as tintas/velaturas, vernizes e tapa poros"

\begin{tabular}{c|ccccccc}
\hline & $\begin{array}{c}\text { Não } \\
\text { aplicável } \\
(\%)\end{array}$ & $\begin{array}{c}\text { Sem } \\
\text { opinião } \\
(\%)\end{array}$ & $\begin{array}{c}\text { Discordo } \\
\text { Totalmente } \\
(\%)\end{array}$ & $\begin{array}{c}\text { Discordo } \\
(\%)\end{array}$ & $\begin{array}{c}\text { Nem } \\
\text { concordo, } \\
\text { nem } \\
\text { Discordo } \\
(\%)\end{array}$ & $\begin{array}{c}\text { Concordo } \\
(\%)\end{array}$ & $\begin{array}{c}\text { Concordo } \\
\text { Totalmente } \\
(\%)\end{array}$ \\
\hline $\begin{array}{c}\text { Cabine de } \\
\text { aplicação de } \\
\text { tintas, vernizes } \\
\text { e tapa poros } \\
\text { Lixagem }\end{array}$ & 2,9 & 17,9 & 0,7 & 0,0 & 4,3 & 7,9 & 6,4 \\
$\begin{array}{c}\text { Apoio } \\
\text { Outro }\end{array}$ & 11,4 & 19,3 & 1,4 & 0,7 & 3,6 & 2,9 & 1,4 \\
Total & 2,1 & 7,9 & 0,0 & 0,0 & 2,1 & 2,9 & 0,0 \\
\hline \hline
\end{tabular}

Tabela 20 - Respostas Sobre a Afirmação: "As tintas/velaturas, vernizes e tapa poros que utilizo são de base solvente"

\begin{tabular}{c|ccccccc}
\hline \hline & $\begin{array}{c}\text { Não } \\
\text { aplicável } \\
(\%)\end{array}$ & $\begin{array}{c}\text { Sem } \\
\text { opinião } \\
(\%)\end{array}$ & $\begin{array}{c}\text { Discordo } \\
\text { Totalmente } \\
(\%)\end{array}$ & $\begin{array}{c}\text { Discordo } \\
(\%)\end{array}$ & $\begin{array}{c}\text { Nem } \\
\text { concordo, } \\
\text { nem } \\
\text { Discordo } \\
(\%)\end{array}$ & $\begin{array}{c}\text { Concordo } \\
(\%)\end{array}$ & $\begin{array}{c}\text { Concordo } \\
\text { Totalmente } \\
(\%)\end{array}$ \\
\hline $\begin{array}{c}\text { Cabine de } \\
\text { aplicação de } \\
\text { tintas, vernizes } \\
\text { e tapa poros } \\
\text { Lixagem }\end{array}$ & 0,7 & 4,3 & 1,4 & 2,1 & 2,1 & 22,0 & 7,1 \\
Apoio & 9,2 & 14,9 & 0,0 & 1,4 & 2,8 & 11,3 & 1,4 \\
Outro & 2,8 & 2,8 & 0,0 & 1,4 & 0,7 & 7,1 & 0,0 \\
Total & 0,0 & 1,4 & 0,0 & 0,0 & 0,0 & 1,4 & 1,4 \\
\hline \hline
\end{tabular}


Tabela 21 - Respostas Sobre a Afirmação: "As tintas/velaturas, vernizes e tapa poros que utilizo de base solvente têm os mesmos riscos se forem de base aquosa"

\begin{tabular}{c|ccccccc}
\hline \hline & $\begin{array}{c}\text { Não } \\
\text { aplicável } \\
(\%)\end{array}$ & $\begin{array}{c}\text { Sem } \\
\text { opinião } \\
(\%)\end{array}$ & $\begin{array}{c}\text { Discordo } \\
\text { Totalmente } \\
(\%)\end{array}$ & $\begin{array}{c}\text { Discordo } \\
(\%)\end{array}$ & $\begin{array}{c}\text { Nem } \\
\text { concordo, } \\
\text { nem } \\
\text { Discordo } \\
(\%)\end{array}$ & $\begin{array}{c}\text { Concordo } \\
(\%)\end{array}$ & $\begin{array}{c}\text { Concordo } \\
\text { Totalmente } \\
(\%)\end{array}$ \\
\hline $\begin{array}{c}\text { Cabine de } \\
\text { aplicação de } \\
\text { tintas, vernizes } \\
\text { e tapa poros } \\
\text { Lixagem }\end{array}$ & 1,4 & 4,3 & 10,6 & 15,6 & 5,7 & 2,1 & 0,0 \\
$\quad \begin{array}{c}\text { Apoio } \\
\text { Outro }\end{array}$ & 9,2 & 14,2 & 2,8 & 9,2 & 1,4 & 3,5 & 0,7 \\
Total & 2,1 & 3,5 & 2,8 & 2,8 & 2,1 & 1,4 & 0,0 \\
\hline \hline
\end{tabular}




\subsection{Comportamentos na Manipulação de Produtos Químicos}

Tabela 22 - Respostas Sobre a Classificação do Risco associado à exposição às tintas/velaturas

\begin{tabular}{c|ccccccc}
\hline \hline & $\begin{array}{c}\text { Não } \\
\text { aplicável } \\
(\%)\end{array}$ & $\begin{array}{c}\text { Sem } \\
\text { opinião } \\
(\%)\end{array}$ & $\begin{array}{c}\text { Nenhum } \\
\text { Risco } \\
(\%)\end{array}$ & $\begin{array}{c}\text { Pouco } \\
\text { Risco } \\
(\%)\end{array}$ & $\begin{array}{c}\text { Médio } \\
\text { Risco } \\
(\%)\end{array}$ & $\begin{array}{c}\text { Muito } \\
\text { Risco } \\
(\%)\end{array}$ & $\begin{array}{c}\text { Elevadíssimo } \\
\text { Risco } \\
(\%)\end{array}$ \\
\hline $\begin{array}{c}\text { Cabine de } \\
\text { aplicação de } \\
\text { tintas, vernizes e } \\
\text { tapa poros } \\
\text { Lixagem }\end{array}$ & 0,7 & 1,4 & 0,7 & 4,9 & 13,6 & 13,4 & 2,8 \\
Apoio & 12,7 & 2,1 & 0,7 & 2,8 & 8,6 & 10,6 & 2,8 \\
Outro & 2,1 & 2,1 & 1,4 & 2,1 & 4,3 & 4,9 & 0,7 \\
Total & 0,0 & 0,0 & 0,0 & 2,1 & 0,7 & 0,0 & 0,0 \\
\hline \hline
\end{tabular}

Tabela 23 - Respostas Sobre a Classificação do Risco associado à exposição ao tapa poros

\begin{tabular}{c|ccccccc}
\hline \hline & $\begin{array}{c}\text { Não } \\
\text { aplicável } \\
(\%)\end{array}$ & $\begin{array}{c}\text { Sem } \\
\text { opinião } \\
(\%)\end{array}$ & $\begin{array}{c}\text { Nenhum } \\
\text { Risco } \\
(\%)\end{array}$ & $\begin{array}{c}\text { Pouco } \\
\text { Risco } \\
(\%)\end{array}$ & $\begin{array}{c}\text { Médio } \\
\text { Risco } \\
(\%)\end{array}$ & $\begin{array}{c}\text { Muito } \\
\text { Risco } \\
(\%)\end{array}$ & $\begin{array}{c}\text { Elevadíssimo } \\
\text { Risco } \\
(\%)\end{array}$ \\
\hline $\begin{array}{c}\text { Cabine de } \\
\text { aplicação de } \\
\text { tintas, vernizes e } \\
\text { tapa poros } \\
\text { Lixagem }\end{array}$ & 0,7 & 0,7 & 0,7 & 4,2 & 16,2 & 13,4 & 3,5 \\
Apoio & 12,7 & 2,8 & 0,0 & 4,2 & 9,9 & 8,5 & 3,5 \\
Outro & 1,4 & 1,4 & 1,4 & 2,8 & 4,2 & 2,8 & 0,7 \\
Total & 0,7 & 0,0 & 0,0 & 2,1 & 0,0 & 1,4 & 0,0 \\
\hline \hline
\end{tabular}


Tabela 24 - Respostas Sobre a Classificação do Risco associado à exposição aos vernizes

\begin{tabular}{c|ccccccc}
\hline \hline & $\begin{array}{c}\text { Não } \\
\text { aplicável } \\
(\%)\end{array}$ & $\begin{array}{c}\text { Sem } \\
\text { opinião } \\
(\%)\end{array}$ & $\begin{array}{c}\text { Nenhum } \\
\text { Risco } \\
(\%)\end{array}$ & $\begin{array}{c}\text { Pouco } \\
\text { Risco } \\
(\%)\end{array}$ & $\begin{array}{c}\text { Médio } \\
\text { Risco } \\
(\%)\end{array}$ & $\begin{array}{c}\text { Muito } \\
\text { Risco } \\
(\%)\end{array}$ & $\begin{array}{c}\text { Elevadíssimo } \\
\text { Risco } \\
(\%)\end{array}$ \\
\hline $\begin{array}{c}\text { Cabine de } \\
\text { aplicação de } \\
\text { tintas, vernizes e } \\
\text { tapa poros } \\
\text { Lixagem }\end{array}$ & 0,7 & 0,7 & 0,7 & 4,3 & 14,2 & 15,6 & 2,8 \\
Apoio & 13,5 & 2,1 & 0,0 & 2,1 & 10,6 & 2,3 & 2,1 \\
Outro & 0,7 & 2,1 & 0,0 & 3,5 & 5,0 & 2,8 & 0,7 \\
Total & 0,7 & 0,0 & 0,0 & 2,1 & 0,0 & 1,4 & 0,0 \\
\hline \hline
\end{tabular}

Tabela 25 - Respostas Sobre a Classificação do Risco associado à exposição aos diluentes

\begin{tabular}{c|ccccccc}
\hline \hline & $\begin{array}{c}\text { Não } \\
\text { aplicável } \\
(\%)\end{array}$ & $\begin{array}{c}\text { Sem } \\
\text { opinião } \\
(\%)\end{array}$ & $\begin{array}{c}\text { Nenhum } \\
\text { Risco } \\
(\%)\end{array}$ & $\begin{array}{c}\text { Pouco } \\
\text { Risco } \\
(\%)\end{array}$ & $\begin{array}{c}\text { Médio } \\
\text { Risco } \\
(\%)\end{array}$ & $\begin{array}{c}\text { Muito } \\
\text { Risco } \\
(\%)\end{array}$ & $\begin{array}{c}\text { Elevadíssimo } \\
\text { Risco } \\
(\%)\end{array}$ \\
\hline $\begin{array}{c}\text { Cabine de } \\
\text { aplicação de } \\
\text { tintas, vernizes e } \\
\text { tapa poros } \\
\text { Lixagem }\end{array}$ & 0,7 & 0,7 & 1,4 & 2,1 & 12,8 & 16,3 & 5,7 \\
Apoio & 13,5 & 2,8 & 0,0 & 2,1 & 5,0 & 14,2 & 3,5 \\
Outro & 0,0 & 0,7 & 0,0 & 2,1 & 3,5 & 5,7 & 2,8 \\
Total & 0,0 & 0,0 & 0,0 & 1,4 & 0,0 & 2,8 & 0,0 \\
\hline \hline
\end{tabular}


Tabela 26 - Respostas Sobre a Classificação do Risco associado à exposição a lubrificantes

\begin{tabular}{c|ccccccc}
\hline \hline & $\begin{array}{c}\text { Não } \\
\text { aplicável } \\
(\%)\end{array}$ & $\begin{array}{c}\text { Sem } \\
\text { opinião } \\
(\%)\end{array}$ & $\begin{array}{c}\text { Nenhum } \\
\text { Risco } \\
(\%)\end{array}$ & $\begin{array}{c}\text { Pouco } \\
\text { Risco } \\
(\%)\end{array}$ & $\begin{array}{c}\text { Médio } \\
\text { Risco } \\
(\%)\end{array}$ & $\begin{array}{c}\text { Muito } \\
\text { Risco } \\
(\%)\end{array}$ & $\begin{array}{c}\text { Elevadíssimo } \\
\text { Risco } \\
(\%)\end{array}$ \\
\hline $\begin{array}{c}\text { Cabine de } \\
\text { aplicação de } \\
\text { tintas, vernizes e } \\
\text { tapa poros } \\
\text { Lixagem }\end{array}$ & 12,4 & 8,0 & 0,7 & 3,6 & 9,5 & 2,9 & 0,7 \\
Apoio & 20,4 & 9,5 & 1,5 & 0,7 & 6,6 & 2,9 & 0,7 \\
Outro & 5,8 & 2,2 & 0,7 & 1,5 & 3,6 & 0,0 & 1,5 \\
Total & 2,2 & 0,0 & 0,0 & 1,5 & 0,0 & 0,7 & 0,0 \\
\hline \hline
\end{tabular}

Tabela 27 - Respostas Sobre a Classificação do Risco associado à aplicação das tintas/velaturas, tapa poros e vernizes

\begin{tabular}{c|ccccccc}
\hline \hline & $\begin{array}{c}\text { Não } \\
\text { aplicável } \\
(\%)\end{array}$ & $\begin{array}{c}\text { Sem } \\
\text { opinião } \\
(\%)\end{array}$ & $\begin{array}{c}\text { Nenhum } \\
\text { Risco } \\
(\%)\end{array}$ & $\begin{array}{c}\text { Pouco } \\
\text { Risco } \\
(\%)\end{array}$ & $\begin{array}{c}\text { Médio } \\
\text { Risco } \\
(\%)\end{array}$ & $\begin{array}{c}\text { Muito } \\
\text { Risco } \\
(\%)\end{array}$ & $\begin{array}{c}\text { Elevadíssimo } \\
\text { Risco } \\
(\%)\end{array}$ \\
\hline $\begin{array}{c}\text { Cabine de } \\
\text { aplicação de } \\
\text { tintas, vernizes e } \\
\text { tapa poros } \\
\text { Lixagem }\end{array}$ & 0,7 & 0,7 & 0,7 & 2,1 & 15,5 & 16,2 & 3,5 \\
Apoio & 19,7 & 4,9 & 2,1 & 1,4 & 3,5 & 7,0 & 2,8 \\
Outro & 1,4 & 1,4 & 0,0 & 1,4 & 5,6 & 3,5 & 1,4 \\
Total & 0,0 & 0,0 & 0,0 & 1,4 & 0,7 & 2,1 & 0,0 \\
\hline \hline
\end{tabular}


Tabela 28 - Respostas Sobre a Classificação do Risco associado à diluição das tintas/velaturas, tapa poros e vernizes

\begin{tabular}{c|ccccccc}
\hline \hline & $\begin{array}{c}\text { Não } \\
\text { aplicável } \\
(\%)\end{array}$ & $\begin{array}{c}\text { Sem } \\
\text { opinião } \\
(\%)\end{array}$ & $\begin{array}{c}\text { Nenhum } \\
\text { Risco } \\
(\%)\end{array}$ & $\begin{array}{c}\text { Pouco } \\
\text { Risco } \\
(\%)\end{array}$ & $\begin{array}{c}\text { Médio } \\
\text { Risco } \\
(\%)\end{array}$ & $\begin{array}{c}\text { Muito } \\
\text { Risco } \\
(\%)\end{array}$ & $\begin{array}{c}\text { Elevadíssimo } \\
\text { Risco } \\
(\%)\end{array}$ \\
\hline $\begin{array}{c}\text { Cabine de } \\
\text { aplicação de } \\
\text { tintas, vernizes e } \\
\text { tapa poros } \\
\text { Lixagem }\end{array}$ & 0,7 & 0,7 & 1,4 & 1,4 & 14,3 & 16,4 & 4,3 \\
Apoio & 18,6 & 6,4 & 0,0 & 2,9 & 2,9 & 7,1 & 4,3 \\
Outro & 1,4 & 2,1 & 0,0 & 1,4 & 6,4 & 1,4 & 1,4 \\
Total & 0,0 & 0,0 & 0,0 & 2,1 & 0,0 & 2,1 & 0,0 \\
\hline \hline
\end{tabular}

Tabela 29 - Respostas Sobre a Classificação do Risco associado à aplicação das tintas/velaturas, tapa poros e vernizes com as cabines desligadas

\begin{tabular}{c|ccccccc}
\hline \hline & $\begin{array}{c}\text { Não } \\
\text { aplicável } \\
(\%)\end{array}$ & $\begin{array}{c}\text { Sem } \\
\text { opinião } \\
(\%)\end{array}$ & $\begin{array}{c}\text { Nenhum } \\
\text { Risco } \\
(\%)\end{array}$ & $\begin{array}{c}\text { Pouco } \\
\text { Risco } \\
(\%)\end{array}$ & $\begin{array}{c}\text { Médio } \\
\text { Risco } \\
(\%)\end{array}$ & $\begin{array}{c}\text { Muito } \\
\text { Risco } \\
(\%)\end{array}$ & $\begin{array}{c}\text { Elevadíssimo } \\
\text { Risco } \\
(\%)\end{array}$ \\
\hline $\begin{array}{c}\text { Cabine de } \\
\text { aplicação de } \\
\text { tintas, vernizes e } \\
\text { tapa poros } \\
\text { Lixagem }\end{array}$ & 2,8 & 0,0 & 0,7 & 0,7 & 3,5 & 13,4 & 18,3 \\
Apoio & 14,1 & 4,2 & 0,0 & 0,7 & 0,7 & 7,7 & 14,1 \\
Outro & 2,1 & 0,7 & 0,0 & 0,7 & 0,0 & 6,3 & 4,9 \\
Total & 0,0 & 0,7 & 0,0 & 0,7 & 0,7 & 2,1 & 0,0 \\
\hline \hline
\end{tabular}


Tabela 30 - Respostas Sobre a Classificação do Risco associado à aplicação das tintas/velaturas, tapa poros e vernizes fora das cabines

\begin{tabular}{c|ccccccc}
\hline \hline & $\begin{array}{c}\text { Não } \\
\text { aplicável } \\
(\%)\end{array}$ & $\begin{array}{c}\text { Sem } \\
\text { opinião } \\
(\%)\end{array}$ & $\begin{array}{c}\text { Nenhum } \\
\text { Risco } \\
(\%)\end{array}$ & $\begin{array}{c}\text { Pouco } \\
\text { Risco } \\
(\%)\end{array}$ & $\begin{array}{c}\text { Médio } \\
\text { Risco } \\
(\%)\end{array}$ & $\begin{array}{c}\text { Muito } \\
\text { Risco } \\
(\%)\end{array}$ & $\begin{array}{c}\text { Elevadíssimo } \\
\text { Risco } \\
(\%)\end{array}$ \\
\hline $\begin{array}{c}\text { Cabine de } \\
\text { aplicação de } \\
\text { tintas, vernizes e } \\
\text { tapa poros } \\
\text { Lixagem }\end{array}$ & 3,6 & 0,7 & 0,0 & 0,7 & 5,0 & 13,6 & 16,4 \\
Apoio & 14,3 & 5,7 & 0,0 & 0,0 & 0,7 & 9,3 & 10,7 \\
Outro & 1,4 & 0,7 & 0,7 & 0,0 & 0,7 & 7,9 & 3,6 \\
Total & 0,0 & 0,7 & 0,7 & 0,7 & 0,0 & 0,7 & 1,4 \\
\hline \hline
\end{tabular}

Tabela 31 - Respostas Sobre a Classificação do Risco associado à proximidade da estufa de secagem

\begin{tabular}{c|ccccccc}
\hline \hline & $\begin{array}{c}\text { Não } \\
\text { aplicável } \\
(\%)\end{array}$ & $\begin{array}{c}\text { Sem } \\
\text { opinião } \\
(\%)\end{array}$ & $\begin{array}{c}\text { Nenhum } \\
\text { Risco } \\
(\%)\end{array}$ & $\begin{array}{c}\text { Pouco } \\
\text { Risco } \\
(\%)\end{array}$ & $\begin{array}{c}\text { Médio } \\
\text { Risco } \\
(\%)\end{array}$ & $\begin{array}{c}\text { Muito } \\
\text { Risco } \\
(\%)\end{array}$ & $\begin{array}{c}\text { Elevadíssimo } \\
\text { Risco } \\
(\%)\end{array}$ \\
\hline $\begin{array}{c}\text { Cabine de } \\
\text { aplicação de } \\
\text { tintas, vernizes e } \\
\text { tapa poros } \\
\text { Lixagem }\end{array}$ & 4,3 & 2,2 & 0,7 & 6,5 & 16,5 & 9,4 & 0,0 \\
Apoio & 12,2 & 7,9 & 0,7 & 4,3 & 6,5 & 6,5 & 3,6 \\
Outro & 0,7 & 0,7 & 0,7 & 2,2 & 5,8 & 2,2 & 2,2 \\
Total & 0,0 & 0,0 & 0,7 & 1,4 & 0,7 & 1,4 & 0,0 \\
\hline \hline
\end{tabular}


Tabela 32 - Respostas Sobre a Classificação do Risco associado ao manuseamento tintas/velaturas, tapa poros e vernizes sem luvas

\begin{tabular}{c|ccccccc}
\hline \hline & $\begin{array}{c}\text { Não } \\
\text { aplicável } \\
(\%)\end{array}$ & $\begin{array}{c}\text { Sem } \\
\text { opinião } \\
(\%)\end{array}$ & $\begin{array}{c}\text { Nenhum } \\
\text { Risco } \\
(\%)\end{array}$ & $\begin{array}{c}\text { Pouco } \\
\text { Risco } \\
(\%)\end{array}$ & $\begin{array}{c}\text { Médio } \\
\text { Risco } \\
(\%)\end{array}$ & $\begin{array}{c}\text { Muito } \\
\text { Risco } \\
(\%)\end{array}$ & $\begin{array}{c}\text { Elevadíssimo } \\
\text { Risco } \\
(\%)\end{array}$ \\
\hline $\begin{array}{c}\text { Cabine de } \\
\text { aplicação de } \\
\text { tintas, vernizes e } \\
\text { tapa poros } \\
\text { Lixagem }\end{array}$ & 2,8 & 0,0 & 0,0 & 2,1 & 7,1 & 17,0 & 10,6 \\
Apoio & 14,9 & 2,8 & 0,0 & 2,1 & 4,3 & 11,3 & 5,7 \\
Outro & 2,1 & 0,7 & 0,0 & 0,7 & 6,4 & 1,4 & 3,5 \\
Total & 0,0 & 0,7 & 0,0 & 0,7 & 0,0 & 1,4 & 1,4 \\
\hline \hline
\end{tabular}

Tabela 33 - Respostas Sobre a Classificação do Risco associado ao manuseamento tintas/velaturas, tapa poros e vernizes sem máscara

\begin{tabular}{c|ccccccc}
\hline \hline & $\begin{array}{c}\text { Não } \\
\text { aplicável } \\
(\%)\end{array}$ & $\begin{array}{c}\text { Sem } \\
\text { opinião } \\
(\%)\end{array}$ & $\begin{array}{c}\text { Nenhum } \\
\text { Risco } \\
(\%)\end{array}$ & $\begin{array}{c}\text { Pouco } \\
\text { Risco } \\
(\%)\end{array}$ & $\begin{array}{c}\text { Médio } \\
\text { Risco } \\
(\%)\end{array}$ & $\begin{array}{c}\text { Muito } \\
\text { Risco } \\
(\%)\end{array}$ & $\begin{array}{c}\text { Elevadíssimo } \\
\text { Risco } \\
(\%)\end{array}$ \\
\hline $\begin{array}{c}\text { Cabine de } \\
\text { aplicação de } \\
\text { tintas, vernizes e } \\
\text { tapa poros } \\
\text { Lixagem }\end{array}$ & 2,8 & 0,0 & 0,0 & 0,0 & 3,5 & 14,1 & 19,0 \\
Apoio & 14,1 & 2,1 & 0,0 & 2,1 & 0,7 & 9,9 & 12,7 \\
Outro & 2,1 & 0,7 & 0,0 & 0,7 & 4,2 & 0,7 & 6,3 \\
Total & 0,0 & 0,7 & 0,0 & 0,7 & 0,0 & 0,7 & 2,1 \\
\hline \hline
\end{tabular}


Tabela 34 - Respostas Sobre a Classificação do Risco associado a não usar equipamentos de proteção individual (EPI's) na aplicação das tintas/velaturas, tapa poros e vernizes

\begin{tabular}{c|ccccccc}
\hline \hline & $\begin{array}{c}\text { Não } \\
\text { aplicável } \\
(\%)\end{array}$ & $\begin{array}{c}\text { Sem } \\
\text { opinião } \\
(\%)\end{array}$ & $\begin{array}{c}\text { Nenhum } \\
\text { Risco } \\
(\%)\end{array}$ & $\begin{array}{c}\text { Pouco } \\
\text { Risco } \\
(\%)\end{array}$ & $\begin{array}{c}\text { Médio } \\
\text { Risco } \\
(\%)\end{array}$ & $\begin{array}{c}\text { Muito } \\
\text { Risco } \\
(\%)\end{array}$ & $\begin{array}{c}\text { Elevadíssimo } \\
\text { Risco } \\
(\%)\end{array}$ \\
\hline $\begin{array}{c}\text { Cabine de } \\
\text { aplicação de } \\
\text { tintas, vernizes e } \\
\text { tapa poros } \\
\text { Lixagem }\end{array}$ & 2,1 & 0,7 & 0,0 & 0,7 & 2,8 & 17,6 & 15,5 \\
Apoio & 11,3 & 3,5 & 0,0 & 2,1 & 2,1 & 9,9 & 12,7 \\
Outro & 0,7 & 2,8 & 0,0 & 0,0 & 2,1 & 3,5 & 5,6 \\
Total & 0,7 & 0,0 & 0,0 & 0,7 & 0,0 & 0,7 & 2,1 \\
\hline \hline
\end{tabular}




\subsection{Perceção do Risco da Exposição a tintas/velaturas, vernizes e tapa poros}

Tabela 35 - Respostas Sobre a Afirmação: "A exposição aos gases/vapores das tintas/velaturas pode ser perigosa"

\begin{tabular}{c|ccccccc}
\hline \hline & $\begin{array}{c}\text { Não } \\
\text { aplicável } \\
(\%)\end{array}$ & $\begin{array}{c}\text { Sem } \\
\text { opinião } \\
(\%)\end{array}$ & $\begin{array}{c}\text { Discordo } \\
\text { Totalmente } \\
(\%)\end{array}$ & $\begin{array}{c}\text { Discordo } \\
(\%)\end{array}$ & $\begin{array}{c}\text { Noncordo, } \\
\text { nem } \\
\text { Discordo } \\
(\%)\end{array}$ & $\begin{array}{c}\text { Concordo } \\
(\%)\end{array}$ & $\begin{array}{c}\text { Concordo } \\
\text { Totalmente } \\
(\%)\end{array}$ \\
\hline $\begin{array}{c}\text { Cabine de } \\
\text { aplicação de } \\
\text { tintas, vernizes } \\
\text { e tapa poros } \\
\text { Lixagem }\end{array}$ & 0,0 & 2,1 & 0,0 & 1,4 & 0,0 & 19,0 & 16,9 \\
Apoio & 3,5 & 2,8 & 1,4 & 0,0 & 3,5 & 15,5 & 14,8 \\
Outro & 0,7 & 0,7 & 0,0 & 0,0 & 0,0 & 9,2 & 4,2 \\
Total & 0,0 & 0,7 & 0,0 & 0,0 & 0,0 & 2,1 & 1,4 \\
\hline \hline
\end{tabular}

Tabela 36 - Respostas Sobre a Afirmação: “A exposição aos gases/vapores dos vernizes pode ser perigosa"

\begin{tabular}{c|ccccccc}
\hline \hline & $\begin{array}{c}\text { Não } \\
\text { aplicável } \\
(\%)\end{array}$ & $\begin{array}{c}\text { Sem } \\
\text { opinião } \\
(\%)\end{array}$ & $\begin{array}{c}\text { Discordo } \\
\text { Totalmente } \\
(\%)\end{array}$ & $\begin{array}{c}\text { Discordo } \\
(\%)\end{array}$ & $\begin{array}{c}\text { Nem } \\
\text { concordo, } \\
\text { nem } \\
\text { Discordo } \\
(\%)\end{array}$ & $\begin{array}{c}\text { Concordo } \\
(\%)\end{array}$ & $\begin{array}{c}\text { Concordo } \\
\text { Totalmente } \\
(\%)\end{array}$ \\
\hline $\begin{array}{c}\text { Cabine de } \\
\text { aplicação de } \\
\text { tintas, vernizes } \\
\text { e tapa poros } \\
\text { Lixagem }\end{array}$ & 0,0 & 2,1 & 0,0 & 0,7 & 0,0 & 19,7 & 16,9 \\
Apoio & 2,8 & 2,1 & 1,4 & 0,0 & 1,4 & 19,7 & 14,1 \\
Outro & 0,0 & 0,7 & 0,0 & 0,0 & 0,0 & 9,9 & 4,2 \\
Total & 0,0 & 0,7 & 0,0 & 0,0 & 0,0 & 2,1 & 1,4 \\
\hline \hline
\end{tabular}


Tabela 37 - Respostas Sobre a Afirmação: “A exposição aos gases/vapores do tapa poros pode ser perigosa"

\begin{tabular}{c|ccccccc}
\hline & $\begin{array}{c}\text { Não } \\
\text { aplicável } \\
(\%)\end{array}$ & $\begin{array}{c}\text { Sem } \\
\text { opinião } \\
(\%)\end{array}$ & $\begin{array}{c}\text { Discordo } \\
\text { Totalmente } \\
(\%)\end{array}$ & $\begin{array}{c}\text { Discordo } \\
(\%)\end{array}$ & $\begin{array}{c}\text { Nemcordo, } \\
\text { nem } \\
\text { Discordo } \\
(\%)\end{array}$ & $\begin{array}{c}\text { Concordo } \\
(\%)\end{array}$ & $\begin{array}{c}\text { Concordo } \\
\text { Totalmente } \\
(\%)\end{array}$ \\
\hline $\begin{array}{c}\text { Cabine de } \\
\text { aplicação de } \\
\text { tintas, vernizes } \\
\text { e tapa poros } \\
\text { Lixagem }\end{array}$ & 0,0 & 1,4 & 0,7 & 0,0 & 0,0 & 19,9 & 17,0 \\
Apoio & 2,8 & 1,4 & 2,1 & 1,4 & 1,4 & 22,07 & 12,1 \\
Outro & 0,7 & 0,7 & 0,0 & 0,7 & 0,7 & 8,5 & 3,5 \\
Total & 0,7 & 0,0 & 0,7 & 0,0 & 0,0 & 2,1 & 1,4 \\
\hline \hline
\end{tabular}

Tabela 38 - Respostas Sobre a Afirmação: “A exposição aos gases/vapores das tintas/velaturas é perigosa"

\begin{tabular}{c|ccccccc}
\hline \hline & $\begin{array}{c}\text { Não } \\
\text { aplicável } \\
(\%)\end{array}$ & $\begin{array}{c}\text { Sem } \\
\text { opinião } \\
(\%)\end{array}$ & $\begin{array}{c}\text { Discordo } \\
\text { Totalmente } \\
(\%)\end{array}$ & $\begin{array}{c}\text { Discordo } \\
(\%)\end{array}$ & $\begin{array}{c}\text { Nem } \\
\text { concordo, } \\
\text { nem } \\
\text { Discordo } \\
(\%)\end{array}$ & $\begin{array}{c}\text { Concordo } \\
(\%)\end{array}$ & $\begin{array}{c}\text { Concordo } \\
\text { Totalmente } \\
(\%)\end{array}$ \\
\hline $\begin{array}{c}\text { Cabine de } \\
\text { aplicação de } \\
\text { tintas, vernizes } \\
\text { e tapa poros } \\
\text { Lixagem }\end{array}$ & 0,0 & 2,1 & 0,0 & 1,4 & 1,4 & 18,3 & 16,2 \\
Apoio & 2,1 & 2,8 & 1,4 & 1,4 & 1,4 & 18,3 & 14,1 \\
Outro & 0,7 & 0,7 & 0,0 & 0,0 & 0,7 & 9,9 & 2,8 \\
Total & 0,0 & 0,7 & 0,0 & 0,0 & 0,0 & 2,1 & 1,4 \\
\hline \hline
\end{tabular}


Tabela 39 - Respostas Sobre a Afirmação: "A exposição aos gases/vapores dos vernizes é perigosa”

\begin{tabular}{c|ccccccc}
\hline \hline & $\begin{array}{c}\text { Não } \\
\text { aplicável } \\
(\%)\end{array}$ & $\begin{array}{c}\text { Sem } \\
\text { opinião } \\
(\%)\end{array}$ & $\begin{array}{c}\text { Discordo } \\
\text { Totalmente } \\
(\%)\end{array}$ & $\begin{array}{c}\text { Discordo } \\
(\%)\end{array}$ & $\begin{array}{c}\text { Nem } \\
\text { concordo, } \\
\text { nem } \\
\text { Discordo } \\
(\%)\end{array}$ & $\begin{array}{c}\text { Concordo } \\
(\%)\end{array}$ & $\begin{array}{c}\text { Concordo } \\
\text { Totalmente } \\
(\%)\end{array}$ \\
\hline $\begin{array}{c}\text { Cabine de } \\
\text { aplicação de } \\
\text { tintas, vernizes } \\
\text { e tapa poros } \\
\text { Lixagem }\end{array}$ & 0,0 & 1,4 & 0,0 & 0,0 & 0,0 & 21,3 & 17,0 \\
Apoio & 2,1 & 2,1 & 1,4 & 0,0 & 2,1 & 19,1 & 14,9 \\
Outro & 0,0 & 0,7 & 0,0 & 0,0 & 0,0 & 10,6 & 2,8 \\
Total & 0,0 & 0,0 & 0,0 & 0,0 & 0,0 & 2,8 & 1,4 \\
\hline \hline
\end{tabular}

Tabela 40 - Respostas Sobre a Afirmação: "A exposição aos gases/vapores do tapa poros é perigosa"

\begin{tabular}{c|ccccccc}
\hline & $\begin{array}{c}\text { Não } \\
\text { aplicável } \\
(\%)\end{array}$ & $\begin{array}{c}\text { Sem } \\
\text { opinião } \\
(\%)\end{array}$ & $\begin{array}{c}\text { Discordo } \\
\text { Totalmente } \\
(\%)\end{array}$ & $\begin{array}{c}\text { Discordo } \\
(\%)\end{array}$ & $\begin{array}{c}\text { Nem } \\
\text { concordo, } \\
\text { nem } \\
\text { Discordo } \\
(\%)\end{array}$ & $\begin{array}{c}\text { Concordo } \\
(\%)\end{array}$ & $\begin{array}{c}\text { Concordo } \\
\text { Totalmente } \\
(\%)\end{array}$ \\
\hline $\begin{array}{c}\text { Cabine de } \\
\text { aplicação de } \\
\text { tintas, vernizes } \\
\text { e tapa poros } \\
\text { Lixagem }\end{array}$ & 0,0 & 1,4 & 0,0 & 0,0 & 1,4 & 20,6 & 16,3 \\
Apoio & 2,1 & 2,1 & 1,4 & 0,0 & 2,1 & 20,6 & 12,8 \\
Outro & 0,7 & 0,7 & 0,0 & 0,0 & 1,4 & 8,5 & 3,5 \\
Total & 0,0 & 0,0 & 0,0 & 0,0 & 0,0 & 2,8 & 1,4 \\
\hline \hline
\end{tabular}


Tabela 41 - Respostas Sobre a Afirmação: "Não existe risco se a exposição for por pouco tempo"

\begin{tabular}{|c|c|c|c|c|c|c|c|}
\hline & $\begin{array}{c}\text { Não } \\
\text { aplicável } \\
(\%)\end{array}$ & $\begin{array}{c}\text { Sem } \\
\text { opinião } \\
(\%)\end{array}$ & $\begin{array}{c}\text { Discordo } \\
\text { Totalmente } \\
(\%)\end{array}$ & $\begin{array}{l}\text { Discordo } \\
(\%)\end{array}$ & $\begin{array}{c}\text { Nem } \\
\text { concordo, } \\
\text { nem } \\
\text { Discordo } \\
(\%)\end{array}$ & $\begin{array}{c}\text { Concordo } \\
\text { (\%) }\end{array}$ & $\begin{array}{c}\text { Concordo } \\
\text { Totalmente } \\
(\%)\end{array}$ \\
\hline $\begin{array}{c}\text { Cabine de } \\
\text { aplicação de } \\
\text { tintas, vernizes } \\
\text { e tapa poros }\end{array}$ & 0,0 & 0,7 & 3,6 & 19,3 & 3,6 & 10,7 & 2,1 \\
\hline Lixagem & 2,1 & 2,9 & 5,0 & 9,3 & 10,0 & 10,0 & 2,1 \\
\hline Apoio & 0,0 & 1,4 & 0,7 & 2,9 & 3,6 & 5,0 & 0,7 \\
\hline Outro & 0,0 & 0,0 & 0,0 & 2,1 & 0,0 & 1,4 & 0,7 \\
\hline Total & 2,1 & 5,0 & 9,3 & 33,6 & 17,1 & 27,1 & 5,7 \\
\hline
\end{tabular}

Tabela 42 - Respostas Sobre a Afirmação: "A exposição a estes produtos pode provocar doenças"

\begin{tabular}{|c|c|c|c|c|c|c|c|}
\hline & $\begin{array}{c}\text { Não } \\
\text { aplicável } \\
(\%)\end{array}$ & $\begin{array}{c}\text { Sem } \\
\text { opinião } \\
(\%)\end{array}$ & $\begin{array}{c}\text { Discordo } \\
\text { Totalmente } \\
(\%)\end{array}$ & $\begin{array}{l}\text { Discordo } \\
\text { (\%) }\end{array}$ & $\begin{array}{c}\text { Nem } \\
\text { concordo, } \\
\text { nem } \\
\text { Discordo } \\
(\%)\end{array}$ & $\begin{array}{c}\text { Concordo } \\
\text { (\%) }\end{array}$ & $\begin{array}{c}\text { Concordo } \\
\text { Totalmente } \\
(\%)\end{array}$ \\
\hline $\begin{array}{c}\text { Cabine de } \\
\text { aplicação de } \\
\text { tintas, vernizes } \\
\text { e tapa poros }\end{array}$ & 0,0 & 0,7 & 0,7 & 1,4 & 1,4 & 18,6 & 17,1 \\
\hline Lixagem & 2,1 & 1,4 & 1,4 & 0,7 & 5,0 & 15,0 & 15,7 \\
\hline Apoio & 0,0 & 0,7 & 0,0 & 0,0 & 0,7 & 8,6 & 4,3 \\
\hline Outro & 0,0 & 0,0 & 0,0 & 0,0 & 0,0 & 2,1 & 2,1 \\
\hline Total & 2,1 & 2,9 & 2,1 & 2,1 & 7,1 & 44,3 & 39,3 \\
\hline
\end{tabular}


Tabela 43 - Respostas Sobre a Afirmação: “A exposição a estes produtos não provoca danos para a saúde"

\begin{tabular}{|c|c|c|c|c|c|c|c|}
\hline & $\begin{array}{c}\text { Não } \\
\text { aplicável } \\
(\%)\end{array}$ & $\begin{array}{c}\text { Sem } \\
\text { opinião } \\
(\%)\end{array}$ & $\begin{array}{c}\text { Discordo } \\
\text { Totalmente } \\
\text { (\%) }\end{array}$ & $\begin{array}{c}\text { Discordo } \\
(\%)\end{array}$ & $\begin{array}{c}\text { Nem } \\
\text { concordo, } \\
\text { nem } \\
\text { Discordo } \\
(\%)\end{array}$ & $\begin{array}{c}\text { Concordo } \\
\text { (\%) }\end{array}$ & $\begin{array}{c}\text { Concordo } \\
\text { Totalmente } \\
\text { (\%) }\end{array}$ \\
\hline $\begin{array}{c}\text { Cabine de } \\
\text { aplicação de } \\
\text { tintas, vernizes } \\
\text { e tapa poros }\end{array}$ & 0,0 & 2,1 & 12,8 & 15,6 & 1,4 & 5,7 & 2,1 \\
\hline Lixagem & 2,1 & 1,4 & 12,1 & 12,8 & 6,4 & 2,8 & 3,5 \\
\hline Apoio & 0,0 & 0,7 & 2,8 & 6,4 & 2,1 & 0,7 & 2,1 \\
\hline Outro & 0,0 & 0,0 & 0,0 & 2,8 & 0,0 & 0,7 & 0,7 \\
\hline Total & 2,1 & 4,3 & 27,7 & 37,6 & 9,9 & 9,9 & 8,5 \\
\hline
\end{tabular}




\subsection{Utilização de Equipamentos de Proteção Individual}

Tabela 44 - Respostas Sobre a Afirmação: "Os meus colegas acham que não é necessário usar máscara na manipulação de tintas/velaturas"

\begin{tabular}{c|ccccccc}
\hline \hline & $\begin{array}{c}\text { Não } \\
\text { aplicável } \\
(\%)\end{array}$ & $\begin{array}{c}\text { Sem } \\
\text { opinião } \\
(\%)\end{array}$ & $\begin{array}{c}\text { Discordo } \\
\text { Totalmente } \\
(\%)\end{array}$ & $\begin{array}{c}\text { Discordo } \\
(\%)\end{array}$ & $\begin{array}{c}\text { Nem } \\
\text { concordo, } \\
\text { nem } \\
\text { Discordo } \\
(\%)\end{array}$ & $\begin{array}{c}\text { Concordo } \\
(\%)\end{array}$ & $\begin{array}{c}\text { Concordo } \\
\text { Totalmente } \\
(\%)\end{array}$ \\
\hline $\begin{array}{c}\text { Cabine de } \\
\text { aplicação de } \\
\text { tintas, vernizes } \\
\text { e tapa poros } \\
\text { Lixagem }\end{array}$ & 0,7 & 0,7 & 15,6 & 21,3 & 0,0 & 0,7 & 0,0 \\
Apoio & 1,4 & 4,3 & 12,8 & 20,6 & 1,4 & 1,4 & 0,0 \\
Outro & 1,4 & 1,4 & 5,0 & 6,4 & 0,0 & 0,7 & 0,0 \\
Total & 0,0 & 0,0 & 0,7 & 2,1 & 0,7 & 0,7 & 0,0 \\
\hline \hline
\end{tabular}


Tabela 45 - Respostas Sobre a Afirmação: "Os meus colegas acham que não é necessário usar máscara na manipulação do tapa poros"

\begin{tabular}{c|ccccccc}
\hline \hline & $\begin{array}{c}\text { Não } \\
\text { aplicável } \\
(\%)\end{array}$ & $\begin{array}{c}\text { Sem } \\
\text { opinião } \\
(\%)\end{array}$ & $\begin{array}{c}\text { Discordo } \\
\text { Totalmente } \\
(\%)\end{array}$ & $\begin{array}{c}\text { Discordo } \\
(\%)\end{array}$ & $\begin{array}{c}\text { Nem } \\
\text { concordo, } \\
\text { nem } \\
\text { Discordo } \\
(\%)\end{array}$ & $\begin{array}{c}\text { Concordo } \\
(\%)\end{array}$ & $\begin{array}{c}\text { Concordo } \\
\text { Totalmente } \\
(\%)\end{array}$ \\
\hline $\begin{array}{c}\text { Cabine de } \\
\text { aplicação de } \\
\text { tintas, vernizes } \\
\text { e tapa poros } \\
\text { Lixagem }\end{array}$ & 0,7 & 0,7 & 13,5 & 22,0 & 0,0 & 2,1 & 0,0 \\
$\begin{array}{c}\text { Apoio } \\
\text { Outro }\end{array}$ & 1,4 & 5,7 & 11,3 & 22,0 & 0,7 & 0,7 & 0,0 \\
Total & 1,4 & 1,4 & 4,3 & 6,4 & 0,7 & 0,7 & 0,0 \\
\hline \hline
\end{tabular}

Tabela 46 - Respostas Sobre a Afirmação: "Os meus colegas acham que não é necessário usar máscara na manipulação de vernizes"

\begin{tabular}{c|ccccccc}
\hline & $\begin{array}{c}\text { Não } \\
\text { aplicável } \\
(\%)\end{array}$ & $\begin{array}{c}\text { Sem } \\
\text { opinião } \\
(\%)\end{array}$ & $\begin{array}{c}\text { Discordo } \\
\text { Totalmente } \\
(\%)\end{array}$ & $\begin{array}{c}\text { Discordo } \\
(\%)\end{array}$ & $\begin{array}{c}\text { Nem } \\
\text { concordo, } \\
\text { nem } \\
\text { Discordo } \\
(\%)\end{array}$ & $\begin{array}{c}\text { Concordo } \\
(\%)\end{array}$ & $\begin{array}{c}\text { Concordo } \\
\text { Totalmente } \\
(\%)\end{array}$ \\
\hline $\begin{array}{c}\text { Cabine de } \\
\text { aplicação de } \\
\text { tintas, vernizes } \\
\text { e tapa poros } \\
\text { Lixagem }\end{array}$ & 0,7 & 0,7 & 14,3 & 22,1 & 0,0 & 0,7 & 0,0 \\
Apoio & 2,1 & 5,7 & 10,0 & 22,9 & 0,7 & 0,7 & 0,0 \\
Outro & 0,7 & 1,4 & 4,3 & 7,9 & 0,0 & 0,0 & 0,7 \\
Total & 0,0 & 0,0 & 0,7 & 2,1 & 0,7 & 0,7 & 0,0 \\
\hline \hline
\end{tabular}


Tabela 47 - Respostas Sobre a Afirmação: "Deram-me máscara de proteção respiratória para a manipulação de tintas/velaturas, vernizes e tapa poros"

\begin{tabular}{c|ccccccc}
\hline & $\begin{array}{c}\text { Não } \\
\text { aplicável } \\
(\%)\end{array}$ & $\begin{array}{c}\text { Sem } \\
\text { opinião } \\
(\%)\end{array}$ & $\begin{array}{c}\text { Discordo } \\
\text { Totalmente } \\
(\%)\end{array}$ & $\begin{array}{c}\text { Discordo } \\
(\%)\end{array}$ & $\begin{array}{c}\text { Nemcordo, } \\
\text { nem } \\
\text { Discordo } \\
(\%)\end{array}$ & $\begin{array}{c}\text { Concordo } \\
(\%)\end{array}$ & $\begin{array}{c}\text { Concordo } \\
\text { Totalmente } \\
(\%)\end{array}$ \\
\hline $\begin{array}{c}\text { Cabine de } \\
\text { aplicação de } \\
\text { tintas, vernizes } \\
\text { e tapa poros } \\
\text { Lixagem }\end{array}$ & 0,0 & 0,0 & 0,0 & 0,0 & 0,7 & 23,6 & 15,0 \\
Apoio & 12,1 & 2,1 & 0,0 & 0,7 & 2,1 & 17,9 & 6,4 \\
Outro & 2,1 & 1,4 & 0,0 & 0,0 & 0,7 & 9,3 & 1,4 \\
Total & 0,0 & 0,0 & 0,0 & 0,0 & 0,0 & 3,6 & 0,7 \\
\hline \hline
\end{tabular}

Tabela 48 - Respostas Sobre a Afirmação: "Penso que as máscaras que me deram são as mais adequadas"

\begin{tabular}{c|ccccccc}
\hline & $\begin{array}{c}\text { Não } \\
\text { aplicável } \\
(\%)\end{array}$ & $\begin{array}{c}\text { Sem } \\
\text { opinião } \\
(\%)\end{array}$ & $\begin{array}{c}\text { Discordo } \\
\text { Totalmente } \\
(\%)\end{array}$ & $\begin{array}{c}\text { Discordo } \\
(\%)\end{array}$ & $\begin{array}{c}\text { Nem } \\
\text { concordo, } \\
\text { nem } \\
\text { Discordo } \\
(\%)\end{array}$ & $\begin{array}{c}\text { Concordo } \\
(\%)\end{array}$ & $\begin{array}{c}\text { Concordo } \\
\text { Totalmente } \\
(\%)\end{array}$ \\
\hline $\begin{array}{c}\text { Cabine de } \\
\text { aplicação de } \\
\text { tintas, vernizes } \\
\text { e tapa poros } \\
\text { Lixagem }\end{array}$ & 0,0 & 2,1 & 0,7 & 3,6 & 10,0 & 15,7 & 7,1 \\
Apoio & 3,6 & 8,6 & 0,7 & 2,1 & 3,6 & 17,1 & 5,7 \\
Outro & 2,1 & 1,4 & 0,7 & 0,0 & 4,3 & 5,0 & 1,4 \\
Total & 0,0 & 0,7 & 0,0 & 0,7 & 0,0 & 2,9 & 0,0 \\
\hline \hline
\end{tabular}


Tabela 49 - Respostas Sobre a Afirmação: "Sei utilizar a máscara corretamente"

\begin{tabular}{|c|c|c|c|c|c|c|c|}
\hline & $\begin{array}{c}\text { Não } \\
\text { aplicável } \\
(\%)\end{array}$ & $\begin{array}{c}\text { Sem } \\
\text { opinião } \\
(\%)\end{array}$ & $\begin{array}{c}\text { Discordo } \\
\text { Totalmente } \\
\text { (\%) }\end{array}$ & $\begin{array}{c}\text { Discordo } \\
(\%)\end{array}$ & $\begin{array}{c}\text { Nem } \\
\text { concordo, } \\
\text { nem } \\
\text { Discordo } \\
(\%)\end{array}$ & $\begin{array}{c}\text { Concordo } \\
\text { (\%) }\end{array}$ & $\begin{array}{c}\text { Concordo } \\
\text { Totalmente } \\
\text { (\%) }\end{array}$ \\
\hline $\begin{array}{c}\text { Cabine de } \\
\text { aplicação de } \\
\text { tintas, vernizes } \\
\text { e tapa poros }\end{array}$ & 0,0 & 0,7 & 0,0 & 0,7 & 0,7 & 25,0 & 12,1 \\
\hline Lixagem & 4,3 & 2,9 & 0,7 & 0,7 & 1,4 & 25,0 & 6,4 \\
\hline Apoio & 2,1 & 0,0 & 0,0 & 0,0 & 0,0 & 11,4 & 1,4 \\
\hline Outro & 0,0 & 0,0 & 0,0 & 0,0 & 0,0 & 3,6 & 0,7 \\
\hline Total & 6,4 & 3,6 & 0,7 & 1,4 & 2,1 & 65,0 & 20,7 \\
\hline
\end{tabular}

Tabela 50 - Respostas Sobre a Afirmação: "As máscaras para gases e vapores são as mais adequadas para a manipulação das tintas/velaturas, vernizes e tapa poros"

\begin{tabular}{c|ccccccc}
\hline \hline & $\begin{array}{c}\text { Não } \\
\text { aplicável } \\
(\%)\end{array}$ & $\begin{array}{c}\text { Sem } \\
\text { opinião } \\
(\%)\end{array}$ & $\begin{array}{c}\text { Discordo } \\
\text { Totalmente } \\
(\%)\end{array}$ & $\begin{array}{c}\text { Discordo } \\
(\%)\end{array}$ & $\begin{array}{c}\text { Nem } \\
\text { concordo, } \\
\text { nem } \\
\text { Discordo } \\
(\%)\end{array}$ & $\begin{array}{c}\text { Concordo } \\
(\%)\end{array}$ & $\begin{array}{c}\text { Concordo } \\
\text { Totalmente } \\
(\%)\end{array}$ \\
\hline $\begin{array}{c}\text { Cabine de } \\
\text { aplicação de } \\
\text { tintas, vernizes } \\
\text { e tapa poros } \\
\text { Lixagem }\end{array}$ & 0,0 & 4,3 & 0,7 & 3,6 & 4,3 & 17,1 & 9,3 \\
$\begin{array}{c}\text { Apoio } \\
\text { Outro }\end{array}$ & 10,7 & 9,3 & 0,7 & 0,7 & 2,9 & 13,6 & 3,6 \\
Total & 0,7 & 5,0 & 0,0 & 0,7 & 2,9 & 5,7 & 0,0 \\
\hline \hline
\end{tabular}


Tabela 51 - Respostas Sobre a Afirmação: "Sei quando tenho de substituir os filtros da minha máscara"

\begin{tabular}{c|ccccccc}
\hline & $\begin{array}{c}\text { Não } \\
\text { aplicável } \\
(\%)\end{array}$ & $\begin{array}{c}\text { Sem } \\
\text { opinião } \\
(\%)\end{array}$ & $\begin{array}{c}\text { Discordo } \\
\text { Totalmente } \\
(\%)\end{array}$ & $\begin{array}{c}\text { Discordo } \\
(\%)\end{array}$ & $\begin{array}{c}\text { Nemcordo, } \\
\text { nem } \\
\text { Discordo } \\
(\%)\end{array}$ & $\begin{array}{c}\text { Concordo } \\
(\%)\end{array}$ & $\begin{array}{c}\text { Concordo } \\
\text { Totalmente } \\
(\%)\end{array}$ \\
\hline $\begin{array}{c}\text { Cabine de } \\
\text { aplicação de } \\
\text { tintas, vernizes } \\
\text { e tapa poros } \\
\text { Lixagem }\end{array}$ & 3,6 & 3,6 & 1,4 & 3,6 & 3,6 & 21,0 & 6,5 \\
Apoio & 14,5 & 6,5 & 0,0 & 0,7 & 2,2 & 15,2 & 2,2 \\
Outro & 2,9 & 2,2 & 1,4 & 0,7 & 0,7 & 8,0 & 0,0 \\
Total & 0,7 & 0,7 & 0,0 & 0,7 & 0,7 & 1,4 & 0,7 \\
\hline \hline
\end{tabular}

Tabela 52 - Respostas Sobre a Afirmação: "Sei como fazer a manutenção/limpeza da minha máscara"

\begin{tabular}{c|ccccccc}
\hline \hline & $\begin{array}{c}\text { Não } \\
\text { aplicável } \\
(\%)\end{array}$ & $\begin{array}{c}\text { Sem } \\
\text { opinião } \\
(\%)\end{array}$ & $\begin{array}{c}\text { Discordo } \\
\text { Totalmente } \\
(\%)\end{array}$ & $\begin{array}{c}\text { Discordo } \\
(\%)\end{array}$ & $\begin{array}{c}\text { Nem } \\
\text { concordo, } \\
\text { nem } \\
\text { Discordo } \\
(\%)\end{array}$ & $\begin{array}{c}\text { Concordo } \\
(\%)\end{array}$ & $\begin{array}{c}\text { Concordo } \\
\text { Totalmente } \\
(\%)\end{array}$ \\
\hline $\begin{array}{c}\text { Cabine de } \\
\text { aplicação de } \\
\text { tintas, vernizes } \\
\text { e tapa poros } \\
\text { Lixagem }\end{array}$ & 2,2 & 3,6 & 0,0 & 1,5 & 3,6 & 21,2 & 8,0 \\
Apoio & 8,8 & 5,8 & 0,7 & 0,0 & 1,5 & 19,0 & 4,4 \\
Outro & 3,6 & 2,2 & 0,0 & 0,7 & 0,7 & 5,8 & 2,2 \\
Total & 0,7 & 0,7 & 0,0 & 0,0 & 0,7 & 1,5 & 0,7 \\
\hline \hline
\end{tabular}


Tabela 53 - Respostas Sobre a Afirmação: "Por vezes a minha máscara fica estragada"

\begin{tabular}{|c|c|c|c|c|c|c|c|}
\hline & $\begin{array}{c}\text { Não } \\
\text { aplicável } \\
(\%)\end{array}$ & $\begin{array}{c}\text { Sem } \\
\text { opinião } \\
(\%)\end{array}$ & $\begin{array}{c}\text { Discordo } \\
\text { Totalmente } \\
(\%)\end{array}$ & $\begin{array}{c}\text { Discordo } \\
(\%)\end{array}$ & $\begin{array}{c}\text { Nem } \\
\text { concordo, } \\
\text { nem } \\
\text { Discordo } \\
(\%)\end{array}$ & $\begin{array}{l}\text { Concordo } \\
\text { (\%) }\end{array}$ & $\begin{array}{c}\text { Concordo } \\
\text { Totalmente } \\
(\%)\end{array}$ \\
\hline $\begin{array}{c}\text { Cabine de } \\
\text { aplicação de } \\
\text { tintas, vernizes } \\
\text { e tapa poros }\end{array}$ & 2,2 & 1,5 & 0,0 & 3,2 & 0,7 & 27,9 & 5,1 \\
\hline Lixagem & 2,9 & 2,9 & 0,0 & 1,5 & 3,7 & 22,8 & 6,6 \\
\hline Apoio & 2,2 & 1,5 & 0,0 & 0,7 & 0,7 & 10,3 & 0,0 \\
\hline Outro & 0,0 & 0,0 & 0,0 & 0,7 & 0,0 & 2,9 & 0,7 \\
\hline Total & 7,4 & 5,9 & 0,0 & 5,1 & 5,1 & 64,0 & 12,5 \\
\hline
\end{tabular}

Tabela 54 - Respostas Sobre a Afirmação: "Quando a minha máscara está danificada substituo-a imediatamente"

\begin{tabular}{c|ccccccc}
\hline \hline & $\begin{array}{c}\text { Não } \\
\text { aplicável } \\
(\%)\end{array}$ & $\begin{array}{c}\text { Sem } \\
\text { opinião } \\
(\%)\end{array}$ & $\begin{array}{c}\text { Discordo } \\
\text { Totalmente } \\
(\%)\end{array}$ & $\begin{array}{c}\text { Discordo } \\
(\%)\end{array}$ & $\begin{array}{c}\text { Nem } \\
\text { concordo, } \\
\text { nem } \\
\text { Discordo } \\
(\%)\end{array}$ & $\begin{array}{c}\text { Concordo } \\
(\%)\end{array}$ & $\begin{array}{c}\text { Concordo } \\
\text { Totalmente } \\
(\%)\end{array}$ \\
\hline $\begin{array}{c}\text { Cabine de } \\
\text { aplicação de } \\
\text { tintas, vernizes } \\
\text { e tapa poros } \\
\text { Lixagem }\end{array}$ & 1,4 & 0,0 & 0,0 & 1,4 & 0,0 & 23,0 & 13,7 \\
$\begin{array}{c}\text { Apoio } \\
\text { Outro }\end{array}$ & 3,6 & 2,2 & 0,0 & 1,4 & 2,9 & 19,4 & 11,5 \\
Total & 2,9 & 0,0 & 0,0 & 0,0 & 0,7 & 7,9 & 3,6 \\
\hline \hline
\end{tabular}


Tabela 55 - Respostas Sobre a Afirmação: "Preciso saber mais para utilizar corretamente a máscara"

\begin{tabular}{c|ccccccc}
\hline & $\begin{array}{c}\text { Não } \\
\text { aplicável } \\
(\%)\end{array}$ & $\begin{array}{c}\text { Sem } \\
\text { opinião } \\
(\%)\end{array}$ & $\begin{array}{c}\text { Discordo } \\
\text { Totalmente } \\
(\%)\end{array}$ & $\begin{array}{c}\text { Discordo } \\
(\%)\end{array}$ & $\begin{array}{c}\text { Nemcordo, } \\
\text { nem } \\
\text { Discordo } \\
(\%)\end{array}$ & $\begin{array}{c}\text { Concordo } \\
(\%)\end{array}$ & $\begin{array}{c}\text { Concordo } \\
\text { Totalmente } \\
(\%)\end{array}$ \\
\hline $\begin{array}{c}\text { Cabine de } \\
\text { aplicação de } \\
\text { tintas, vernizes } \\
\text { e tapa poros } \\
\text { Lixagem }\end{array}$ & 1,5 & 3,7 & 1,5 & 14,7 & 8,8 & 8,8 & 1,5 \\
Apoio & 3,7 & 7,4 & 1,5 & 11,0 & 6,6 & 8,1 & 1,5 \\
Outro & 1,5 & 2,2 & 0,0 & 2,9 & 2,9 & 5,1 & 0,7 \\
Total & 0,0 & 0,0 & 0,0 & 2,9 & 0,7 & 0,7 & 0,0 \\
\hline \hline
\end{tabular}

Tabela 56 - Respostas Sobre a Afirmação: "Quando a minha máscara está estragada espero que termine o trabalho para a substituir"

\begin{tabular}{c|ccccccc}
\hline & $\begin{array}{c}\text { Não } \\
\text { aplicável } \\
(\%)\end{array}$ & $\begin{array}{c}\text { Sem } \\
\text { opinião } \\
(\%)\end{array}$ & $\begin{array}{c}\text { Discordo } \\
\text { Totalmente } \\
(\%)\end{array}$ & $\begin{array}{c}\text { Discordo } \\
(\%)\end{array}$ & $\begin{array}{c}\text { Nencordo, } \\
\text { nem } \\
\text { Discordo } \\
(\%)\end{array}$ & $\begin{array}{c}\text { Concordo } \\
(\%)\end{array}$ & $\begin{array}{c}\text { Concordo } \\
\text { Totalmente } \\
(\%)\end{array}$ \\
\hline $\begin{array}{c}\text { Cabine de } \\
\text { aplicação de } \\
\text { tintas, vernizes } \\
\text { e tapa poros } \\
\text { Lixagem }\end{array}$ & 1,5 & 0,0 & 5,1 & 25,0 & 5,1 & 2,9 & 0,7 \\
Apoio & 5,1 & 1,5 & 5,1 & 19,9 & 3,7 & 2,2 & 2,9 \\
Outro & 2,2 & 0,0 & 2,2 & 7,4 & 0,7 & 1,5 & 0,7 \\
Total & 0,0 & 0,0 & 0,7 & 2,9 & 0,0 & 0,7 & 0,0 \\
\hline \hline
\end{tabular}


Tabela 57 - Respostas Sobre a Afirmação: "Sei quantas vezes posso usar o filtro da minha máscara"

\begin{tabular}{c|ccccccc}
\hline \hline & $\begin{array}{c}\text { Não } \\
\text { aplicável } \\
(\%)\end{array}$ & $\begin{array}{c}\text { Sem } \\
\text { opinião } \\
(\%)\end{array}$ & $\begin{array}{c}\text { Discordo } \\
\text { Totalmente } \\
(\%)\end{array}$ & $\begin{array}{c}\text { Discordo } \\
(\%)\end{array}$ & $\begin{array}{c}\text { Nem } \\
\text { concordo, } \\
\text { nem } \\
\text { Discordo } \\
(\%)\end{array}$ & $\begin{array}{c}\text { Concordo } \\
(\%)\end{array}$ & $\begin{array}{c}\text { Concordo } \\
\text { Totalmente } \\
(\%)\end{array}$ \\
\hline $\begin{array}{c}\text { Cabine de } \\
\text { aplicação de } \\
\text { tintas, vernizes } \\
\text { e tapa poros } \\
\text { Lixagem }\end{array}$ & 5,1 & 5,8 & 0,7 & 2,9 & 8,0 & 13,9 & 3,6 \\
Apoio & 14,6 & 10,9 & 1,5 & 1,5 & 2,9 & 8,8 & 0,7 \\
Outro & 2,9 & 2,9 & 0,7 & 2,2 & 2,9 & 2,2 & 0,7 \\
Total & 0,7 & 0,7 & 0,0 & 0,7 & 0,7 & 0,7 & 0,7 \\
\hline \hline
\end{tabular}

Tabela 58 - Respostas Sobre a Afirmação: "Utilizo a máscara que estiver disponível"

\begin{tabular}{c|ccccccc}
\hline \hline & $\begin{array}{c}\text { Não } \\
\text { aplicável } \\
(\%)\end{array}$ & $\begin{array}{c}\text { Sem } \\
\text { opinião } \\
(\%)\end{array}$ & $\begin{array}{c}\text { Discordo } \\
\text { Totalmente } \\
(\%)\end{array}$ & $\begin{array}{c}\text { Nem } \\
\text { Discordo } \\
(\%)\end{array}$ & $\begin{array}{c}\text { concordo, } \\
\text { nem } \\
\text { Discordo } \\
(\%)\end{array}$ & $\begin{array}{c}\text { Concordo } \\
(\%)\end{array}$ & $\begin{array}{c}\text { Concordo } \\
\text { Totalmente } \\
(\%)\end{array}$ \\
\hline $\begin{array}{c}\text { Cabine de } \\
\text { aplicação de } \\
\text { tintas, vernizes } \\
\text { e tapa poros }\end{array}$ & 1,4 & 1,4 & 8,7 & 19,6 & 1,4 & 5,8 & 0,7 \\
Lixagem & 8,0 & 4,3 & 5,1 & 14,5 & 3,6 & 3,6 & 2,2 \\
Apoio & 4,3 & 0,7 & 2,9 & 5,1 & 0,7 & 0,7 & 0,7 \\
Outro & 0,7 & 0,0 & 1,4 & 1,4 & 0,0 & 0,7 & 0,0 \\
Total & 14,5 & 6,5 & 18,1 & 40,6 & 5,8 & 10,9 & 3,6 \\
\hline \hline
\end{tabular}


Tabela 59 - Respostas Sobre a Afirmação: "Sei distinguir os vários tipos de máscaras de proteção"

\begin{tabular}{|c|c|c|c|c|c|c|c|}
\hline & $\begin{array}{c}\text { Não } \\
\text { aplicável } \\
(\%)\end{array}$ & $\begin{array}{c}\text { Sem } \\
\text { opinião } \\
(\%)\end{array}$ & $\begin{array}{c}\text { Discordo } \\
\text { Totalmente } \\
(\%)\end{array}$ & $\begin{array}{l}\text { Discordo } \\
(\%)\end{array}$ & $\begin{array}{c}\text { Nem } \\
\text { concordo, } \\
\text { nem } \\
\text { Discordo } \\
(\%)\end{array}$ & $\begin{array}{l}\text { Concordo } \\
\text { (\%) }\end{array}$ & $\begin{array}{c}\text { Concordo } \\
\text { Totalmente } \\
(\%)\end{array}$ \\
\hline $\begin{array}{c}\text { Cabine de } \\
\text { aplicação de } \\
\text { tintas, vernizes } \\
\text { e tapa poros }\end{array}$ & 1,5 & 6,7 & 0,7 & 3,0 & 9,6 & 12,6 & 5,2 \\
\hline Lixagem & 5,9 & 10,4 & 1,5 & 0,7 & 4,4 & 14,1 & 4,4 \\
\hline Apoio & 3,0 & 5,2 & 0,0 & 1,5 & 1,5 & 4,4 & 0,0 \\
\hline Outro & 0,0 & 0,7 & 0,0 & 0,0 & 0,0 & 3,0 & 0,0 \\
\hline Total & 10,4 & 23,0 & 2,2 & 5,2 & 15,6 & 34,1 & 9,6 \\
\hline
\end{tabular}

Tabela 60 - Respostas Sobre a Afirmação: "Preciso aprender mais para escolher a máscara de proteção mais eficaz"

\begin{tabular}{c|ccccccc}
\hline & $\begin{array}{c}\text { Não } \\
\text { aplicável } \\
(\%)\end{array}$ & $\begin{array}{c}\text { Sem } \\
\text { opinião } \\
(\%)\end{array}$ & $\begin{array}{c}\text { Discordo } \\
\text { Totalmente } \\
(\%)\end{array}$ & $\begin{array}{c}\text { Discordo } \\
(\%)\end{array}$ & $\begin{array}{c}\text { Nemcordo, } \\
\text { nem } \\
\text { Discordo } \\
(\%)\end{array}$ & $\begin{array}{c}\text { Concordo } \\
(\%)\end{array}$ & $\begin{array}{c}\text { Concordo } \\
\text { Totalmente } \\
(\%)\end{array}$ \\
\hline $\begin{array}{c}\text { Cabine de } \\
\text { aplicação de } \\
\text { tintas, vernizes } \\
\text { e tapa poros } \\
\text { Lixagem }\end{array}$ & 0,7 & 2,2 & 1,5 & 11,8 & 11,0 & 8,8 & 3,7 \\
Apoio & 5,1 & 8,8 & 1,5 & 6,6 & 3,7 & 12,5 & 2,9 \\
Outro & 2,2 & 1,5 & 0,7 & 2,9 & 2,9 & 4,4 & 0,7 \\
Total & 0,0 & 1,5 & 0,7 & 0,0 & 0,7 & 0,7 & 0,0 \\
\hline \hline
\end{tabular}


Tabela 61 - Respostas Sobre a Afirmação: "Gosto do cheiro das tintas/velaturas"

\begin{tabular}{c|ccccccc}
\hline \hline & $\begin{array}{c}\text { Não } \\
\text { aplicável } \\
(\%)\end{array}$ & $\begin{array}{c}\text { Sem } \\
\text { opinião } \\
(\%)\end{array}$ & $\begin{array}{c}\text { Discordo } \\
\text { Totalmente } \\
(\%)\end{array}$ & $\begin{array}{c}\text { Discordo } \\
(\%)\end{array}$ & $\begin{array}{c}\text { Nem } \\
\text { concordo, } \\
\text { nem } \\
\text { Discordo } \\
(\%)\end{array}$ & $\begin{array}{c}\text { Concordo } \\
(\%)\end{array}$ & $\begin{array}{c}\text { Concordo } \\
\text { Totalmente } \\
(\%)\end{array}$ \\
\hline $\begin{array}{c}\text { Cabine de } \\
\text { aplicação de } \\
\text { tintas, vernizes } \\
\text { e tapa poros } \\
\text { Lixagem }\end{array}$ & 0,0 & 2,9 & 10,8 & 18,0 & 4,3 & 2,9 & 0,7 \\
Apoio & 3,6 & 5,8 & 9,4 & 13,7 & 7,2 & 0,7 & 1,4 \\
Outro & 3,6 & 2,2 & 2,2 & 4,3 & 1,4 & 0,7 & 0,7 \\
Total & 0,0 & 0,0 & 2,2 & 1,4 & 0,0 & 0,0 & 0,0 \\
\hline \hline
\end{tabular}

Tabela 62 - Respostas Sobre a Afirmação: "Gosto do cheiro do tapa poros"

\begin{tabular}{c|ccccccc}
\hline \hline & $\begin{array}{c}\text { Não } \\
\text { aplicável } \\
(\%)\end{array}$ & $\begin{array}{c}\text { Sem } \\
\text { opinião } \\
(\%)\end{array}$ & $\begin{array}{c}\text { Discordo } \\
\text { Tolmente } \\
(\%)\end{array}$ & $\begin{array}{c}\text { Discordo } \\
(\%)\end{array}$ & $\begin{array}{c}\text { Nem } \\
\text { concordo, } \\
\text { nem } \\
\text { Discordo } \\
(\%)\end{array}$ & $\begin{array}{c}\text { Concordo } \\
(\%)\end{array}$ & $\begin{array}{c}\text { Concordo } \\
\text { Totalmente } \\
(\%)\end{array}$ \\
\hline $\begin{array}{c}\text { Cabine de } \\
\text { aplicação de } \\
\text { tintas, vernizes } \\
\text { e tapa poros } \\
\text { Lixagem }\end{array}$ & 0,0 & 4,3 & 10,9 & 18,1 & 5,1 & 1,4 & 0,0 \\
$\begin{array}{c}\text { Apoio } \\
\text { Outro }\end{array}$ & 3,6 & 4,3 & 10,1 & 14,5 & 5,8 & 2,2 & 0,7 \\
Total & 3,6 & 1,4 & 2,2 & 4,3 & 2,2 & 0,7 & 0,7 \\
\hline \hline
\end{tabular}


Tabela 63 - Respostas Sobre a Afirmação: "Gosto do cheiro dos vernizes"

\begin{tabular}{c|ccccccc}
\hline \hline & $\begin{array}{c}\text { Não } \\
\text { aplicável } \\
(\%)\end{array}$ & $\begin{array}{c}\text { Sem } \\
\text { opinião } \\
(\%)\end{array}$ & $\begin{array}{c}\text { Discordo } \\
\text { Totmente } \\
(\%)\end{array}$ & $\begin{array}{c}\text { Discordo } \\
(\%)\end{array}$ & $\begin{array}{c}\text { Nem } \\
\text { concordo, } \\
\text { nem } \\
\text { Discordo } \\
(\%)\end{array}$ & $\begin{array}{c}\text { Concordo } \\
(\%)\end{array}$ & $\begin{array}{c}\text { Concordo } \\
\text { Totalmente } \\
(\%)\end{array}$ \\
\hline $\begin{array}{c}\text { Cabine de } \\
\text { aplicação de } \\
\text { tintas, vernizes } \\
\text { e tapa poros } \\
\text { Lixagem }\end{array}$ & 0,0 & 3,6 & 10,8 & 18,7 & 5,0 & 1,4 & 0,0 \\
$\begin{array}{c}\text { Apoio } \\
\text { Outro }\end{array}$ & 3,6 & 5,0 & 10,1 & 14,4 & 5,8 & 1,4 & 1,4 \\
Total & 2,9 & 2,2 & 2,2 & 4,3 & 2,9 & 0,0 & 0,7 \\
\hline \hline
\end{tabular}

Tabela 64 - Respostas Sobre a Afirmação: “Deram-me luvas de proteção para a manipulação de tintas/velaturas, vernizes e tapa poros"

\begin{tabular}{c|ccccccc}
\hline & $\begin{array}{c}\text { Não } \\
\text { aplicável } \\
(\%)\end{array}$ & $\begin{array}{c}\text { Sem } \\
\text { opinião } \\
(\%)\end{array}$ & $\begin{array}{c}\text { Discordo } \\
\text { Totalmente } \\
(\%)\end{array}$ & $\begin{array}{c}\text { Discordo } \\
(\%)\end{array}$ & $\begin{array}{c}\text { Nem } \\
\text { concordo, } \\
\text { nem } \\
\text { Discordo } \\
(\%)\end{array}$ & $\begin{array}{c}\text { Concordo } \\
(\%)\end{array}$ & $\begin{array}{c}\text { Concordo } \\
\text { Totalmente } \\
(\%)\end{array}$ \\
\hline $\begin{array}{c}\text { Cabine de } \\
\text { aplicação de } \\
\text { tintas, vernizes } \\
\text { e tapa poros } \\
\text { Lixagem }\end{array}$ & 1,4 & 0,0 & 0,0 & 0,7 & 0,7 & 27,5 & 9,9 \\
Apoio & 14,8 & 2,1 & 0,7 & 1,4 & 1,4 & 16,9 & 4,9 \\
Outro & 2,1 & 0,0 & 0,0 & 0,0 & 0,0 & 11,3 & 0,0 \\
Total & 0,7 & 0,0 & 0,0 & 0,0 & 0,0 & 2,1 & 1,4 \\
\hline \hline
\end{tabular}


Tabela 65 - Respostas Sobre a Afirmação: “Uso as luvas para a manipulação de tintas/velaturas, vernizes e tapa poros"

\begin{tabular}{c|ccccccc}
\hline \hline & $\begin{array}{c}\text { Não } \\
\text { aplicável } \\
(\%)\end{array}$ & $\begin{array}{c}\text { Sem } \\
\text { opinião } \\
(\%)\end{array}$ & $\begin{array}{c}\text { Discordo } \\
\text { Totalmente } \\
(\%)\end{array}$ & $\begin{array}{c}\text { Discordo } \\
(\%)\end{array}$ & $\begin{array}{c}\text { Nem } \\
\text { concordo, } \\
\text { nem } \\
\text { Discordo } \\
(\%)\end{array}$ & $\begin{array}{c}\text { Concordo } \\
(\%)\end{array}$ & $\begin{array}{c}\text { Concordo } \\
\text { Totalmente } \\
(\%)\end{array}$ \\
\hline $\begin{array}{c}\text { Cabine de } \\
\text { aplicação de } \\
\text { tintas, vernizes } \\
\text { e tapa poros } \\
\text { Lixagem }\end{array}$ & 0,7 & 0,0 & 0,0 & 0,7 & 2,1 & 24,3 & 11,4 \\
Apoio & 15,7 & 2,9 & 0,7 & 0,7 & 2,1 & 13,6 & 5,7 \\
Outro & 2,1 & 0,0 & 0,0 & 0,0 & 0,0 & 12,1 & 0,7 \\
Total & 0,7 & 0,0 & 0,0 & 0,0 & 0,0 & 2,1 & 1,4 \\
\hline \hline
\end{tabular}

Tabela 66 - Respostas Sobre a Afirmação: "O contato das tintas/velaturas, vernizes e tapa poros com a pele é perigoso"

\begin{tabular}{|c|c|c|c|c|c|c|c|}
\hline & $\begin{array}{c}\text { Não } \\
\text { aplicável } \\
(\%)\end{array}$ & $\begin{array}{c}\text { Sem } \\
\text { opinião } \\
(\%)\end{array}$ & $\begin{array}{c}\text { Discordo } \\
\text { Totalmente } \\
(\%)\end{array}$ & $\begin{array}{c}\text { Discordo } \\
(\%)\end{array}$ & $\begin{array}{c}\text { Nem } \\
\text { concordo, } \\
\text { nem } \\
\text { Discordo } \\
(\%)\end{array}$ & $\begin{array}{l}\text { Concordo } \\
\text { (\%) }\end{array}$ & $\begin{array}{c}\text { Concordo } \\
\text { Totalmente } \\
\text { (\%) }\end{array}$ \\
\hline $\begin{array}{c}\text { Cabine de } \\
\text { aplicação de } \\
\text { tintas, vernizes } \\
\text { e tapa poros }\end{array}$ & 0,0 & 0,0 & 0,0 & 2,1 & 0,0 & 21,1 & 16,2 \\
\hline Lixagem & 4,2 & 3,5 & 0,7 & 0,0 & 3,5 & 14,1 & 15,5 \\
\hline Apoio & 0,7 & 0,7 & 0,0 & 0,0 & 0,7 & 10,6 & 2,1 \\
\hline Outro & 0,0 & 0,0 & 0,0 & 0,0 & 0,0 & 2,8 & 1,4 \\
\hline Total & 4,9 & 4,2 & 0,7 & 2,1 & 4,2 & 48,6 & 35,2 \\
\hline
\end{tabular}


Tabela 67 - Respostas Sobre a Afirmação: "Penso que as luvas que me deram são as mais adequadas"

\begin{tabular}{c|ccccccc}
\hline \hline & $\begin{array}{c}\text { Não } \\
\text { aplicável } \\
(\%)\end{array}$ & $\begin{array}{c}\text { Sem } \\
\text { opinião } \\
(\%)\end{array}$ & $\begin{array}{c}\text { Discordo } \\
\text { Totalmente } \\
(\%)\end{array}$ & $\begin{array}{c}\text { Discordo } \\
(\%)\end{array}$ & $\begin{array}{c}\text { Nem } \\
\text { concordo, } \\
\text { nem } \\
\text { Discordo } \\
(\%)\end{array}$ & $\begin{array}{c}\text { Concordo } \\
(\%)\end{array}$ & $\begin{array}{c}\text { Concordo } \\
\text { Totalmente } \\
(\%)\end{array}$ \\
\hline $\begin{array}{c}\text { Cabine de } \\
\text { aplicação de } \\
\text { tintas, vernizes } \\
\text { e tapa poros } \\
\text { Lixagem }\end{array}$ & 1,4 & 1,4 & 0,0 & 1,4 & 5,7 & 23,6 & 6,4 \\
$\begin{array}{c}\text { Apoio } \\
\text { Outro }\end{array}$ & 1,4 & 6,4 & 1,4 & 0,0 & 6,4 & 22,1 & 3,6 \\
Total & 0,7 & 2,9 & 0,7 & 0,7 & 0,7 & 8,6 & 0,7 \\
\hline \hline
\end{tabular}

Tabela 68 - Respostas Sobre a Afirmação: "Sei utilizar as luvas corretamente"

\begin{tabular}{c|ccccccc}
\hline & $\begin{array}{c}\text { Não } \\
\text { aplicável } \\
(\%)\end{array}$ & $\begin{array}{c}\text { Sem } \\
\text { opinião } \\
(\%)\end{array}$ & $\begin{array}{c}\text { Discordo } \\
\text { Totalmente } \\
(\%)\end{array}$ & $\begin{array}{c}\text { Discordo } \\
(\%)\end{array}$ & $\begin{array}{c}\text { Nem } \\
\text { concordo, } \\
\text { nem } \\
\text { Discordo } \\
(\%)\end{array}$ & $\begin{array}{c}\text { Concordo } \\
(\%)\end{array}$ & $\begin{array}{c}\text { Concordo } \\
\text { Totalmente } \\
(\%)\end{array}$ \\
\hline $\begin{array}{c}\text { Cabine de } \\
\text { aplicação de } \\
\text { tintas, vernizes } \\
\text { e tapa poros } \\
\text { Lixagem }\end{array}$ & 0,0 & 0,0 & 0,0 & 0,0 & 0,0 & 28,4 & 11,3 \\
Apoio & 2,1 & 2,8 & 0,0 & 0,7 & 2,1 & 21,3 & 12,1 \\
Outro & 0,7 & 0,7 & 0,0 & 0,0 & 0,0 & 9,9 & 3,5 \\
Total & 0,0 & 0,0 & 0,7 & 0,0 & 0,0 & 2,8 & 0,7 \\
\hline \hline
\end{tabular}


Tabela 69 - Respostas Sobre a Afirmação: "Quando as luvas estão danificadas substituo-as imediatamente"

\begin{tabular}{c|ccccccc}
\hline \hline & $\begin{array}{c}\text { Não } \\
\text { aplicável } \\
(\%)\end{array}$ & $\begin{array}{c}\text { Sem } \\
\text { opinião } \\
(\%)\end{array}$ & $\begin{array}{c}\text { Discordo } \\
\text { Totalmente } \\
(\%)\end{array}$ & $\begin{array}{c}\text { Discordo } \\
(\%)\end{array}$ & $\begin{array}{c}\text { Nem } \\
\text { concordo, } \\
\text { nem } \\
\text { Discordo } \\
(\%)\end{array}$ & $\begin{array}{c}\text { Concordo } \\
(\%)\end{array}$ & $\begin{array}{c}\text { Concordo } \\
\text { Totalmente } \\
(\%)\end{array}$ \\
\hline $\begin{array}{c}\text { Cabine de } \\
\text { aplicação de } \\
\text { tintas, vernizes } \\
\text { e tapa poros } \\
\text { Lixagem }\end{array}$ & 0,0 & 0,0 & 0,0 & 0,0 & 1,4 & 24,6 & 13,4 \\
Apoio & 1,4 & 2,8 & 0,0 & 1,4 & 0,7 & 25,4 & 9,9 \\
Outro & 0,7 & 0,0 & 0,0 & 0,7 & 0,0 & 9,2 & 4,2 \\
Total & 0,7 & 0,0 & 0,0 & 0,0 & 0,0 & 2,1 & 1,4 \\
\hline \hline
\end{tabular}

Tabela 70 - Respostas Sobre a Afirmação: "Quando preciso tenho sempre disponível luvas de substituição"

\begin{tabular}{|c|c|c|c|c|c|c|c|}
\hline & $\begin{array}{c}\text { Não } \\
\text { aplicável } \\
(\%)\end{array}$ & $\begin{array}{c}\text { Sem } \\
\text { opinião } \\
(\%)\end{array}$ & $\begin{array}{c}\text { Discordo } \\
\text { Totalmente } \\
(\%)\end{array}$ & $\begin{array}{c}\text { Discordo } \\
(\%)\end{array}$ & $\begin{array}{c}\text { Nem } \\
\text { concordo, } \\
\text { nem } \\
\text { Discordo } \\
(\%)\end{array}$ & $\begin{array}{l}\text { Concordo } \\
\text { (\%) }\end{array}$ & $\begin{array}{c}\text { Concordo } \\
\text { Totalmente } \\
\text { (\%) }\end{array}$ \\
\hline $\begin{array}{c}\text { Cabine de } \\
\text { aplicação de } \\
\text { tintas, vernizes } \\
\text { e tapa poros }\end{array}$ & 0,0 & 0,0 & 0,0 & 2,1 & 0,7 & 21,3 & 15,6 \\
\hline Lixagem & 1,4 & 0,7 & 1,4 & 0,7 & 2,8 & 21,3 & 12,8 \\
\hline Apoio & 0,7 & 0,0 & 0,7 & 0,0 & 2,1 & 9,9 & 1,4 \\
\hline Outro & 0,0 & 0,0 & 0,0 & 0,0 & 0,0 & 2,8 & 1,4 \\
\hline Total & 2,1 & 0,7 & 2,1 & 2,8 & 5,7 & 55,3 & 31,2 \\
\hline
\end{tabular}


Tabela 71 - Respostas Sobre a Afirmação: "Uso sempre as luvas"

\begin{tabular}{c|ccccccc}
\hline \hline & $\begin{array}{c}\text { Não } \\
\text { aplicável } \\
(\%)\end{array}$ & $\begin{array}{c}\text { Sem } \\
\text { opinião } \\
(\%)\end{array}$ & $\begin{array}{c}\text { Discordo } \\
\text { Totalmente } \\
(\%)\end{array}$ & $\begin{array}{c}\text { Discordo } \\
(\%)\end{array}$ & $\begin{array}{c}\text { Nem } \\
\text { concordo, } \\
\text { nem } \\
\text { Discordo } \\
(\%)\end{array}$ & $\begin{array}{c}\text { Concordo } \\
(\%)\end{array}$ & $\begin{array}{c}\text { Concordo } \\
\text { Totalmente } \\
(\%)\end{array}$ \\
\hline $\begin{array}{c}\text { Cabine de } \\
\text { aplicação de } \\
\text { tintas, vernizes } \\
\text { e tapa poros } \\
\text { Lixagem }\end{array}$ & 0,0 & 0,0 & 0,0 & 2,8 & 1,4 & 20,6 & 14,9 \\
$\begin{array}{c}\text { Apoio } \\
\text { Outro }\end{array}$ & 1,4 & 1,4 & 0,0 & 2,8 & 5,0 & 18,4 & 12,1 \\
Total & 0,7 & 0,7 & 0,0 & 0,7 & 0,0 & 9,9 & 2,8 \\
\hline \hline
\end{tabular}

Tabela 72 - Respostas Sobre a Afirmação: "Deram-me fato de proteção para a manipulação de tintas/velaturas, vernizes e tapa poros"

\begin{tabular}{c|ccccccc}
\hline & $\begin{array}{c}\text { Não } \\
\text { aplicável } \\
(\%)\end{array}$ & $\begin{array}{c}\text { Sem } \\
\text { opinião } \\
(\%)\end{array}$ & $\begin{array}{c}\text { Discordo } \\
\text { Totalmente } \\
(\%)\end{array}$ & $\begin{array}{c}\text { Discordo } \\
(\%)\end{array}$ & $\begin{array}{c}\text { Nem } \\
\text { concordo, } \\
\text { nem } \\
\text { Discordo } \\
(\%)\end{array}$ & $\begin{array}{c}\text { Concordo } \\
(\%)\end{array}$ & $\begin{array}{c}\text { Concordo } \\
\text { Totalmente } \\
(\%)\end{array}$ \\
\hline $\begin{array}{c}\text { Cabine de } \\
\text { aplicação de } \\
\text { tintas, vernizes } \\
\text { e tapa poros } \\
\text { Lixagem }\end{array}$ & 3,6 & 5,0 & 1,4 & 2,9 & 3,6 & 13,6 & 10,0 \\
Apoio & 23,6 & 2,9 & 2,1 & 0,7 & 2,9 & 5,0 & 3,6 \\
Outro & 2,1 & 2,9 & 2,1 & 1,4 & 1,4 & 3,6 & 1,4 \\
Total & 2,1 & 0,0 & 0,0 & 0,7 & 0,0 & 0,7 & 0,7 \\
\hline \hline
\end{tabular}


Tabela 73 - Respostas Sobre a Afirmação: "Penso que o fato que deram para a manipulação de tintas/velaturas, vernizes e tapa poros é o mais adequado"

\begin{tabular}{c|ccccccc}
\hline \hline & $\begin{array}{c}\text { Não } \\
\text { aplicável } \\
(\%)\end{array}$ & $\begin{array}{c}\text { Sem } \\
\text { opinião } \\
(\%)\end{array}$ & $\begin{array}{c}\text { Discordo } \\
\text { Totalmente } \\
(\%)\end{array}$ & $\begin{array}{c}\text { Discordo } \\
(\%)\end{array}$ & $\begin{array}{c}\text { Nem } \\
\text { concordo, } \\
\text { nem } \\
\text { Discordo } \\
(\%)\end{array}$ & $\begin{array}{c}\text { Concordo } \\
(\%)\end{array}$ & $\begin{array}{c}\text { Concordo } \\
\text { Totalmente } \\
(\%)\end{array}$ \\
\hline $\begin{array}{c}\text { Cabine de } \\
\text { aplicação de } \\
\text { tintas, vernizes } \\
\text { e tapa poros } \\
\text { Lixagem }\end{array}$ & 5,7 & 5,0 & 1,4 & 2,1 & 5,0 & 13,5 & 7,1 \\
$\begin{array}{c}\text { Apoio } \\
\text { Outro }\end{array}$ & 25,5 & 3,5 & 1,4 & 1,4 & 2,1 & 6,4 & 0,7 \\
Total & 3,5 & 3,5 & 1,4 & 0,7 & 2,1 & 2,8 & 0,7 \\
\hline \hline
\end{tabular}

Tabela 74 - Respostas Sobre a Afirmação: "O fato tem o tamanho adequado"

\begin{tabular}{c|ccccccc}
\hline & $\begin{array}{c}\text { Não } \\
\text { aplicável } \\
(\%)\end{array}$ & $\begin{array}{c}\text { Sem } \\
\text { opinião } \\
(\%)\end{array}$ & $\begin{array}{c}\text { Discordo } \\
\text { Totalmente } \\
(\%)\end{array}$ & $\begin{array}{c}\text { Discordo } \\
(\%)\end{array}$ & $\begin{array}{c}\text { Nem } \\
\text { concordo, } \\
\text { nem } \\
\text { Discordo } \\
(\%)\end{array}$ & $\begin{array}{c}\text { Concordo } \\
(\%)\end{array}$ & $\begin{array}{c}\text { Concordo } \\
\text { Totalmente } \\
(\%)\end{array}$ \\
\hline $\begin{array}{c}\text { Cabine de } \\
\text { aplicação de } \\
\text { tintas, vernizes } \\
\text { e tapa poros } \\
\text { Lixagem }\end{array}$ & 5,7 & 5,7 & 2,8 & 1,4 & 3,5 & 11,3 & 9,2 \\
Apoio & 22,0 & 5,7 & 1,4 & 0,7 & 2,1 & 7,1 & 2,1 \\
Outro & 3,5 & 2,8 & 2,1 & 0,7 & 0,7 & 4,3 & 0,7 \\
Total & 2,1 & 0,0 & 0,0 & 0,7 & 0,0 & 0,7 & 0,7 \\
\hline \hline
\end{tabular}


Tabela 75 - Respostas Sobre a Afirmação: "Sei utilizar o fato corretamente"

\begin{tabular}{c|ccccccc}
\hline \hline & $\begin{array}{c}\text { Não } \\
\text { aplicável } \\
(\%)\end{array}$ & $\begin{array}{c}\text { Sem } \\
\text { opinião } \\
(\%)\end{array}$ & $\begin{array}{c}\text { Discordo } \\
\text { Totalmente } \\
(\%)\end{array}$ & $\begin{array}{c}\text { Discordo } \\
(\%)\end{array}$ & $\begin{array}{c}\text { Nem } \\
\text { concordo, } \\
\text { nem } \\
\text { Discordo } \\
(\%)\end{array}$ & $\begin{array}{c}\text { Concordo } \\
(\%)\end{array}$ & $\begin{array}{c}\text { Concordo } \\
\text { Totalmente } \\
(\%)\end{array}$ \\
\hline $\begin{array}{c}\text { Cabine de } \\
\text { aplicação de } \\
\text { tintas, vernizes } \\
\text { e tapa poros } \\
\text { Lixagem }\end{array}$ & 5,7 & 5,7 & 0,7 & 0,0 & 2,8 & 15,6 & 9,2 \\
$\begin{array}{c}\text { Apoio } \\
\text { Outro }\end{array}$ & 2,1 & 6,4 & 0,7 & 0,7 & 2,1 & 7,1 & 2,8 \\
Total & 3,5 & 2,1 & 2,1 & 0,7 & 0,7 & 5,7 & 0,0 \\
\hline \hline
\end{tabular}

Tabela 76 - Respostas Sobre a Afirmação: "Quando o fato está estragado substituo-o imediatamente"

\begin{tabular}{|c|c|c|c|c|c|c|c|}
\hline & $\begin{array}{c}\text { Não } \\
\text { aplicável } \\
(\%)\end{array}$ & $\begin{array}{c}\text { Sem } \\
\text { opinião } \\
(\%)\end{array}$ & $\begin{array}{c}\text { Discordo } \\
\text { Totalmente } \\
\text { (\%) }\end{array}$ & $\begin{array}{c}\text { Discordo } \\
(\%)\end{array}$ & $\begin{array}{c}\text { Nem } \\
\text { concordo, } \\
\text { nem } \\
\text { Discordo } \\
(\%)\end{array}$ & $\begin{array}{c}\text { Concordo } \\
\text { (\%) }\end{array}$ & $\begin{array}{c}\text { Concordo } \\
\text { Totalmente } \\
\text { (\%) }\end{array}$ \\
\hline $\begin{array}{c}\text { Cabine de } \\
\text { aplicação de } \\
\text { tintas, vernizes } \\
\text { e tapa poros }\end{array}$ & 5,7 & 6,4 & 1,4 & 2,1 & 5,7 & 9,9 & 8,5 \\
\hline Lixagem & 22,0 & 7,1 & 0,7 & 0,7 & 2,1 & 6,4 & 2,1 \\
\hline Apoio & 3,5 & 2,1 & 1,4 & 0,7 & 0,7 & 5,7 & 0,7 \\
\hline Outro & 2,1 & 0,0 & 0,0 & 0,7 & 0,0 & 0,7 & 0,7 \\
\hline Total & 33,3 & 15,6 & 3,5 & 4,3 & 8,5 & 22,7 & 12,1 \\
\hline
\end{tabular}


Tabela 77 - Respostas Sobre a Afirmação: "Quando preciso tenho sempre disponível um fato de substituição"

\begin{tabular}{c|ccccccc}
\hline \hline & $\begin{array}{c}\text { Não } \\
\text { aplicável } \\
(\%)\end{array}$ & $\begin{array}{c}\text { Sem } \\
\text { opinião } \\
(\%)\end{array}$ & $\begin{array}{c}\text { Discordo } \\
\text { Totalmente } \\
(\%)\end{array}$ & $\begin{array}{c}\text { Discordo } \\
(\%)\end{array}$ & $\begin{array}{c}\text { Nem } \\
\text { concordo, } \\
\text { nem } \\
\text { Discordo } \\
(\%)\end{array}$ & $\begin{array}{c}\text { Concordo } \\
(\%)\end{array}$ & $\begin{array}{c}\text { Concordo } \\
\text { Totalmente } \\
(\%)\end{array}$ \\
\hline $\begin{array}{c}\text { Cabine de } \\
\text { aplicação de } \\
\text { tintas, vernizes } \\
\text { e tapa poros } \\
\text { Lixagem }\end{array}$ & 5,0 & 6,4 & 1,4 & 4,3 & 4,3 & 8,5 & 9,9 \\
$\begin{array}{c}\text { Apoio } \\
\text { Outro }\end{array}$ & 22,0 & 6,4 & 1,4 & 1,4 & 2,1 & 6,4 & 1,4 \\
Total & 3,5 & 2,8 & 1,4 & 1,4 & 0,0 & 5,0 & 0,7 \\
\hline \hline
\end{tabular}

Tabela 78 - Respostas Sobre a Afirmação: "No verão não uso fato de proteção"

\begin{tabular}{c|ccccccc}
\hline & $\begin{array}{c}\text { Não } \\
\text { aplicável } \\
(\%)\end{array}$ & $\begin{array}{c}\text { Sem } \\
\text { opinião } \\
(\%)\end{array}$ & $\begin{array}{c}\text { Discordo } \\
\text { Totalmente } \\
(\%)\end{array}$ & $\begin{array}{c}\text { Discordo } \\
(\%)\end{array}$ & $\begin{array}{c}\text { Nemcordo, } \\
\text { nem } \\
\text { Discordo } \\
(\%)\end{array}$ & $\begin{array}{c}\text { Concordo } \\
(\%)\end{array}$ & $\begin{array}{c}\text { Concordo } \\
\text { Totalmente } \\
(\%)\end{array}$ \\
\hline $\begin{array}{c}\text { Cabine de } \\
\text { aplicação de } \\
\text { tintas, vernizes } \\
\text { e tapa poros } \\
\text { Lixagem }\end{array}$ & 5,7 & 5,0 & 7,1 & 12,1 & 5,0 & 3,5 & 1,4 \\
Apoio & 22,0 & 5,7 & 4,3 & 3,5 & 2,8 & 2,1 & 0,7 \\
Outro & 3,5 & 3,5 & 2,1 & 2,1 & 1,4 & 2,1 & 0,0 \\
Total & 2,1 & 0,0 & 0,0 & 1,4 & 0,0 & 0,7 & 0,0 \\
\hline \hline
\end{tabular}


Tabela 79 - Respostas Sobre a Afirmação: “Deram-me botas para a manipulação de tintas/velaturas,

vernizes e tapa poros"

\begin{tabular}{c|ccccccc}
\hline \hline & $\begin{array}{c}\text { Não } \\
\text { aplicável } \\
(\%)\end{array}$ & $\begin{array}{c}\text { Sem } \\
\text { opinião } \\
(\%)\end{array}$ & $\begin{array}{c}\text { Discordo } \\
\text { Totalmente } \\
(\%)\end{array}$ & $\begin{array}{c}\text { Discordo } \\
(\%)\end{array}$ & $\begin{array}{c}\text { Nem } \\
\text { concordo, } \\
\text { nem } \\
\text { Discordo } \\
(\%)\end{array}$ & $\begin{array}{c}\text { Concordo } \\
(\%)\end{array}$ & $\begin{array}{c}\text { Concordo } \\
\text { Totalmente } \\
(\%)\end{array}$ \\
\hline $\begin{array}{c}\text { Cabine de } \\
\text { aplicação de } \\
\text { tintas, vernizes } \\
\text { e tapa poros } \\
\text { Lixagem }\end{array}$ & 10,0 & 1,4 & 4,3 & 5,0 & 1,4 & 10,7 & 7,1 \\
Apoio & 25,0 & 3,6 & 2,1 & 2,9 & 0,7 & 5,0 & 1,4 \\
Outro & 5,0 & 1,4 & 1,4 & 0,7 & 0,7 & 5,0 & 0,7 \\
Total & 2,1 & 0,0 & 0,0 & 0,7 & 0,0 & 1,4 & 0,0 \\
\hline \hline
\end{tabular}

Tabela 80 - Respostas Sobre a Afirmação: "Penso que as botas que deram para a manipulação de tintas/velaturas, vernizes e tapa poros são as mais adequadas"

\begin{tabular}{c|ccccccc}
\hline & $\begin{array}{c}\text { Não } \\
\text { aplicável } \\
(\%)\end{array}$ & $\begin{array}{c}\text { Sem } \\
\text { opinião } \\
(\%)\end{array}$ & $\begin{array}{c}\text { Discordo } \\
\text { Totalmente } \\
(\%)\end{array}$ & $\begin{array}{c}\text { Discordo } \\
(\%)\end{array}$ & $\begin{array}{c}\text { Nem } \\
\text { concordo, } \\
\text { nem } \\
\text { Discordo } \\
(\%)\end{array}$ & $\begin{array}{c}\text { Concordo } \\
(\%)\end{array}$ & $\begin{array}{c}\text { Concordo } \\
\text { Totalmente } \\
(\%)\end{array}$ \\
\hline $\begin{array}{c}\text { Cabine de } \\
\text { aplicação de } \\
\text { tintas, vernizes } \\
\text { e tapa poros } \\
\text { Lixagem }\end{array}$ & 12,1 & 3,6 & 2,9 & 2,9 & 1,4 & 10,7 & 6,4 \\
Apoio & 24,3 & 5,7 & 1,4 & 2,1 & 2,1 & 3,6 & 1,4 \\
Outro & 5,0 & 1,4 & 1,4 & 0,7 & 0,7 & 5,0 & 0,7 \\
Total & 2,1 & 0,0 & 0,0 & 0,7 & 0,0 & 1,4 & 0,0 \\
\hline \hline
\end{tabular}


Tabela 81 - Respostas Sobre a Afirmação: "As botas têm o tamanho adequado"

\begin{tabular}{|c|c|c|c|c|c|c|c|}
\hline & $\begin{array}{c}\text { Não } \\
\text { aplicável } \\
(\%)\end{array}$ & $\begin{array}{c}\text { Sem } \\
\text { opinião } \\
(\%)\end{array}$ & $\begin{array}{c}\text { Discordo } \\
\text { Totalmente } \\
\text { (\%) }\end{array}$ & $\begin{array}{c}\text { Discordo } \\
(\%)\end{array}$ & $\begin{array}{c}\text { Nem } \\
\text { concordo, } \\
\text { nem } \\
\text { Discordo } \\
(\%)\end{array}$ & $\begin{array}{c}\text { Concordo } \\
\text { (\%) }\end{array}$ & $\begin{array}{c}\text { Concordo } \\
\text { Totalmente } \\
\text { (\%) }\end{array}$ \\
\hline $\begin{array}{c}\text { Cabine de } \\
\text { aplicação de } \\
\text { tintas, vernizes } \\
\text { e tapa poros }\end{array}$ & 12,2 & 3,6 & 2,9 & 1,4 & 1,4 & 12,9 & 5,8 \\
\hline Lixagem & 23,7 & 2,9 & 0,7 & 2,2 & 2,2 & 4,3 & 4,3 \\
\hline Apoio & 5,0 & 1,4 & 1,4 & 0,7 & 0,7 & 5,0 & 0,7 \\
\hline Outro & 2,2 & 0,0 & 0,0 & 0,7 & 0,0 & 0,7 & 0,7 \\
\hline Total & 43,2 & 7,9 & 5,0 & 5,0 & 4,3 & 23,0 & 11,5 \\
\hline
\end{tabular}

Tabela 82 - Respostas Sobre a Afirmação: "Quando as botas estão estragadas substituo-as imediatamente"

\begin{tabular}{c|ccccccc}
\hline \hline & $\begin{array}{c}\text { Não } \\
\text { aplicável } \\
(\%)\end{array}$ & $\begin{array}{c}\text { Sem } \\
\text { opinião } \\
(\%)\end{array}$ & $\begin{array}{c}\text { Discordo } \\
\text { Totalmente } \\
(\%)\end{array}$ & $\begin{array}{c}\text { Discordo } \\
(\%)\end{array}$ & $\begin{array}{c}\text { Nem } \\
\text { concordo, } \\
\text { nem } \\
\text { Discordo } \\
(\%)\end{array}$ & $\begin{array}{c}\text { Concordo } \\
(\%)\end{array}$ & $\begin{array}{c}\text { Concordo } \\
\text { Totalmente } \\
(\%)\end{array}$ \\
\hline $\begin{array}{c}\text { Cabine de } \\
\text { aplicação de } \\
\text { tintas, vernizes } \\
\text { e tapa poros } \\
\text { Lixagem }\end{array}$ & 11,4 & 5,7 & 2,9 & 2,9 & 2,9 & 7,9 & 6,4 \\
$\begin{array}{c}\text { Apoio } \\
\text { Outro }\end{array}$ & 24,3 & 2,9 & 0,7 & 2,1 & 2,1 & 5,7 & 2,9 \\
Total & 5,0 & 2,1 & 1,4 & 1,4 & 0,0 & 4,3 & 0,7 \\
\hline \hline
\end{tabular}


Tabela 83 - Respostas Sobre a Afirmação: "Quando preciso tenho sempre disponível umas botas de substituição"

\begin{tabular}{c|ccccccc}
\hline \hline & $\begin{array}{c}\text { Não } \\
\text { aplicável } \\
(\%)\end{array}$ & $\begin{array}{c}\text { Sem } \\
\text { opinião } \\
(\%)\end{array}$ & $\begin{array}{c}\text { Discordo } \\
\text { Totalmente } \\
(\%)\end{array}$ & $\begin{array}{c}\text { Discordo } \\
(\%)\end{array}$ & $\begin{array}{c}\text { Nem } \\
\text { concordo, } \\
\text { nem } \\
\text { Discordo } \\
(\%)\end{array}$ & $\begin{array}{c}\text { Concordo } \\
(\%)\end{array}$ & $\begin{array}{c}\text { Concordo } \\
\text { Totalmente } \\
(\%)\end{array}$ \\
\hline $\begin{array}{c}\text { Cabine de } \\
\text { aplicação de } \\
\text { tintas, vernizes } \\
\text { e tapa poros } \\
\text { Lixagem }\end{array}$ & 12,1 & 5,0 & 2,9 & 4,3 & 2,1 & 7,9 & 5,7 \\
$\begin{array}{c}\text { Apoio } \\
\text { Outro }\end{array}$ & 23,6 & 3,6 & 0,7 & 2,9 & 2,1 & 4,3 & 3,6 \\
Total & 5,0 & 2,1 & 1,4 & 0,7 & 1,4 & 3,6 & 0,7 \\
\hline \hline
\end{tabular}

Tabela 84 - Respostas Sobre a Afirmação: "Uso sempre botas"

\begin{tabular}{c|ccccccc}
\hline & $\begin{array}{c}\text { Não } \\
\text { aplicável } \\
(\%)\end{array}$ & $\begin{array}{c}\text { Sem } \\
\text { opinião } \\
(\%)\end{array}$ & $\begin{array}{c}\text { Discordo } \\
\text { Totalmente } \\
(\%)\end{array}$ & $\begin{array}{c}\text { Discordo } \\
(\%)\end{array}$ & $\begin{array}{c}\text { Nem } \\
\text { concordo, } \\
\text { nem } \\
\text { Discordo } \\
(\%)\end{array}$ & $\begin{array}{c}\text { Concordo } \\
(\%)\end{array}$ & $\begin{array}{c}\text { Concordo } \\
\text { Totalmente } \\
(\%)\end{array}$ \\
\hline $\begin{array}{c}\text { Cabine de } \\
\text { aplicação de } \\
\text { tintas, vernizes } \\
\text { e tapa poros } \\
\text { Lixagem }\end{array}$ & 12,9 & 3,6 & 2,9 & 2,9 & 2,1 & 8,6 & 7,1 \\
Apoio & 23,6 & 2,9 & 0,0 & 1,4 & 1,4 & 5,7 & 5,7 \\
Outro & 5,0 & 2,1 & 1,4 & 0,7 & 1,4 & 4,3 & 0,0 \\
Total & 2,1 & 0,0 & 0,0 & 0,7 & 0,0 & 0,7 & 0,7 \\
\hline \hline
\end{tabular}




\subsection{Utilização de Equipamentos de Proteção Coletiva}

Tabela 85 - Respostas Sobre a Afirmação: "Não é necessário o funcionamento das cabines desde que utilize a máscara de proteção respiratória para gases"

\begin{tabular}{c|ccccccc}
\hline \hline & $\begin{array}{c}\text { Não } \\
\text { aplicável } \\
(\%)\end{array}$ & $\begin{array}{c}\text { Sem } \\
\text { opinião } \\
(\%)\end{array}$ & $\begin{array}{c}\text { Discordo } \\
\text { Totalmente } \\
(\%)\end{array}$ & $\begin{array}{c}\text { Discordo } \\
(\%)\end{array}$ & $\begin{array}{c}\text { Noncordo, } \\
\text { nem } \\
\text { Discordo } \\
(\%)\end{array}$ & $\begin{array}{c}\text { Concordo } \\
(\%)\end{array}$ & $\begin{array}{c}\text { Concordo } \\
\text { Totalmente } \\
(\%)\end{array}$ \\
\hline $\begin{array}{c}\text { Cabine de } \\
\text { aplicação de } \\
\text { tintas, vernizes } \\
\text { e tapa poros } \\
\text { Lixagem }\end{array}$ & 0,0 & 0,0 & 19,3 & 20,0 & 0,0 & 0,7 & 0,0 \\
Apoio & 12,1 & 2,1 & 10,7 & 12,1 & 0,7 & 2,9 & 0,0 \\
Outro & 0,0 & 0,7 & 2,9 & 8,6 & 0,7 & 2,1 & 0,0 \\
Total & 0,0 & 0,0 & 0,7 & 2,9 & 0,0 & 0,0 & 0,7 \\
\hline \hline
\end{tabular}

Tabela 86 - Respostas Sobre a Afirmação: "Ligo sempre as cabines quando aplico as tintas/velaturas, vernizes e tapa poros"

\begin{tabular}{|c|c|c|c|c|c|c|c|}
\hline & $\begin{array}{c}\text { Não } \\
\text { aplicável } \\
(\%)\end{array}$ & $\begin{array}{c}\text { Sem } \\
\text { opinião } \\
(\%)\end{array}$ & $\begin{array}{c}\text { Discordo } \\
\text { Totalmente } \\
\text { (\%) }\end{array}$ & $\begin{array}{c}\text { Discordo } \\
(\%)\end{array}$ & $\begin{array}{c}\text { Nem } \\
\text { concordo, } \\
\text { nem } \\
\text { Discordo } \\
(\%)\end{array}$ & $\begin{array}{c}\text { Concordo } \\
\text { (\%) }\end{array}$ & $\begin{array}{c}\text { Concordo } \\
\text { Totalmente } \\
\text { (\%) }\end{array}$ \\
\hline $\begin{array}{c}\text { Cabine de } \\
\text { aplicação de } \\
\text { tintas, vernizes } \\
\text { e tapa poros }\end{array}$ & 2,1 & 0,0 & 0,0 & 0,0 & 0,0 & 22,1 & 15,7 \\
\hline Lixagem & 20,7 & 2,1 & 0,0 & 0,0 & 0,0 & 9,3 & 7,9 \\
\hline Apoio & 1,4 & 0,7 & 0,0 & 0,0 & 0,0 & 10,7 & 2,1 \\
\hline Outro & 1,4 & 0,0 & 0,0 & 0,0 & 0,0 & 1,4 & 1,4 \\
\hline Total & 25,7 & 2,8 & 0,0 & 0,0 & 0,0 & 43,6 & 27,1 \\
\hline
\end{tabular}


Tabela 87 - Respostas Sobre a Afirmação: "Não é necessário o funcionamento dos equipamentos de extração desde que utilize a máscara de proteção respiratória para gases"

\begin{tabular}{|c|c|c|c|c|c|c|c|}
\hline & $\begin{array}{c}\text { Não } \\
\text { aplicável } \\
(\%)\end{array}$ & $\begin{array}{c}\text { Sem } \\
\text { opinião } \\
(\%)\end{array}$ & $\begin{array}{c}\text { Discordo } \\
\text { Totalmente } \\
\text { (\%) }\end{array}$ & $\begin{array}{c}\text { Discordo } \\
(\%)\end{array}$ & $\begin{array}{c}\text { Nem } \\
\text { concordo, } \\
\text { nem } \\
\text { Discordo } \\
(\%)\end{array}$ & $\begin{array}{c}\text { Concordo } \\
\text { (\%) }\end{array}$ & $\begin{array}{c}\text { Concordo } \\
\text { Totalmente } \\
\text { (\%) }\end{array}$ \\
\hline $\begin{array}{c}\text { Cabine de } \\
\text { aplicação de } \\
\text { tintas, vernizes } \\
\text { e tapa poros }\end{array}$ & 0,0 & 0,0 & 17,9 & 20,7 & 1,4 & 0,0 & 0,0 \\
\hline Lixagem & 9,3 & 2,1 & 12,1 & 10,7 & 0,7 & 2,9 & 2,9 \\
\hline Apoio & 0,0 & 0,7 & 5,0 & 7,9 & 0,0 & 0,0 & 1,4 \\
\hline Outro & 0,0 & 0,0 & 2,1 & 2,1 & 0,0 & 0,0 & 0,0 \\
\hline Total & 9,3 & 2,9 & 37,1 & 41,2 & 2,1 & 2,9 & 4,3 \\
\hline
\end{tabular}

Tabela 88 - Respostas Sobre a Afirmação: "No inverno às vezes não ligo as cabines"

\begin{tabular}{c|ccccccc}
\hline \hline & $\begin{array}{c}\text { Não } \\
\text { aplicável } \\
(\%)\end{array}$ & $\begin{array}{c}\text { Sem } \\
\text { opinião } \\
(\%)\end{array}$ & $\begin{array}{c}\text { Discordo } \\
\text { Totalmente } \\
(\%)\end{array}$ & $\begin{array}{c}\text { Discordo } \\
(\%)\end{array}$ & $\begin{array}{c}\text { Nem } \\
\text { concordo, } \\
\text { nem } \\
\text { Discordo } \\
(\%)\end{array}$ & $\begin{array}{c}\text { Concordo } \\
(\%)\end{array}$ & $\begin{array}{c}\text { Concordo } \\
\text { Totalmente } \\
(\%)\end{array}$ \\
\hline $\begin{array}{c}\text { Cabine de } \\
\text { aplicação de } \\
\text { tintas, vernizes } \\
\text { e tapa poros } \\
\text { Lixagem }\end{array}$ & 1,4 & 0,0 & 18,6 & 17,9 & 0,0 & 1,4 & 0,7 \\
Apoio & 15,7 & 1,4 & 12,1 & 9,3 & 1,4 & 0,7 & 0,0 \\
Outro & 0,7 & 0,7 & 3,6 & 7,9 & 0,0 & 1,4 & 0,7 \\
Total & 0,7 & 0,7 & 1,4 & 1,4 & 0,0 & 0,0 & 0,0 \\
\hline \hline
\end{tabular}


Tabela 89 - Respostas Sobre a Afirmação: "Quando está frio não ligo os equipamentos de extração"

\begin{tabular}{c|ccccccc}
\hline \hline & $\begin{array}{c}\text { Não } \\
\text { aplicável } \\
(\%)\end{array}$ & $\begin{array}{c}\text { Sem } \\
\text { opinião } \\
(\%)\end{array}$ & $\begin{array}{c}\text { Discordo } \\
\text { Totalmente } \\
(\%)\end{array}$ & $\begin{array}{c}\text { Discordo } \\
(\%)\end{array}$ & $\begin{array}{c}\text { Nem } \\
\text { concordo, } \\
\text { nem } \\
\text { Discordo } \\
(\%)\end{array}$ & $\begin{array}{c}\text { Concordo } \\
(\%)\end{array}$ & $\begin{array}{c}\text { Concordo } \\
\text { Totalmente } \\
(\%)\end{array}$ \\
\hline $\begin{array}{c}\text { Cabine de } \\
\text { aplicação de } \\
\text { tintas, vernizes } \\
\text { e tapa poros } \\
\text { Lixagem }\end{array}$ & 1,4 & 0,0 & 17,3 & 20,1 & 0,0 & 0,0 & 0,7 \\
Apoio & 12,9 & 1,4 & 14,4 & 11,5 & 0,0 & 0,7 & 0,0 \\
Outro & 0,7 & 1,4 & 2,9 & 10,1 & 0,0 & 0,0 & 0,0 \\
Total & 0,7 & 0,7 & 1,4 & 1,4 & 0,0 & 0,0 & 0,0 \\
\hline \hline
\end{tabular}




\subsection{Efeitos Fisiológicos Subsequentes à Exposição a Tintas/Velaturas, Vernizes e Tapa Poros}

Tabela 90 - Respostas Sobre a Afirmação: "A exposição às tintas/velaturas, vernizes e tapa poros provoca-me irritação no nariz e garganta"

\begin{tabular}{|c|c|c|c|c|c|c|c|}
\hline & $\begin{array}{c}\text { Não } \\
\text { aplicável } \\
(\%)\end{array}$ & $\begin{array}{l}\text { Sem } \\
\text { opinião } \\
(\%)\end{array}$ & $\begin{array}{c}\text { Discordo } \\
\text { Totalmente } \\
\text { (\%) }\end{array}$ & $\begin{array}{c}\text { Discordo } \\
(\%)\end{array}$ & $\begin{array}{c}\text { Nem } \\
\text { concordo, } \\
\text { nem } \\
\text { Discordo } \\
(\%)\end{array}$ & $\begin{array}{c}\text { Concordo } \\
\text { (\%) }\end{array}$ & $\begin{array}{c}\text { Concordo } \\
\text { Totalmente } \\
\text { (\%) }\end{array}$ \\
\hline $\begin{array}{c}\text { Cabine de } \\
\text { aplicação de } \\
\text { tintas, vernizes } \\
\text { e tapa poros }\end{array}$ & 0,0 & 0,7 & 0,7 & 13,5 & 5,0 & 15,6 & 4,3 \\
\hline Lixagem & 9,9 & 2,1 & 0,0 & 6,4 & 4,3 & 11,3 & 7,1 \\
\hline Apoio & 0,7 & 1,4 & 0,0 & 6,4 & 1,4 & 2,8 & 2,1 \\
\hline Outro & 0,7 & 0,0 & 0,7 & 1,4 & 0,0 & 1,4 & 0,0 \\
\hline Total & 11,3 & 4,3 & 1,4 & 27,7 & 10,6 & 31,2 & 13,5 \\
\hline
\end{tabular}


Tabela 91 - Respostas Sobre a Afirmação: “A exposição às tintas/velaturas, vernizes e tapa poros provoca-me irritação dos olhos"

\begin{tabular}{c|ccccccc}
\hline \hline & $\begin{array}{c}\text { Não } \\
\text { aplicável } \\
(\%)\end{array}$ & $\begin{array}{c}\text { Sem } \\
\text { opinião } \\
(\%)\end{array}$ & $\begin{array}{c}\text { Discordo } \\
\text { Totalmente } \\
(\%)\end{array}$ & $\begin{array}{c}\text { Discordo } \\
(\%)\end{array}$ & $\begin{array}{c}\text { Nem } \\
\text { concordo, } \\
\text { nem } \\
\text { Discordo } \\
(\%)\end{array}$ & $\begin{array}{c}\text { Concordo } \\
(\%)\end{array}$ & $\begin{array}{c}\text { Concordo } \\
\text { Totalmente } \\
(\%)\end{array}$ \\
\hline $\begin{array}{c}\text { Cabine de } \\
\text { aplicação de } \\
\text { tintas, vernizes } \\
\text { e tapa poros } \\
\text { Lixagem }\end{array}$ & 0,0 & 0,0 & 0,7 & 15,7 & 7,1 & 12,1 & 3,6 \\
$\begin{array}{c}\text { Apoio } \\
\text { Outro }\end{array}$ & 10,0 & 2,9 & 0,7 & 9,3 & 5,0 & 8,6 & 5,0 \\
Total & 1,4 & 1,4 & 0,0 & 4,3 & 2,9 & 2,9 & 2,1 \\
\hline \hline
\end{tabular}

Tabela 92 - Respostas Sobre a Afirmação: "Durante o trabalho com as tintas/velaturas, vernizes e tapa poros já tive irritação nos olhos"

\begin{tabular}{c|ccccccc}
\hline & $\begin{array}{c}\text { Não } \\
\text { aplicável } \\
(\%)\end{array}$ & $\begin{array}{c}\text { Sem } \\
\text { opinião } \\
(\%)\end{array}$ & $\begin{array}{c}\text { Discordo } \\
\text { Totalmente } \\
(\%)\end{array}$ & $\begin{array}{c}\text { Discordo } \\
(\%)\end{array}$ & $\begin{array}{c}\text { Nem } \\
\text { concordo, } \\
\text { nem } \\
\text { Discordo } \\
(\%)\end{array}$ & $\begin{array}{c}\text { Concordo } \\
(\%)\end{array}$ & $\begin{array}{c}\text { Concordo } \\
\text { Totalmente } \\
(\%)\end{array}$ \\
\hline $\begin{array}{c}\text { Cabine de } \\
\text { aplicação de } \\
\text { tintas, vernizes } \\
\text { e tapa poros } \\
\text { Lixagem }\end{array}$ & 0,0 & 0,7 & 1,4 & 15,6 & 4,3 & 13,5 & 4,3 \\
Apoio & 13,5 & 5,7 & 0,0 & 7,1 & 2,8 & 8,5 & 3,5 \\
Outro & 1,4 & 2,1 & 0,7 & 3,5 & 1,4 & 3,5 & 2,1 \\
Total & 0,7 & 0,0 & 0,0 & 2,1 & 0,7 & 0,0 & 0,7 \\
\hline \hline
\end{tabular}


Tabela 93 - Respostas Sobre a Afirmação: "Durante o trabalho com as tintas/velaturas, vernizes e tapa poros já tive irritação no nariz e garganta"

\begin{tabular}{c|ccccccc}
\hline & $\begin{array}{c}\text { Não } \\
\text { aplicável } \\
(\%)\end{array}$ & $\begin{array}{c}\text { Sem } \\
\text { opinião } \\
(\%)\end{array}$ & $\begin{array}{c}\text { Discordo } \\
\text { Totalmente } \\
(\%)\end{array}$ & $\begin{array}{c}\text { Discordo } \\
(\%)\end{array}$ & $\begin{array}{c}\text { Nemcordo, } \\
\text { nem } \\
\text { Discordo } \\
(\%)\end{array}$ & $\begin{array}{c}\text { Concordo } \\
(\%)\end{array}$ & $\begin{array}{c}\text { Concordo } \\
\text { Totalmente } \\
(\%)\end{array}$ \\
\hline $\begin{array}{c}\text { Cabine de } \\
\text { aplicação de } \\
\text { tintas, vernizes } \\
\text { e tapa poros } \\
\text { Lixagem }\end{array}$ & 0,0 & 0,7 & 1,4 & 12,9 & 2,1 & 19,3 & 3,6 \\
Apoio & 13,6 & 1,4 & 0,7 & 6,4 & 2,1 & 12,1 & 5,0 \\
Outro & 1,4 & 2,1 & 0,7 & 6,4 & 0,0 & 2,9 & 1,4 \\
Total & 0,7 & 0,0 & 0,0 & 2,1 & 0,0 & 0,7 & 0,0 \\
\hline \hline
\end{tabular}

Tabela 94 - Respostas Sobre a Afirmação: “A exposição às tintas/velaturas, vernizes e tapa poros provoca-me dores de cabeça"

\begin{tabular}{c|ccccccc}
\hline & $\begin{array}{c}\text { Não } \\
\text { aplicável } \\
(\%)\end{array}$ & $\begin{array}{c}\text { Sem } \\
\text { opinião } \\
(\%)\end{array}$ & $\begin{array}{c}\text { Discordo } \\
\text { Totalmente } \\
(\%)\end{array}$ & $\begin{array}{c}\text { Discordo } \\
(\%)\end{array}$ & $\begin{array}{c}\text { Nem } \\
\text { concordo, } \\
\text { nem } \\
\text { Discordo } \\
(\%)\end{array}$ & $\begin{array}{c}\text { Concordo } \\
(\%)\end{array}$ & $\begin{array}{c}\text { Concordo } \\
\text { Totalmente } \\
(\%)\end{array}$ \\
\hline $\begin{array}{c}\text { Cabine de } \\
\text { aplicação de } \\
\text { tintas, vernizes } \\
\text { e tapa poros } \\
\text { Lixagem }\end{array}$ & 0,0 & 1,4 & 0,7 & 18,7 & 8,6 & 10,1 & 0,7 \\
Apoio & 8,6 & 6,5 & 2,2 & 5,0 & 7,9 & 7,2 & 2,9 \\
Outro & 0,7 & 4,3 & 0,7 & 4,3 & 1,4 & 2,9 & 0,7 \\
Total & 0,0 & 0,0 & 0,7 & 2,2 & 0,0 & 1,4 & 0,0 \\
\hline \hline
\end{tabular}


Tabela 95 - Respostas Sobre a Afirmação: "Tenho frequentemente dores de cabeça"

\begin{tabular}{c|ccccccc}
\hline \hline & $\begin{array}{c}\text { Não } \\
\text { aplicável } \\
(\%)\end{array}$ & $\begin{array}{c}\text { Sem } \\
\text { opinião } \\
(\%)\end{array}$ & $\begin{array}{c}\text { Discordo } \\
\text { Totalmente } \\
(\%)\end{array}$ & $\begin{array}{c}\text { Discordo } \\
(\%)\end{array}$ & $\begin{array}{c}\text { Nem } \\
\text { concordo, } \\
\text { nem } \\
\text { Discordo } \\
(\%)\end{array}$ & $\begin{array}{c}\text { Concordo } \\
(\%)\end{array}$ & $\begin{array}{c}\text { Concordo } \\
\text { Totalmente } \\
(\%)\end{array}$ \\
\hline $\begin{array}{c}\text { Cabine de } \\
\text { aplicação de } \\
\text { tintas, vernizes } \\
\text { e tapa poros } \\
\text { Lixagem }\end{array}$ & 0,7 & 3,6 & 0,7 & 21,4 & 5,7 & 7,1 & 0,7 \\
Apoio & 7,1 & 7,1 & 2,9 & 14,3 & 5,7 & 2,1 & 1,4 \\
Outro & 0,7 & 1,4 & 1,4 & 6,4 & 2,1 & 2,1 & 0,7 \\
Total & 0,0 & 0,0 & 0,7 & 1,4 & 0,7 & 0,7 & 0,7 \\
\hline \hline
\end{tabular}

Tabela 96 - Respostas Sobre a Afirmação: "Antes de trabalhar na empresa de mobiliário não tinha dores de cabeça"

\begin{tabular}{c|ccccccc}
\hline & $\begin{array}{c}\text { Não } \\
\text { aplicável } \\
(\%)\end{array}$ & $\begin{array}{c}\text { Sem } \\
\text { opinião } \\
(\%)\end{array}$ & $\begin{array}{c}\text { Discordo } \\
\text { Totalmente } \\
(\%)\end{array}$ & $\begin{array}{c}\text { Discordo } \\
(\%)\end{array}$ & $\begin{array}{c}\text { Nem } \\
\text { concordo, } \\
\text { nem } \\
\text { Discordo } \\
(\%)\end{array}$ & $\begin{array}{c}\text { Concordo } \\
(\%)\end{array}$ & $\begin{array}{c}\text { Concordo } \\
\text { Totalmente } \\
(\%)\end{array}$ \\
\hline $\begin{array}{c}\text { Cabine de } \\
\text { aplicação de } \\
\text { tintas, vernizes } \\
\text { e tapa poros } \\
\text { Lixagem }\end{array}$ & 2,9 & 5,1 & 2,2 & 19,6 & 5,1 & 3,6 & 2,2 \\
Apoio & 8,0 & 6,5 & 0,7 & 10,9 & 6,5 & 5,8 & 2,2 \\
Outro & 1,4 & 3,6 & 0,0 & 5,1 & 1,4 & 2,2 & 0,7 \\
Total & 0,0 & 0,7 & 1,4 & 1,4 & 0,7 & 0,0 & 0,0 \\
\hline \hline
\end{tabular}


Tabela 97 - Respostas Sobre a Afirmação: "Antes de trabalhar na empresa de mobiliário tinha menos dores de cabeça"

\begin{tabular}{c|ccccccc}
\hline \hline & $\begin{array}{c}\text { Não } \\
\text { aplicável } \\
(\%)\end{array}$ & $\begin{array}{c}\text { Sem } \\
\text { opinião } \\
(\%)\end{array}$ & $\begin{array}{c}\text { Discordo } \\
\text { Totalmente } \\
(\%)\end{array}$ & $\begin{array}{c}\text { Discordo } \\
(\%)\end{array}$ & $\begin{array}{c}\text { Nem } \\
\text { concordo, } \\
\text { nem } \\
\text { Discordo } \\
(\%)\end{array}$ & $\begin{array}{c}\text { Concordo } \\
(\%)\end{array}$ & $\begin{array}{c}\text { Concordo } \\
\text { Totalmente } \\
(\%)\end{array}$ \\
\hline $\begin{array}{c}\text { Cabine de } \\
\text { aplicação de } \\
\text { tintas, vernizes } \\
\text { e tapa poros } \\
\text { Lixagem }\end{array}$ & 2,9 & 5,9 & 3,7 & 16,2 & 4,4 & 5,9 & 2,2 \\
Apoio & 7,4 & 5,9 & 2,9 & 12,5 & 6,6 & 3,7 & 0,7 \\
Outro & 1,5 & 3,7 & 1,5 & 6,6 & 0,7 & 0,7 & 0,0 \\
Total & 0,0 & 0,7 & 1,5 & 1,5 & 0,7 & 0,0 & 0,0 \\
\hline \hline
\end{tabular}

Tabela 98 - Respostas Sobre a Afirmação: "A exposição às tintas/velaturas, vernizes e tapa poros causame sonolência"

\begin{tabular}{c|ccccccc}
\hline & $\begin{array}{c}\text { Não } \\
\text { aplicável } \\
(\%)\end{array}$ & $\begin{array}{c}\text { Sem } \\
\text { opinião } \\
(\%)\end{array}$ & $\begin{array}{c}\text { Discordo } \\
\text { Totalmente } \\
(\%)\end{array}$ & $\begin{array}{c}\text { Discordo } \\
(\%)\end{array}$ & $\begin{array}{c}\text { Nem } \\
\text { concordo, } \\
\text { nem } \\
\text { Discordo } \\
(\%)\end{array}$ & $\begin{array}{c}\text { Concordo } \\
(\%)\end{array}$ & $\begin{array}{c}\text { Concordo } \\
\text { Totalmente } \\
(\%)\end{array}$ \\
\hline $\begin{array}{c}\text { Cabine de } \\
\text { aplicação de } \\
\text { tintas, vernizes } \\
\text { e tapa poros } \\
\text { Lixagem }\end{array}$ & 0,0 & 5,8 & 2,2 & 20,9 & 6,5 & 5,0 & 0,0 \\
Apoio & 10,1 & 8,6 & 2,9 & 12,9 & 4,3 & 2,2 & 0,0 \\
Outro & 2,2 & 1,4 & 2,2 & 5,0 & 1,4 & 1,4 & 0,7 \\
Total & 0,0 & 0,7 & 1,4 & 1,4 & 0,7 & 0,0 & 0,0 \\
\hline \hline
\end{tabular}


Tabela 99 - Respostas Sobre a Afirmação: "Quando estou exposto às tintas/velaturas, vernizes e tapa poros perco o apetite"

\begin{tabular}{c|ccccccc}
\hline \hline & $\begin{array}{c}\text { Não } \\
\text { aplicável } \\
(\%)\end{array}$ & $\begin{array}{c}\text { Sem } \\
\text { opinião } \\
(\%)\end{array}$ & $\begin{array}{c}\text { Discordo } \\
\text { Totalmente } \\
(\%)\end{array}$ & $\begin{array}{c}\text { Discordo } \\
(\%)\end{array}$ & $\begin{array}{c}\text { Nem } \\
\text { concordo, } \\
\text { nem } \\
\text { Discordo } \\
(\%)\end{array}$ & $\begin{array}{c}\text { Concordo } \\
(\%)\end{array}$ & $\begin{array}{c}\text { Concordo } \\
\text { Totalmente } \\
(\%)\end{array}$ \\
\hline $\begin{array}{c}\text { Cabine de } \\
\text { aplicação de } \\
\text { tintas, vernizes } \\
\text { e tapa poros } \\
\text { Lixagem }\end{array}$ & 0,7 & 5,0 & 2,2 & 23,7 & 5,0 & 3,6 & 0,0 \\
Apoio & 10,8 & 7,2 & 4,3 & 12,2 & 0,7 & 4,3 & 0,7 \\
Outro & 2,2 & 1,4 & 0,7 & 7,9 & 1,4 & 0,0 & 1,4 \\
Total & 0,0 & 0,0 & 1,4 & 2,2 & 0,7 & 0,0 & 0,0 \\
\hline \hline
\end{tabular}

Tabela 100 - Respostas Sobre a Afirmação: "Desde que trabalho com as tintas/velaturas, vernizes e tapa poros tenho maior dificuldade em ouvir"

\begin{tabular}{c|ccccccc}
\hline & $\begin{array}{c}\text { Não } \\
\text { aplicável } \\
(\%)\end{array}$ & $\begin{array}{c}\text { Sem } \\
\text { opinião } \\
(\%)\end{array}$ & $\begin{array}{c}\text { Discordo } \\
\text { Totalmente } \\
(\%)\end{array}$ & $\begin{array}{c}\text { Discordo } \\
(\%)\end{array}$ & $\begin{array}{c}\text { Nem } \\
\text { concordo, } \\
\text { nem } \\
\text { Discordo } \\
(\%)\end{array}$ & $\begin{array}{c}\text { Concordo } \\
(\%)\end{array}$ & $\begin{array}{c}\text { Concordo } \\
\text { Totalmente } \\
(\%)\end{array}$ \\
\hline $\begin{array}{c}\text { Cabine de } \\
\text { aplicação de } \\
\text { tintas, vernizes } \\
\text { e tapa poros } \\
\text { Lixagem }\end{array}$ & 0,0 & 5,0 & 2,9 & 23,7 & 4,3 & 3,6 & 0,0 \\
Apoio & 9,4 & 5,8 & 4,3 & 12,9 & 3,6 & 4,3 & 1,4 \\
Outro & 1,4 & 1,4 & 0,0 & 5,8 & 2,9 & 2,2 & 0,7 \\
Total & 0,0 & 0,0 & 1,4 & 2,2 & 0,7 & 0,0 & 0,0 \\
\hline \hline
\end{tabular}


Tabela 101 - Respostas Sobre a Afirmação: "Há muito ruído no meu posto de trabalho"

\begin{tabular}{c|ccccccc}
\hline \hline & $\begin{array}{c}\text { Não } \\
\text { aplicável } \\
(\%)\end{array}$ & $\begin{array}{c}\text { Sem } \\
\text { opinião } \\
(\%)\end{array}$ & $\begin{array}{c}\text { Discordo } \\
\text { Totalmente } \\
(\%)\end{array}$ & $\begin{array}{c}\text { Discordo } \\
(\%)\end{array}$ & $\begin{array}{c}\text { Nem } \\
\text { concordo, } \\
\text { nem } \\
\text { Discordo } \\
(\%)\end{array}$ & $\begin{array}{c}\text { Concordo } \\
(\%)\end{array}$ & $\begin{array}{c}\text { Concordo } \\
\text { Totalmente } \\
(\%)\end{array}$ \\
\hline $\begin{array}{c}\text { Cabine de } \\
\text { aplicação de } \\
\text { tintas, vernizes } \\
\text { e tapa poros } \\
\text { Lixagem }\end{array}$ & 0,0 & 0,0 & 0,0 & 11,8 & 8,8 & 16,9 & 2,9 \\
Apoio & 2,2 & 2,2 & 1,5 & 7,4 & 7,4 & 14,0 & 6,6 \\
Outro & 0,0 & 1,5 & 0,0 & 2,9 & 2,9 & 5,1 & 1,5 \\
Total & 0,0 & 0,0 & 0,0 & 0,7 & 1,5 & 2,2 & 0,0 \\
\hline \hline
\end{tabular}

Tabela 102 - Respostas Sobre a Afirmação: "Por vezes tenho vómitos no trabalho"

\begin{tabular}{c|ccccccc}
\hline \hline & $\begin{array}{c}\text { Não } \\
\text { aplicável } \\
(\%)\end{array}$ & $\begin{array}{c}\text { Sem } \\
\text { opinião } \\
(\%)\end{array}$ & $\begin{array}{c}\text { Discordo } \\
\text { Totalmente } \\
(\%)\end{array}$ & $\begin{array}{c}\text { Discordo } \\
(\%)\end{array}$ & $\begin{array}{c}\text { Nem } \\
\text { concordo, } \\
\text { nem } \\
\text { Discordo } \\
(\%)\end{array}$ & $\begin{array}{c}\text { Concordo } \\
(\%)\end{array}$ & $\begin{array}{c}\text { Concordo } \\
\text { Totalmente } \\
(\%)\end{array}$ \\
\hline $\begin{array}{c}\text { Cabine de } \\
\text { aplicação de } \\
\text { tintas, vernizes } \\
\text { e tapa poros } \\
\text { Lixagem }\end{array}$ & 0,7 & 5,0 & 4,3 & 23,7 & 1,4 & 4,3 & 0,0 \\
Apoio & 5,0 & 6,5 & 6,5 & 22,3 & 1,4 & 0,0 & 0,0 \\
Outro & 1,4 & 0,7 & 3,6 & 7,9 & 0,0 & 0,0 & 0,7 \\
Total & 0,7 & 0,0 & 2,2 & 1,4 & 0,0 & 0,0 & 0,0 \\
\hline \hline
\end{tabular}


Tabela 103 - Respostas Sobre a Afirmação: "A exposição às tintas/velaturas, vernizes e tapa poros causa-me vómitos"

\begin{tabular}{c|ccccccc}
\hline \hline & $\begin{array}{c}\text { Não } \\
\text { aplicável } \\
(\%)\end{array}$ & $\begin{array}{c}\text { Sem } \\
\text { opinião } \\
(\%)\end{array}$ & $\begin{array}{c}\text { Discordo } \\
\text { Totalmente } \\
(\%)\end{array}$ & $\begin{array}{c}\text { Discordo } \\
(\%)\end{array}$ & $\begin{array}{c}\text { Nem } \\
\text { concordo, } \\
\text { nem } \\
\text { Discordo } \\
(\%)\end{array}$ & $\begin{array}{c}\text { Concordo } \\
(\%)\end{array}$ & $\begin{array}{c}\text { Concordo } \\
\text { Totalmente } \\
(\%)\end{array}$ \\
\hline $\begin{array}{c}\text { Cabine de } \\
\text { aplicação de } \\
\text { tintas, vernizes } \\
\text { e tapa poros } \\
\text { Lixagem }\end{array}$ & 0,7 & 5,0 & 5,0 & 23,0 & 1,4 & 4,3 & 0,0 \\
$\begin{array}{c}\text { Apoio } \\
\text { Outro }\end{array}$ & 1,4 & 2,9 & 1,4 & 7,9 & 0,0 & 0,0 & 1,4 \\
Total & 0,7 & 0,0 & 2,2 & 1,4 & 0,0 & 0,0 & 0,0 \\
\hline \hline
\end{tabular}

Tabela 104 - Respostas Sobre a Afirmação: “Já tive vertigens/tonturas no meu posto de trabalho"

\begin{tabular}{c|ccccccc}
\hline & $\begin{array}{c}\text { Não } \\
\text { aplicável } \\
(\%)\end{array}$ & $\begin{array}{c}\text { Sem } \\
\text { opinião } \\
(\%)\end{array}$ & $\begin{array}{c}\text { Discordo } \\
\text { Totalmente } \\
(\%)\end{array}$ & $\begin{array}{c}\text { Discordo } \\
(\%)\end{array}$ & $\begin{array}{c}\text { Nem } \\
\text { concordo, } \\
\text { nem } \\
\text { Discordo } \\
(\%)\end{array}$ & $\begin{array}{c}\text { Concordo } \\
(\%)\end{array}$ & $\begin{array}{c}\text { Concordo } \\
\text { Totalmente } \\
(\%)\end{array}$ \\
\hline $\begin{array}{c}\text { Cabine de } \\
\text { aplicação de } \\
\text { tintas, vernizes } \\
\text { e tapa poros } \\
\text { Lixagem }\end{array}$ & 0,7 & 3,6 & 3,6 & 19,0 & 3,6 & 8,8 & 0,7 \\
Apoio & 6,6 & 4,4 & 5,8 & 16,1 & 2,2 & 3,6 & 2,2 \\
Outro & 2,2 & 1,5 & 1,5 & 6,6 & 0,7 & 1,5 & 0,7 \\
Total & 0,0 & 0,0 & 2,2 & 1,5 & 0,0 & 0,7 & 0,0 \\
\hline \hline
\end{tabular}


Tabela 105 - Respostas Sobre a Afirmação: “A exposição às tintas/velaturas, vernizes e tapa poros causa-me vertigens/tonturas"

\begin{tabular}{c|ccccccc}
\hline \hline & $\begin{array}{c}\text { Não } \\
\text { aplicável } \\
(\%)\end{array}$ & $\begin{array}{c}\text { Sem } \\
\text { opinião } \\
(\%)\end{array}$ & $\begin{array}{c}\text { Discordo } \\
\text { Totalmente } \\
(\%)\end{array}$ & $\begin{array}{c}\text { Discordo } \\
(\%)\end{array}$ & $\begin{array}{c}\text { Nem } \\
\text { concordo, } \\
\text { nem } \\
\text { Discordo } \\
(\%)\end{array}$ & $\begin{array}{c}\text { Concordo } \\
(\%)\end{array}$ & $\begin{array}{c}\text { Concordo } \\
\text { Totalmente } \\
(\%)\end{array}$ \\
\hline $\begin{array}{c}\text { Cabine de } \\
\text { aplicação de } \\
\text { tintas, vernizes } \\
\text { e tapa poros } \\
\text { Lixagem }\end{array}$ & 0,7 & 2,9 & 4,3 & 21,0 & 5,1 & 5,1 & 0,7 \\
$\begin{array}{c}\text { Apoio } \\
\text { Outro }\end{array}$ & 10,1 & 5,1 & 5,8 & 14,5 & 1,4 & 2,9 & 0,7 \\
Total & 2,2 & 2,2 & 0,7 & 6,5 & 0,7 & 2,2 & 0,7 \\
\hline \hline
\end{tabular}

Tabela 106 - Respostas Sobre a Afirmação: "Quando não utilizo luvas e estou a utilizar as tintas/velaturas, vernizes e tapa poros fico com a pele seca e irritada"

\begin{tabular}{c|ccccccc}
\hline & $\begin{array}{c}\text { Não } \\
\text { aplicável } \\
(\%)\end{array}$ & $\begin{array}{c}\text { Sem } \\
\text { opinião } \\
(\%)\end{array}$ & $\begin{array}{c}\text { Discordo } \\
\text { Totalmente } \\
(\%)\end{array}$ & $\begin{array}{c}\text { Discordo } \\
(\%)\end{array}$ & $\begin{array}{c}\text { Nem } \\
\text { concordo, } \\
\text { nem } \\
\text { Discordo } \\
(\%)\end{array}$ & $\begin{array}{c}\text { Concordo } \\
(\%)\end{array}$ & $\begin{array}{c}\text { Concordo } \\
\text { Totalmente } \\
(\%)\end{array}$ \\
\hline $\begin{array}{c}\text { Cabine de } \\
\text { aplicação de } \\
\text { tintas, vernizes } \\
\text { e tapa poros } \\
\text { Lixagem }\end{array}$ & 2,1 & 0,7 & 0,7 & 5,0 & 5,7 & 19,3 & 6,4 \\
Apoio & 10,7 & 5,0 & 2,9 & 6,4 & 0,7 & 10,7 & 4,3 \\
Outro & 2,9 & 2,1 & 0,0 & 1,4 & 0,7 & 7,1 & 1,4 \\
Total & 0,7 & 0,0 & 0,0 & 0,7 & 0,7 & 2,1 & 0,7 \\
\hline \hline
\end{tabular}


Tabela 107 - Respostas Sobre a Afirmação: "A minha perceção/sensibilidade aos cheiros diminuiu desde que fiquei exposto às tintas/velaturas, vernizes e tapa poros"

\begin{tabular}{c|ccccccc}
\hline \hline & $\begin{array}{c}\text { Não } \\
\text { aplicável } \\
(\%)\end{array}$ & $\begin{array}{c}\text { Sem } \\
\text { opinião } \\
(\%)\end{array}$ & $\begin{array}{c}\text { Discordo } \\
\text { Totalmente } \\
(\%)\end{array}$ & $\begin{array}{c}\text { Discordo } \\
(\%)\end{array}$ & $\begin{array}{c}\text { Nom } \\
\text { concordo, } \\
\text { nem } \\
\text { Discordo } \\
(\%)\end{array}$ & $\begin{array}{c}\text { Concordo } \\
(\%)\end{array}$ & $\begin{array}{c}\text { Concordo } \\
\text { Totalmente } \\
(\%)\end{array}$ \\
\hline $\begin{array}{c}\text { Cabine de } \\
\text { aplicação de } \\
\text { tintas, vernizes } \\
\text { e tapa poros } \\
\text { Lixagem }\end{array}$ & 0,0 & 2,1 & 2,8 & 18,4 & 10,6 & 4,3 & 1,4 \\
Apoio & 9,2 & 7,8 & 3,5 & 11,3 & 2,1 & 4,3 & 2,8 \\
Outro & 1,4 & 2,8 & 0,0 & 5,0 & 2,8 & 1,4 & 1,4 \\
Total & 0,7 & 0,0 & 0,7 & 1,4 & 0,7 & 0,0 & 0,7 \\
\hline \hline
\end{tabular}




\subsection{Interferência do posto de trabalho na exposição}

Tabela 108 - Respostas Sobre a Afirmação: "Ritmo de trabalho muito intenso"

\begin{tabular}{c|ccccccc}
\hline \hline & $\begin{array}{c}\text { Não } \\
\text { aplicável } \\
(\%)\end{array}$ & $\begin{array}{c}\text { Sem } \\
\text { opinião } \\
(\%)\end{array}$ & $\begin{array}{c}\text { Nunca } \\
(\%)\end{array}$ & $\begin{array}{c}\text { Raramente } \\
(\%)\end{array}$ & $\begin{array}{c}\text { Algumas } \\
\text { Vezes } \\
(\%)\end{array}$ & $\begin{array}{c}\text { Maioria } \\
\text { das Vezes } \\
(\%)\end{array}$ & $\begin{array}{c}\text { Sempre } \\
(\%)\end{array}$ \\
\hline $\begin{array}{c}\text { Cabine de } \\
\text { aplicação de } \\
\text { tintas, vernizes } \\
\text { e tapa poros }\end{array}$ & 0,0 & 0,7 & 0,0 & 4,3 & 27,4 & 5,1 & 1,4 \\
$\quad$ Lixagem & 0,0 & 0,7 & 0,0 & 4,3 & 29,5 & 2,2 & 5,0 \\
Apoio & 0,0 & 0,0 & 0,0 & 2,2 & 7,2 & 4,3 & 1,4 \\
Outro & 0,0 & 0,0 & 0,0 & 0,7 & 2,9 & 0,0 & 0,7 \\
Total & 0,0 & 1,4 & 0,0 & 11,5 & 67,0 & 11,6 & 8,5 \\
\hline \hline
\end{tabular}


Tabela 109 - Respostas Sobre a Afirmação: "Por vezes noto muito cheiro aos produtos químicos"

\begin{tabular}{c|ccccccc}
\hline \hline & $\begin{array}{c}\text { Não } \\
\text { aplicável } \\
(\%)\end{array}$ & $\begin{array}{c}\text { Sem } \\
\text { opinião } \\
(\%)\end{array}$ & $\begin{array}{c}\text { Nunca } \\
(\%)\end{array}$ & $\begin{array}{c}\text { Raramente } \\
(\%)\end{array}$ & $\begin{array}{c}\text { Algumas } \\
\text { Vezes } \\
(\%)\end{array}$ & $\begin{array}{c}\text { Maioria } \\
\text { das Vezes } \\
(\%)\end{array}$ & $\begin{array}{c}\text { Sempre } \\
(\%)\end{array}$ \\
\hline $\begin{array}{c}\text { Cabine de } \\
\text { aplicação de } \\
\text { tintas, vernizes } \\
\text { e tapa poros }\end{array}$ & 0,0 & 0,7 & 0,0 & 10,1 & 18,0 & 6,6 & 3,6 \\
Lixagem & 0,7 & 3,6 & 2,9 & 10,8 & 15,1 & 5,0 & 3,6 \\
Apoio & 0,0 & 0,0 & 0,0 & 4,3 & 7,9 & 0,7 & 2,2 \\
Outro & 0,0 & 0,0 & 0,0 & 1,4 & 1,4 & 1,4 & 0,0 \\
Total & 0,7 & 4,3 & 2,9 & 26,6 & 42,4 & 13,7 & 9,4 \\
\hline \hline
\end{tabular}

Tabela 110 - Respostas Sobre a Afirmação: "Às vezes os recipientes vazios das tintas/velaturas, vernizes e tapa poros não são retirados imediatamente dos postos de trabalho"

\begin{tabular}{|c|c|c|c|c|c|c|c|}
\hline & \begin{tabular}{|c} 
Não \\
aplicável \\
$(\%)$
\end{tabular} & $\begin{array}{c}\text { Sem } \\
\text { opinião } \\
(\%)\end{array}$ & $\begin{array}{c}\text { Nunca } \\
(\%)\end{array}$ & $\begin{array}{c}\text { Raramente } \\
(\%)\end{array}$ & $\begin{array}{c}\text { Algumas } \\
\text { Vezes } \\
(\%)\end{array}$ & $\begin{array}{c}\text { Maioria } \\
\text { das Vezes } \\
(\%)\end{array}$ & $\begin{array}{c}\text { Sempre } \\
(\%)\end{array}$ \\
\hline $\begin{array}{c}\text { Cabine de } \\
\text { aplicação de } \\
\text { tintas, vernizes } \\
\text { e tapa poros }\end{array}$ & 1,5 & 1,5 & 4,4 & 13,9 & 10,2 & 3,6 & 3,0 \\
\hline Lixagem & 12,4 & 9,5 & 2,9 & 4,4 & 5,1 & 4,4 & 3,6 \\
\hline Apoio & 0,7 & 3,6 & 1,5 & 3,6 & 1,5 & 1,5 & 2,9 \\
\hline Outro & 0,0 & 0,0 & 0,7 & 0,7 & 0,7 & 1,5 & 0,7 \\
\hline Total & 14,6 & 14,6 & 9,5 & 22,6 & 17,5 & 11,0 & 10,2 \\
\hline
\end{tabular}


Tabela 111 - Respostas Sobre a Afirmação: "Estou satisfeito com o funcionamento das cabines de aspiração"

\begin{tabular}{c|ccccccc}
\hline \hline & $\begin{array}{c}\text { Não } \\
\text { aplicável } \\
(\%)\end{array}$ & $\begin{array}{c}\text { Sem } \\
\text { opinião } \\
(\%)\end{array}$ & $\begin{array}{c}\text { Nunca } \\
(\%)\end{array}$ & $\begin{array}{c}\text { Raramente } \\
(\%)\end{array}$ & $\begin{array}{c}\text { Algumas } \\
\text { Vezes } \\
(\%)\end{array}$ & $\begin{array}{c}\text { Maioria } \\
\text { das Vezes } \\
(\%)\end{array}$ & $\begin{array}{c}\text { Sempre } \\
(\%)\end{array}$ \\
\hline $\begin{array}{c}\text { Cabine de } \\
\text { aplicação de } \\
\text { tintas, vernizes } \\
\text { e tapa poros }\end{array}$ & 0,7 & 0,7 & 1,4 & 2,2 & 9,4 & 10,8 & 13,7 \\
Lixagem & 4,3 & 7,2 & 3,6 & 4,3 & 5,0 & 10,8 & 6,5 \\
Apoio & 0,7 & 2,2 & 1,4 & 0,7 & 2,2 & 3,6 & 4,3 \\
Outro & 0,0 & 0,0 & 0,0 & 0,7 & 0,7 & 0,7 & 2,2 \\
Total & 5,7 & 10,1 & 6,4 & 7,9 & 17,3 & 25,9 & 26,7 \\
\hline \hline
\end{tabular}

Tabela 112 - Respostas Sobre a Afirmação: "Acho que as cabines de aspiração têm a manutenção adequada"

\begin{tabular}{|c|c|c|c|c|c|c|c|}
\hline & $\begin{array}{c}\text { Não } \\
\text { aplicável } \\
(\%)\end{array}$ & $\begin{array}{c}\text { Sem } \\
\text { opinião } \\
(\%)\end{array}$ & $\begin{array}{c}\text { Nunca } \\
(\%)\end{array}$ & $\begin{array}{c}\text { Raramente } \\
(\%)\end{array}$ & $\begin{array}{c}\text { Algumas } \\
\text { Vezes } \\
(\%)\end{array}$ & $\begin{array}{c}\text { Maioria } \\
\text { das Vezes } \\
(\%)\end{array}$ & $\begin{array}{c}\text { Sempre } \\
(\%)\end{array}$ \\
\hline $\begin{array}{c}\text { Cabine de } \\
\text { aplicação de } \\
\text { tintas, vernizes } \\
\text { e tapa poros }\end{array}$ & 2,2 & 1,4 & 0,7 & 4,3 & 10,2 & 9,4 & 10,8 \\
\hline Lixagem & 6,5 & 10,8 & 1,4 & 5,0 & 2,2 & 9,4 & 6,5 \\
\hline Apoio & 0,7 & 2,9 & 0,7 & 1,4 & 2,2 & 0,7 & 6,5 \\
\hline Outro & 0,0 & 0,7 & 0,0 & 0,0 & 1,4 & 0,7 & 1,4 \\
\hline Total & 9,4 & 15,8 & 2,8 & 10,7 & 16,0 & 20,1 & 25,2 \\
\hline
\end{tabular}


Tabela 113 - Respostas Sobre a Afirmação: "É possível diminuir a exposição às tintas/velaturas, vernizes e tapa poros"

\begin{tabular}{c|ccccccc}
\hline \hline & $\begin{array}{c}\text { Não } \\
\text { aplicável } \\
(\%)\end{array}$ & $\begin{array}{c}\text { Sem } \\
\text { opinião } \\
(\%)\end{array}$ & $\begin{array}{c}\text { Nunca } \\
(\%)\end{array}$ & $\begin{array}{c}\text { Raramente } \\
(\%)\end{array}$ & $\begin{array}{c}\text { Algumas } \\
\text { Vezes } \\
(\%)\end{array}$ & $\begin{array}{c}\text { Maioria } \\
\text { das Vezes } \\
(\%)\end{array}$ & $\begin{array}{c}\text { Sempre } \\
(\%)\end{array}$ \\
\hline $\begin{array}{c}\text { Cabine de } \\
\text { aplicação de } \\
\text { tintas, vernizes } \\
\text { e tapa poros } \\
\text { Lixagem }\end{array}$ & 0,7 & 10,3 & 5,2 & 6,6 & 10,3 & 4,4 & 1,5 \\
Apoio & 9,6 & 19,1 & 1,5 & 1,5 & 4,4 & 2,9 & 2,9 \\
Outro & 0,0 & 7,4 & 0,0 & 0,0 & 2,9 & 1,5 & 2,9 \\
Total & 0,0 & 0,7 & 0,7 & 0,0 & 1,5 & 0,0 & 1,5 \\
\hline \hline
\end{tabular}

Tabela 114 - Respostas Sobre a Afirmação: "É possível diminuir a exposição aos cheiros das tintas/velaturas, vernizes e tapa poros"

\begin{tabular}{c|ccccccc}
\hline \hline & $\begin{array}{c}\text { Não } \\
\text { aplicável } \\
(\%)\end{array}$ & $\begin{array}{c}\text { Sem } \\
\text { opinião } \\
(\%)\end{array}$ & $\begin{array}{c}\text { Nunca } \\
(\%)\end{array}$ & $\begin{array}{c}\text { Raramente } \\
(\%)\end{array}$ & $\begin{array}{c}\text { Algumas } \\
\text { Vezes } \\
(\%)\end{array}$ & $\begin{array}{c}\text { Maioria } \\
\text { das Vezes } \\
(\%)\end{array}$ & $\begin{array}{c}\text { Sempre } \\
(\%)\end{array}$ \\
\hline $\begin{array}{c}\text { Cabine de } \\
\text { aplicação de } \\
\text { tintas, vernizes } \\
\text { e tapa poros }\end{array}$ & 0,7 & 10,1 & 5,8 & 7,9 & 8,6 & 4,3 & 1,4 \\
Lixagem & 9,4 & 18,0 & 1,4 & 2,9 & 6,5 & 1,4 & 2,2 \\
Apoio & 0,0 & 6,5 & 0,7 & 0,7 & 2,2 & 2,2 & 2,9 \\
Outro & 0,0 & 0,7 & 1,4 & 0,0 & 0,7 & 0,0 & 1,4 \\
Total & 10,1 & 35,3 & 9,3 & 11,5 & 18,0 & 7,9 & 7,9 \\
\hline \hline
\end{tabular}


Tabela 115 - Respostas Sobre a Afirmação: "Existe preocupação da empresa em diminuir a exposição às tintas/velaturas, vernizes e tapa poros"

\begin{tabular}{c|ccccccc}
\hline \hline & $\begin{array}{c}\text { Não } \\
\text { aplicável } \\
(\%)\end{array}$ & $\begin{array}{c}\text { Sem } \\
\text { opinião } \\
(\%)\end{array}$ & $\begin{array}{c}\text { Nunca } \\
(\%)\end{array}$ & $\begin{array}{c}\text { Raramente } \\
(\%)\end{array}$ & $\begin{array}{c}\text { Algumas } \\
\text { Vezes } \\
(\%)\end{array}$ & $\begin{array}{c}\text { Maioria } \\
\text { das Vezes } \\
(\%)\end{array}$ & $\begin{array}{c}\text { Sempre } \\
(\%)\end{array}$ \\
\hline $\begin{array}{c}\text { Cabine de } \\
\text { aplicação de } \\
\text { tintas, vernizes } \\
\text { e tapa poros } \\
\text { Lixagem }\end{array}$ & 0,7 & 7,2 & 0,7 & 4,3 & 7,9 & 8,6 & 9,4 \\
Apoio & 5,1 & 13,0 & 0,7 & 1,4 & 6,6 & 4,3 & 10,8 \\
Outro & 0,0 & 5,0 & 0,7 & 1,4 & 2,9 & 0,7 & 4,3 \\
Total & 0,0 & 0,0 & 0,0 & 0,7 & 0,0 & 0,7 & 2,9 \\
\hline \hline
\end{tabular}




\subsection{Frequência de atitudes preventivas}

Tabela 116 - Respostas Sobre a Afirmação: "Não cumprir as regras de segurança"

\begin{tabular}{c|ccccccc}
\hline \hline & $\begin{array}{c}\text { Não } \\
\text { aplicável } \\
(\%)\end{array}$ & $\begin{array}{c}\text { Sem } \\
\text { opinião } \\
(\%)\end{array}$ & $\begin{array}{c}\text { Nunca } \\
(\%)\end{array}$ & $\begin{array}{c}\text { Raramente } \\
(\%)\end{array}$ & $\begin{array}{c}\text { Algumas } \\
\text { Vezes } \\
(\%)\end{array}$ & $\begin{array}{c}\text { Maioria } \\
\text { das Vezes } \\
(\%)\end{array}$ & $\begin{array}{c}\text { Sempre } \\
(\%)\end{array}$ \\
\hline $\begin{array}{c}\text { Cabine de } \\
\text { aplicação de } \\
\text { tintas, vernizes } \\
\text { e tapa poros }\end{array}$ & 0,7 & 4,3 & 13,6 & 12,1 & 4,3 & 2,1 & 2,9 \\
$\quad$ Lixagem & 0,0 & 4,3 & 12,9 & 9,3 & 7,9 & 2,9 & 3,6 \\
Apoio & 0,7 & 1,4 & 4,3 & 2,1 & 2,1 & 0,7 & 3,6 \\
Outro & 0,7 & 0,0 & 0,7 & 0,7 & 1,4 & 0,0 & 0,7 \\
Total & 2,1 & 10,0 & 31,5 & 24,2 & 15,7 & 5,7 & 10,8 \\
\hline \hline
\end{tabular}


Tabela 117 - Respostas Sobre a Afirmação: "Executar as atividades de acordo com as instruções de trabalho"

\begin{tabular}{c|ccccccc}
\hline \hline & $\begin{array}{c}\text { Não } \\
\text { aplicável } \\
(\%)\end{array}$ & $\begin{array}{c}\text { Sem } \\
\text { opinião } \\
(\%)\end{array}$ & $\begin{array}{c}\text { Nunca } \\
(\%)\end{array}$ & $\begin{array}{c}\text { Raramente } \\
(\%)\end{array}$ & $\begin{array}{c}\text { Algumas } \\
\text { Vezes } \\
(\%)\end{array}$ & $\begin{array}{c}\text { Maioria } \\
\text { das Vezes } \\
(\%)\end{array}$ & $\begin{array}{c}\text { Sempre } \\
(\%)\end{array}$ \\
\hline $\begin{array}{c}\text { Cabine de } \\
\text { aplicação de } \\
\text { tintas, vernizes } \\
\text { e tapa poros }\end{array}$ & 0,0 & 2,1 & 0,0 & 1,4 & 4,9 & 12,0 & 19,0 \\
Lixagem & 0,0 & 3,5 & 0,0 & 0,0 & 6,3 & 10,6 & 21,0 \\
Apoio & 0,0 & 1,4 & 0,0 & 0,7 & 1,4 & 3,5 & 7,7 \\
Outro & 0,0 & 0,0 & 0,0 & 0,7 & 0,0 & 0,7 & 2,8 \\
Total & 0,0 & 7,0 & 0,0 & 2,8 & 12,6 & 26,8 & 50,8 \\
\hline \hline
\end{tabular}

Tabela 118 - Respostas Sobre a Afirmação: "Executar as atividades de acordo com o que a empresa me ensinou"

\begin{tabular}{|c|c|c|c|c|c|c|c|}
\hline & $\begin{array}{c}\text { Não } \\
\text { aplicável } \\
(\%)\end{array}$ & $\begin{array}{c}\text { Sem } \\
\text { opinião } \\
(\%)\end{array}$ & $\begin{array}{c}\text { Nunca } \\
(\%)\end{array}$ & $\begin{array}{c}\text { Raramente } \\
(\%)\end{array}$ & $\begin{array}{c}\text { Algumas } \\
\text { Vezes } \\
(\%)\end{array}$ & $\begin{array}{c}\text { Maioria } \\
\text { das Vezes } \\
(\%)\end{array}$ & $\begin{array}{c}\text { Sempre } \\
(\%)\end{array}$ \\
\hline $\begin{array}{c}\text { Cabine de } \\
\text { aplicação de } \\
\text { tintas, vernizes } \\
\text { e tapa poros }\end{array}$ & 0,0 & 2,9 & 0,0 & 1,4 & 3,5 & 10,6 & 21,3 \\
\hline Lixagem & 0,0 & 2,1 & 0,0 & 0,7 & 5,0 & 9,3 & 24,1 \\
\hline Apoio & 0,0 & 0,0 & 0,0 & 0,0 & 0,7 & 6,4 & 7,8 \\
\hline Outro & 0,0 & 0,0 & 0,0 & 0,0 & 0,0 & 0,7 & 3,5 \\
\hline Total & 0,0 & 5,0 & 0,0 & 2,1 & 9,2 & 27,0 & 56,7 \\
\hline
\end{tabular}


Tabela 119 - Respostas Sobre a Afirmação: "Usar sempre luvas na manipulação das tintas/velaturas,

vernizes e tapa poros"

\begin{tabular}{c|ccccccc}
\hline \hline & $\begin{array}{c}\text { Não } \\
\text { aplicável } \\
(\%)\end{array}$ & $\begin{array}{c}\text { Sem } \\
\text { opinião } \\
(\%)\end{array}$ & $\begin{array}{c}\text { Nunca } \\
(\%)\end{array}$ & $\begin{array}{c}\text { Raramente } \\
(\%)\end{array}$ & $\begin{array}{c}\text { Algumas } \\
\text { Vezes } \\
(\%)\end{array}$ & $\begin{array}{c}\text { Maioria } \\
\text { das Vezes } \\
(\%)\end{array}$ & $\begin{array}{c}\text { Sempre } \\
(\%)\end{array}$ \\
\hline $\begin{array}{c}\text { Cabine de } \\
\text { aplicação de } \\
\text { tintas, vernizes } \\
\text { e tapa poros } \\
\text { Lixagem }\end{array}$ & 0,7 & 0,0 & 0,0 & 0,0 & 0,7 & 10,0 & 28,8 \\
Apoio & 11,6 & 2,1 & 0,7 & 0,7 & 2,1 & 4,3 & 19,3 \\
Outro & 1,4 & 0,0 & 0,0 & 0,0 & 1,4 & 2,1 & 10,0 \\
Total & 0,7 & 0,0 & 0,0 & 0,0 & 0,0 & 0,7 & 2,9 \\
\hline \hline
\end{tabular}

Tabela 120 - Respostas Sobre a Afirmação: "Usar sempre avental na manipulação das tintas/velaturas, vernizes e tapa poros"

\begin{tabular}{c|ccccccc}
\hline \hline & $\begin{array}{c}\text { Não } \\
\text { aplicável } \\
(\%)\end{array}$ & $\begin{array}{c}\text { Sem } \\
\text { opinião } \\
(\%)\end{array}$ & $\begin{array}{c}\text { Nunca } \\
(\%)\end{array}$ & $\begin{array}{c}\text { Raramente } \\
(\%)\end{array}$ & $\begin{array}{c}\text { Algumas } \\
\text { Vezes } \\
(\%)\end{array}$ & $\begin{array}{c}\text { Maioria } \\
\text { das Vezes } \\
(\%)\end{array}$ & $\begin{array}{c}\text { Sempre } \\
(\%)\end{array}$ \\
\hline $\begin{array}{c}\text { Cabine de } \\
\text { aplicação de } \\
\text { tintas, vernizes } \\
\text { e tapa poros }\end{array}$ & 7,9 & 3,6 & 3,6 & 2,1 & 1,4 & 5,1 & 15,8 \\
Lixagem & 21,4 & 5,1 & 2,1 & 1,4 & 2,1 & 0,7 & 8,6 \\
Apoio & 2,9 & 1,4 & 2,1 & 0,0 & 1,4 & 0,7 & 6,4 \\
Outro & 0,7 & 0,0 & 0,7 & 0,0 & 0,0 & 0,7 & 2,1 \\
Total & 32,9 & 10,1 & 8,5 & 3,5 & 4,9 & 7,2 & 32,9 \\
\hline \hline
\end{tabular}


Tabela 121 - Respostas Sobre a Afirmação: "Usar sempre fato de proteção na manipulação das tintas/velaturas, vernizes e tapa poros"

\begin{tabular}{c|ccccccc}
\hline \hline & $\begin{array}{c}\text { Não } \\
\text { aplicável } \\
(\%)\end{array}$ & $\begin{array}{c}\text { Sem } \\
\text { opinião } \\
(\%)\end{array}$ & $\begin{array}{c}\text { Nunca } \\
(\%)\end{array}$ & $\begin{array}{c}\text { Raramente } \\
(\%)\end{array}$ & $\begin{array}{c}\text { Algumas } \\
\text { Vezes } \\
(\%)\end{array}$ & $\begin{array}{c}\text { Maioria } \\
\text { das Vezes } \\
(\%)\end{array}$ & $\begin{array}{c}\text { Sempre } \\
(\%)\end{array}$ \\
\hline $\begin{array}{c}\text { Cabine de } \\
\text { aplicação de } \\
\text { tintas, vernizes } \\
\text { e tapa poros }\end{array}$ & 5,8 & 3,6 & 3,6 & 1,4 & 1,4 & 5,8 & 17,4 \\
Lixagem & 22,3 & 4,3 & 1,4 & 0,0 & 2,9 & 2,2 & 8,6 \\
Apoio & 3,6 & 2,9 & 0,7 & 0,0 & 0,0 & 1,4 & 6,5 \\
Outro & 1,4 & 0,0 & 0,7 & 0,0 & 0,0 & 0,7 & 1,4 \\
Total & 33,1 & 10,8 & 6,4 & 1,4 & 4,3 & 10,1 & 33,9 \\
\hline \hline
\end{tabular}

Tabela 122 - Respostas Sobre a Afirmação: “Usar sempre máscara de proteção na manipulação das tintas/velaturas, vernizes e tapa poros"

\begin{tabular}{|c|c|c|c|c|c|c|c|}
\hline & \begin{tabular}{|c} 
Não \\
aplicável \\
$(\%)$
\end{tabular} & $\begin{array}{c}\text { Sem } \\
\text { opinião } \\
(\%)\end{array}$ & $\begin{array}{c}\text { Nunca } \\
(\%)\end{array}$ & $\begin{array}{c}\text { Raramente } \\
\text { (\%) }\end{array}$ & $\begin{array}{c}\text { Algumas } \\
\text { Vezes } \\
(\%)\end{array}$ & $\begin{array}{c}\text { Maioria } \\
\text { das Vezes } \\
(\%)\end{array}$ & $\begin{array}{c}\text { Sempre } \\
(\%)\end{array}$ \\
\hline $\begin{array}{c}\text { Cabine de } \\
\text { aplicação de } \\
\text { tintas, vernizes } \\
\text { e tapa poros }\end{array}$ & 2,1 & 0,7 & 0,0 & 0,0 & 2,1 & 8,5 & 26,0 \\
\hline Lixagem & 17,6 & 2,8 & 0,7 & 0,0 & 3,6 & 2,8 & 14,1 \\
\hline Apoio & 2,1 & 0,7 & 0,0 & 0,0 & 2,1 & 1,4 & 8,5 \\
\hline Outro & 0,7 & 0,0 & 0,0 & 0,0 & 0,7 & 0,7 & 2,1 \\
\hline Total & 22,5 & 4,2 & 0,7 & 0,0 & 8,5 & 13,4 & 50,7 \\
\hline
\end{tabular}




\subsection{Formação em matérias de saúde e segurança no trabalho}

Tabela 123 - Respostas Sobre a Afirmação: “Já tive formação de combate a incêndios"

\begin{tabular}{c|cc}
\hline \hline & $\begin{array}{c}\text { Sim } \\
(\%)\end{array}$ & $\begin{array}{c}\text { Não } \\
(\%)\end{array}$ \\
\hline $\begin{array}{c}\text { Cabine de } \\
\text { aplicação de } \\
\text { tintas, vernizes } \\
\text { e tapa poros } \\
\text { Lixagem }\end{array}$ & 23,9 & 15,9 \\
Apoio & 21,7 & 18,8 \\
Outro & 3,8 & 9,4 \\
Total & 55,1 & 44,9 \\
\hline \hline
\end{tabular}

Tabela 124 - Respostas Sobre a Afirmação: "Já tive formação sobre os riscos dos produtos químicos"

\begin{tabular}{c|cc}
\hline & $\begin{array}{c}\text { Sim } \\
(\%)\end{array}$ & $\begin{array}{c}\text { Não } \\
\text { (\%) }\end{array}$ \\
\hline $\begin{array}{c}\text { Cabine de } \\
\text { aplicação de } \\
\text { tintas, vernizes } \\
\text { e tapa poros } \\
\text { Lixagem }\end{array}$ & 25,9 & 11,9 \\
Apoio & 20,7 & 21,5 \\
Outro & 5,2 & 10,4 \\
Total & 3,0 & 1,5 \\
\hline \hline
\end{tabular}


Tabela 125 - Respostas Sobre a Afirmação: “Já tive formação acerca do manuseamento correto dos produtos químicos"

\begin{tabular}{c|cc}
\hline \hline & $\begin{array}{c}\text { Sim } \\
(\%)\end{array}$ & $\begin{array}{c}\text { Não } \\
(\%)\end{array}$ \\
\hline $\begin{array}{c}\text { Cabine de } \\
\text { aplicação de } \\
\text { tintas, vernizes } \\
\text { e tapa poros } \\
\text { Lixagem }\end{array}$ & 23,9 & 14,2 \\
Apoio & 17,9 & 23,9 \\
Outro & 4,5 & 11,2 \\
Total & 49,3 & 1,5 \\
\hline \hline
\end{tabular}

Tabela 126 - Respostas Sobre a Afirmação: "Já tive formação de como proceder no caso de derrame dos produtos químicos"

\begin{tabular}{c|cc}
\hline \hline & $\begin{array}{c}\text { Sim } \\
(\%)\end{array}$ & $\begin{array}{c}\text { Não } \\
\text { (\%) }\end{array}$ \\
\hline $\begin{array}{c}\text { Cabine de } \\
\text { aplicação de } \\
\text { tintas, vernizes } \\
\text { e tapa poros } \\
\text { Lixagem }\end{array}$ & 23,1 & 15,7 \\
Apoio & 17,2 & 23,9 \\
Outro & 3,7 & 11,9 \\
Total & 2,2 & 2,2 \\
\hline \hline
\end{tabular}


Tabela 127 - Respostas Sobre a Afirmação: “Já tive formação sobre saúde e segurança na aplicação dos produtos químicos"

\begin{tabular}{c|cc}
\hline \hline & $\begin{array}{c}\text { Sim } \\
(\%)\end{array}$ & $\begin{array}{c}\text { Não } \\
(\%)\end{array}$ \\
\hline $\begin{array}{c}\text { Cabine de } \\
\text { aplicação de } \\
\text { tintas, vernizes } \\
\text { e tapa poros } \\
\text { Lixagem }\end{array}$ & 27,9 & 10,3 \\
Apoio & 20,6 & 21,3 \\
Outro & 6,6 & 8,8 \\
Total & 58,9 & 1,5 \\
\hline \hline
\end{tabular}

Tabela 128 - Respostas Sobre a Afirmação: "A última vez que tive formação sobre riscos laborais no meu posto de trabalho"

\begin{tabular}{c|ccccc}
\hline \hline & $\begin{array}{c}\text { Antes de } \\
\mathbf{2 0 1 1} \\
(\%)\end{array}$ & $\begin{array}{c}\mathbf{2 0 1 1} \\
(\%)\end{array}$ & $\begin{array}{c}\mathbf{2 0 1 2} \\
(\%)\end{array}$ & $\begin{array}{c}\mathbf{2 0 1 3} \\
(\%)\end{array}$ & $\begin{array}{c}\mathbf{2 0 1 4} \\
(\%)\end{array}$ \\
\hline $\begin{array}{c}\text { Cabine de } \\
\text { aplicação de } \\
\text { tintas, vernizes } \\
\text { e tapa poros } \\
\text { Lixagem }\end{array}$ & 13,0 & 3,7 & 8,3 & 14,8 & 0,9 \\
Apoio & 10,2 & 3,7 & 8,3 & 18,5 & 2,8 \\
Outro & 3,7 & 0,9 & 0,9 & 6,5 & 0,0 \\
Total & 0,9 & 0,0 & 0,0 & 2,8 & 0,0 \\
\hline \hline
\end{tabular}

